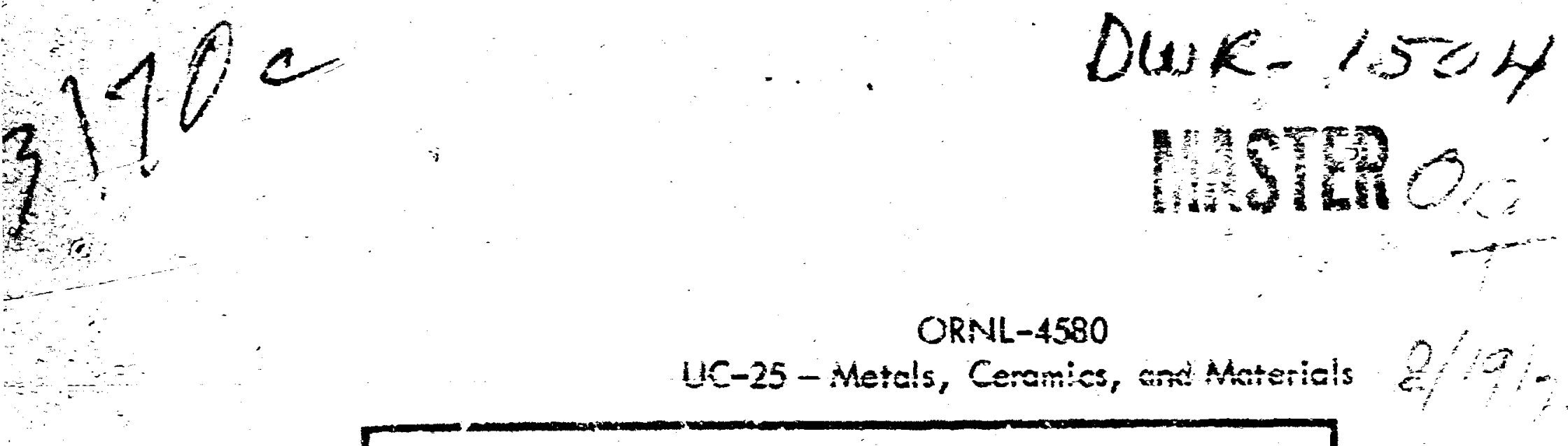




\section{BLANK PAGE}




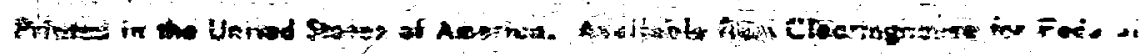

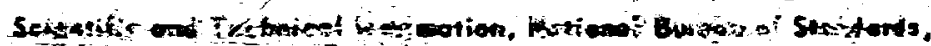

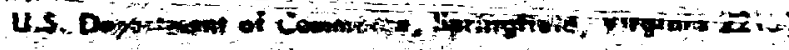

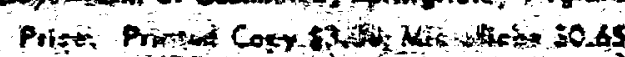

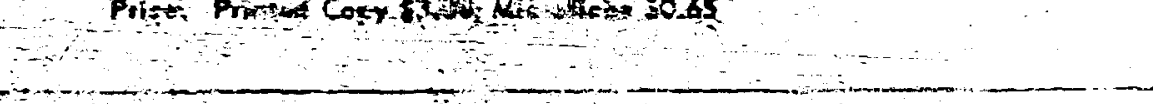

$\therefore-10$

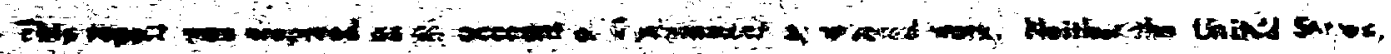

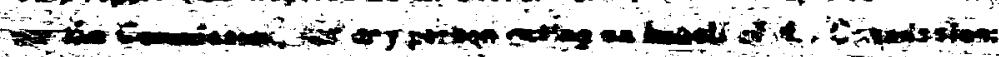

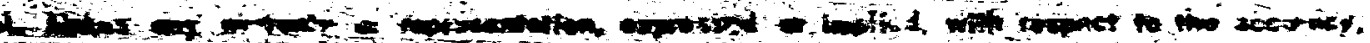

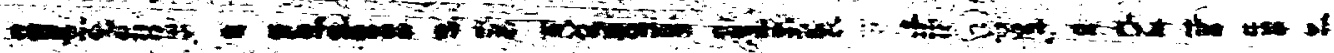

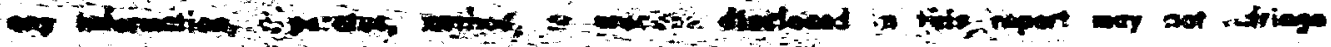
inimaty

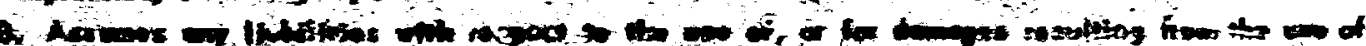

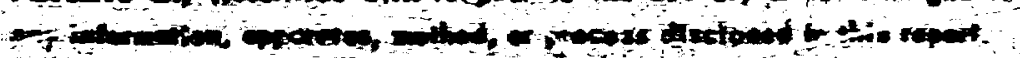

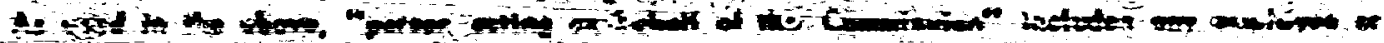

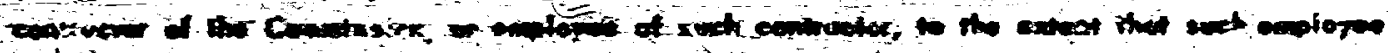

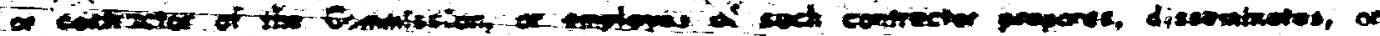

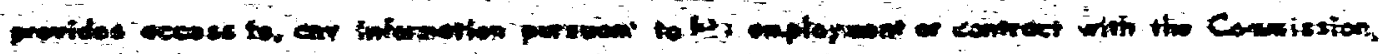
- He soptornot wh soch centrestor. 


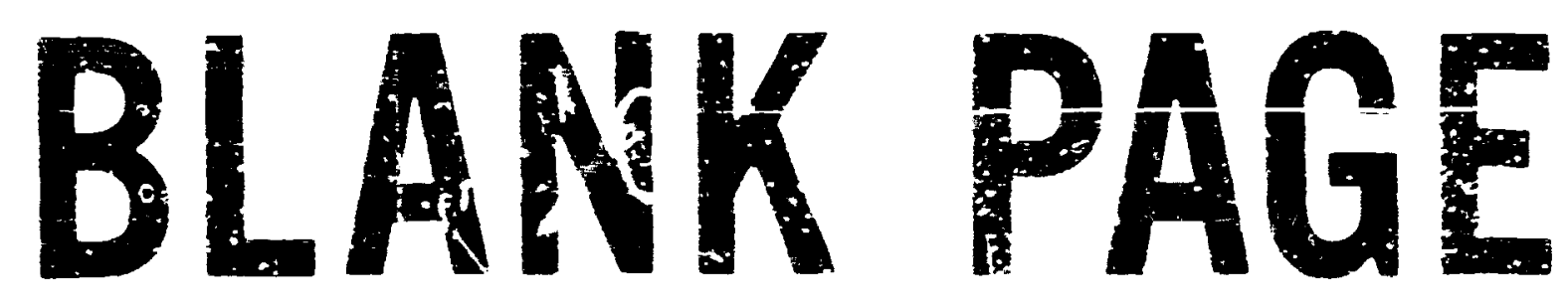


Contract No. W-7405-eng-26

METALS AND CERAMICS DIVISIOK

AN INVESTIGATION OF FAST NEUTRON RADLATION DAMAGE

IN AN AUSTENITIC STAINLESS STEEL

Everett E. Bloos

A dissertation presented to the Grad:ate Cnuncil of The University of Tennessee in partial fulfillment of the requirements for the degree of Dector of Philosophy.

AUGUST 1970

OAR KIDGE RATIONAL LABORATORY

Oak Ridge, Tennessee

operated by

UNION CARBIDE CORPORATION

for the

U.S. ATOMIC ENERGY COMAISEION 


\section{ACKNOWLEDGIENT}

The author expresses his sincerest appreciacion to his major professor, Dr. C. J. McHargue, for his professional guidance, patience and enccuragenent throughout the course of this investigation and during the preparation of this manuscript.

Deepest gratitude is expressed to J. 0. Stiegler and Dr. F. H. Wiffen for their any contributions to the scientific content and Aizastise of the project.

Tnis research was carried out in the Metals and Cerancs Division at Oak Ridge National Laboratory, operated by Union Carbide Cnrporation for the U. S. Atonic Energy Comission. The author is grateful for the opportunity to perform this investigation at the laboratory were the expertise and facilities were avallable. Special appreciation is expressed to J. R. Weir for his continued interest in the author's work, and for his encouragement and professional guidance. Gratitude is also expressed to Dr. H. E. McCoy and Dr. B. T. M. Loh for their many helpfal discussions and suggestions. The author gratefully acknowleriges the assistance given in the various phases of the experimental work by L. C. Rardcn, C. Jones, C. R. H. DuBose and A. A. Walls.

The assistance of Mrs. Rathy Gardner, Mrs. Susan Price, Mrs. Dorna Wiffen and Miss Jane Morrison for typing tse manuscript, and to the Graphic Arts Section of Oak Ridge National Laboratory for preparation of the drawings is appreclated. 
The author would like to express his heartfeit thanks to his wother, Mrs. Ratheryn Bloom, and his father, the late John G. Bloom, for their encouragement and assistance in sbtaining a college education, and to his wife, Carol, for her encouragement during the last five years of part-time graduate work. 


\section{ABSTRACT}

The nature of irradiation damage in type 304 stainiess steel has been deduced from a study of micrnstructure and density of specimens Irradiated by neutrons in the temperature range 370 to $800^{\circ} \mathrm{C}$ to fluences of $1 \times 10^{18}$ to $5 \times 10^{22}$ neutrons $/ \mathrm{cm}^{2}$ (E $>0.1 \mathrm{MeV}$.

No damage was detected at exposures less than $1 \times 10^{18}$ neutrons $/ \mathrm{cm}^{2}$ (E > $0.1 \mathrm{MeV})$. At $1.4 \times 10^{20}$ neutrons $/ \mathrm{cr}^{2}$ (E > $0.1 \mathrm{MeV}$, small defect clusters, which appeared as black dots under suitable diffraction conditions, were present in the microstructure. Most of these smail defect clusters were dislocation loops with Burgers' vectors of the type a/3 (111). A small fraction of the dots exhibited diffraction contrast consistent with either that expected from a/2 1110$\rangle$ dislocation loops or froll defect clusters having spherically symmetric strain fields. The concentration of the swall defect clusters decreased as the irradiation temperature was increased above $370^{\circ} \mathrm{C}$. After irradiation at $524^{\circ} \mathrm{C}$, no defect clusters were observed by transmission electron microscopy, indicating the concentration to be less than about $10^{12}$ defects $/ \mathrm{cm}^{3}$.

Specimens irradiated to fast neutron fluences in the range $2 \times 10^{21}$ to $5 \times 10^{22}$ neutrons $/ \mathrm{cm}^{2}$ (E $\left.>0.1 \mathrm{MeV}\right)$ at 370 to $470^{\circ} \mathrm{C}$ contained voids and faulted interstitial dislocation loops. After irradiation to the lower fluences in this range the damage was heterogeneously distributed. Dislocation loops were clustered around dislocation lines and voids were located on dislocation lines. The vold concentrations were higher at $370-380^{\circ} \mathrm{C}$ than at $460-470^{\circ} \mathrm{C}$ over the entire range of fluence 
investigated. The void concentrations increased as the fluence raised to the 0.66 and 1.66 power at $370-380^{\circ} \mathrm{C}$ and $460-470^{\circ} \mathrm{C}$, respectively. After ir:adiation at $570-630^{\circ} \mathrm{C}$, the damage structure consisted of a dislocation network, a few unfaulted dislocation loops, and voids nearly always associated with the dislocation lines. The only damage observed after irradiation at $7 \bar{T} 0-\overline{8} \dot{4} 0^{\circ} \mathrm{C}$ was helium bubbles which were present both at grain boundaries and within the matrix.

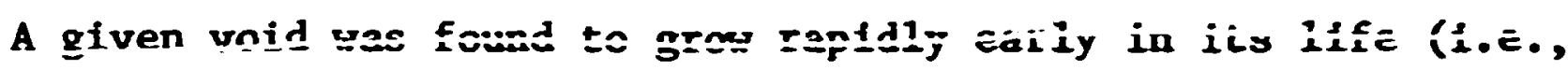
at small void sizes). A short time after its formation (a few times $10^{21}$ neutrons $/ \mathrm{cm}^{2}$ ) the void growth rate decreased sharply. As a result, the density change was closely related to the void nucleation rate.

The microstructures of specimens which contained cyclotron injected helium prior to thelr irradiation showed hellum to have a pronourced influence on vold formation. Specimens preinjected with helium contained a higher concentration of smaller voids.

These observations are consistent with the concept that void nucleation occurs by the stabilization of vold nuclei by the helium produced by $(n, \alpha)$ reactions. At low fluences and thus low helium concentrations, helium collects on dislocations and the first voids appear at these defects. As the helium concentration increases, stable nuclei form in the matrix and give a more uniform void distribution. Helium stabllization of vold nuclei gives a vold nucleation rate whych is initially low, then increases until saturation of the void concentration occurs. Thie decrease in void growth rate is thought to be due to the bufldup of a shell around the void within which the vacancy diffusivity is lower than in the homogeneous alloy. 
TABLE OF CONTENTS

CEAPTER

PAGE

I. INTRCDUCTION ..................... 1

II. NEUTROA IRRADIATION DAMAGE PROCESSES . . . . . . . . 3

Displacement of Atoms in Solids by Neutron Irradiation . 3

Transmutation Reactions ............. 10

III. FORHATION OF DEFECT ClUSTERS . . . . . . . . . . 15

Stabllity of Various Defect Configurations . . . . . 16

Irradiation Damage in Pure Face-Centered Cubic Metals . 18

Irradiation Damage in Austenitic Stainless Steels ... . 23

IV. EXPERIMEATAL PROCEDURE . . . . . . . . . . . . 42

Description of Reactor Components . . . . . . . . 42

Design of Irradiation Experiments . . . . . . . . 52

Fínsmission Electron Mfcroscopy . . . . . . . . 57

Immersion Density Measurements . . . . . . . . 58

Experimental Errors . . . . . . . . . . 60

จ. RESULTS ..................... 63

Trangmission Electron Microscopy Observations . . . . 64

Damage at low neutron fluence ........... . 64

Dislocation loops and networks ......... 69

Volds and swelling .............. 84

Eff zcts of Helium on Irrzdiation Damage . . . . . . 109

Immersiors Density Measurements . . . . . . . . 112 
vI. SUMAARI OF RESULTS AND DISCUSSION . . . . . . . . . . . 122

General observations .............. 122

Irradiation damage at low fluences . . . . . . . 122

Development of dislocation structure ........ 123

Development of vold structure . . . . . . . . 130

Discussion of Results: Nucleation and Growth

Mechanisms ................ 1336

vir. Conclusions . . . . . . . . . . . . . . . . 149

LIST OF REFERENCES . . . . . . . . . . . . . . . . 151

APPENDICES . . . . . . . . . . . . . . . . . . . 161

A. DESCRIPTION OF EXPERIMTATAL BREEDER REACTOR-II . . . . . . 161

B. MEASUREMENT OF घOID CONCERTRATION . . . . . . . . . . 165 


\section{LIST OF TABLES}

TABLE

PAGE

I. Characteristics of Voids In Irradiated Pure Metals . . . 24

II. Compositions of Typical Ualiradiated EBR-II Components . . 44

III. Composition of Type 304 Stainless Steel Used in Ē̄̄K-II Katerials Irradiation Experiments . . . . . . . . 54

IV. Comparison of Void Concentrations in Specimens Irradiated to Approximately the Same Neutron Fluence at Different Neutron Flux Levels................ 107

V. Density Change of Specinens Removed from the EBR-II Safety núd minhle... . . . . . . . . . . . . 114

ri. Density and Density Change is Type 304 Stainless Steel

Irradiated in EBR-II Experimental Subassembiy X0-34 . . 117

VII. Void Concentration D\&:a for Foils 1 and 2 of Irradiated

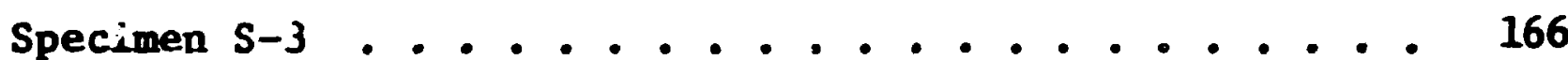




\section{LIST OF FIGURES}

\section{FIGURE}

PAGE

1. Average Number of Atom Displacements as a Punction of Neutron Energy in Iron (Atomic Weight 56) . . . . . . . 7

2. Calculated Hellum Concentration in Type 304 Stainless

Steel as a Function of the Fast Neutron Fluence . . . .

3. Density Decrease in High Purity Nickel (N1 270), Commercially Pure Nickel (N1 200), and a Nickel Base Ailoy

(Inconel 600) as a Result of Neutron Irradiat:on . • : . . 22

4. Type 304 Stainless Steel Irradiated at $93^{\circ} \mathrm{C}$. . . . . . . 25

5. Plate-Like Precipitates Formed in Type 304 Stainless

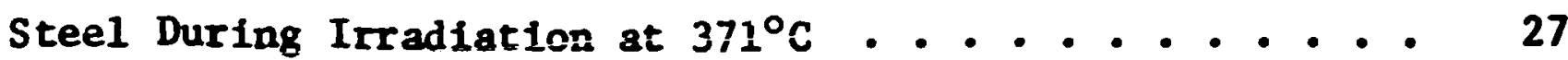

6. Precipitates, with a Denuded Zone Adjacent to the Grain

Boundary, Formed in Type 304 Stainless Stee1 During

Irradiation at $454^{\circ} \mathrm{C}$. . . . . . . . . . . . .

7. Temperature Dependence of the Rates of Void Nucleation and Void Growth in Type 304 Stainless Steel Irradiated in EBR-II as Calculated by the Model of Harkness and L1.

8. Predicted Temperature Dependence of Void Formation from Hodel of Harkness and $\mathrm{LI} . . . . . . . . . . . . . .$.

9. Expected Void Volume as a Function of Temperature and

Fluence from Model of Harkness and Lf. . . . . . . . . 39

10. Microstructure of Unirradiated EBR-II Fuel Cladd: 18 . . . 45

11. MIcrostructure of Unirradiated EER-II Safety Rod ThImble . . 46 
FIGURE

PAGE

12. Irradiation Conditions for EBR-Ii Fuel Cladding . . . . . 47

13. Irradiation Conditions for EBR-II Sh::oud Tube . . . . . 49

14. Irradiation Conditions for EBR-II Safety Rod Thimble . . . 51

15. Drawing of Specimen Used in EBR-II Materiris Irridiation Experlments ................... 53

16. Schenatic Drawing of Specimen Holder Used in EBR-II

Materials Irradiation Experfinents . . . . . . . 55

17. Transmission Electron Mfcrograph Showing Defect Cisters

in Type 304 Stainless Steei Trradiated at $384^{\circ} \mathrm{C}$ to

$1.4=10^{20}$ Neutrons $/ \mathrm{cm}^{2}(\bar{E}>0.1 \mathrm{MeV}) \ldots 65$

18. Concentration of Defect Clusters in Type 304 stafiniess

Steel Irradiated at Temperatures Between 384 and $524^{\circ} \mathrm{C}$

to $1.4 \times 10^{20}$ Neutrons $/ \mathrm{cm}^{2}$ (E $\left.>0.1 \mathrm{MeV}\right) \ldots 66$

19. Small Dot-Like Defects Observed Under Two Beam Diffraction Conditions . . . . . . . . . . . . . . 68

200. Dislocation Loops in Type 304 Stainless Steel Irradiated at $370^{\circ} \mathrm{C}$ to $2.0 \times 10^{21}$ Neutrons $/ \mathrm{cm}^{2}(\mathrm{E}>0.1 \mathrm{MeV})$... 70

21. Disjocation Structure in Specimens Irradiated at

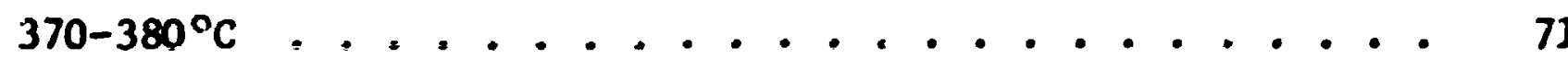

22. Defect Clusters in Type 304 Stainless Steel Irradiated

at $460-470^{\circ} \mathrm{C}$ to $1.4 \times 10^{20}$ Neutrons $/ \mathrm{cm}^{2}$ (E > $0.1 \mathrm{MeV}$ )

at a Neutron Flux of $1.9 \times 10^{15}$ Neutrons/ $\mathrm{cm}^{2} \mathrm{sec}$

$(\mathrm{E}>0.1 \mathrm{MeV}) \quad . . . . . . . . . . . . . . . .$. 
23. Dislocation Line - Precipitate Structure in Specinen Irradiated at $460-470^{\circ} \mathrm{C}$ to $5 \times 10^{20}$ Neutrons $/ \mathrm{cm}^{2}$ (E $>0.1 \mathrm{MeV}$ ) at a Neutron Flux of Approximately $4 \times 10^{13}$ Nelitrons! $=^{2} i \sec (E>0.1 \mathrm{HeV}) \ldots . . . . . .74$

24. Examles of the Iong and Dislocation Structures Observed After Irradiation to $2 \times 10^{21}$ Neutrors $/ \mathrm{cm}^{2}$ (E > $0.1 \mathrm{MeV}$ ) at $460-470^{\circ} \mathrm{C}$. . . . . . . . . . . . . . .

25. Effect of Fast Neutron Fluence ou the Loop Structure in Type 304 Stainlegs Steel Irradiated at $460-470^{\circ} \mathrm{C} . \ldots$.

26. Geometric Represencation of the Ûrigin of Diffraction Contrast from an Edge Dislocation ............ 80

27. Geometric Representation of the Image Produced by an Interstitial Dislocation Loop . . . . . . . . .

28. Dislocation Loops with 002 and $00 \overline{2}$ Diffraction Vectors Operating ........................

29. Dislocation Network in Type 304 Stainless Steel Irradiated at $570-630^{\circ} \mathrm{C}$ to $3.7 \times 10^{22}$ Neuirousicn ${ }^{2}(E)$
C.1 MeV) ..........................

30. Voids in Type 304 Stainless steel Irradiated at $370-380^{\circ} \mathrm{C}$ to $2.0 \times 10^{21}$ Neutrons $/ \mathrm{cm}^{2}(\mathrm{E}>0.1 \mathrm{KeV}) \ldots . . . .$.

31. Effect of Fast ieutron Flinence on the Void Concentration and Size Distribution in Type 30i Stainless Steel Irradiated at $370-380^{\circ} \mathrm{C} \ldots . . . . . . . . . .$. 


\section{xi1}

FIGURE

PAGE

32. H1stogran of the Vofd Size Distribution in Type 3014

Stainless Steel Irradiated at $370-380^{\circ} \mathrm{C}$ to $5.0 \times 1 \mathrm{c}^{22}$

Neutrons $/ \mathrm{cm}^{2}(\mathrm{E}>0.1 \mathrm{MeV}) . . . . . . . . . .$.

33. Effect of Fluence on the Void Size Distribution Curva

for Type 304 Stainless Steel Irradiated at $370-380^{\circ} \mathrm{C}$. . . 90

34. Heterogeneous Void Distributions in Type 304 Stainless

Steel Irradiated at $460-470^{\circ} \mathrm{C}$ to $4 \times 10^{21}$ Neutrons $/ \mathrm{cm}^{2}$

(E > $0.1 \mathrm{MeV}) \ldots \ldots . . . . . . . . . . .$.

35. Association of Voids with Dislocation I.ines in Type 304

Stainless steel ...................

36. Voids Associated with Dislocation Lines in Specimen

Irradiated at $460-470^{\circ} \mathrm{C}$ to $0.74 \times 10^{22}$ Neutrons $/ \mathrm{cm}^{2}$

$(E>0.1 \mathrm{MeV}) \ldots . . . . . . . . . . . . .$.

37. Type 304 Stainless Steel Irradiated at $420^{\circ} \mathrm{C}$ to

$4.2 \times 10^{22}$ Neutrons $/ \mathrm{cm}^{2}(E>0.1 \mathrm{MeV})$........ 96

38. Effect of Past Neutiton Fiuence on the Shape and Concen-

tration of Volds in Type 304 Stalniess Steel Irradi-

ated at $460-470^{\circ} \mathrm{C}$.................

39. Histogram of che Void Size Distribution in Type 304

Stainless Steel Irradiated at $460-470^{\circ} \mathrm{C}$ to $2.1 \times 10^{22}$

Neutrons $/ \mathrm{cm}^{2}(E>0.1 \mathrm{MeV}) \ldots . . . . . . . .$.

40. Effect of Fast Neutron Fluence on the Vo1d S1ze Distri-

bution in Type .04 Stainless Steel Irradiated at

$460-470^{\circ} \mathrm{C}$.................... 
41. Effect of Irradiation Feaperature on the Void Concentration and Size in Type 304 Stainless Steel Irradiated to $3.7 \times 10^{22}$ Ieutross $c^{2}(E=0.1$ hevj $\ldots . . . . . .101$

42. Variation of Void Concentration with Fast Neutron Fluence

in Type 304 Stainless Steel Trradiated at 2?0-30n ant

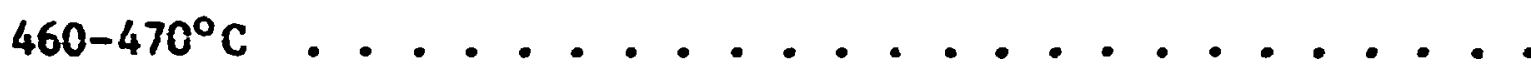

43. Variation of Void Concentration with Irradiation

Temperature .................... iún

44. Káaínim Void Diameter Versus Fast Neutron Fluence . . . 108

45. Maximum Void Diameter as Function of Irradiation Tempera-

ture for Specimens Irradiated to Fast Neutron F1uences

in Excess of $1 \times 10^{22}$ Neutrons $/ \mathrm{cm}^{2}(\mathrm{E}>0.1 \mathrm{MeV}) \ldots . . .110$

46. Microstructure of Type 304 Stainless Steel Irradiated at $390^{\circ} \mathrm{C}$ to $7.6 \times 10^{21}$ Neutrons $/ \mathrm{cm}^{2}(\mathrm{E}>\mathrm{C.1} \mathrm{MeV}) . . . . .111$

47. Microstructure of Type 304 Stainless Sters Which Contained $20 \times 10^{-6}$ Atom Fraction Helium Prior t: Irradiation at $390^{\circ} \mathrm{C}$ to $7.6 \times 10^{21}$ Neutrons $/ \mathrm{cm}^{2}(\mathrm{E}>0.1 \mathrm{YeV}) \ldots . .$.

48. Density Decrease as Function of Axtal Distance from Reactor Midplane for EBR-II Safety Rod Thimble.....

49. Density Decrease Versus Fiuence for Type 304 Stainles:

Steel Irradiated at $379-380^{\circ} \mathrm{C} \ldots . . . . . . . .18$

50. Density Decrease Versus Fluence for Type 304 Stainless

Steel Irradiated at $460-470^{\circ} \mathrm{C}$. . . . . . . . . 119

51. Density Decrease Versus Temperature . . . . . . . . 121 


$$
\text { ziv }
$$

\section{FIGURE}

PAGE

52. Energy of $a / 3\langle 111\rangle$ and $a / 2\langle 1: 0\rangle$ Dislocation Loops as a Punction of Loop Radius . . . . . . . . . . . 129

53. Typical Luading Diagram for Rows 1 Through 8 of the EBR-II . = = = =................ $16 \hat{2}$

54. Neutron Flux as a Function of Distance from the Reactor

Midplane in Row 2 of the EBR-II ............ 163 


\section{CHAPTER I}

\section{INTRODUCTION}

When metals and alloys are subjected to neutron irradiation, vacancies and interstitials are produced by displacement reactions and Impurity atoms such as hydr igen and helium are produced by transwatation reactions. Damage of both types is of interest because these defects (or clusicers of these defects) strongly affect many of tise mechanical and pingical properties. Fon a practical or applied viewpolnt it is important that the properties of a material which is to be used in a nuclear reactor are not degraded to the extent that either the safe or ecoronical operation of the reactor systen is affected.

Austeritic stainless steels have several properties which nake then attractive for use as fue: cladding and structural components in Liqufd Metal Cooled Past Breeder Reactors (IMPRR). These allojs possess adequate strength and are compatible with liquid sodiun (the reactor coolant) and with urantur-plutonium oxides (the reactor fuel) at the projected oderating temperatures. In fast reactors the neutron fluxes and neutron fluences to which cladding and other components will be subjected are much higher than those encountered in wost other reactor systems. It is thus important to know what changes ia properties will occur as a result of irradiation at conditions sindlar to those expected during service in IMFB's. 
At the time when this investigation was initiated there had been two reports that an unexpected forin of irradiation damage occurred wher austenitic stainless stzels wera irradiated at temperatures between 350 and approxinately $600^{\circ} \mathrm{C}$ to fasi neutron fluences in excess of $10^{22}$ neutrons $/ \mathrm{cm}^{2}$. Cawthorne and Fulton $(1,2)$ used transmision electron microscopy tó examine fuel cladding and tensile specimens of type 316 stainless steel which had been irradiated in the Dounreay Past Reactor to neutron fluences as high as $6 \times 10^{22}$ neutrons $/ \mathrm{cm}^{2}$ at temperacures between 270 and $6000^{\circ} \mathrm{C}$. At irradiation temperati:es above approximately $350^{\circ} \mathrm{C}$ voids which varied in size from the smallest resolvable to $1100 \mathrm{~A}$ diameter were present. Murphy and Strom (3) demonstrated that when type 304L stainless steel was irradiated in the Excerimental Breeder Reactor-II (EBR-II) at temperatures in the range 370 to $470^{\circ} \mathrm{C}$ large increases in strength and large reductions in ductility were observed in postirradiation tube burst tests at $500^{\circ} \mathrm{C}$. These results were unexpected siace previous investigations in which austenitic stainless steels were irradiated at the same temperatures but $L=$ neutron fluences an order of magnitude lower had not detected any changes in properties or microstructwe. Horeover, fundamental studies on the naturs of radiation damage indicated that in stainless steels displacement damage should be completely annealed even at lowe temperatures. The present investigation was initiated to investigate more thoroughly the nature of this unexpected damage. After the nature was established, the relationships of the irradiation-induced volds and interstitial loops with the temperature, fluence, and flux were sought and an attempt waz made to define possible void nucleation and growth machanisms. 
NEUTRON IRRADIATION DAYAGE PROCESSES

Metals or alloys subjected to neutron irradiation suffer two basic types of damage. Atons are displaced from their normal equilibrium positiouss as a resuit of being strucik by neutrons or other energetic particles. This process produces vacant lattice sites (vacancies) and leaves atoms in interstitial positions (interstitials). The second type of damage is transmutations of the constituent atoms by reactions initiated by neutron capture. The most important of these are the production of protons (hydrogen nuclei) or alpha particles (helium nuclei) by various transmutation reactions of the type $(n, p)$ and $(n, \alpha)$. When considering the changes in microstructure or mechanical or physical properties resulting from neutron irradiation, it is realized that two important quantities are the rate at which defects are produced and the distribution of defects throughout the lattice.

\section{i. DIJPLACEMRNT OF ATOKS IN SOLIDS BY NEUTRON IRRADIATION}

In order to displace an atom fror its normal lattice site into an interstitial fosition a minimum amount of energy, called the cisplacement energy, $E_{d}$, must be supplied to that a: m. Sietz (4) estimated the value of $E_{d}$ to be approximately $25 \mathrm{eV}$. This estimate was based on the arginent that the binding energy of an interior atom should be approximately twice the sublimination energy, 1.e., to a first approximation twice as many bonds wou!ld have to be broken in removing an interior atom 
from tts lattice site as when reming a surface atom. In addition, this displacement of an atom from its normal lattice position does not occur in a reversible manner. Sietz estimated that a reasonable value of $E_{d}$ was four to five times the sublimation energy or approximately 25 eV tor a eypical solid. This estimate is in good agreement with experimentally detarnined values listed by Relly (5).

Düiñz neutron frradiation, atom displacements can occur by several differeat mechanisms. A neutron may elastically collide with an atco and transfiar sufficient kinetic energy to the atom to displace it from its lattice site. Such an atom may receive sufficient kinetic energy to produce etill furtier displacements. A second mechanism is a resuzt of suclear reactions of the type $\left.{ }^{10_{B(n, \alpha)}}\right)^{7}$ or $\left.{ }^{58_{F e}(n, \gamma)}\right)^{59} \mathrm{Fe}$. The recorl bucleus may leave its lattice site with sufficient energy to cause other displacements. Another possibility is the interaction of the renction product (such as the a particle) with other lattice atoms. Only the elastic scattering makes a significant contribution to the etunde difpilasements produced by the collision of fast neutrons with latcice atous. Reactions of the type $(n, y),(n, \alpha),(n, p)$ or $(n, 2 n)$ prouce vory imall fraction of the total displacements and can thus be ignorad. In an elastic collision the maximum amount of energy, En' mich be transferred from a neutron of energy $E_{n}$ to a nucleus of atoute ight is given by

$$
E_{m}=\frac{4 A}{(A+1)^{2}} E_{n}
$$


For isotropic scattering, the scruck nurleus has equal probability of recelving any energy between $J$ and $E_{m}$. The average energy transferred by such a collision is thus $E_{10} / 2$.

If an atom which is struck by a neutron receives energy in excess of $E_{d}$ it is displaced from its lattice site. Such an atom is called a Primary Rnock-on Atom (PRA). As a PRA travels througn the lattice it strikes other atoms, transferring energy to them and displacing them from their lattfce sites. The quantity $V(E)$ is defined as the number of additional displacements made by a PRA as it slows down from energy $E$ to the position in the lattice where it is in thermal equilibrium with its surroundings. To obtain $V(E)$ the model and calculations of Rinchin and Pease (6) are used. These authors give:

$$
\begin{array}{lll}
0 & \text { for } & 0 \leq E \leq E_{d} \\
1 & \text { for } & E_{d} \leq E \leq 2 E_{d} \\
E / 2 E_{d} & \text { for } & 2 E_{d} \leq E \leq L_{c} \\
L_{c} / 2 E_{d} & \text { for } & E \leq L_{c}
\end{array}
$$

In this treatment, $L_{c}$ is called the ionization cutoff energy and is defined as the energy of an atom wroving, shrough a solid above which energy is lost o.aly by electronic excitation (1.e., fonization) and belcw which energy .losses occur only by elastic collisions. Dienes and Vineyard (7) assume that $I_{c}$ is given by

$$
\mathrm{L}_{c}=\mathrm{A} \times 10^{3} \mathrm{eV}
$$


Consider neutrons of energy $E_{n}$ produsing PKA's having average eaergy

$$
E_{\text {averags }}=\frac{E}{2}=\frac{2 A}{(A+1)^{2}} E_{n}=\frac{\overline{\alpha E}_{n}}{2}
$$

where $\bar{\alpha}=4 A(A+1)^{2}$. The average number of displacements produced by these primary knock-ons is $\bar{v}\left(E_{n}\right)$, and is given by

$$
\begin{aligned}
& 0 \quad \text { for } \bar{E}_{\mathrm{n}}<\mathrm{E}_{\mathrm{d}} / \bar{\alpha} \\
& 1 \text { for } \mathrm{E}_{\mathrm{d}} / \bar{\alpha} \leq \mathrm{E}_{\mathrm{n}} \leq 2 \mathrm{E}_{\mathrm{d}} \sqrt{\alpha} \\
& \bar{v}\left(E_{\mathfrak{a}}\right)= \\
& \bar{\alpha}_{\mathrm{n}^{\prime}} \mathrm{E}_{\mathrm{d}} \quad \text { for } \quad \frac{2 \mathrm{E}_{\mathrm{d}}}{\bar{\alpha}} \leq \mathrm{E}_{\mathrm{n}} \leq \mathrm{L}_{\mathrm{c}} / \bar{\alpha} \\
& \frac{\mathrm{L}_{c}}{4 \mathrm{E}_{\mathrm{d}}}\left[2-\frac{\mathrm{L}_{c}}{\bar{\alpha}_{\mathrm{n}}}\right] \quad \text { for } \quad \frac{\mathrm{L}_{c}}{\bar{\alpha}} \leq \mathrm{E}_{\mathrm{d}}
\end{aligned}
$$

The expression for $\bar{v}\left(E_{n}\right)$ as a function of $E_{n}$ for iron $(A=56)$ is plotted in Figure 1. The number of displacements per PKA incrases linearly with neutron energy for energies between approximately $10^{3}$ and $10^{6} \mathrm{ev}$ and then saturaces rapidiy for neutron energies above approximately $2 \times 10^{6} \mathrm{eV}$ (2 MeV). The number of displacements per unit volume per unit time is given by

$$
\frac{d n}{d t}=N_{0} \int_{E_{d} / \bar{\alpha}}^{\infty} \phi\left(E_{n}\right) \sigma\left(E_{n}\right) \bar{v}\left(E_{d}\right) d E_{n},
$$




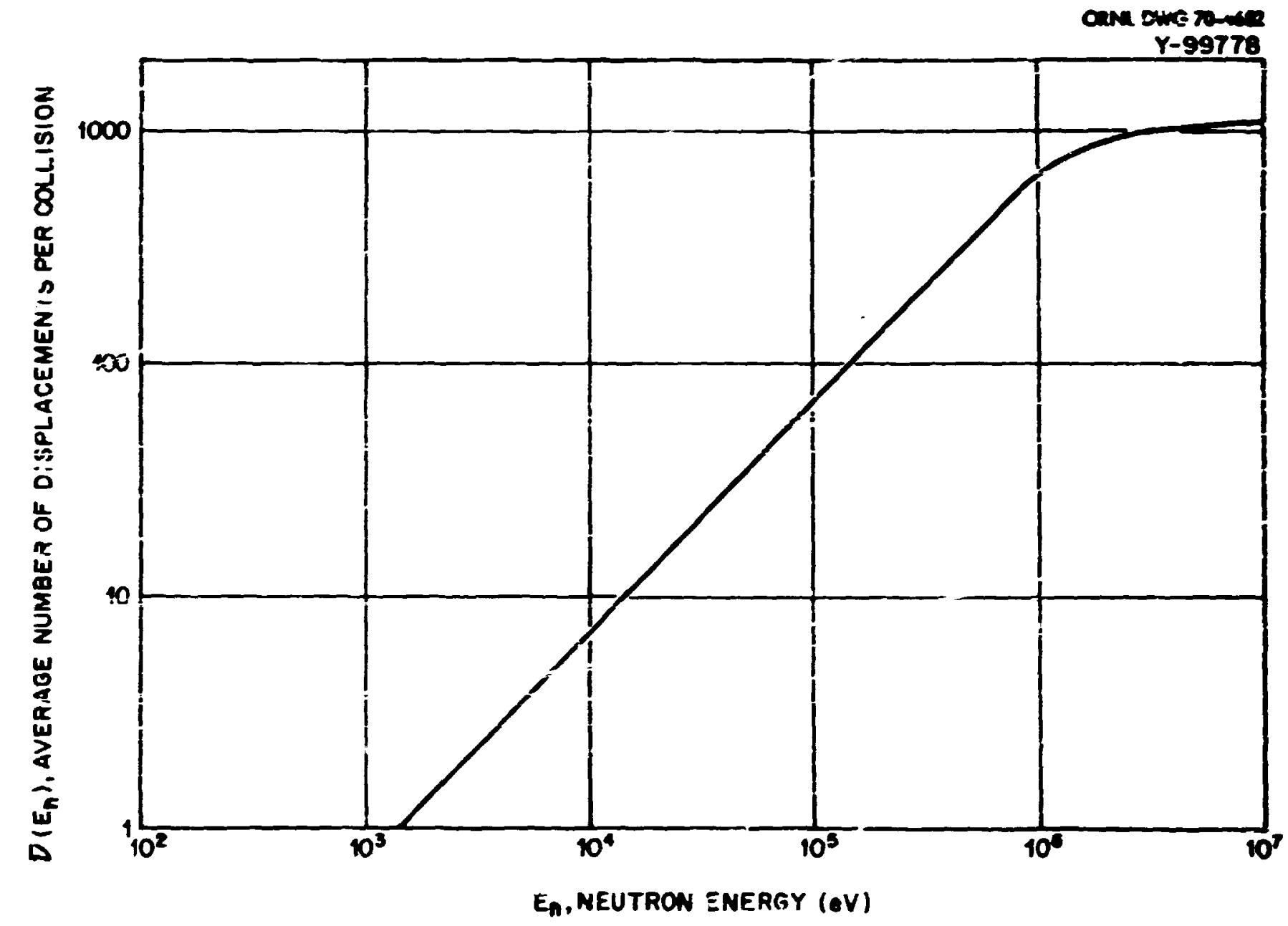

Figure 1. Average number of stom displacements as a function of neutron esergy in iron (atomic weigitt 56). 
where

$$
\begin{aligned}
N_{0} & =\text { number of atoms per unit volume, } \\
\sigma\left(E_{n}\right) & =\text { atomic cross section for elastic scattering, and } \\
\phi\left(E_{n}\right) d E_{n} & =\text { flux of neutrons having energies between } E_{n} \text { and } \\
& E_{n}+d E_{n} .
\end{aligned}
$$

The spgetial discributiou of the dispiacement damage produced by fast neutrons is very important. First, the PRA's are distributed uniformig throughout the bult of the material since the mean free path between reutron-atom collisions is of the order of centimeters. The defects produced by the individuel PKA's, however, are not produced homogeneously on an atomic scale. Seitz and Koehler (8) calculate that an atom moving with exergy less thin $\mathrm{L}_{a}$, where $\mathrm{L}_{a}$ is given by

$$
L_{a} \approx 42^{7 / 3} R_{h}
$$

will undergo hard-sphere collisions. In equation (7) 2 is the atomic number and $g_{h}$ is the Rydberg energy for hydrogen. In the case of iron $(Z=26)$, PRA:s having less inan about $10^{5}$ eV energy undergo hard-sphere coilisions. Cals:iations usliag equation (1) shos that most of the PRA's have lass than this amount of energy. The effectivt radfin in in $^{\text {; }}$ of an atom for hard-sphere collisions is a functisn of the PKA energy and is given by

$$
g_{e}=\frac{a_{n}}{(2)^{1 / 3}} \quad 1 n \frac{q^{2} e^{2}}{R_{h}}
$$


where

$$
\begin{aligned}
& a_{n}=\text { Bohr radius of iydrogen aton, } \\
& e=\text { electron charge, and } \\
& E=\text { energy of moving atom. }
\end{aligned}
$$

The mean free path between hard sphize collisions $\mathrm{L}_{\mathrm{HS}}$ is given by

$$
L_{H S}=\frac{i}{\pi R_{e}^{2} N_{0}} \text {. }
$$

Thus, as the energy of a moving aton decreases, $R_{e}$ increases and $L_{\text {th }}$ decreases. As the kinetic energy of a moving atom is dissipated it begins to coilide with essentially every atom in its path. Kost of the atom displacements occur in a very small volune called a displacement spike. Several investigators have suggested what the final configuration of the atoms inside a displacement spike night be. Using the terminology of Beeler $(9,10)$, this is ine "primary damage state" or the defect distribution produced directly by the PRA at $0^{\circ} \mathrm{K}$ temperature where no thermally induced rearrangement can occur. Brinkman (11) has suggested that because of the large amount of energy dissipated in a small volume the atoms will recrystalize in correct registry with the surroundings but will leave small clusters of vacancies and interstitials. Seeger (12) argues that after immediate rearrangement the spike will be a region of high vacancy concentration. Kincinin and Pease (6) suggest that the spike will consist of volume having a high vacancy concentration surrounded by a shell which contains a high concentration of interstitials. 
Cosputer calculations performed by Beeler $(9,10)$ indicate that the primary damage state is simflar to that proposed by Kinchin and Pease.

\section{TRANSMUTATION REACTIONS}

During neutron Irradiation $(n, p),(n, \gamma)$, and $(n, \alpha)$ reactions are initiated by the nuclei of atoms capturing neutrons. Bach reaction of this type produces either a new isotope, as is the case with $(n, Y)$ reactions, or a chemically different spacies, as is the case with $(n, p)$ and $(n, \alpha)$ reactions.

With the exception of hydrogen and helfim, the chemicaliy different species produced ty transmutation reactions usually do not nave metallurgical significance since their concentration buflds up slowly and usually does not exceed either the concentration of impurities inftially present in the material or the solubility limits for the product species. Exceptions to this statement include the production of silicon in aluminum (13) and rhenium in tungstun (14).

Helium produced by $(n, \alpha)$ reactions poses a different situation. Because of its chemically inert electronic structure, helium is highly insoluble in the metal lattice. Cottreil (15) gives the atomf concentration $C$ of a monoatomic gas dissolved with a free energy $F$ in equilibrium with a gas phase at a pressure $p$ and temperature $T$ as:

$$
C=\frac{p}{N_{0} k T} e^{-F / k T}
$$


Since there would be a large amount of strain energy associated with a helius atom in an interstitial position, cottrell proposed that each aton would enter substitutional solution by capturing a vacancy. Thus the energy of solution would be primarily the energy of formation of a vacancy; about $1 \mathrm{eV}$ for a face-centered cubic metal. Taking $p=1$ ata, $T=1000^{\circ} \mathrm{K}$, and $P=1 \mathrm{eV}$ then the solubility is on the order of $10^{-9}$.

Russell and Hastings (16) have followed the precipitation of helium from interstitial solution by neasuring the changes in lattce parameter on post irradiation annealing of copper-boron alloy. Initially, the hellum atoms forwed by the ${ }^{10} B(n, \alpha)^{7} L 1$ reaction were in interstitial pisitions. The results indicated that, during amealing, each helium atom captured two vacancies and entered substitutional solution. Continuation of the annealing to hipher temperatures caused the helium to precipitate in gas bubbles. Il ese processes caused the lattice to contract initially, as the helium atoms captured vacarcies and moved fnto solid solution, and then expand $a_{6}$ ain and approach the unirradiated value as the helium precipitated in bubbles.

The formation of helium bubbles in irradiated materials has been reported by several investigators $(17,18,19,20)$. The effects of helium on the mechanicas properties have been extensively investigated and reviewed $(17,13,19,20,21,22)$.

T. $C_{i}$ irradiation in a fast reactor neutron spectrum most of the helium is produced by $(n, \alpha)$ reiactions with high energy neutrons. Alter and Weber (23) and DePino (:4) have estimated the amounts of helium produced in austenitic stainless steels irradiated in a fission neutron 
spectrum and a typical fast reactor neutron speccrum, respectively. Calculations of this type are not accurate since cross sections for $(n, \alpha)$ reactions are in general not well known. The results are interesting, hovever, since they shon the reiative fmortance of the various elements present in a stainless steel to the total helium production. DePino exanined all of the constitutents in a type 394 stainless steel and concluded that, in a fast reactor neutron sfectrun, over 907 of the total hellu was produced from iror, chroniun, nickel, nitrogen and boron. These calculations are sumarized is Figure 2. Irradiation to a neutron fluence of $<1.7 \times 10^{19}$ neutrons $/ \mathrm{cm}^{2}$ (thermai) and $6.6 \times 10^{23}$ neutrons $/ \mathrm{cm}^{2}$ (E $>0.18 \mathrm{HeV}$ ) would produce approxdmately $150 \mathrm{ppa}$ heliu (2.3 ppa heliu per $1 \times 10^{22}$ neutrons/ $\mathrm{cm}^{2}$ ). Siailar calculations performed by Alter and Weber (23) give a helfur production rate of approximately 5.5 atonic ppa heliun per $1 \times 10^{22}$ neutrons/cm ${ }^{2}$ for 304 statnless steel irradiated in a fission neutron spectrum. To a first approxination, the helium production rate is constant with time over the duration of the irradiation.

Hydrogen is produced by $(n, p)$ reactions. Calculations by Alter and Weber, for a fission neutron energy spectrum, indicate that in type 304 stafaless steel, the hydrogen production rate is 109 atomic ppw iygirogen per $1 \times 10^{22}$ neutrons $/ \mathrm{cm}^{2}$. Of the total hydrogen produced, approxtmately $30 \%$ somes from $(n, p)$ reactions with the iron isotnpes and approximately 662 from $(n, p)$ reactions with the ofckel 1sotopes. In alistenitic statnless steels and nickel base alloys irradiated at elevated temperatures, it has been suggested that hytrogen will diffuse from the 


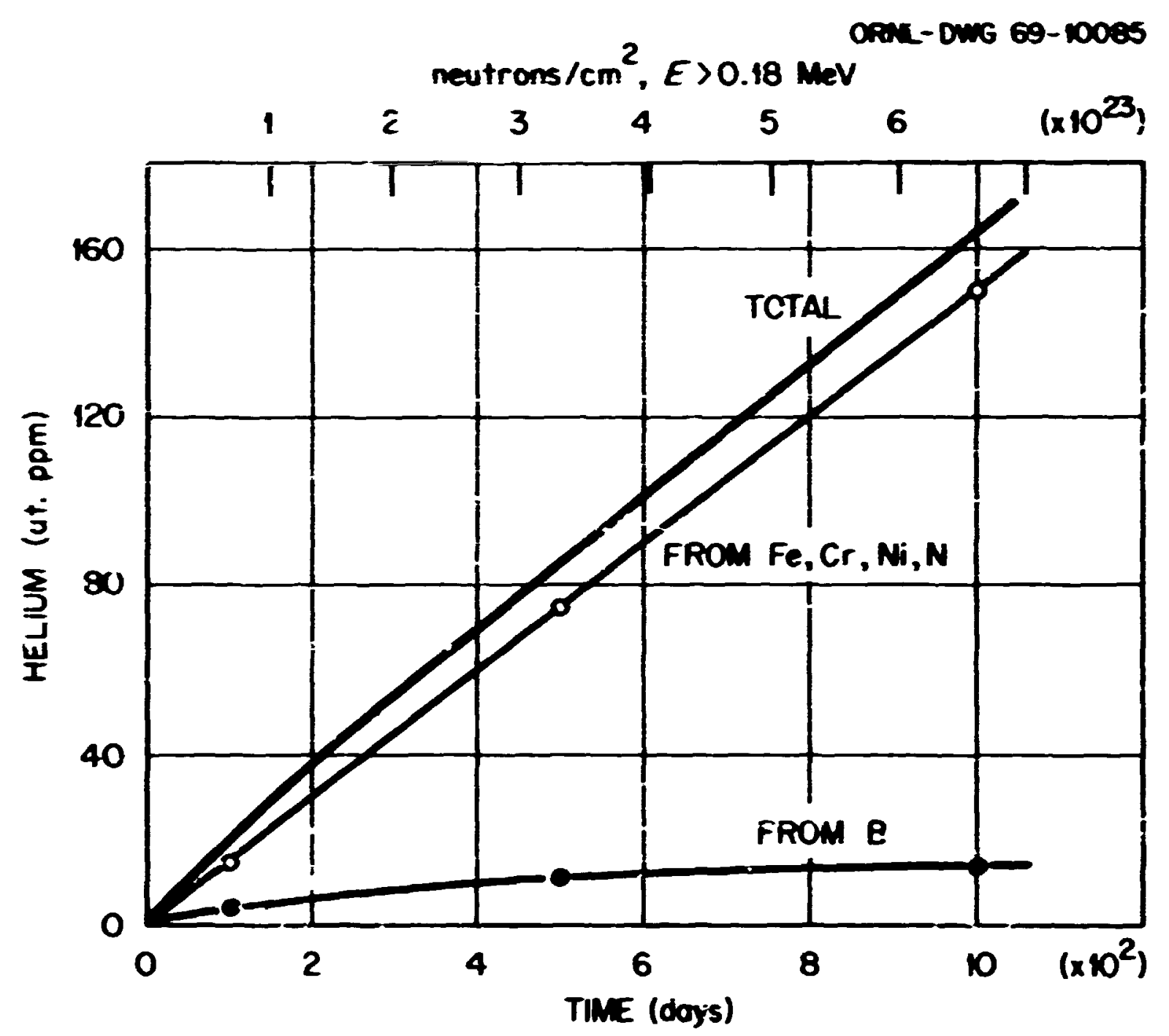

Figire 2. Calculated heliu concentration in type 304 stainless steel as a fucition of the fast neutron fluence.

A. DePfno, Jr., "Hellum Production by $(n, \alpha)$ Reactions in Stainless Stee1," Nuclear Applications 3, 620 (1967). 
naterial rapidly enough to prevent the concentration froverceeding the solubility linit (17). 
FORMATION OF DEFFCT CIUS'IERS

As discussed previously, the primary damage state or the defect distribution produced directly by the PRA probably consists of a volume which has a high concentration of vacancies surrounded by a shell which has a high concentration og interstitials. Since reactor irradiations are nearly always carried out at temperatures at which one or more of the irradiation-profuced defects are mobile, this primary damage scate is highly unstable and dynanic recovery wi.l occur. Many of the original irradiation-produced vacancies and interstitials will be annihilated by recombination, trapped at impurities or absorbed by dislocations and grain boundaries. Any irradiation produced defect which survives will be thermodynamically unstable (i.e., there will be a supersaturation of vacancies and interstitials) and may cluster with defects of like ikinit in order to lower the free energy of the system. The formation of defect clusters and the fina?. damage state will thus deper'. upon material parimeters such as surface and stacking fault energies, energy of formation of vacancies and interstitials, migration energy of vacancies and interstitials, the binding energy of vacancies and interstitials to defect clusstêrs, and irradiation paraméterss such̀ as the irradiation temperature, fast neutron flux, fast neutron fli:ence, etc.

In the folloring section, the calculation of the stability of various defect configurations will be considered and the experimental 


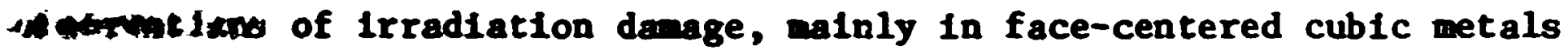
ad allign. wll be reviered.

\section{STABILITT OF VARIOOS DEFECT CONFIGURATIONS}

In a pure metal quenched from an elevated temperature, the concentration of vacancies in equilibriun at that temperature may be maintained at a lower temerature to form a supersaturated condition. The vacancies can cluster on wnealiag to form several distinct types of defects. Sinilarly, during irxadiation a vacancy supersaturation is maintained and one might expect various types of vacaccy clusters to forn. Because of their large enerzy of formation and high mobility, it is not possible to quench in a significant supersaturation of interstitials. During irradiation, however, interstitials are produced in equal rumbers to vacancies and the formation of interstitial clusters must also be considered. Boith vacancies and Interstitials precipitate to form defects such as "faulted" dislocation loops (loops which surround a ste.cking fault), "perfect" dislocation loops (loops which surround unfaulted material) and possibly stacking fault tetrahedra. In addition, vacancies may precipitate to form three-dimensional voids.

In principle, the defect having the $m$ inim free enerzy should form. For dislocation loops, the total energy is the sum of the energy associated with the dislocation and the energy associated with any stacking fault. The energies associated with faulted and perfect loops of radius $R_{\ell}$ are given by equations (11) and (12) respectively: 


$$
\begin{aligned}
& E_{f}=\frac{2}{3} \frac{1}{(1-v)} \pi b^{2} R_{\ell}\left(\ln \frac{4 R_{l}}{r_{0}}-2\right)+\pi R_{\ell}^{2} Y, \\
& \left.E_{P}=\frac{2}{3} \frac{1}{(1-v)}+\frac{1}{3}\left(\frac{2-v}{2(1-v)}\right)\right] G b^{2} R_{\ell}\left[\frac{R_{l}}{r_{0}}-2\right],
\end{aligned}
$$

where

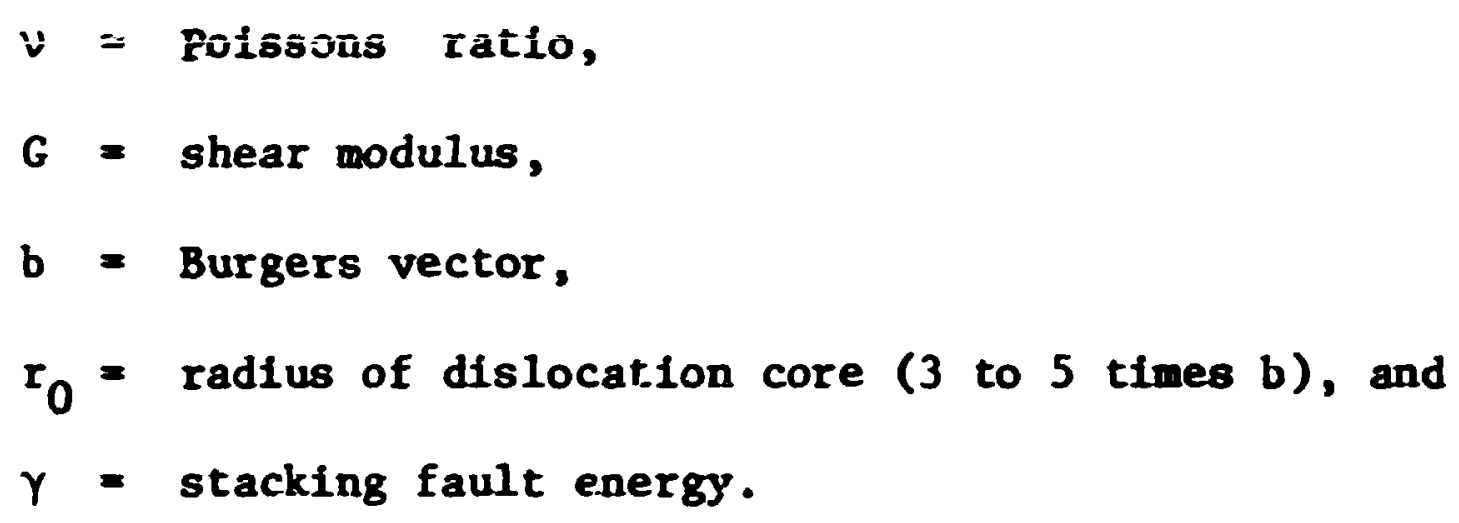

For vacancies precipitating as a spherical void of radius $R_{v}$, the energy assoclated with the void is given by:

$$
E_{s}=4 \pi R_{v}^{2} \sigma
$$

where $\sigma$ is the surface energy.

Sigler and Kuhlnan-Wilsdorf (25) have calculated the relative stabilities of several different types of vacancy clusters in aluminum, nickel, platinum, copper, gold and silver. Their results indicated that when the ratio of surface energy to stacking fault energy was less than 10, e.g., aluminum and nickel, the void was the most stable vacancy cluster whereas when this retio was greater than 10, e.8., platinum, gold, copper and silver, a stacking fault tetrahedron was the most stable cluster. The results for nickel agree with similar calculations performed by Johnson (26). 
For the precipitation of interstitials, the stacking fault energy is again an importent parameter. If the stacking fault energy exceeds a value given by

$$
Y \geq \frac{G b^{2}}{3 \pi R_{l}}\left[\frac{2-v}{2(1-v)}\right] \ln \left[\frac{4 R_{l}}{r_{0}}-2\right]
$$

tibe loop will be a perfect loop; whereas if $\gamma$ is less than this value, itie loop will have an associated stacking fault.

Calculations $j \dot{f}$ this type have only inted applicability to very small defect clusters. For swall dislocation loops the core energy of the dislocation dominates the energy expression and this term is not well known. For three dimensional defect clusters surface energy terms and defect shapes are not well known. It 18 also poseifife that as a defect grows in size, some other configuration pay have lower energy, but the defect may not be able to convert to this configuraticn because of an energì barrier or kinetic factors.

\section{IRRADIATION DAMAGE IN PURE FACE-CERTERED CUBIC METALS}

In pure face-centered cubic (fcc) metals irradiated at low temperatures below approximateiy $0.3 \mathrm{~T}_{\mathrm{m}}$ (whera $\mathrm{T}_{\mathrm{m}}$ is the melting temperatire in ${ }^{\circ} \mathrm{K}$ ) two distinct types of defect clusters have been reported. Silcox and Hirsch (27) first reported prismatic dislocation loops in copper which had teen neutron-1rradiated at temperatires in the range 35 to $100^{\circ} \mathrm{C}$. Burnes and Mazey (28) sbseryed dislocation loops of approximately 200 A diameter as well as a wich higher iensity of opaller 
defects, approximately 20 A diameter, in both copper and aluninum which had been boubarded with a particles. The nature of these defects was inferred from pobt-tomardwent mealing atudias. The larger loops vere thought to be interstitial in nature and we smaller loops were thought to be vacancy clusters. Sintlar observations of defects in neutron Irradizied copper have been made by Makin et al. $(29,30)$; and Koppenaal et al. (3i), and Herkle (32).

The nature of the small dislocation loops in neutron irradiated materials has been the subject of considerabie controversy. Quartitative electron microscopy studies which utilize the black-white contrast fron the strain field of the loops have at various times been interpreted to show the loops in copper to be entirely interstitial in nature $(33,34)$, entirely vacancy in character (35), and aixtures of both interstitial and vacancy loops (36). It thus appears quite possible that both cluster types may be formed.

Reports of damage in irrediated pure nickel are also conflicting. Greenfleld and H1lsdorf (37) did not observe damage in nickel which was zeutron irradiated at $70^{\circ} \mathrm{C}$ to a fast neutron fluence of $1 \times 10^{18}$ neutron/ $\mathrm{cm}^{2}$. At the higher irradiation temperature of $200^{\circ} \mathrm{C}$, damage was detected as dark spots in electror mierográphs (approximately $2.3 \times 1 \mathrm{C}^{15} \mathrm{spots} / \mathrm{cm}^{3}$. In contrast, Bell (38) has observed defect clusters in nickel irradiated at $80^{\circ} \mathrm{C}$ to $5 \times 10^{18}$ reutrons $/ \mathrm{Ca}^{2}(\mathrm{~B}>1 \mathrm{KeV}$ ) and Brimhall et al. (39) observed defect clusters in nickel irradiated at $40^{\circ} \mathrm{C}$ to $2.5 \times 10^{18}$ neutrons/ $\mathrm{cm}^{2}$ ( $\mathrm{E}>1 \mathrm{MeV}$ ). Brimhall et al. found the wajority of the defects to be vacaucy clusters. Hore recently, Bourret and Dautreppe (40) 
Irradiated nickel at $77^{\circ} \mathrm{K}$ and then examined it at zoom temperature. After Irradiation, the danage structure consisted of interstitial Frank dislocation loops and vacancy clusters thought to be small tetrahedral volds.

It was not unt1l a report by Carthorne and Pulton $(1,2)$ (to be discussed lazer) ố a compiex denage structure consising of voids and dislocation loops in an austenftic stainiess steel irradiated at temperatures between 0.38 and $0.50 \mathrm{~T}_{\text {mat }}$ threstigators began to examine pure netals Irradiated at temeratures above $0.3 \mathrm{Im}$. Since then there have heen geveral reporte of damage in nure face-centered cubic metgle irridiated in the temperature range of 0.3 to $0.5 T_{m}$.

In copper irradiated at about $0.5 \mathrm{Tm}$ to $1 \times 10^{18}$ neutrons $/ \mathrm{cm}^{2}$ (fast), Hulett et al. (41) found a nonhomogeneous distribution of vacancy and interstitial loops. Brimaii and Mastel (42) observed volds in copper irradiated to $1.2 \times 10^{20}$ neutrons $/ \mathrm{cm}^{2}(\mathrm{E}>1 \mathrm{MeV})$ at $0.39 \mathrm{~T}_{\mathrm{m}}$. Brimhall and Mastel (42) and Mastel and Brimhall (43) have reported the presence of voids in pure nickel irradiated at temperatures in the range 0.31 to $0.42 \mathrm{~T}$ to fast neutron fluences as $10 \mathrm{w}$ as $4 \times 10^{19}$ neutrone/ $\mathrm{cm}^{2}$ ( $E>1 \mathrm{MeV})$. The volds appeared to be cctahedra with surfaces bounded by $\{111\}$ planes. Annealing experiluents were used to demoustrate that the volds were not filled with gas.

Holmes (44) has measured the density decrease due to void formation as a function of fast neutron fluence in high purity (99.987) nickel (nickel 270), a commercial purity (99.6\%) nickel (rickel 200) and a nickel base alloy (Inconel 600) which contalned $737 \mathrm{N1}, 177 \mathrm{Cr}$, and 87 
Fe. The irradiation temperature vas $437 \pm 28^{\circ} \mathrm{C}$. These resul:zs are shown in Figure 3. Nickel 270 exhibited the bighest rate of volume change and the rate in nickel 200 was interwediate. Inconel 600 showed a strall but consistent decrease in volime. This latter observation vas thought to be jue to surface reactions with the reactcr coolant. Nickel exhibits a significant volume change at iow fluences and follows a linear relationship between fluence and swelling. In stainless steel volds are not observed until much higher ?liences and there is a porer law retween swejling and neutron fluence. Holmes suggested that this difference might be due to statking fault energy. The high stacking fault energy of nickel makes a joid an energetically wore favorable configuration than a vacancy loop while the low stacking fault energy of stainless steel should ake vold formation less favorable. Stiegler and coworkers (13) compared the danage structures produced in high purity (99.9997) and cosnercial purfty (997) aluninua as a result of irradiation at $50^{\circ} \mathrm{C}$ to a fluerice of $3.5=10^{20}$ nevereso' $\mathrm{cm}^{2}$ ( $\left.\mathrm{B}>0.82 \mathrm{MeV}\right)$. Octahedral voids and dislocation loops were observed in the high purty alminum. Contrast analysis of the 12zger icops proved them to be the vacancy type. The distribution of volds and 100p8 was nonualform; areas which contalned large voids had small 10ops, and vice versa. The heterogeneous distribution of volds was thought to be due to dissolved impurities, possibly gases which night stabilize vold nuclei. In commercial firity aluminum irradiated at $50^{\circ} \mathrm{C}$ to $3.5 \times 10^{20}$ neutrons $/ \mathrm{cm}^{2}(\mathrm{~B}>0.82 \mathrm{MeV})$, the only visible damage was dislocation locis of both the vacancy and interstitial type. Brimhall and Mastel 


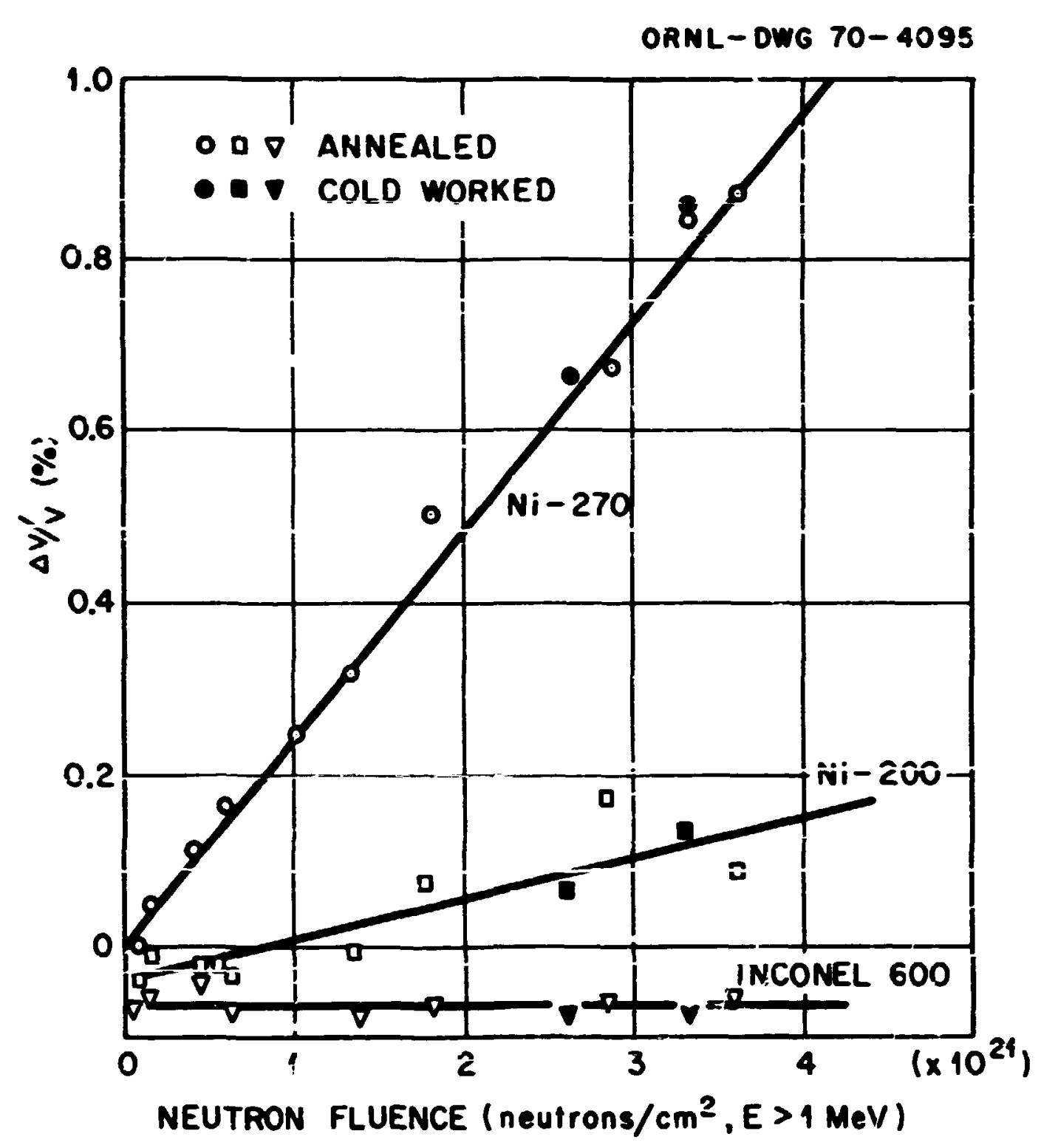

Figure 3. Density decrease in high purity nicliel (Ni 270), comercially pure nickel (N1 200), and a nickel base alloy (Inconel 600) as a result of neutron irradiation.

J. J. Holmes, "Irradiation Induced Swelling in Nickel Alloys," Trans. Am. Nucl. Soc. 12, 117 (1969). 
(42) have also observed voids in aluminum also frradiated at $50^{\circ} \mathrm{C}$ but to a fluence of $3 . ? \times 10^{19}$ neutrons $/ \mathrm{cm}^{2}$ ( $\left.\mathrm{B}>1 \mathrm{MeJ}\right)$.

Table I sumarizes the data on the observation of volds in pure fcc metals Irradiated at temperatures between 0.3 and $0.5 \mathrm{~T}_{\mathrm{m}}$. Voids have been observed in metals having both low and high stacking fault energies, copper and aluminu respectively. With increasing Irradiation temperature the mean vold dianeter increases and the void concentration decreases. The results of Stiegler et al. (13), Stfegler and Bloom (46) and Hulett et al. (41) suggest that early in the irradiation the danage may be heterogeneously distributed.

\section{IRRAEIATION DAMAGE IN AUSTENITIC STATMLSS STEBLS}

As is the case with pure fcc metals. the type of dimgge groduced in austenitic stainless steels by neutron irradiation depends on the Irradiation temperature and the fast neutron fluence. Hilsdorf and Ruhlmann-Wilsdorf (48) did not detect any damage in a type 304 stainless steel Irradiated in the annealed condition to $1 \times 10^{19}$ neutrons/cm (fast) at ambient reactor temperature (approximately $50^{\circ} \mathrm{C}$ ). Aratjo et al. (49) observed damege in spectūens irradiated at 43 and $343^{\circ} \mathrm{C}$ to fast neutron fluences of $1 \times 10^{20}$ and $1 \times 10^{21}$ neutrons/cm ${ }^{2}(\mathrm{E}>1 \mathrm{MeV}$ ) respectively. Bloum et al. (50) studied the Iriadiation produced defects for Irradiation temperatures between 90 and $454^{\circ} \mathrm{C}$. The speciriens, which were annealed type 304 stainless steel, were irradiated to $9 \times 10^{20}$ neutrons $/ \mathrm{cm}^{2}$ (thermal) and $7 \times 10^{20}$ neutrons $/ \mathrm{cm}^{2}$ (E > $1 \mathrm{MeV}$ ). The microstructure of a specimen irradiated at $93^{\circ} \mathrm{C}$ is shown in Figure 4. A high 


\section{'CABLE I}

CHARACTERISTICS OF VOIDS IN IRRADIATEI) PURE VETALS

\begin{tabular}{|c|c|c|c|c|c|}
\hline $\begin{array}{c}\text { Metal } \\
\text { and } \\
\text { Reference }\end{array}$ & $\begin{array}{c}\text { I I cadiation } \\
\text { Temperature } \\
{ }^{\circ} \mathrm{C} \\
\end{array}$ & $\begin{array}{l}\text { Irradiatilon } \\
\text { Temperatidra } \\
\text { Fraction } \\
\text { of } \mathrm{T}_{\mathrm{m}} \\
\end{array}$ & $\begin{array}{c}\text { Neutron } \\
\text { Pluence } \\
\text { Neutrona/ } \mathrm{sm}^{2} \\
\mathrm{E}>\mathrm{MaV} \\
\end{array}$ & $\begin{array}{c}\text { Minan } \\
\text { Vistd } \\
\text { Dianetex } \\
\text { M }\end{array}$ & $\begin{array}{c}\text { Vold } \\
\begin{array}{c}\text { Concentration } \\
\text { Volda/ } / \mathrm{cm}^{3}\end{array} \\
\end{array}$ \\
\hline \multicolumn{6}{|l|}{ N1ckel } \\
\hline $\begin{array}{l}42 \\
43 \\
45\end{array}$ & $\begin{array}{l}260 \\
380 \\
500 \\
575\end{array}$ & $\begin{array}{l}0.31 \\
0.38 \\
0.45 \\
0.49\end{array}$ & $\begin{array}{l}1.2 \times 10^{3.0} \\
5.7 \times 10^{.99} \\
5.7 \times 10^{3.9} \\
6.2 \times 10^{3.9}\end{array}$ & $\begin{array}{r}150 \\
83 \\
1.55 \\
2.45\end{array}$ & $\begin{array}{r}2 \times 10^{16} \\
4 \times 10^{15} \\
8 \times 10^{14} \\
2.5 \times 10^{14}\end{array}$ \\
\hline 46 & $370-545$ & $0.38-0.48$ & $1.4 \times 10^{: 10}$ & $-\cdot--$ & -- \\
\hline \multicolumn{6}{|l|}{ Copper } \\
\hline 42 & 260 & 0.39 & $1.2 \times 10^{20}$ & 2.30 & $3 \times 10^{.14}$ \\
\hline \multicolumn{6}{|c|}{$\begin{array}{l}\text { Alunalnum } \\
\text { (H1gh Pur1ty; }\end{array}$} \\
\hline $\begin{array}{l}42 \\
13 \\
47\end{array}$ & $\begin{array}{l}50 \\
50 \\
55\end{array}$ & $\begin{array}{l}0.35 \\
0.35 \\
0.35\end{array}$ & $\begin{array}{c}3.2 \times 10^{1.9} \\
3.5 \times 10^{20} \\
1 \times 10^{19^{2}}-1 \times 10^{22}\end{array}$ & $\begin{array}{l}2 \% \\
\text { Not Reportisd } \\
\text { n.o. }\end{array}$ & $\begin{array}{l}\text { Not Reported } \\
1.3 \times 10^{14} \\
-\end{array}$ \\
\hline \multicolumn{6}{|c|}{$\begin{array}{l}\text { Aluminum } \\
\text { (Commercial Purity) }\end{array}$} \\
\hline 13 & 50 & 0.35 & $1.5 \times 10^{2.2}$ & lot Roportud & Not Reported \\
\hline
\end{tabular}




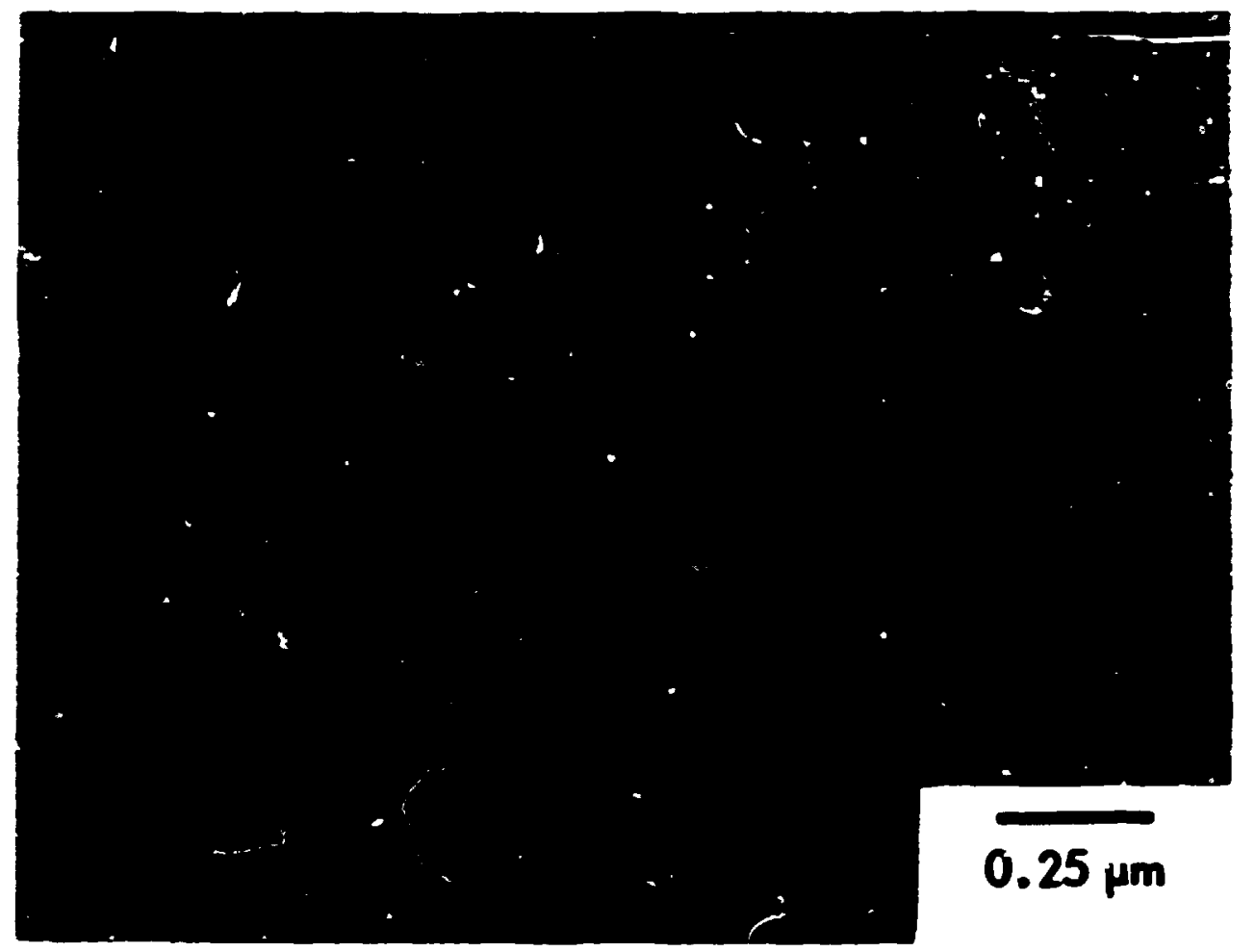

Figure 4. Type 304 stainless steel irradiated at $93^{\circ} \mathrm{C}$.

E. E. Bloom, W. R. Martin, J. 0. Stiegler, J. R. Weir, "The Effect of Irradiation Temperature on the Strength and Microstructure of Stainless Steei," J. Nucl. Mat1. 22, 68 (1967). 
concentration of defect clusters which appeared as black dots in diffraction contrast was present. With increasing irradiation temperature, up to apfroxinately $300^{\circ} \mathrm{C}$, the concentration of such defect clusters decreased and their size increased slightly. Between 300 and $371^{\circ} \mathrm{C}$ (Figure 5) there was a warked change in the damage structure. The concentration of dot-1ike defect ciusters decreased markedly ard a rod or piace-iike precipitate appeared. The smail dot defects were completely abient in specimens irradiated at $398^{\circ} \mathrm{C}$ and well-defined precipitate particles whose contrast sugges sed the presence of a strain field were present. After irradiation at $454^{\circ} \mathrm{C}$ (Figure 6) the precipltates were coarser, and when the specimens were examined in absorption contrast, small dite dots (indicating thin areas in the foil) were observed. The nature of the dots was not knorn. It was suggested that they were efther heliun bubbles or areas where small precipitates had falien from the foil.

The character of the damage structure at irradiation temperatures below approximately $350^{\circ} \mathrm{C}$ does not appear to change with increasing fast neutron fluence. Cawthorne and Fulton $(1,2)$ have examined specimens irradiated to approximately $3 \times 10^{22}$ neutrons/ $\mathrm{cm}^{2}$ and at temperatures less than $350^{\circ} \mathrm{C}$. Only a high density of dot-like defect clusters was observed.

At Irradiation temperatures above $350-370^{\circ} \mathrm{C}$ and at high fast netitron fluences the damage has an entirely different character. Cawthorne and Fuiton were the first to report a damage structure consisting of voids and dislccation loops in an austenttic stafnless steel 


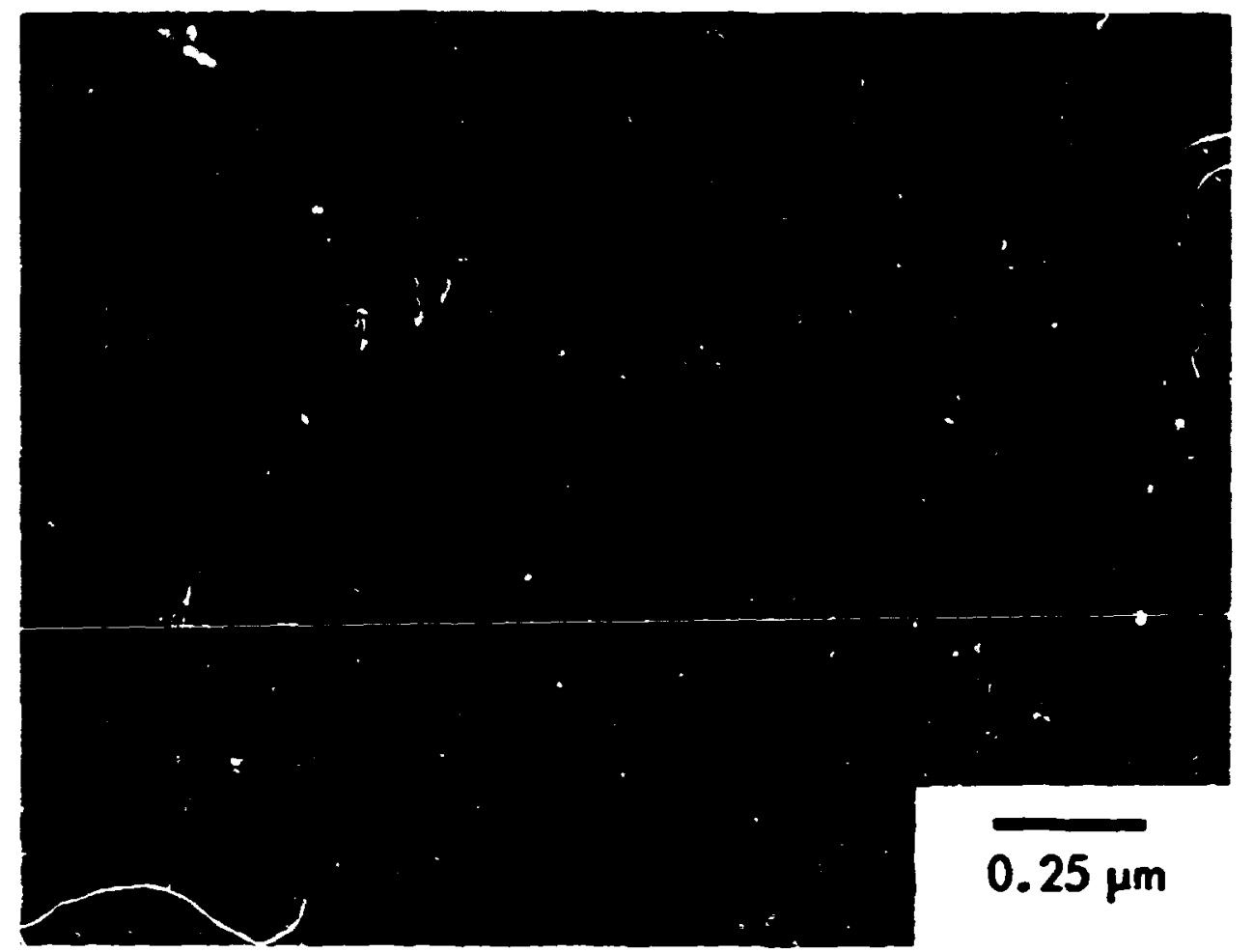

Pigure 5. Plate-like precipitates formed in type 304 stainless steel during irradiation at $371^{\circ} \mathrm{C}$.

E. E. Bloom, W. R. Martin, J. 0. Stiegler, J. R. Weir, "The Effect of Irradiation Temperature on the Strength and Microstructure of Stainless Stee1," I. Nu.c1. Mat1. 22, 68 (1967).

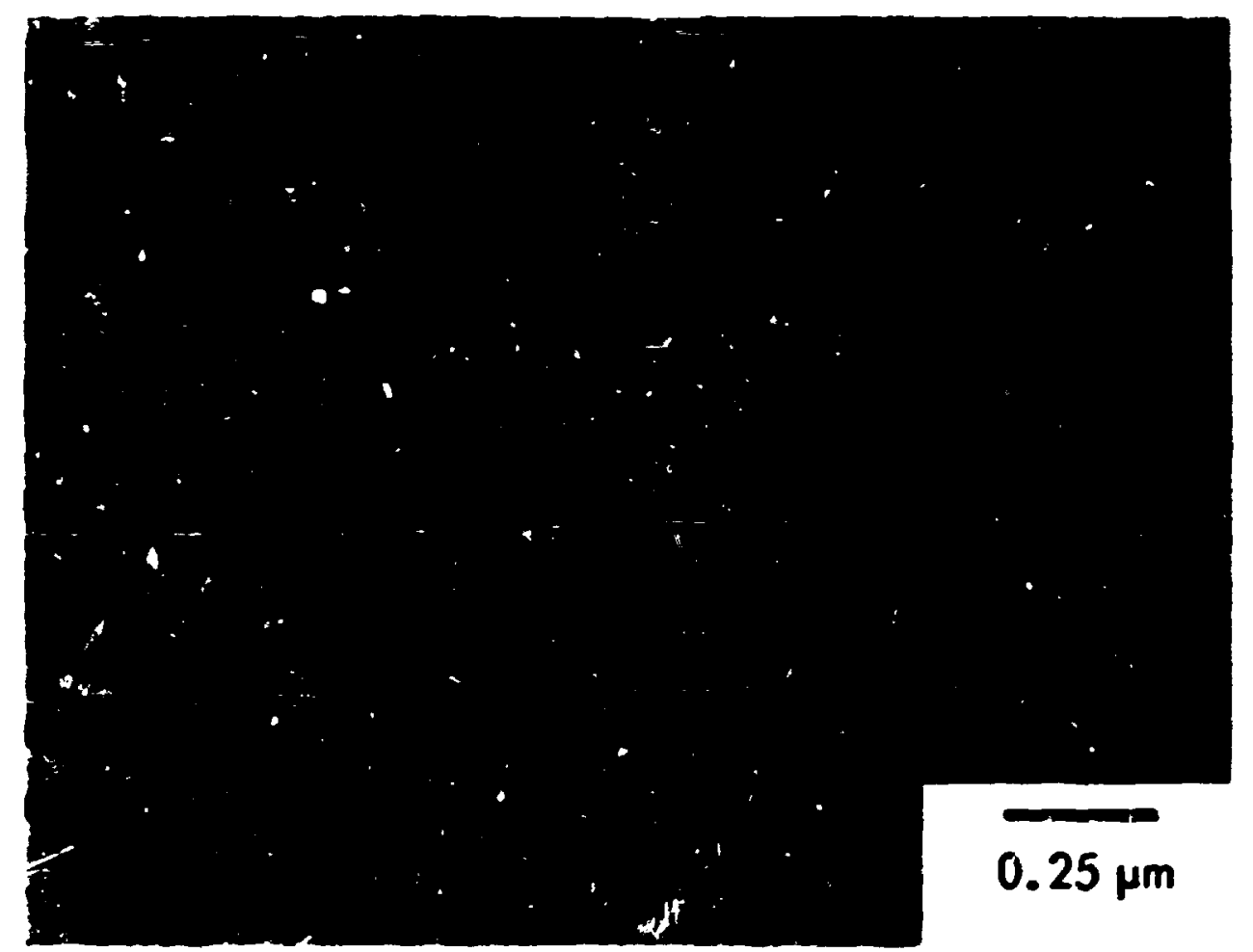

Fjgure 6. Precipitates, with a denuded zone adjacent to the grain boundary, formed in type 304 stainless steel during irradiation at $454^{\circ} \mathrm{C}$.

E. E. Bloom, W. K. Mart1n, J. O. Stiegler, J. R. Weir, "The Effect of Irradiation Temperature on the Strength and Microstructure of Stainless Steel," J. Nucl. Matl. 22, 68 (1967). 
irradiated at temperatures between 350 and $560^{\circ} \mathrm{C}$ to fast neutron fluences as high as $7.8 \times 10^{22}$ neutrons/ $\mathrm{cm}^{2}$. The volds ranged in size from the sallest observable (approxinately $50 \mathrm{~A}$ ) to $1100 \mathrm{~A}$ in dianeter. The total void volume Increased with incressing fast-neutron fluence and appeared to be a maximu for irradiation at approxinateiy $510^{\circ} \mathrm{C}$. The vold volume could not be accounted for solely in terms of helium production since the ancunt of hellum required to balance the surface teasion by an Internal pressure was as wch as 100 times that produce-1 by transmutacion reactions. The number of voids was greatly reduced by postirradiation annealing for $1 \mathrm{hr}$ at $900^{\circ} \mathrm{C}$ sind the residual vold volume was reasonably consistent with the amount of hellum expected from transmutation reactions.

These reaults have been confirmed and extended by a number of investigators $(51,52,53,54)$. Holmes et a‥ (51) and Claudson et al. (52) have exanined type 304 stainless steel which had been irradiated in the EBR-II at temperatures between $37 \mathrm{C}$ and $47 \mathrm{C}^{\circ} \mathrm{C}$. Volds and loops (thought to be interstitial in asture) were observed. The volds were unffocmly listributed except for a denuded zone near grain boundartes. The vold concentration increased as the fluence raised to the $1.2 \pm 0.3$ power and no relatiocuhip between vold concentration and irradiation temperature was reported. The vold size increased with irradiation temperature and to a lesser extent with neutron flvence and, at least the higher Irradiation temperature $\left(472^{\circ} \mathrm{C}\right)$, the volds were predoninately octahedral La shape with surfaces on $\{111\}$ planes and the ends truncated by $\{100\}$ planes. 
jt1Eglei and Bioon (53) exanined type 304L stainless steel Irradiated at temperatures between 370 and $470^{\circ} \mathrm{C}$ to neutron fluences in the range of 0.8 to $1.4 \times 10^{22}$ neutrons $/ \mathrm{cm}^{2}$. After irradiation at $370^{\circ} \mathrm{C}$ to $0.8 \times 10^{22}$ neutrons $/ \mathrm{cm}^{2}$ (E > $0.1 \mathrm{MeV}$ ) both 1 sops and volds were present. The loops ranged in diaseter fron the snallest observable to approxinately 50n A dianeter. W1th increasing irradiation temperatures the loop concentration decreased and the size increased. After irradiation at $472^{\circ} \mathrm{C}$ to $0.9 \times 10^{22}$ neutrons $/ \mathrm{cm}^{2}$ ( $\mathrm{E}>0.1 \mathrm{HeV}$ ) the loope had diameters of approxtmately 100 to $1100 \mathrm{~A}$, were on $\{111\}$ planes and were faulted. This suggested that they were Prank sessile 100ps. The voids appeared to be homgeneously distributed and ranged in size frow the smallest observable to approxdmately 190 and 310 A after Irrsilatiess at 370 and $470^{\circ} \mathrm{C}$, respectively. Histograss of the vold alze distributions were deternined. In gezeral, the histogram had a bell ahape. In this Investigation, a wide variety of vold shapes was observed. The analler volds appeared spherical in shape. The larger volds often had faceted or crystallographic surfaces; however, few of these were regular polyhedra and many were very irregular in shape. A chiracteristic observed by all Investigators has been the absence of rolds on grain boundaries. This Is important since, if the volds were bubbles stabilized by an squilibrium pressure of a gas such as hellum, they would be present at the gratn bcuadaries as well us in the matrix.

The density decrease associated with the fcrmation of volds in type 304 stainless steel has been wasured by several investigators $(2,52,54,55)$ and the reaults were recently tabulated and disctsesed by 
Claudson et 르. (52). Neariy all paluve were from specinane Irradiated at temperatures between 370 and $470^{\circ} \mathrm{C}$, and over this range of texperature the data were fit to an expression:

$$
\frac{\Delta p}{\nu_{p}}[(t t), I]=6.5 \times 10^{-39}(\phi t)^{1.77} \exp \left(-\frac{5600}{R T}\right)
$$

where

$$
\begin{aligned}
& \frac{\Delta \rho}{\rho_{0}}=\text { density decrease, } \\
& (\phi t)=\text { fast neutron fluence in neutrons/ } \mathrm{cm}^{2}(E>0.1 \mathrm{KeV}) \text {, and } \\
& \mathrm{g} \text { and } \mathrm{I} \text { have their usun meanings. }
\end{aligned}
$$

The effect of temperature on the formation of volds and dislocation loops is not well known for temperatures above $470^{\circ} \mathrm{C}$. Barkness eㅡ all. (54) heve reported that no volds or loops were observed in type 304 stainlese steel irsadiated at $600 \pm 50^{\circ} \mathrm{C}$ to $2.4 \times 10^{22}$ neutrons $/ \mathrm{cn}^{2}$. Aithough it is now well established that volds are forsed in stainlese steel as a result of fast neutron Irradiation in the tenperature range of 370 to appreicinately $600^{\circ} \mathrm{C}$ the prectse mucleation and groulh machanteas are not known.

Several machantsas have been proposed to explatn how vold mucleation aght occur. Since there is continuous production and annihilation of vacancies during Irradiation, the vacancy concentration In the lattice w11 exceed the thernal equilibriun concentration. If this vacancy supersaturation ts sufficient, homogeneous nucleation san occur. The critical supersaturation for hosogeneous nucleation, $\left(C_{v} / C_{v_{0}}\right), 18$ related to the critical vold radius $R_{v}^{*}$ by: 


$$
C_{\nabla} / C_{v 0}=\exp \left(2 \gamma R / R_{v}^{k} k r\right)
$$

where

$$
\begin{aligned}
& C_{v}=\text { actual vacancy concentration, } \\
& C_{v o}=\text { vacancy concentration in thermal equilibriu, } \\
& Y=\text { surface energy, } \\
& \Omega=\text { atonis volune, } \\
& k=\text { Boltzan's constant, and } \\
& T=\text { temperature in } \cdot R .
\end{aligned}
$$

Beeler (56) has suggested that vold nucleation nay occur by the overlapping of displacenent cascades. If a second cascade occurs in the very close vicinity of an inftial cascate before the high vacancy concen-tration present in the center of the inftial cascade is elfininated, a vold having radius $R_{V}^{*}$ in equilibriu with the exdsting vacency supersaturation way be formed.

Carthorne and Fulton $(1,2)$ have suggested that hellu from $(n, a)$ reactions esy stabilize saall ebryo (1.e., volds having a radius $R_{v}$ 1 ess than $R_{v}^{*}$ ) thus providing nuclef for subsequeat precipitation of vacancies.

Barkness and $\mathrm{LI}$ (54) have recently published a theoretical trearwent of the vold formation phenosenon. Vold nucleation was assuned to oscur in vacancy rich reglons created within dioplacemant opikes. Growth was assumed to occur by the precipitation of vacancies from a spersaturated solution with the growth rate controlled by vacancy diffuston. A sumary of the work of Hartness and LI (54) follows. 
The free energo change $\left(\Delta G_{v}\right)$ associated with growth of a spherical cavity by an enount dR 18 given by:

$$
\Delta G_{v}=-4 \pi R_{v}^{2} d R_{v}\left(P_{B}+\sigma+\mu_{v} \frac{\rho}{M}\right)+8 \pi r_{v} d R_{v}
$$

where

$$
\begin{aligned}
& P_{8}=\text { interni gas pressure, } \\
& R_{\mathbf{f}}=\text { cavity radius, } \\
& \sigma=\text { hydrostatic stress, } \\
& \rho=\text { density of metal, } \\
& Y=\text { molecular weight of netal, } \\
& \mu_{v}=\text { chenical potential of vacancy, and } \\
& Y=\text { surface energy. }
\end{aligned}
$$

The chenteal potential of a vacancy is assured to be expressed as

$$
\mu_{v}=E_{v}+k T \ln C_{v}
$$

where

$$
\begin{aligned}
& \mathbf{E}_{\mathbf{v}}=\text { energy of vacancy formation, } \\
& \mathbf{C}_{\mathbf{v}}=\text { vacancy concentration, } \\
& \mathbf{T}=\text { temperature, and } \\
& k=\text { gas constant. }
\end{aligned}
$$

Since

$$
E_{v}=-k T \text { ln } C_{v 0}
$$

where $C_{\text {vo }}$ - thermal equilibrium vacancy concentration at temperatire, $T$, :q. (18) car be rewritten as: 


$$
\mu_{v}=k T \ln \left(c_{v} / C_{v o}\right)
$$

Eq. (17) thus becomes

$$
\Delta G_{v}=-k T \frac{\rho}{Y} \ln \left(C_{v} / C_{v 0}\right)-P_{g}-\sigma+\frac{2 Y}{R_{v}}
$$

when divided by $4 \pi R_{v}^{2}$ dR to give the free energy change per unit volume. Harkness and $\mathrm{LI}$ ottain the steady state vacancy concentration by using the treatment of Greewrood et al. (57). They assumed that the nost effective sink for the irradiation produced vacancies and interstitials is the dislocation network. The steady state vacancy concentration is then given by:

$$
\left(C_{v}-C_{v 0}\right) D_{v}=(1 / 4) B r_{1}^{2}\left[2 \ln \left(r_{1} / r_{0}\right)-1\right] \ldots
$$

where

$$
\begin{aligned}
& D_{\nabla}=\text { vacancy diffision coefficient, } \\
& B=\text { net creation rate of vacsncies or interstitials, } \\
& I_{1}=\text { disiocation spacing, and } \\
& r_{0}=\text { dislocation core radius. }
\end{aligned}
$$

The net creation rate of point defects, $A$, is obtained by estinating the number of vacancies and interstitials that recombine during their migration toward dislocations. The probabifily of recomination is given by

$$
1-\exp \left(-10 C_{v} v_{1} \tau\right)
$$


and, thus, $B$ is given by

$$
B=B^{\prime} \exp \left(-10 \tau_{v_{1}}{ }^{\prime} \tau\right)
$$

where

$$
\begin{aligned}
& B^{\prime}=\text { actual defect generation rate, } \\
& v_{1}=\text { interstitial fump freq̧uency, and } \\
& r=\text { average interstitial lifetime. }
\end{aligned}
$$

Following the development given by Greenwood et al. (57) che expression for the steady state vacancy concentration is:

$$
\begin{aligned}
C_{v}-C_{v 0}= & B^{\prime} r_{1}^{2} / D_{v}\left[1 / 2 \ln \left(r_{1} / r_{0}\right)-1 / 4\right] \exp \\
& {\left[-10\left(D_{v} / B^{\prime} a^{2}\right) C_{v}\left(C_{v}-C_{v 0}\right)\right], }
\end{aligned}
$$

where a 18 the lattice spacing.

Harkness and $L 1$ assumed that the nucleation occurs in displacement spikes and that this nucleation process had the same temperature dependency as homogeneous nucleation. The number of nuclef reaching critical size per unit time, $N_{c}$, is given as:

$$
H_{c}=K_{1} \phi \exp \left(-16 \pi \gamma / 3 k T \Delta G_{v}^{2}\right)
$$

where $K_{1}$ is a constant and $\phi$ is the neutron flux. The neutron flux appears in the equation since nucleation 18 assumed to ocrur in the displacement spikes. The nucleation mte $\dot{I}$ is the product of the concentration of critical size nuclel (Eq. 26) and the rate at which 
vacancies are added to these nuclet, which is proportional to $\exp \left(-\Delta t_{\mathbf{R}} / \mathrm{RT}\right)$, where $\Delta G_{m}$ is the energy for vacancy diffusion. The final expression for the nucleation rate is then given by:

$$
\dot{I}=R \phi \exp \left(-16 \pi \gamma^{3} / 3 k T \Delta G_{v}^{2}\right) \exp \left(-\Delta G_{n} / k T\right)
$$

where $K$ is said to be a slowly varying function of temperature. The riscleation rate caliulated from equation 27 is plotted as anction of temperature in Figure 7.

In the model of Harkness and $\mathrm{LI}$ void growth is assuned to occur by the precipitation of vacaicles from supersaturated solution and is controlled by the rate at which vacancies can diffuse to the vold surface. The growth rate $\dot{G}$ is given by the equation

$$
\dot{G}=d R_{\nabla} / d T=a D_{v} C_{v} / R_{v},
$$

where

$$
\begin{aligned}
& \alpha=\text { constast }(\div 1), \text { and } \\
& R_{v}=\text { void radius. }
\end{aligned}
$$

Harkness and Li integrate inis expression between some nucleation time, $t_{0}$, and time, $t$, and obtain:

$$
R_{v}=\left(\alpha D_{v} c_{v}\right)^{1 / 2}\left(t-t_{0}\right)^{1 / 2}
$$

If this expression 18 substituted into equation 23 the growth rate 18 


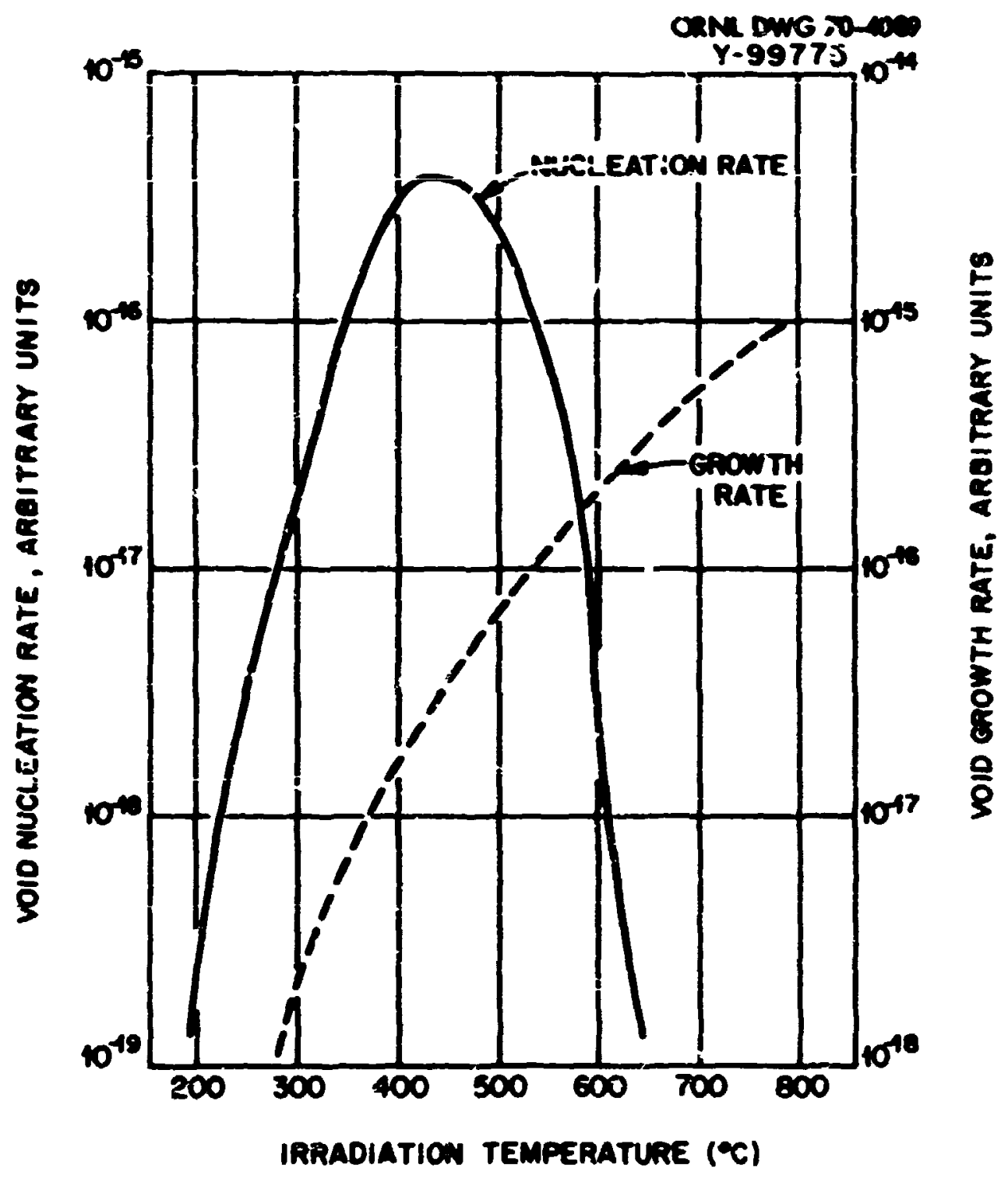

F1gure 7. Temperature dependence of the rates of vold nucleation and vold growth in type 304 stainless steel Irradiated In EBR-II as calculated by the wodel of barkness and $L I$.

S. D. Harkness and Che-Yu L1, "A Model for Vold Pormation in Hetale Irradiated in a Past-Neutron Enviroment," p. 189 in Radiation Denage in Reactor Materials, Vo1. 2, International Atomic Energy Agency, VIenna, 1969. 


$$
\dot{G}=\frac{d R_{v}}{d t}=\left(\alpha D_{v} C_{v}\right)^{1 / 2} /\left(t-t_{0}\right)^{1 / 2}
$$

The temperature dependence 18 proportional to $\left(D_{\nabla} C_{v}\right)^{1 / 2}$.

The vold volume fraction or density decrease was obtained from the Johnson-tehl (58) expression, which gives $\bar{F}$, the fraction transformed (1.e., the vold volume) as a function of the nucleation and growth rates:

$$
\bar{F}=1-\exp \left[-\operatorname{xI}\left(D_{v} C_{v}\right)^{3 / 2} t^{5 / \bar{z}_{j}}\right]
$$

For the susll volwe fractions which occur as a result of rold formation the density decrease should follow a $t^{5 / 2}$ dependency. Bquation 31 is plotted as a function of temperature at a constant fluence in P1gure 8 and as a function of fluence for several temperatures in Figure 9. An eapirical spproach to the deternination of rechanises controlIng swelling was taken by Claudson et al. (52) who exanined the flux and time dependence of the volume change which would occur if any combination of five pcssible nucleation mechanisms or seven growth sechaniess controlled the density decrease. The nechanian which gave best agreenent with experinental results was nucleation in displacesent spikes and the growth of faceted volis by vacancy absniption at their tips.

Recent experimental results of Lauritzen et aㅡ. (59) and Blooa and Stiegler (60) have Indicated that compositional differences such as those which exist beiween types $304,316,321$, and 347 stainless steels can have a marked influence on Irradiacion Induced vold formation and owelling when the ricrostructures in these alloys are coupared at a 


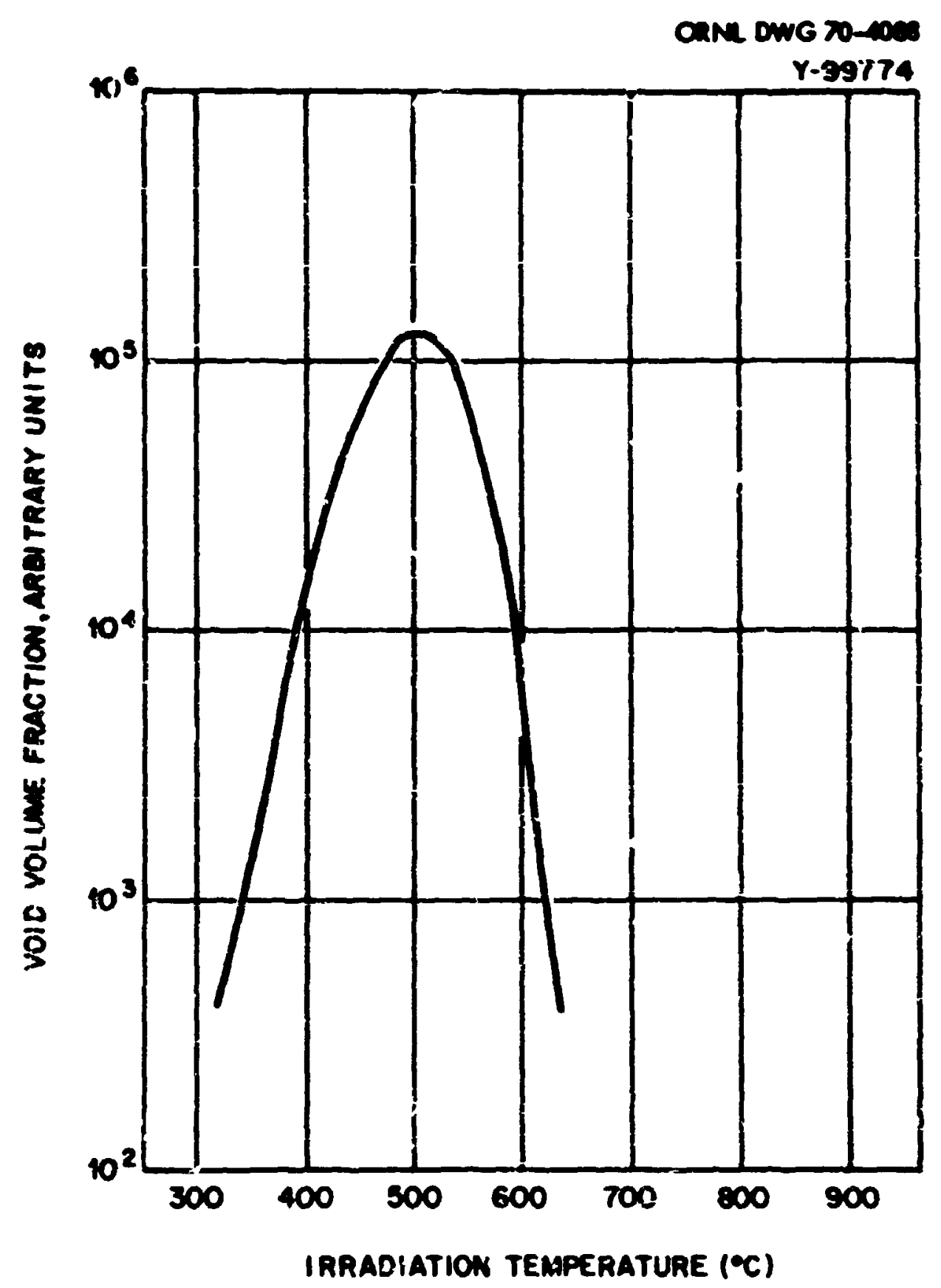

Figure 8. Predicted temperature dependence of vold formation from model of Harkness and L1.

S. D. Harkness and Che-Yu L1, "A Model for Vold Formation in Metals Irradiated In a Fast-Neutron Environert," p. 189 in Radiation Damage in Reaclor Yateriale, Vol. 2, International Atonic Buergy Agency, Vienna, 1965 . 


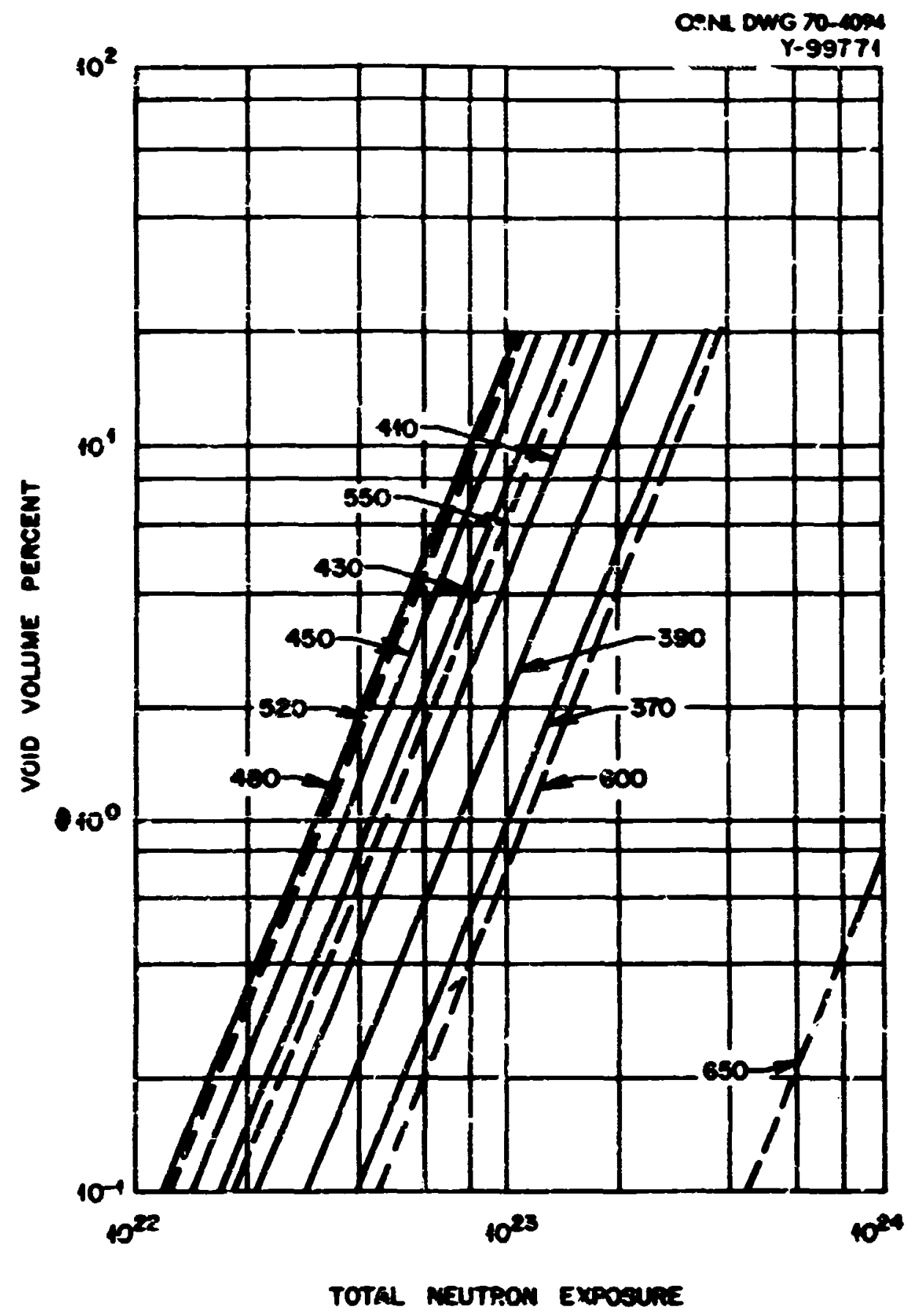

Figure 9. Expected vold volume as a function of terperature and fluence from wodel of Harkness and LI.

S. D. Harkness and Che-Yu L1, "A Hodel for Vold Fornation In Metals Irradiated in a Fast-Neutron Envirumment," p. 189 In Radiation Damage in Reactor Materials, Vo1. 2, International Atontc BnergJ Agency, Vienna, 1969. 
common irradiation teaperature and fluence. The reasons for these differences are not understood, and, because of the limited amount of data, Jefinite trends regarding differences in temperature and fluence dependenc..es cannot be established. These results do, however, indicate the importanse of minimizing the composition variations when attempting to examine ott er variables such as temperature, neutron flux and neutron fluence.

Examination of the published literature indicates that although some information exists regarding the irradiation induced density change, only a few detailed nicrostructural exarinations have been reported. The details of the dependence of irradiatinn-induced void formation on temperature, fluence and material parameters are lacking. The model developed by Harkness and $\mathrm{LI}(54)$ is able to predict irradiation induced density changes since nearly all of the parameiers in the modsi are adjusted on the basis of density change data. This same model, however, does not agree with several experimental observations. For example, the model predicts (Pigure 7, page 36) that the veid concentration at a ccrstant fluence should increase as the irradiation temperature is increased, reaches a maximum at approximately $450^{\circ} \mathrm{C}$, and then decrease with further Increases in temperature. Experimental resulti of Claudson et al. show the vold concentration to be independent of irradiation temperature. The model of Harkness an? Li indicates that helium plays no role in the vold nucleation or growth, yet results obtained by Nelson and Mazey (61) indicate that helfum may be important in the void nucleation step. 
The present investigacion was inftiated to investigate more thoroughly the temperature, fluence, anc flux decendence of the irradiation-snduced void and loop formation phenomena in austenitic stainless steels and to attempt to define the operative vold nucleation and growth mechanisms. 
CRAPTER IV

EXPERTMENTAE PROCEDURE

The experimental variables of irradiation temperature, fast neutron fluence, fast neutron flux, and neutron energy spectrum ay be important in controlling the aicrostructural changes which occur in metals and alloys when subjected to neutrcn irradiation. In order to investigate the effect of these variables in austenitic stainless steels over as wide a range as possible, materials from two sources were used. The first source incluiled components that had been removed from the Experimental Breeder Reactor-II (BBR-II). During irradiaiton there was a gradient in both temperature and neutron flux along thi:: length. The second source Included spectmens which were irradisted in the EBR-II in experimental subassemblies. Since these irradiation experinents had design-controlled temperatures a wider range of experimental variables was obtained.

Postirradiation examination incluaed immersion density measurements and transwission electron microscopy (TEM).

\section{DESCRIPTION OF RRACTOR COMPOHENTS}

The reactor components used in this investigation were (1) the cladding from an EBR-II driver fuel element (Driver Fuel Element No. C-179-86), (2) a shroud tube which was removed from a 19 pin experimental subassembly (Subassembly $x \mathrm{CO}$ ), (3) a contatnment tube which was removed from a 7 pin experimental subassembly (Subassembly x0-67), and (4) a 
portion of an EBR-II safety rod thimble (Safety Rod Thimble 3-D-1 flat C). The components were made of AISI Type 304 stainless steel. The chemical analysis and exsct thernal-mechanical history of each of the components prior to its irsaciation in the BBR-II could not be ascertained. The compusition of some typicai unirradiated components, no: necessarily from the same heat as the irradiated cumponents, are listed in Table II. The microstructures of material taken from an unirradiated fuel cladding and a safety rod thimble are shown in Figures 10 and 11. These materials should have received sinflar thermal-mechanical treatJents as was received by the respective irradiated craponents prior to their insertation into the EBR-II. The average grain diameter of the fuel ciadding and safety rod thimble as determined by the intercept technique was 0.016 and 0.045 respectively.

The fuel cladding was a tube, $44 \mathrm{~cm}$ iong, $0.40 \mathrm{~cm}$ inside dianeter and an $0.023 \mathrm{~cm}$ wall thickness. During irradiation in the core of the EBR-II (know 2), the outside of the cladding was exposed to flowirg sodiu containing 10 to $15 \mathrm{ppm}$ oxygen (by weight) and the Inside was in cuntact with static sodium except for a small portion at the top which was in contact with hellum. The irradiation temperature as a function of position along the length for this particular fuel elesent has been calculated by Cushman (62) and is given in Figure 12. The neutron fluence along the length of the cladding has been calculated on the basis of reastor exposure and is also shown in Figure 12. The maximum fluence, at the reactor midplane, was $1.4 \times 10^{22}$ nautrons $/ \mathrm{cm}^{2}$ (B >0.1 MeV). A brief description of the EBR-II and the method used to calculate the fast 
TABLE II

COMPOSITIONS OF TYPICAL UNIKRADIATED EBR-II COMPONENTS

\begin{tabular}{|c|c|c|c|c|c|c|c|}
\hline \multirow[t]{2}{*}{ Component } & \multirow[t]{2}{*}{$\mathrm{Fe}$} & \multicolumn{6}{|c|}{ Analya1s (We1ght Fercent) } \\
\hline & & C & $\mathrm{Cr}$ & $N_{1}$ & Mn & s1 & $T_{1}$ \\
\hline Fuel CladdIng & Balance & 0.034 & 19.0 & 8.4 & 1.0 & 0.53 & $<0.02$ \\
\hline Safety Rod Thimble & Balance & 0.046 & 19.0 & 9.6 & 1.2 & 0.60 & $<0.05$ \\
\hline & & Mo & $\mathbf{P}$ & $\mathbf{s}$ & B & $\mathbf{N}$ & \\
\hline Fuel Cladding & & 0.12 & 0.023 & 0.013 & 0.0001 & 0.048 & \\
\hline Safety Rod Th1mb1a & & 0.01 & 0.012 & 0.013 & 0.00002 & 0.004 & \\
\hline
\end{tabular}




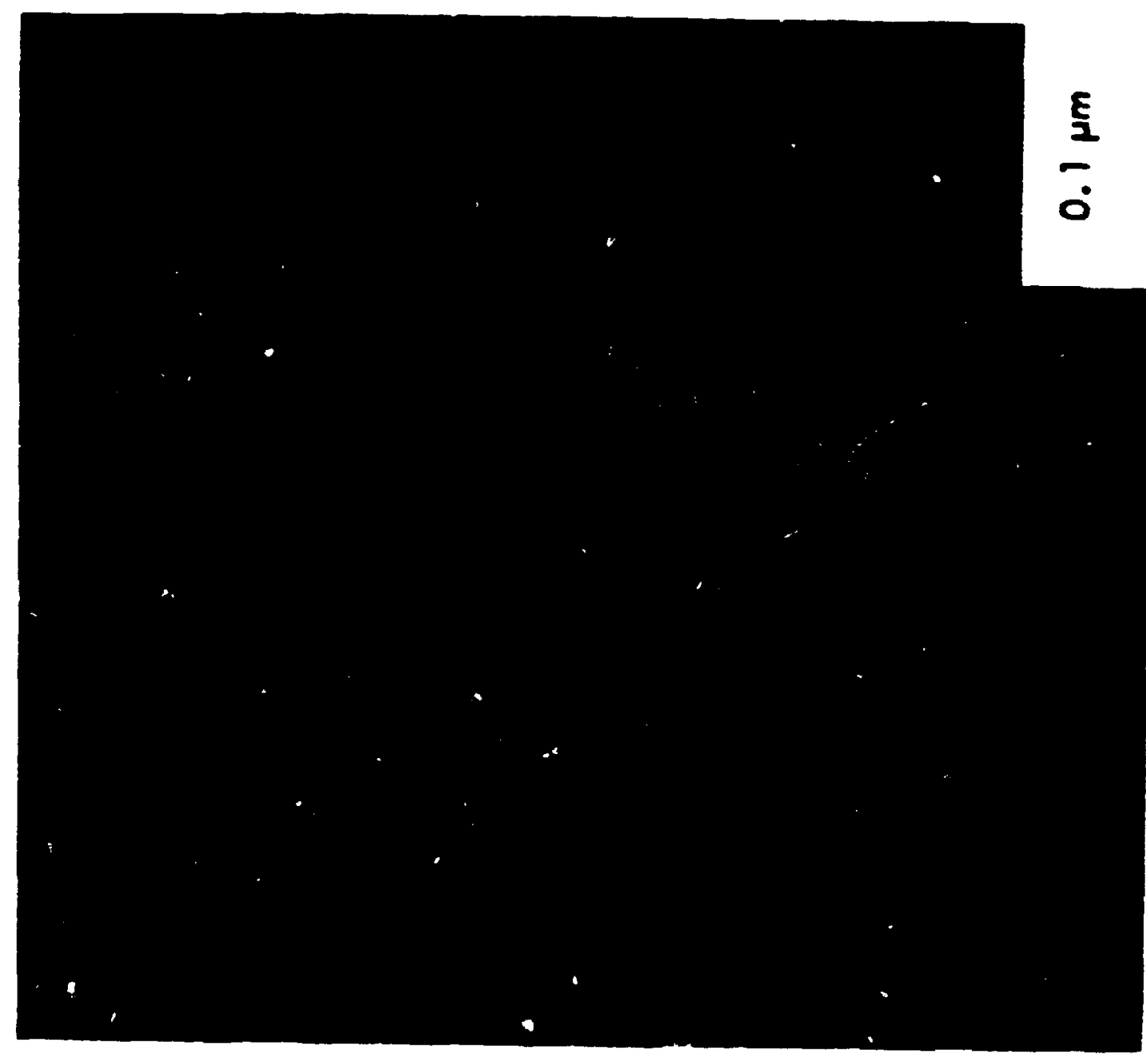

훙

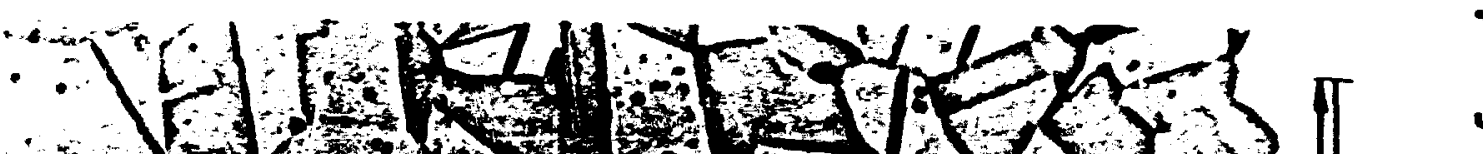

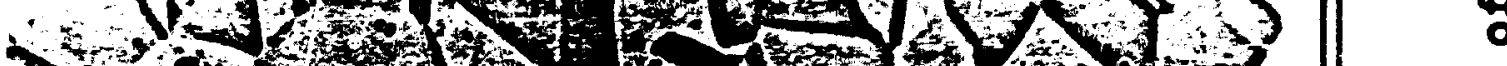

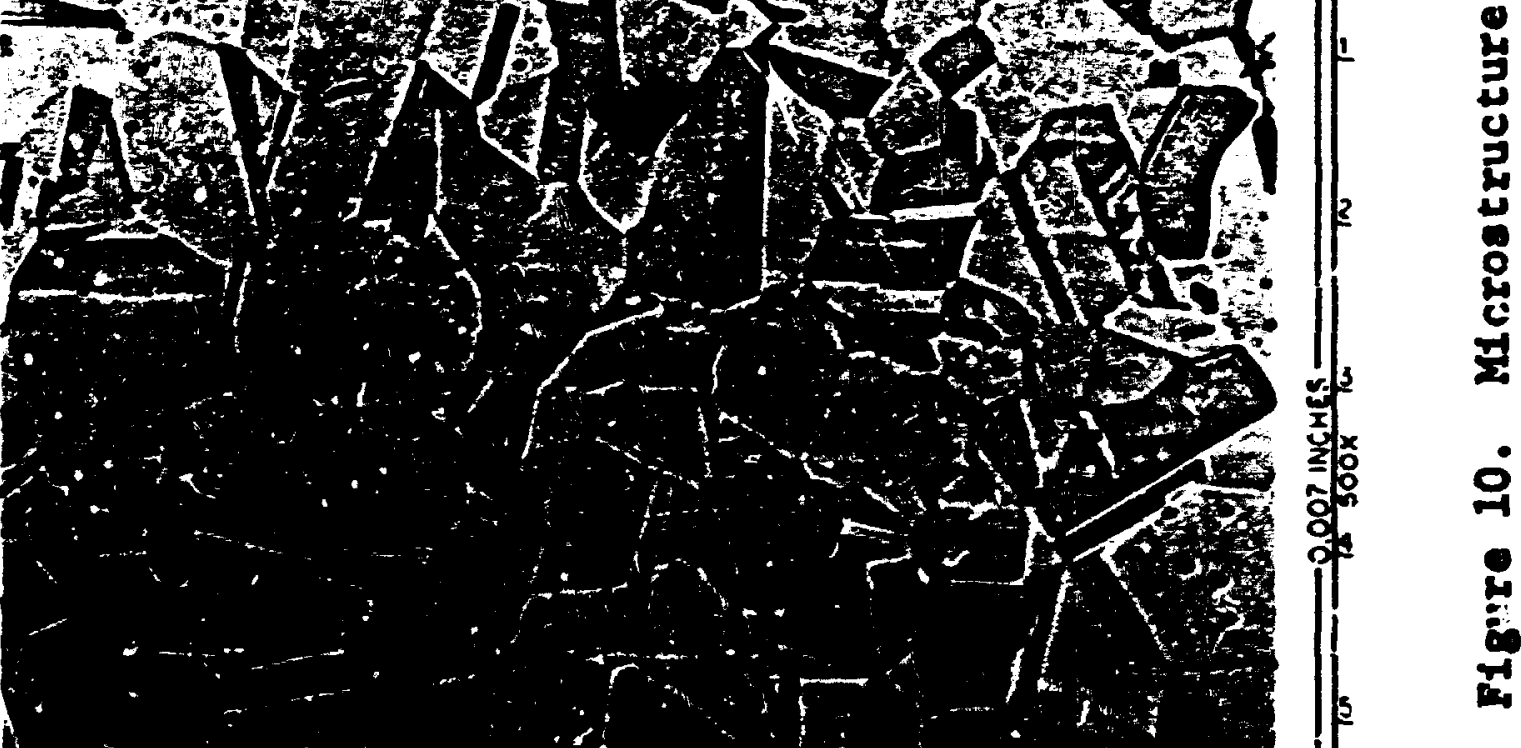



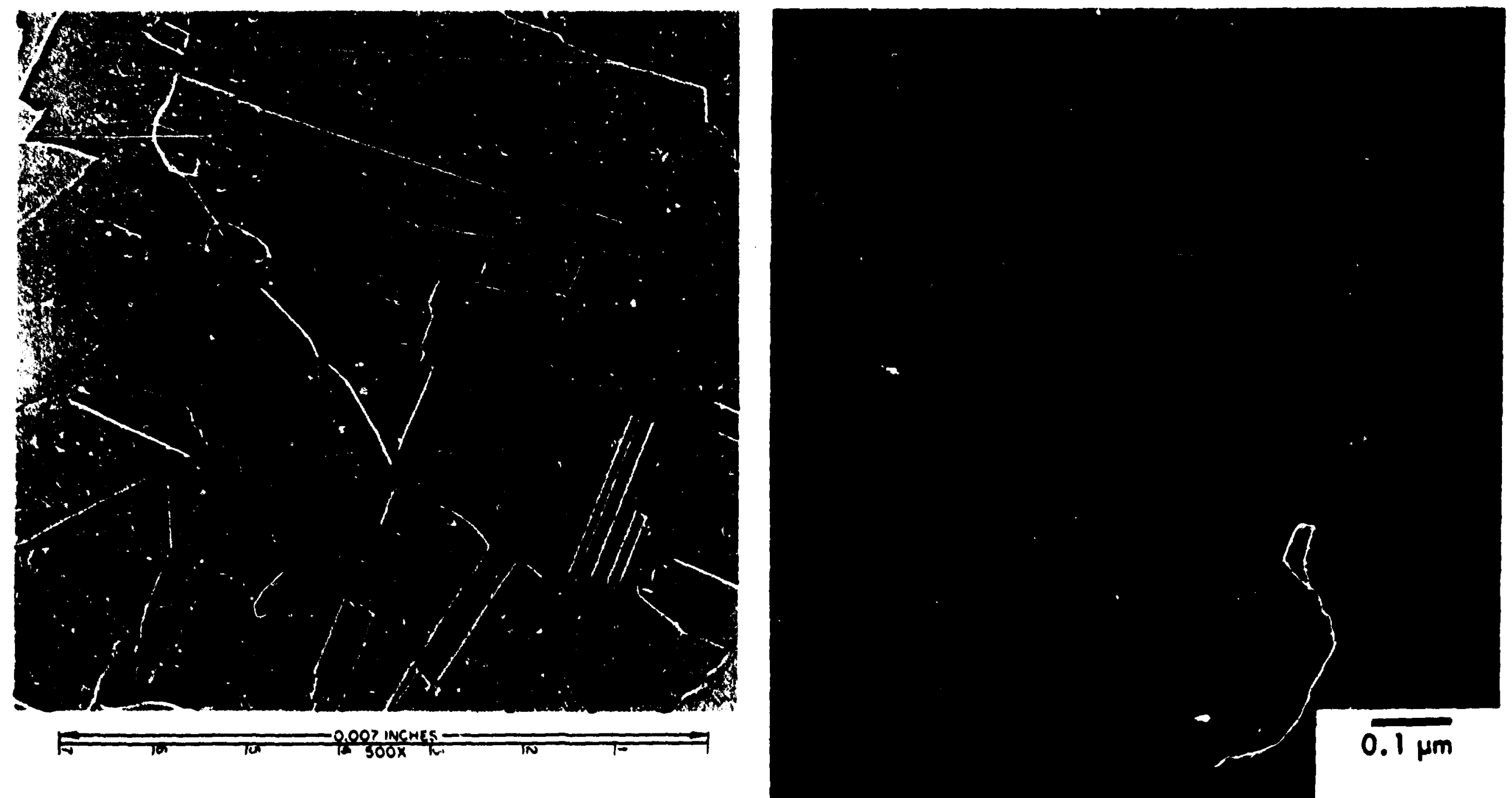

F1gure 11. Microstructure of unirradiated EBR-II safety rod thimble. 


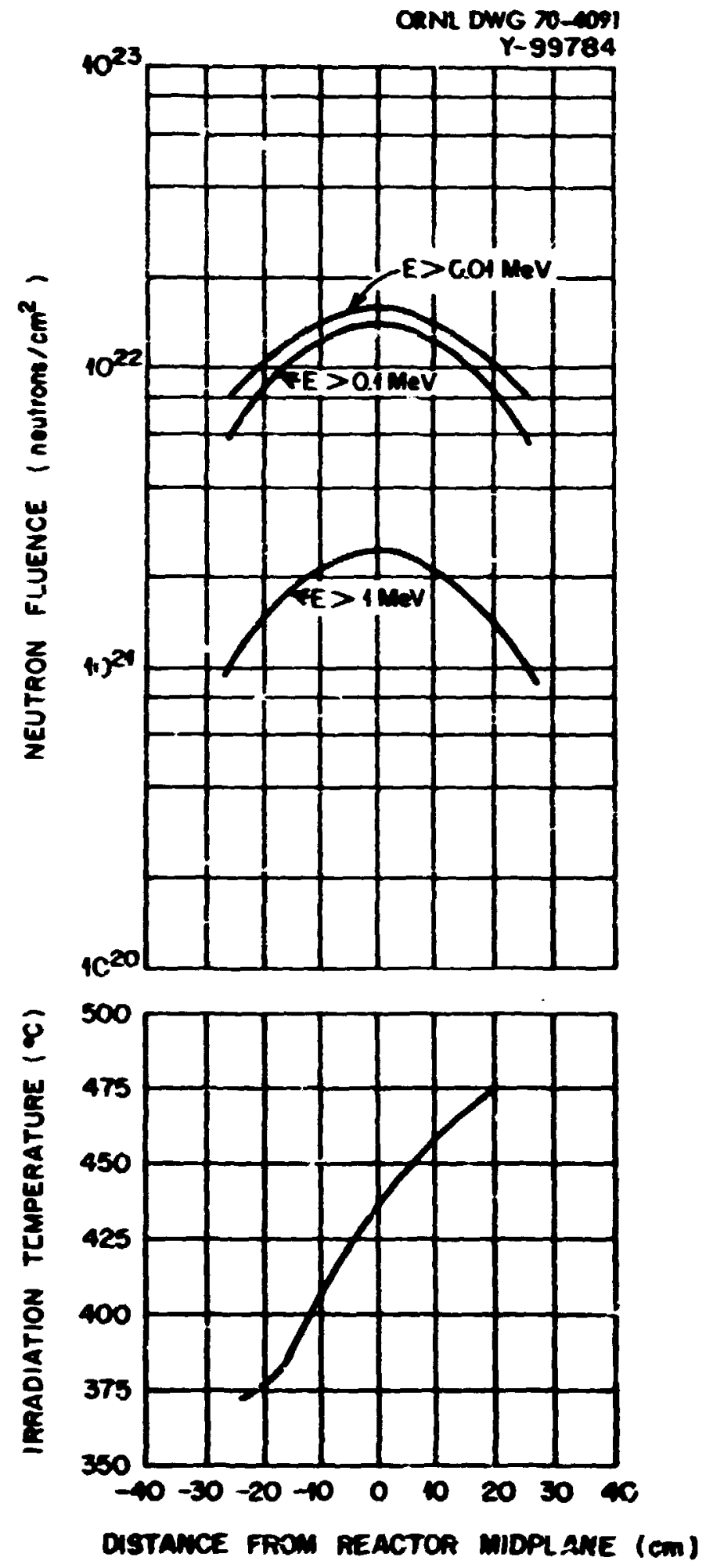

F1gure 12. Irradiation conditions for BBR-II fuel cladding. 
nettron fluence is given in Appendix A. Murphy and Strom (3) have calculated that the internal pressyre in the fuel element (due to fission gas release) at the end of irradistion was $? 0$ to $30 \mathrm{~kg} / \mathrm{cm}^{2}$. This pressure would produce a hoop stress of 2 to $3 \mathrm{~kg} / \mathrm{m}^{2}$ in the cladding.

After irradiation, the fuel was removed from the cladding, and the cladding was cleaned ultrasonically in ethyl alcohol. The cladding was then cut into five sections, each approximately $7.6 \mathrm{~cm}$ long. A $\mathrm{fig}$ was constructed to support the tube wall during all subsecuent cutting operations in orcer to eliminate any deformation and to allow the exact positioning of the cuts. A water-cooled abrasive cutoff saw was used. Four longitudinal cuts were made at 90-deg intervals around the cladding. Transverse cuts at approximately $0.3 \mathrm{co}$ intervals then produced four electron microscopy specimens from any one position (63).

The shroud tube was continged in an experimental subassembly which was Irradiated in a Row + position of the reactor. The shroud tube was $102.5 \mathrm{~cm} 10 \mathrm{ng}, 1.25 \mathrm{~cm}$ inside dianeter, $0.025 \mathrm{~cm}$ wall thickness and extended from the botton of the reactor core to a point $68 \mathrm{~cm}$ above the core. Since there is little heat generated outside the reactor core the coolant teaperature was nearly constant from the top of the core to the top of the shroud tube. During irradiation the tube was not subjected to any appreciable stresses and was exposed to flowing sodium on both the inside and outside surfaces. The calculated irradiaticn temperatures and fast neutron fluences along the length of the shroud tube are shown in Figure 13. 


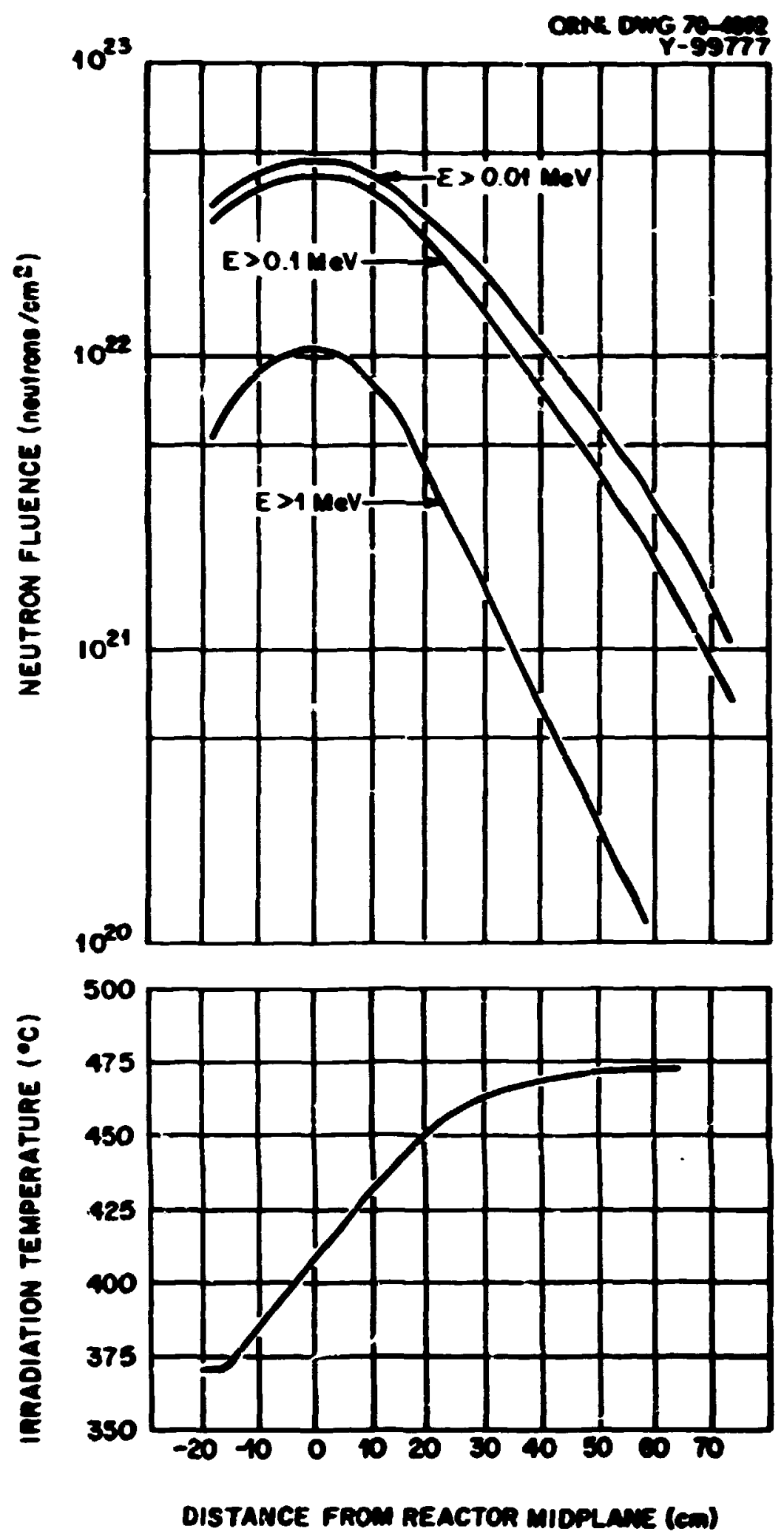

P1gure 13. Irradiation conditions for EBR-II shroud tube. 
Following Irradiation the shroud tube was cleaned and transnission electron wicroscopy specimens were cut in a maner sinilar to that described for the fuel cladding.

The contaiment tube which was resoved from the seven tube experiment subassembly (Subassemly X067) which was Irradiated In a Row 4 position of the EBR-II. This tube had an outside dianeter of $2.05 \mathrm{~cm}$ and a wall thickness of $0.071 \mathrm{~cm}$. Transmission electron nicroscopy specimens were removed fron this component from an area which was approxiately $34.3 \mathrm{~cm}$ below the reactor aldplane during irradiation. The irradiation temperature at this point was $370^{\circ} \mathrm{C}$ and the fast neutron fluence was $2.0 \times 10^{21}$ neutrons $/ \mathrm{c}^{2}$ (E > $\left.0.1 \mathrm{HeV}\right)$.

The safety rod thimble was a hexagonsl shaped tube which was $116.6 \mathrm{~cm}$ long, approxinately $5.82 \mathrm{~cm}$ across each flat and had an $0.10 \mathrm{~cm}$ thickness. The thimble was irradiated in a Row 3 position of the reactor to a peak neutron fluence of $6.75 \times 10^{22}$ neutrons $/ \mathrm{cm}^{2}(E>0.1 \mathrm{MeV})$. Since it extended both above and belor: the core of the reactor there were segments along which the Irradiation temperature was approximately constant at efther 370 or $462^{\circ} \mathrm{C}$ and along which the fast neutron fluence varied. F1gure 14 shows the variation in irradiation temperature and Fast neutron fluence along the length of the thimble. After Irradiation, transmission electron microscopy specimens measuring $0.31 \mathrm{~cm}$ by $0.31 \mathrm{~cm}$ by $0.10 \mathrm{~cm}$ thick and Immersion density specimens measuring $3.08 \mathrm{~cm}$ long by $2.86 \mathrm{~cm}$ wide by $0.10 \mathrm{~cm}$ thick were cut from the desired locations. As with the other components, all cutting operations were done with a water cooled abrasive cut-off saw. 

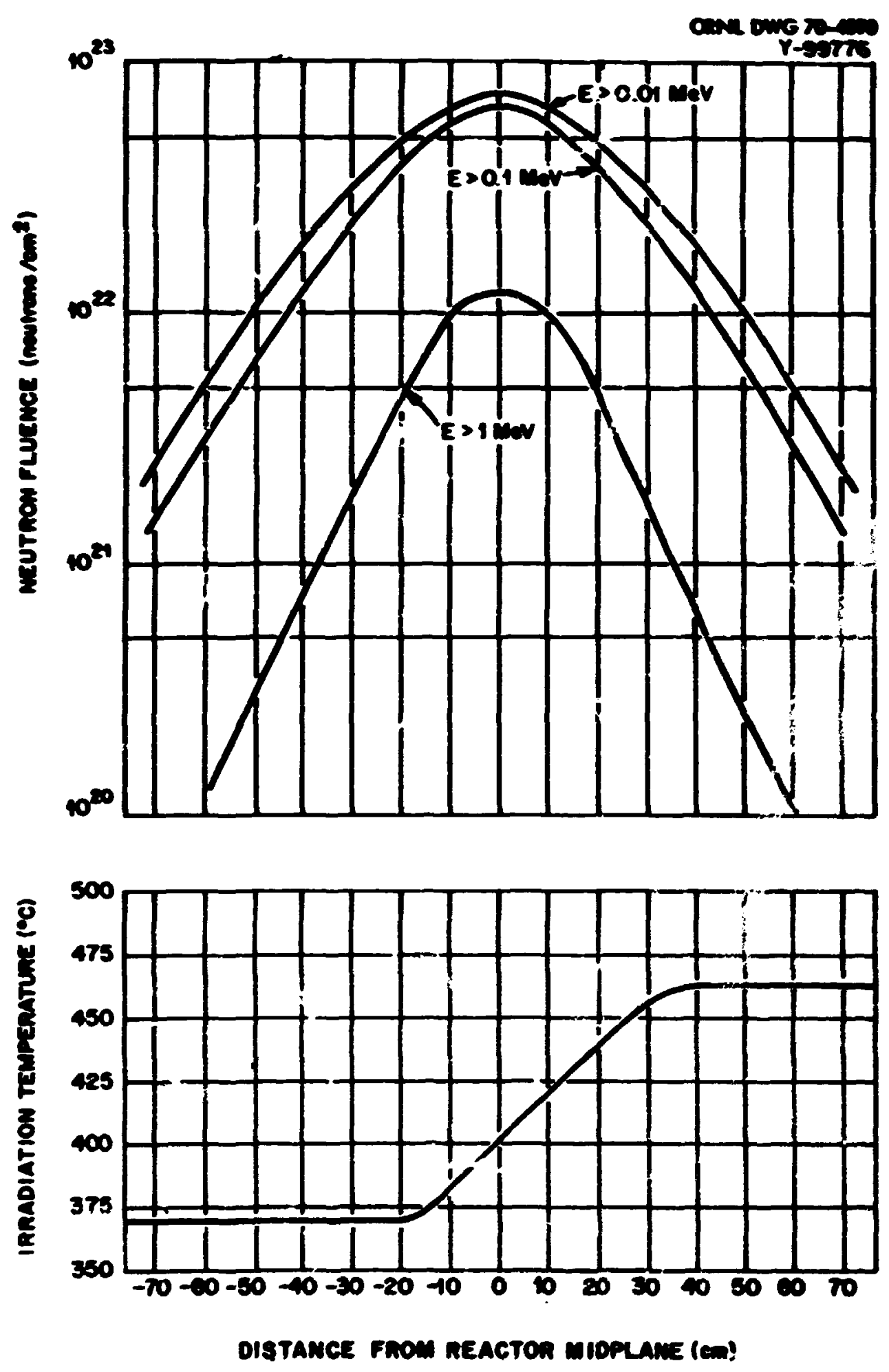

PIgure i4. Irradiation conditions for BBR-II safety rod thible. 


\section{DESIGI OF IRRADIATIOA EXPERIMIENTS}

In order to expand the range of fast neutron fluence and irradiation temerature beyond that avallable through an exainstion of reactor components, specisens were Irradiated in two experimental subassemblies.

In the first experiment, specinens of type 304 stainless 3 teel were Irradiated to neutron fluences of $1 \times 10^{18}$ to $1.4 \times 10^{20}$ neutrons/ $\omega^{2}(\mathrm{~B}>0.1 \mathrm{HeV})$. This experiment was designed in Investigate the Initial stages of the irradiation danage process. Specimens in a second experinent were irradiated as teaperatures of $570-630^{\circ} \mathrm{C}$ and $770-840^{\circ} \mathrm{C}$ to a fluence of $3.7 \times 10^{22}$ neutrons $/ \mathrm{cm}^{2}$ ( $\left.\mathrm{B}>0.1 \mathrm{HEV}\right)$. This experinent was to define the darage structure occurring at the higher Irradiation temperatures.

Bach was designed in a sinilar manner. Spectmens of the design shown In Figure 15, having the composition 11sted in Table III, were held in specimen holders such as the one shown schematically in Figure 16.

A gas gap between the specimen holder surface and the inside surface of the tube element provided a barrier to radial heat flow and allowed temperatures above the reactor coolant temperature to be obtained. The experiment was designed and calibrated on the basis of nuclear heatIng rate as a function of axial position determined in a previous experiment (64).

A computer program was used to calculate the width of the gas annulus between the surface of the specimen holder and the inner wall of the tube. Briefly, the technique was as follows. The materials and 


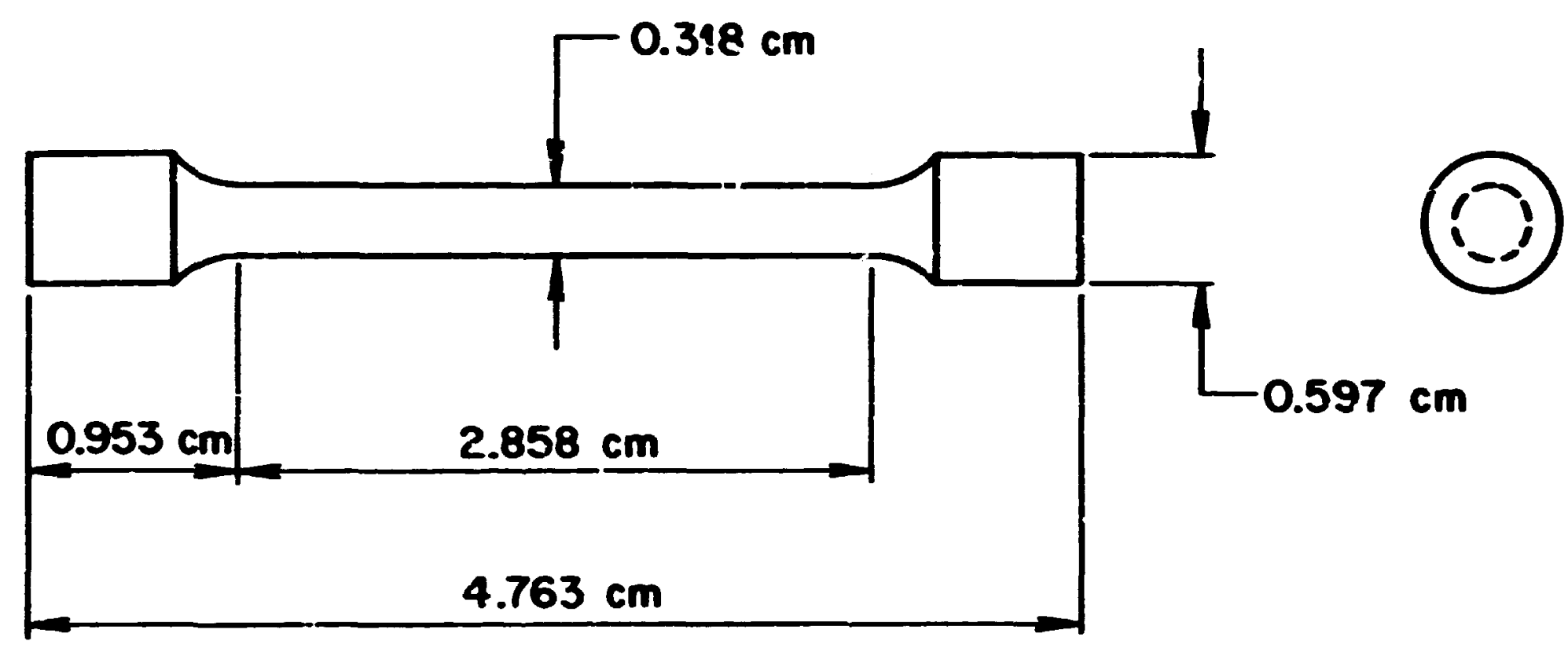

Figure 15. Drawing of specimen used in BuR-II materials irradiation experiments. 
TABLE III

COAPOSITION OF TYPE 304 STAMLESS STEEL USED AI EBR-II MATERIAIS IRRADIATIOA EXPERTIBNTS

\begin{tabular}{lc}
\hline Elenent & Weight Percent \\
\hline C & 0.040 \\
Cr & 18.4 \\
MI & 9.3 \\
S1 & 0.7 \\
Ka & 1.5 \\
S & 0.020 \\
P & 0.012 \\
H & 0.092 \\
B & 0.0008 \\
Pe & Balance \\
\hline
\end{tabular}




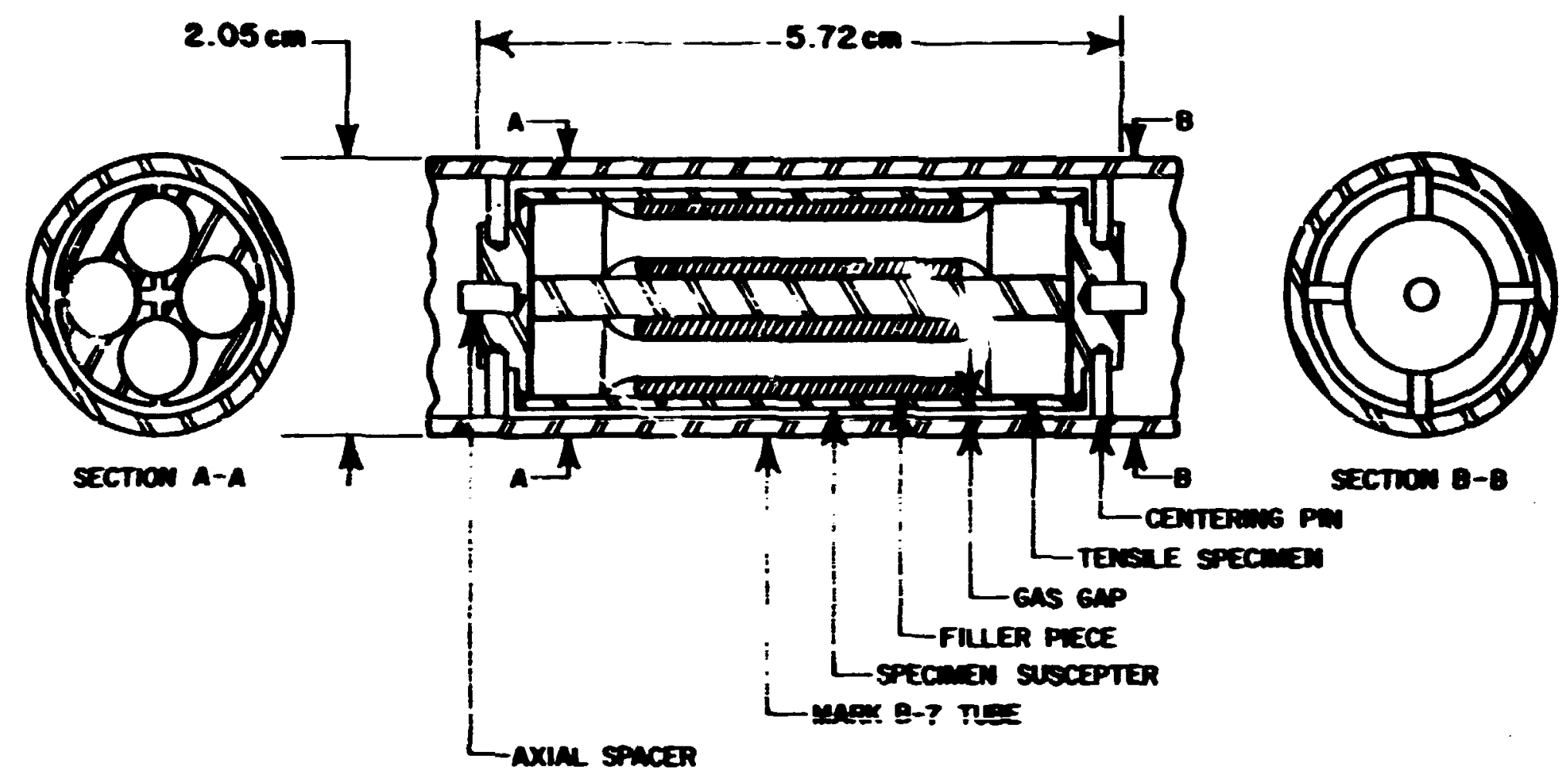

Figure 16. Schenatic drauing of speciwen holder used in BRR-II mterials irradiation experiments. 
desired Irradiation temperature for each specimen bolder within a given tube vere deternined. Inis inforation, the inlet sodiu temerature, sodiu flow sate, a sodtur fill coefficient, the fixed (cold) geometry, the anterial properties such as: enissivity, density, thermal expansion coefficients and theral conductivities as a function of temperature, and the nuclear heating rates as a function of axial position were input to the computer. The computer was programed to calculate the cold 8 as ammilus required to attain the specified irradiation temperatures. Calculations for gas anmulus were perforned at three places (botton, aiddle, and top) on each of the $5.72 \mathrm{C}$ long specimen holders. It was assuned that at steady state all beat transfer within the capsule tube was radial, and that the total heat transferred across the gas annulus was the sum of that transferred by conduction and by radiation. Standard equations applicable to these conditions and geowetry vere used.

During the latter stages of this investigation a second type of irradiation experfinent was conducted in an attempt to denonstrate the Importance of transmutation produced helium in the void formation process. In this experiment sheet spectmens of annealed type 394 stainless steel were Irradiated in the BBR-II in contact with the liquid sodiu reactor coolant. The composition of the alloy was (by weight percent): $\mathrm{Cr}-18.15, \mathrm{MI}-9.60, \mathrm{C}-0.046, \mathrm{Mm}-1.77, \mathrm{SI}-0.62, \mathrm{Cu}-0.25$, Yo $-0.33, \mathrm{Co}-0.03, \mathrm{P}-0.023, \mathrm{~S}-0.010$, Fe - balance. In one set of specinens a uniform concentration of $20 \times 10^{-6}$ aton fraction heliu was Infected prior to irradiation by bombarding with variable energy a particles. The injection was conducted by R. T. King, who ha- described the 
experinental procedure elsemere (65). A second set of unbombarded specinens was irradiated at the sese position in the reactor experineat. The irrodiation teperature, fast neutron flux and neutren eneres opectrus were Identical for the two sets of specineas. The irradiation tenperature was approxdmately $390^{\circ} \mathrm{C}$ and the fluence was $7.6 \times 10^{21}$ neutrons/ $\mathrm{cm}^{2}(\mathrm{~B}>0.1 \mathrm{HeV})$.

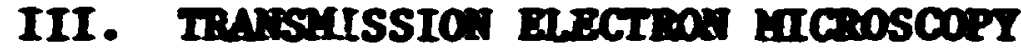

Preparation of spectens for tranedesion electron microscops studies vas accoplished using a sedinutonatic technique which has been described in detall by Dubose and Stiegler (66). The spectnen were first "dimpled" on both sides by an electrolytic jet technique. This reduces the thickness of the specinen to bout $0.08 \mathrm{~m}$ and produces a flat botton dimple. Pinal polishing vas accoplished in an electrolytic cell in which breal through was detected by a photocell device. The

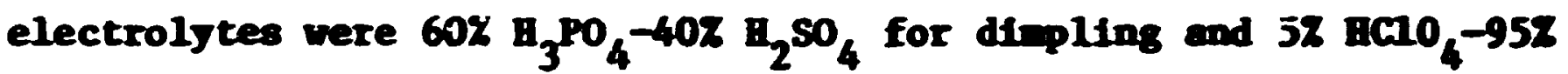
$\mathrm{C}_{2} \mathrm{H}_{5} \mathrm{OH}$ for the final pollshing operation. Only the center of the opectwen remains after thinning by this technique and thrs surface effects which nas have occurred during irradiation are elfinated.

Spectens were exadied on a $200 \mathrm{kv}$ (Hitachi Hu-2003) electron afcroscope. At least two apectwens of each ixradiation condition were exanined. Defect concentrations were daternined by a count of the nuber of defects pex unt area on a photograph and then deterninfor the volum represented by this area through a deternination of the foll thichoes. 
In epeedren Irrodiated to low fast neutron fluences such that the dange was in the forn of anall defect clusters visible only under diffraction condition the foll thichese was nesured by a deternination of the eryotallography of a win bcudary and then searuring the profecthos of the win boundery on the photonicrograph. In all osher instences the foll thichess was measured by obtaining a stero pair of paotoncrographs fron a given area and mesouring the distance between points on the top and botton surfaces of the foll. A discuasion of the variation of the esosured defect concentrations within spectens hrving the sene Irrediation history is given in Appeadix $B$.

\section{I.:asto Dasith rasudratirs}

The exthod osed to deternise the deasity changes which occurred

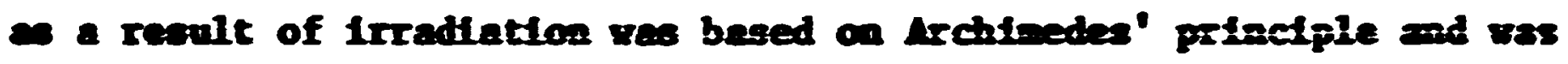
sinflax to the sethod wed by latcliff (67). The denaity o of a saple hwing weight $V_{a}$ in atr of denatey $p_{a}$ ad weight $\nabla_{e}$ in liquid of density pe is given by

$$
\rho=\frac{u_{a} \rho_{e}-U_{e} \rho_{a}}{\eta_{a}-\nabla_{e}}
$$

The densities of irradiated esples $\left(p_{I}\right)$ and of unirradiated amples

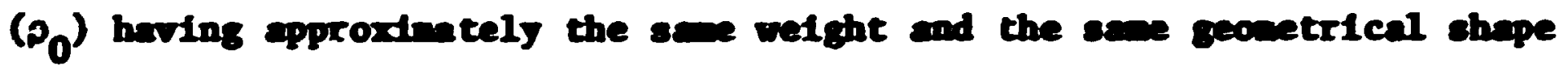
were deterndned by wetghing in atr and in carbon tetrachloside ( $\left.\mathrm{CC}_{4}\right)$. The temperature of the air was constant to within $\pm 5^{\circ} \mathrm{C}$ and the denalty of the atr was assured to be $0.0012 \mathrm{gal} / \mathrm{cm}^{3}$. The denaticy of the 11quid 
was deternined imediately before and imediately after the weighing of a given specten in the 11quid. This was obtalised by weighing a callbrated dum saple in the liquid and calculating the density of the IIquid fron the expression

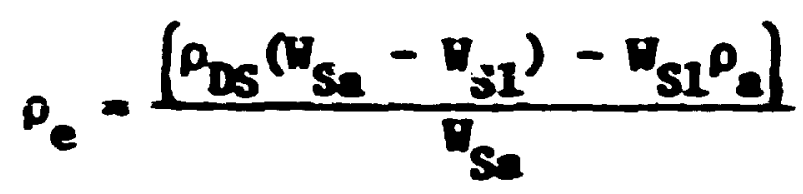

where

$$
\begin{aligned}
& P_{\text {DS }} \text { - densits of calibrated stmaind, } \\
& v_{S a}=\text { weight of standard in afr, } \\
& \text { Y }_{S 1} \text { - weight of stondard in 1iquid, and } \\
& p_{\text {a }}=\text { densits of air. }
\end{aligned}
$$

It was then asouned that the denoity of the liquid at the tire of the weighing of the experimental smple vas the average of the berore and after nesoureneats as deternined bove.

The denotity change which occurred as a result of irradiation, hereafter referred to as $\left(4 p / p_{0}\right)$, was then deterndined from

$$
\frac{\Delta_{0}}{\rho_{0}}=\frac{\rho_{I}-\rho_{0}}{\rho_{0}} \text {. }
$$

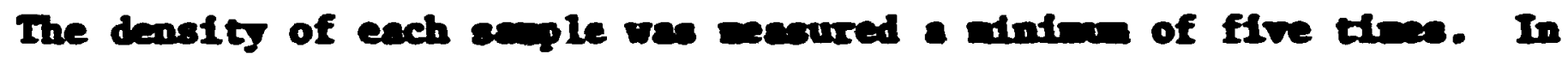

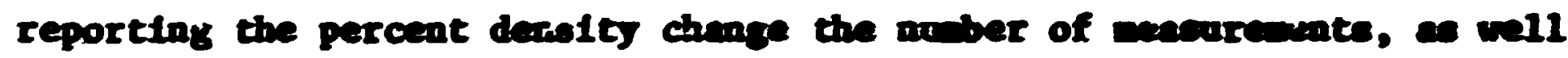
as the standard deviation of these masurvante is given. 


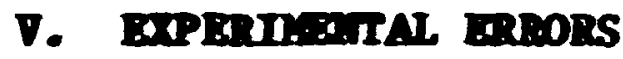

Poasible sources of errors associated with these experineats and peareresents are: (1) the temperature, (2) the accuracy of the fast pentron flures and fluences, (3) the errors associated with measurenent of defect densities and sizes by TH, and (4) errors encountered in nesourenent of the inmersion density. Throughout this investigatica attente were ande to afininise the errors by adopting standard technic nes of esourenent. In those cases in which the exror cannot be definitely established, such ar with the Irradiation temperature and the fast neutrox fluses and fluesces, the methods used in obtafning the reported valses are deccribed. In this way other investigators can adjust these rescits as future mensurenents of the reactor envirounent dictate.

In order to mintaize the errors in irradiation terperature ephasis was placed on spectwens which were resoved from posttions along the length of Ban-II conposents at wich the terperature was constant. At the botton of the reactor core and extending downard the temperature was in the range of $370-380^{\circ} \mathrm{r}$. This temperuture is accurately lonom because the inlet coolant tesperature is wonttored and controlled. In 1ike samer the temperature courard the top or slightly sbove the reactor core and exteading upurads also reasins cowsent. The exact position along the length of a conponent at which the temperature resches its

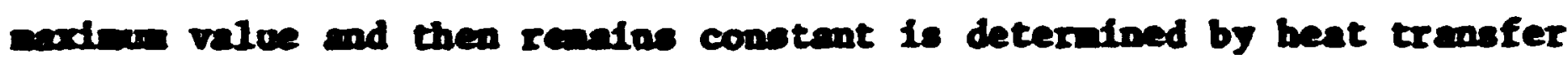
conditions. Calculated temperature profiles for the various components were supplied by Argonne Dational I-booratory (62). Brphasis was placed 
on specinens rexoved from positions at wich the calculated tesperatures were in the range of $460-470^{\circ} \mathrm{C}$. For specinens irradiated in experimental subasse-bly $x 0-34$ a range of irradiation temeratures is also specified (i.e., $570-630^{\circ} \mathrm{C}$ or $770-840^{\circ} \mathrm{C}$ ). The lower and upper tenperatures of this range are based on heating rates of 3.0 and 4.0 watts per gran (In iron) at the Row 2 reactor midplane at a reactor power level of $50 \mathrm{~m}$. This is belleved to be a conservative estinate of the possible range of heating rates and thus the irradiation temperatures.

The method used in obtaining the fast aeutron fluxes and fluences for the various components and experiments is described in Appendix A. This is probably the largest source of absolute error since there is approxinately a 202 difference between the ron 2 Adplane calculated flux and that neasured by dosimetry. Fluence values are based upon the experimentally deternioed value of the flur $\left[2.1 \times 10^{15}\right.$ neutrons $/ c^{2}$ sec (total)]. The flux distribution and everss spectron measurements and calculations of raphouse et a․ (68) are used consistent1y. Hagnification and deternination of the foll thickneas are the ajor errors assoctated with the quantative transiseion electron nicroscopy studies. The aagnification of a gived photoncrograph is entimted to be correct to within $\pm 5 \%$. Errors in eaguification vere minifiad by taking wost of the TBA photonicrographe which were subsequently used for quantitative evalustions at ceason aicroscope settings (leas current, etc.). Deternination of the foll thichness using sterondcroscopy is estinatid to be accurate to $\pm 20 \%$. The actual variation in void concentrations as ceterained in two different foils of the some irratlated spectures are presented in Appendix B. 
The fractional change in density as deternined by the imersion technique is calculated from Equation 34:

$$
\frac{\Delta \rho}{\rho_{0}}=\frac{\rho_{I}-\rho_{0}}{\underline{\rho_{0}}}
$$

The standard deviation associated with this fractional change in density can be shown to be:

$$
\sigma^{\sigma}\left(\frac{\Delta \rho}{\rho_{0}}\right)=\left\{\frac{\partial}{\partial \rho_{0}}\left(\frac{\Delta \rho}{\rho}\right) \sigma_{\rho_{0}}^{2}+\frac{\partial}{\partial \rho_{I}}\left(\frac{\Delta \rho}{\rho_{0}}\right) \sigma_{\rho_{I}}^{2}\right\}^{1 / 2}
$$

where

$$
\begin{aligned}
\sigma_{\left(\frac{\Delta \rho}{\rho_{0}}\right)}= & \text { standard deviation of density change, } \\
\sigma_{\rho_{0}}= & \text { standard deviation associated with measurement of } \\
& \text { unirradiated density, and } \\
\sigma_{\rho_{I}}= & \text { standard deviation associated with measurement of } \\
& \text { irradiated density. }
\end{aligned}
$$

If it is assumed that the standard deviation of the unirradiated specisens $\left(\sigma_{\rho_{0}}\right)$ Is equal to that of the Irradiated specimen $\left(\sigma_{\rho_{I}}\right)$ then Equation 35 becomes:

$$
\sigma\left(\frac{\Delta \rho}{\rho_{0}}\right)=\sigma_{\rho_{I}} \frac{\left(\rho_{0}-\rho_{I}\right)^{1 / 2}}{\rho_{0}}
$$

Standard deviations for the density change determined by Equation 36 are listed with the results of the density weasuremente. 
CHAPTER V

\section{RESILTS}

Radiation darage to type 304 stainless steel was studied through an examination of specimens which were removed from various BBR-II conponents and to specimens Irradiated in EBR-II experimental subassemblier Two main techniques used to characterize the damage were: (1) transmission electron microscopy (TEM), and (2) direct measurement of the irradiation produced density changes. The transmission electron afcroscopy observations are presented first, since they illustrate the nature of the damage. Since a large fraction of the specimens exanined cane from EBR-II components, emphasis was placed on characterizing the damage in considerable detail at irradiation temperatures of $370-380^{\circ} \mathrm{C}$ and $460-470^{\circ} \mathrm{C}$. These two temperatures were picked because they ware the most accurately known part of the temperature gradient along the components and because a wide range of fast neutron fluences could be obtained at these temperatures. The effect of irradiation temperature on the damage structure was investigated through a series of specinens irradiated to fluences of 3.75 to $4.0 \times 10^{22}$ neutrons $/ \mathrm{cm}^{2}(\mathrm{E}>0.1 \mathrm{MeV}$ ) at four temperatures in the range 370 to $840^{\circ} \mathrm{C}$. The possible importance of transmutation produced heliuin on the Irradiation damage process was examined in a specimen of type 304 staiuless steel containing $20 \times 10^{-6}$ atom fraction helium and Irradiated at $390^{\circ} \mathrm{C}$ to $7.6 \times 10^{21}$ neutrons $/ \mathrm{cm}^{2}$ (E > $0.1 \mathrm{MeV})$. The damage structure in this specimen was coupared to 
that in a control specinen which contained no heliw prior to an Identical irradiation.

\section{TRALSAISSIOA BLECTROA MICROSCOPY OBSERVATIOAS}

\section{Daage at Low Neutron Fluence}

In type 304 stainless steel Irradiated to $1.1 \times 10^{18}$ neutrons $/ \mathrm{cm}^{2}$ (B >0.1 MeV) at $370^{\circ} \mathrm{C}$ no danage was observed when the specinens vere exanined in the electron microscope under either diffraction or absorption contrast conditions. After irradiation at $384^{\circ} \mathrm{C}$ to $1.4 \times 10^{20}$ neutrons/ca?" (E > $0.1 \mathrm{KeV}$ ) small defect clusters such as those shown in Figure 17 were observed. These clusters were visible only when the foil was oriented near a diffraction position thus indicating that the spots were defects having a small strain field associated with then. With the exception of a swall denided zone near grain boundaries, which can also be seen in Fignie 17, the defect clusters appeared to be homogeneously dist-ibuted throughout the grains. As the 1rradiation temerature was increased and the neutron fluence held constant at $1.4 \times 10^{20}$ neutrons/ $\mathrm{cm}^{2}$ ( $\mathrm{E}>0.1 \mathrm{MeV}$ ) the concentration of defect clusters dropped sharply, Figure 18. Approximately $1.5 \times 10^{13}$ clustere/cm were present in a spectmen which was 1 radiated at $496^{\circ} \mathrm{C}$ and no defects were observed (Irdicating that the defect concentration was less than approximately $10^{12}$ defects $/ \mathrm{cm}^{3}$ ) in a specimen irradiated at $524^{\circ} \mathrm{C}$. For this value of fluence the temperature cutoff for visible damage 18 between 496 and $524^{\circ} \mathrm{C}$. When the specimens were examined under absorption conditions no demage was observed. 


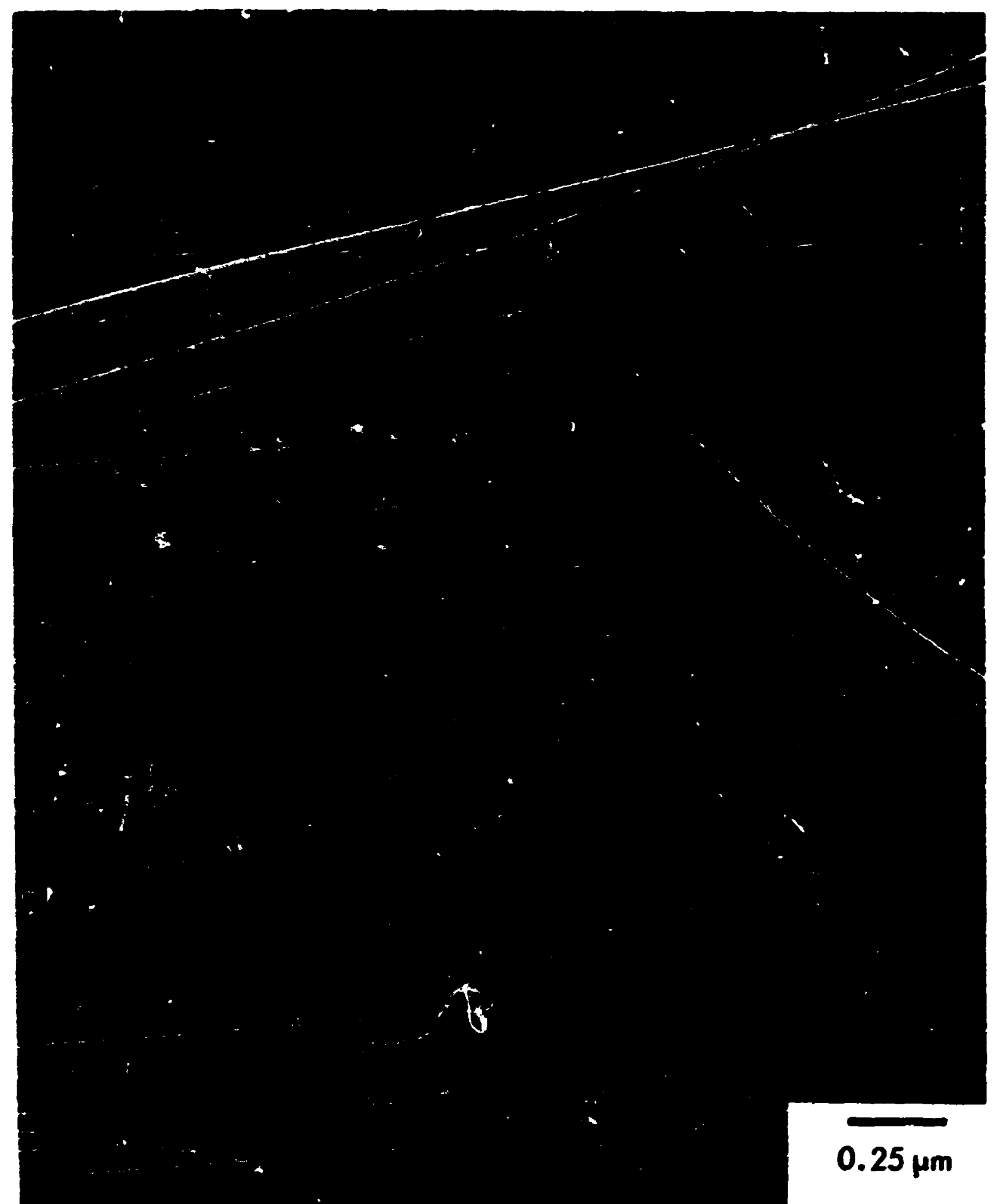

Figure 17. Transmission electron micrograph showing refect clusters in type 304 stainless steel irradiated at $384^{\circ} \mathrm{C}$ to $1.4 \times 10^{20}$ neutrons $/ \mathrm{cm}^{2}(\mathrm{E}>0.1 \mathrm{MeV})$. 


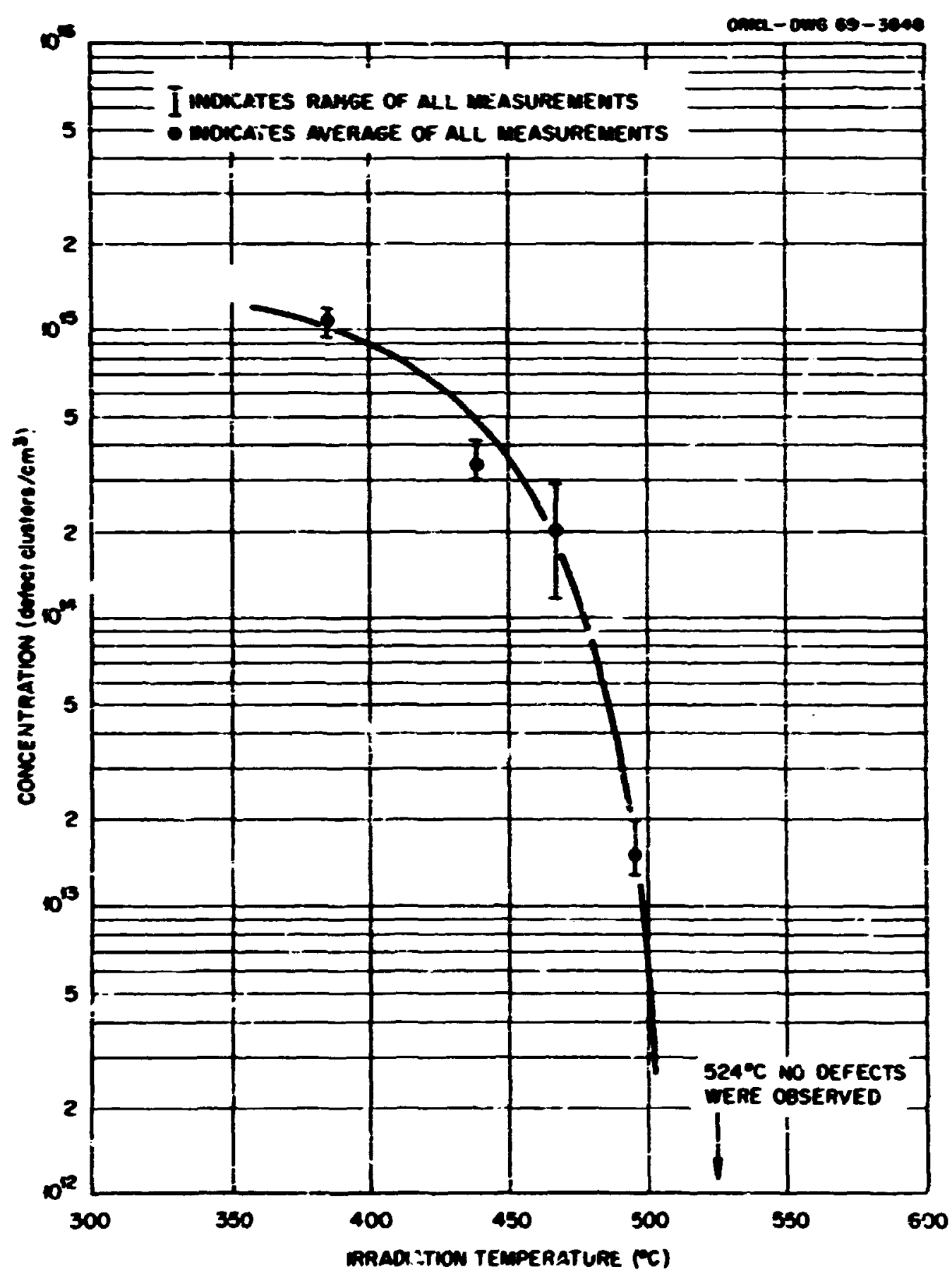

Figure 18. Concentration of defect clusters in type 304 stainless sceel jrradiated at temperatures between 384 and $524^{\circ} \mathrm{C}$ to $1.4 \times 10^{20}$ neutrons $/ \mathrm{mm}^{2}(\mathrm{~B}>0.1 \mathrm{MeV})$. 
The nature of the defect clusters was studied in a specimen Irradiated at $467^{\circ} \mathrm{C}$. Sanall defect clusters such as those shown in Figure 17 exhibit black-ihite contrast under dynanical two besm conditfons. As outlined by Rîhle (69), the direction $\boldsymbol{I}$ of the black-to-shite contrast depends on the type of defect caislog the contrast and also on the diffraction vector wich is operating. If the defect is planar, e.g., a dislocation 100p, then the direction of $\bar{l}$ is the projection, in a plane perpendicular to the bean, of the Burgers' vector of the 10op. In this case, $\bar{l}$ is an intrinsic property of the loop and is not dependent on the diffraction vector $\overline{8}$. If on the other hand, the defect has a spherically symetric strain field the direction of $\bar{l}$ is dependent on $\overline{8}$ and is in the direction of $\overline{8}$. By observing the direction of $\bar{l}$ when varicus $\overline{8}$ vectors were operative, it was possible to identify three defect types:

1. A defect exhibiting contrast consistent with that expected fron a dislocation loop with an $\frac{a}{3}\langle 1\rangle$ Burgers" vector.

2. A defect exhibiting contrast consistent with that expected from a dislocation loop with an $\frac{a}{2}\langle 110\rangle$ Burgers' vector.

3. A defect exhibiting contrast consistent with thet expected from a spherically symetric stratn fleld.

Figure 19 shows defects observed under two bean conditions such that the blakk-white contrast is visible. In this particular ares of the foll, defects exhibiting contrast as expected from $\frac{a}{3}\langle 11\rangle$ disle iation loops are visible. Of the approxdately 50 defects analyzed in this uanner, wre than $75 \%$ exhibited contrast expected from $\frac{a}{3}$ (11) dislocation 

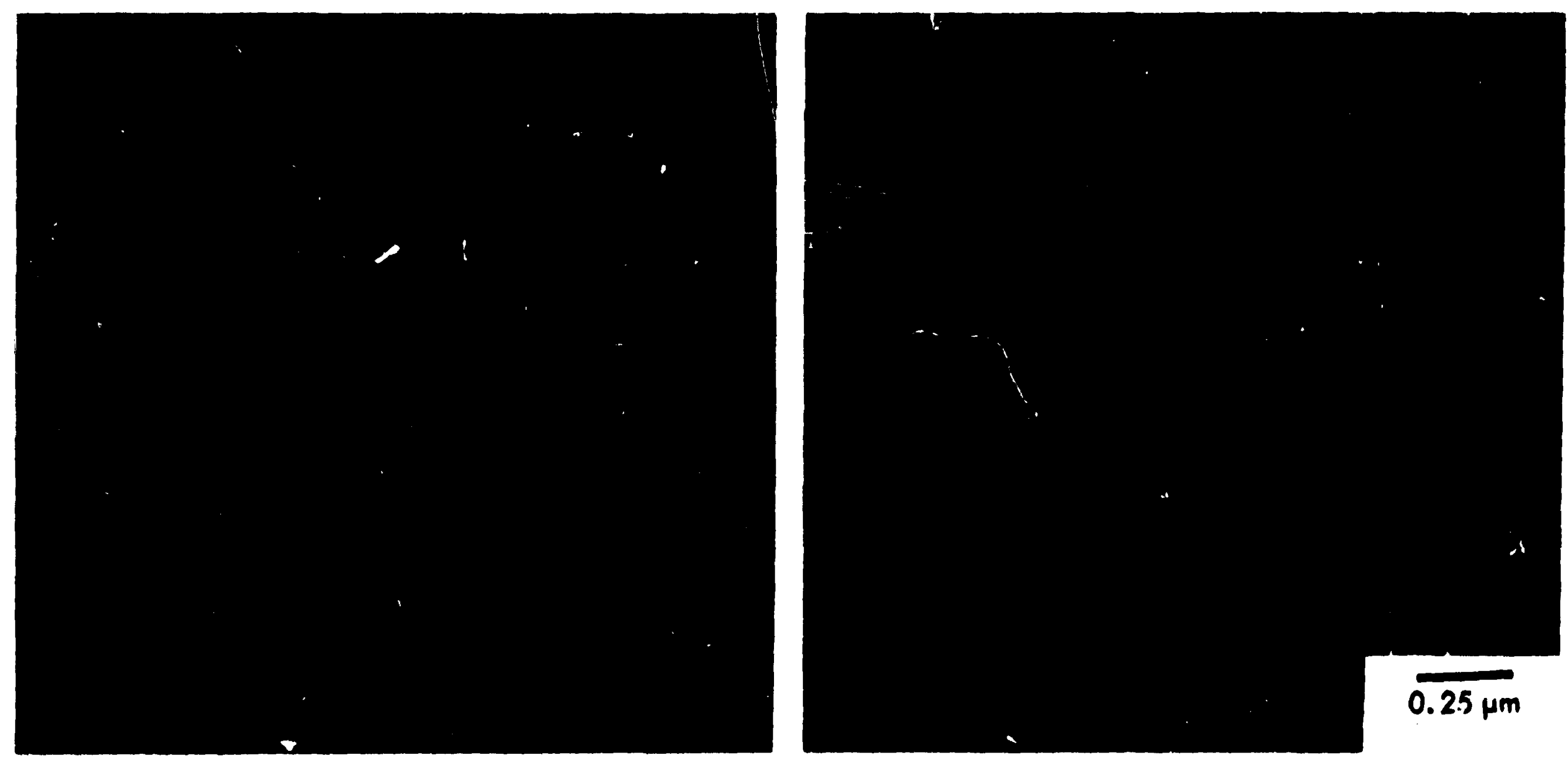

Figure 19. Sma11 dot-like defects observed under two beam diffraction conditions.

The direction of the black-to-white contrast remalns the same for different $\overline{8}$ vectors; thus, labeled defects are dislocation 100ps. 
loops. Stiegler $(70)$ has detemined that the $\frac{a}{3}\langle 111\rangle$ defects exhibit contrast behavior consistent with that expected fron interstitial dislocation loops.

At higher fast neutron fluences the damage was wore and wore complicated. For fluences up to approximately $1 \times 10^{21}$ neutrons $/ \mathrm{cm}^{2}$ (E $>0.1 \mathrm{HeV}$, the visible damage continued to be dislocation loops. However, when specimens which had been irradiated to fluences in excess of approximately $1 \times 10^{21}$ neutrons $/ \mathrm{cm}^{2}(E>0.1 \mathrm{Ms}$; were exanined under absorption contrast conditions, cavities ranging up to a few hundred A dianeter were observed. Exanination of stereo ncrographs showe!! the cavities to be contained within the foll and not in contact with the foil surface, thus, indicating that they were not polishing artifacts. Previous investigations $(1,2,52,53,54,55)$ have ade sinilar observations and nave also conrluded that these cavities are irrajiation produced voids.

Because the loop structure is visible under diffraction conditions and the volds are visible under absorption conditions these two defects will be discussed separately from this point forward.

Dislocation Loops and Networks

The dislocation loop structure produced by different fast neutron fluence at constant irradiation temperatures of $370-380^{\circ} \mathrm{C}$ are 11lustrated in Figures 20 and 21. After irradiation to $2.0 \times 10^{21}$ neutrons/cis (E $>0.1 \mathrm{MeV}$ ) at $370^{\circ} \mathrm{C}$ (Figuie 20), the dislocation loops were larger than after irradiation to $1.4 \times 10^{20}$ neutrons $/ \mathrm{cm}^{2}$ (B $>0.1 \mathrm{MeV}$ ) at 


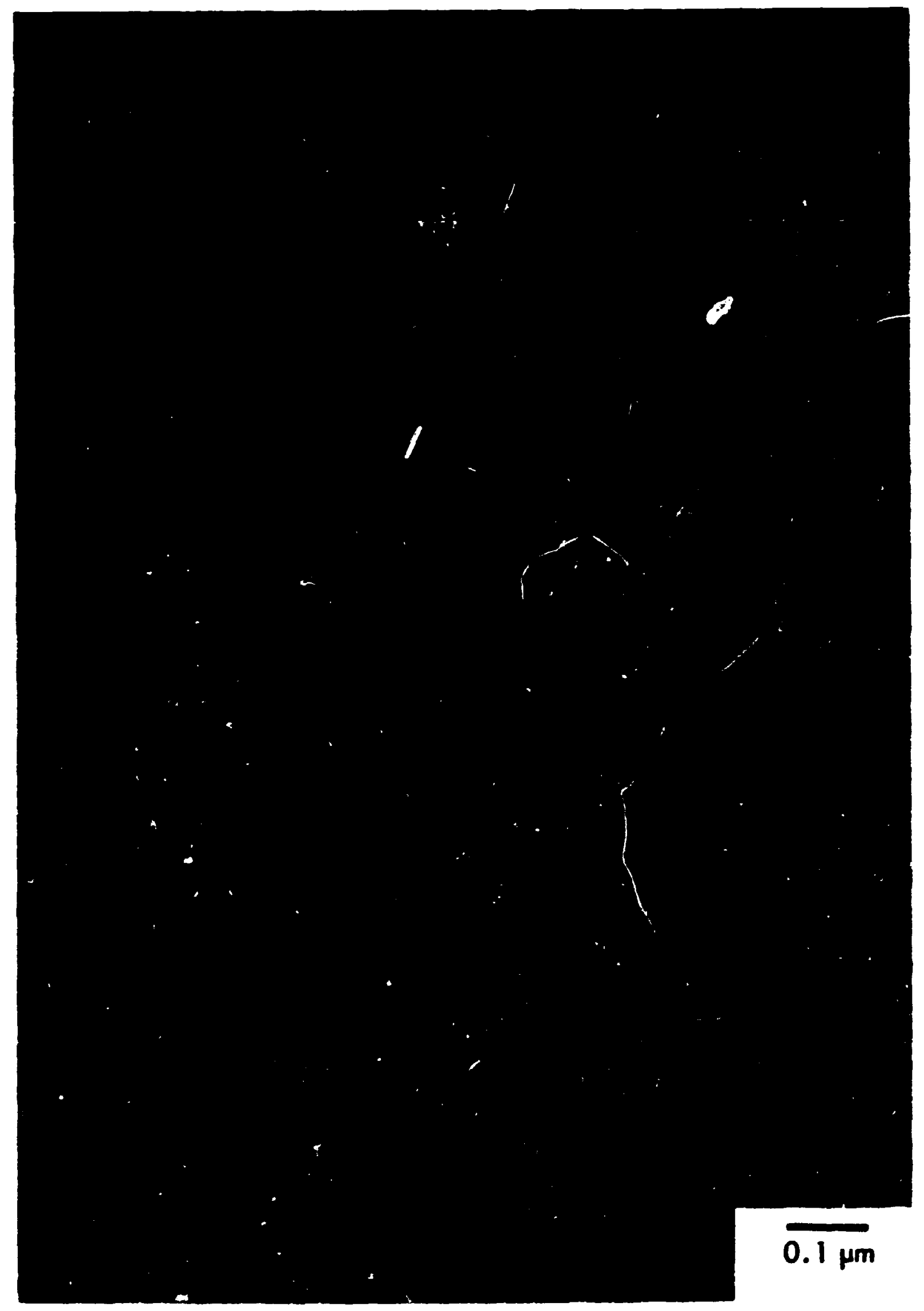

Figure 20. Dislocation 1cops in type 304 stainless steel irradiated at $370^{\circ} \mathrm{C}$ to $2.0 \times 10^{21}$ neutrons $/ \mathrm{cm}^{2}$ ( $\left.\mathrm{E}>0.1 \mathrm{MeV}\right)$.

Note the clustering of the loops. 

approximately the same temperature (Figure 17, page 65). Tiere was evidence that in tue specinen irradiated to $2.0 \times 10^{21}$ neutrons $/ \mathrm{cm}^{2}$ (E $>0.1 \mathrm{MeV}$ ) the loop structure was not homogeñesusly distributed. The concentration of loops in the imediate vicinity of grown-in dislocations was much higher than in the surrounding matrix. The only apparent iifference between these two specimens is that the specimen irradiated to $1.4 \times 10^{20}$ neutrons/ $\mathrm{cm}^{2}$ (E > $0.1 \mathrm{MeV}$ ) had a lower preirradiation dislocation density than the specimen irradiated to the higher fluence.

With increasing fast neutron fluence the dislocation loop structure becomes progressively mre criplex. Figure 21 shows specimens irradiated at $370-380^{\circ} \mathrm{C}$ to $5 \times 10^{21}$ and $5 \times 10^{22}$ neutrons $/ \mathrm{cm}^{2}(\mathrm{E}>0.1$ MeV). Even at the lower of these two fluences the loop concentration is too large to be accurately measured. In the lower fluence specimen fringes can be seen in those loops having the correct orientation with respect to the plane of the foll. These fringes indicate the presence of a stacking fault. Because of the high Loop concentration, inhonogeneities in the loop distributions are not apparent if they are present. In the specimen irradiated to $5 \times 10^{22}$ neutrons $/ \mathrm{cm}^{2}(\mathrm{E}>0.1 \mathrm{MeV}$ ) the loop concentration is so high that it is impossible to resolve individual 1oops.

After irradiation at $460-470^{\circ} \mathrm{C}$ to a neutron fluence of $1.4 \times 10^{20}$ neutrons $/ \mathrm{cm}^{2}\left(\mathrm{~B}_{0}>0.1 \mathrm{MeV}\right)$ a structure shown in Pigure 22 was found. The specimen contained approximately $2 \times 10^{14}$ defect clusters $/ \mathrm{cm}^{3}$.

Figure 23 shows a specimen which was irradiated to $5 \times 10^{20}$ neutrons $/ \mathrm{cm}^{2}$. This spectmen did not contain defect clusters. However, 


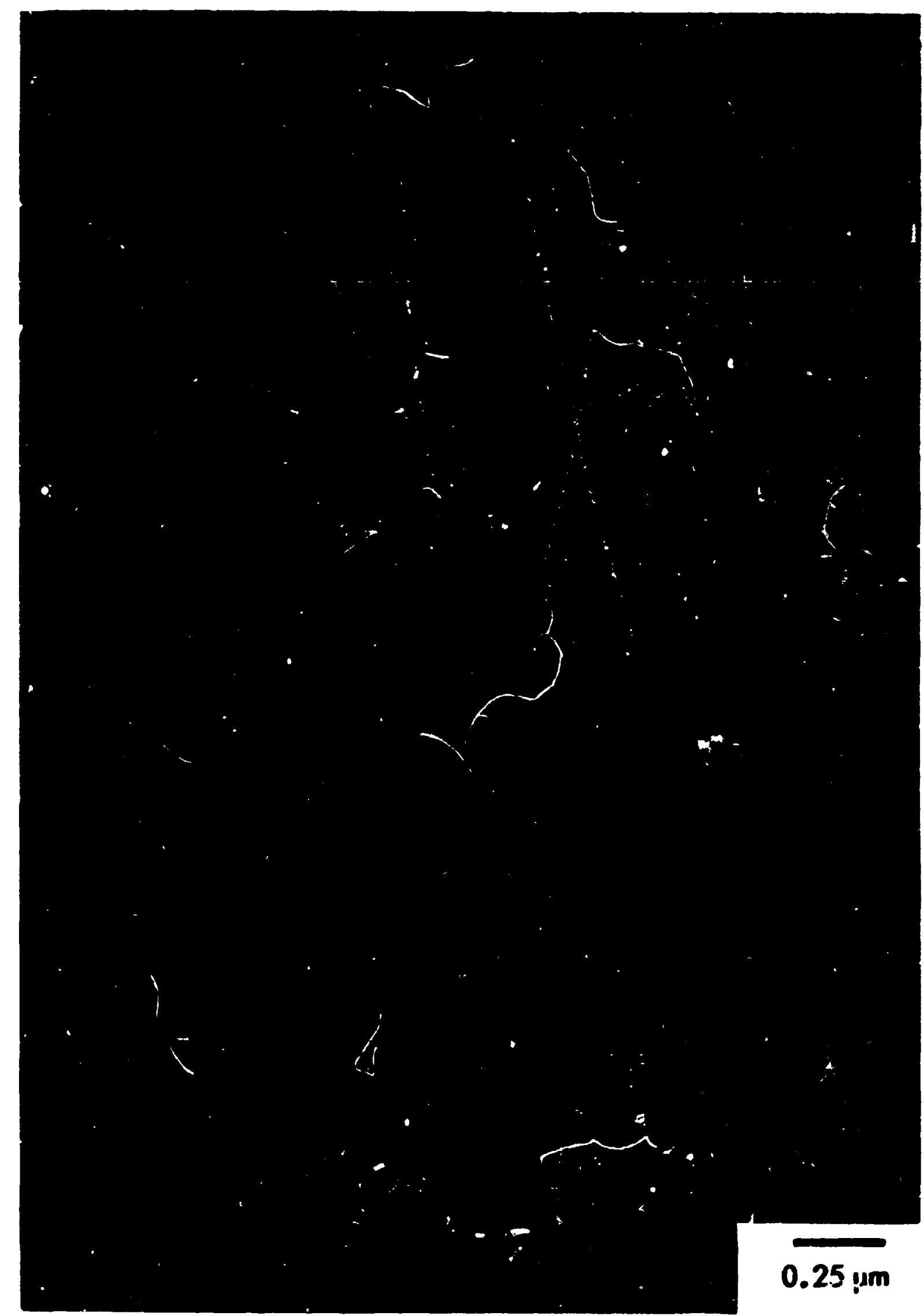

Figure 22. Defect clusters in type 304 stainless steel irradiated at $460-470^{\circ} \mathrm{C}$ to $1.4 \times 10^{20}$ neutrons $/ \mathrm{cm}^{2}$. ( $\mathrm{E}>0.1 \mathrm{MeV}$ ) at a neutron flux of $1.9 \times 10^{15}$ neutrons $/ \mathrm{cm}^{2} / \mathrm{sec}(\mathrm{E}>0.1 \mathrm{MeV})$. 


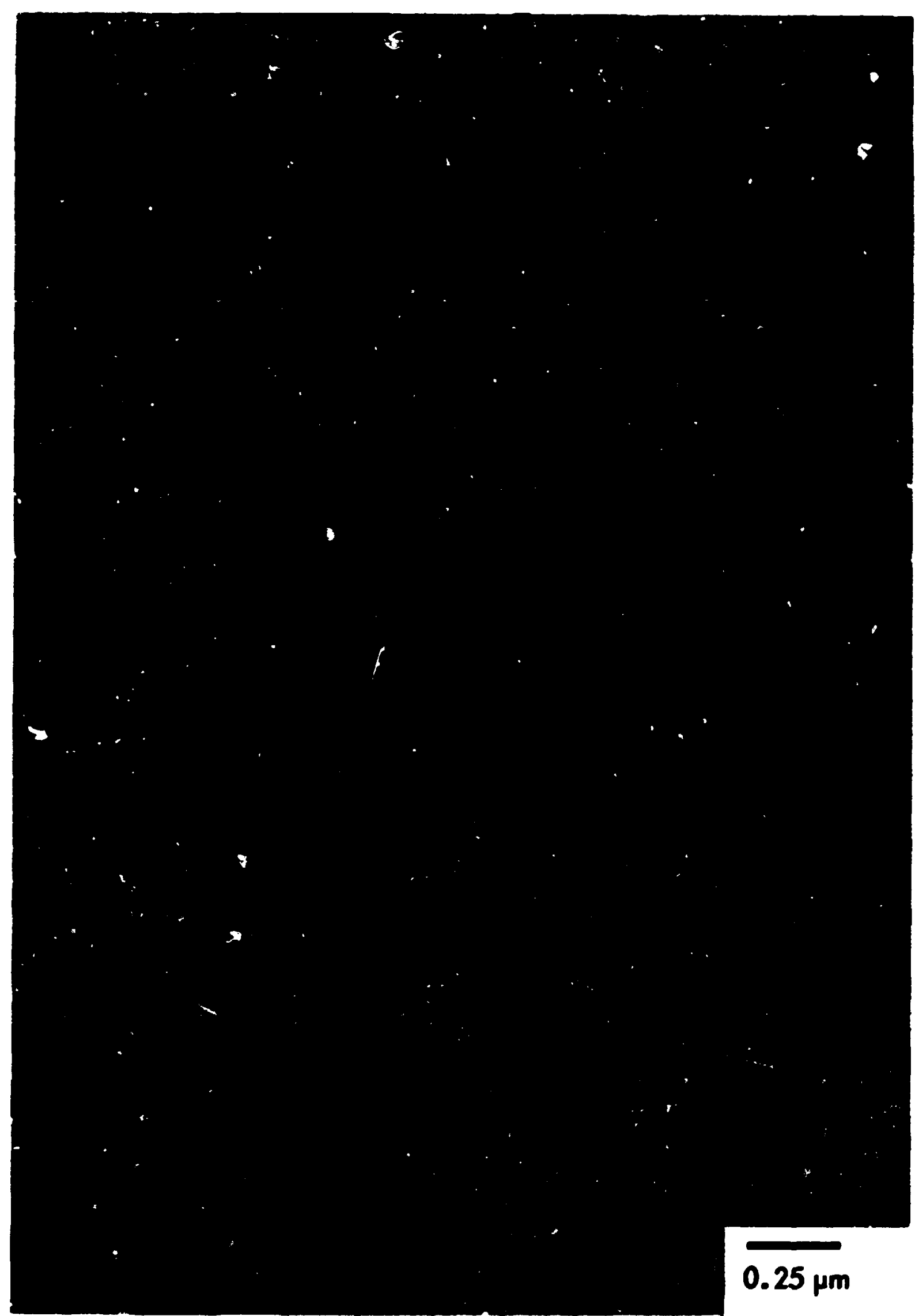

P1gure 23. Dislocation 11ne - precipitate structure in specimen Irradiated at $460-470^{\circ} \mathrm{C}$ to $5 \times 10^{20}$ neutrons $/ \mathrm{cm}^{2}$ ( $\mathrm{B}>0.1 \mathrm{MeV}$ ) at a neutron flux of approximately $4 \times 10^{13}$ neutrons $/ \mathrm{cm}^{2} / \mathrm{sec}$ ( $B>0.1 \mathrm{MeV}$ ). 
the grown in dislocations were decorated with what stereo nicroscopy suggested were small rod-shaped precipitates.

The different microstructures present in these two specimens apparently resulted from different irradiation conditions; $1 . e .$, the fast neutron flux and the irradiation time. The specimen containing the defect clusters was irradiated in a flux of $1.9 \times 10^{15}$ neutrons/ca ${ }^{2} /$ sec for $20.5 \mathrm{hr}$, whereas the specimen containing the dislocationprecipitate structure was irradiated in a flux of $1.7 \times 10^{13}$ neutrons/ $\mathrm{cm}^{2} / \mathrm{sec}$ for $8200 \mathrm{hr}$. Thus, the specimen irradiated to $1.4 \times 10^{20}$ neutrons/ca" at a "high" fast neutron flux contained defect clusters which were apparently vacancy and interstitial in nature while the speciren irradiated to $5 \times 10^{20}$ neutrons/ $\mathrm{cm}^{2}$ at a fast neutron flux which was about a factor of 100 lower did not contain such clusters.

The dislocation line - precipitate structure shown in Figure 23 is almost identical in appearance to precipitate structures observed by Singhal and Martin (71) and Beckitt and Clark (72). In these Investigations the structures were identified as $\mathrm{M}_{23} \mathrm{C}_{6}$ carbides precipitated on dislocations in unirradiated austenitic stainless steels as a result of therwal aging at temperatures of 560 and $700^{\circ} \mathrm{C}$ for short times, near $1 \mathrm{hr}$. Brager and Rissinger (73) have shown that $\mathrm{M}_{23} \mathrm{C}_{6}$ carbides are formed in type 316 stainless during irradiation at $480^{\circ} \mathrm{C}$, whereas in control spectmens aged at the irradiation temperature for the irradiation time no precipitation occurred. In the present investigation, it appears that the dislocation precipitate structure resulted from the precipitation of carbides, probably of the $\mathrm{H}_{23} \mathrm{C}_{6}$ type on dislocations 
which were present prior to irradiation.

Comparison of the appearance of the dislocation loop strusture at different fluences for a constant Irradiation tenperatire of $460-470^{\circ} \mathrm{C}$ is further 11lustrated in Figures 24 and 25. After Irradiation to $2 \times 10^{21}$ neutrons/ $\mathrm{an}^{2}(\mathrm{~B}>0.1 \mathrm{HeV})$ the concentration of the dislocation line - precipitate structure (labeled A in Figure 24) had not changed appreciably although the precipitates vere larger, extending 500 to 1000 a into the surrounding matrix. The specimens shown in Figures 23 and 24 were both taken fron the EBR-II shroud tube and were subjected to sinilar thernal histories, i.e., $8200 \mathrm{hr}$ at $460^{\circ} \mathrm{C}$. The larger precipitates in the higher fluence specinen nay be a result of the irradiation conditions: 1.e., the higher fast neutron flux and/or fluence. In addition, defects exhibiting the characteristics of dislocation ioops were also observed at this slightly higher fluence. Host of these loops were very Irregular in shape (labeled B in Figure 24) although sone of the smaller loops were wre circular (labeled C in Figure 24). Stacking fault fringes were readily visible in the iarger $100 p$.

After the higher fluences, the dislocation line - precipitate structure and the rregularly shaped dislocation loops become more difficult to observe, possibly berause the other forms of danage obscure them. The irregularly shaped loops still appear to be present in F1gure 25. At fluences of approxdmately $1 \times 10^{22}$ nettrons/cm ${ }^{2}$ (E > $0.1 \mathrm{MeV}$ ) and higher, It was very diffcult to determine the nature of the loop structure because of the high loop densities and large loop 81zes. 


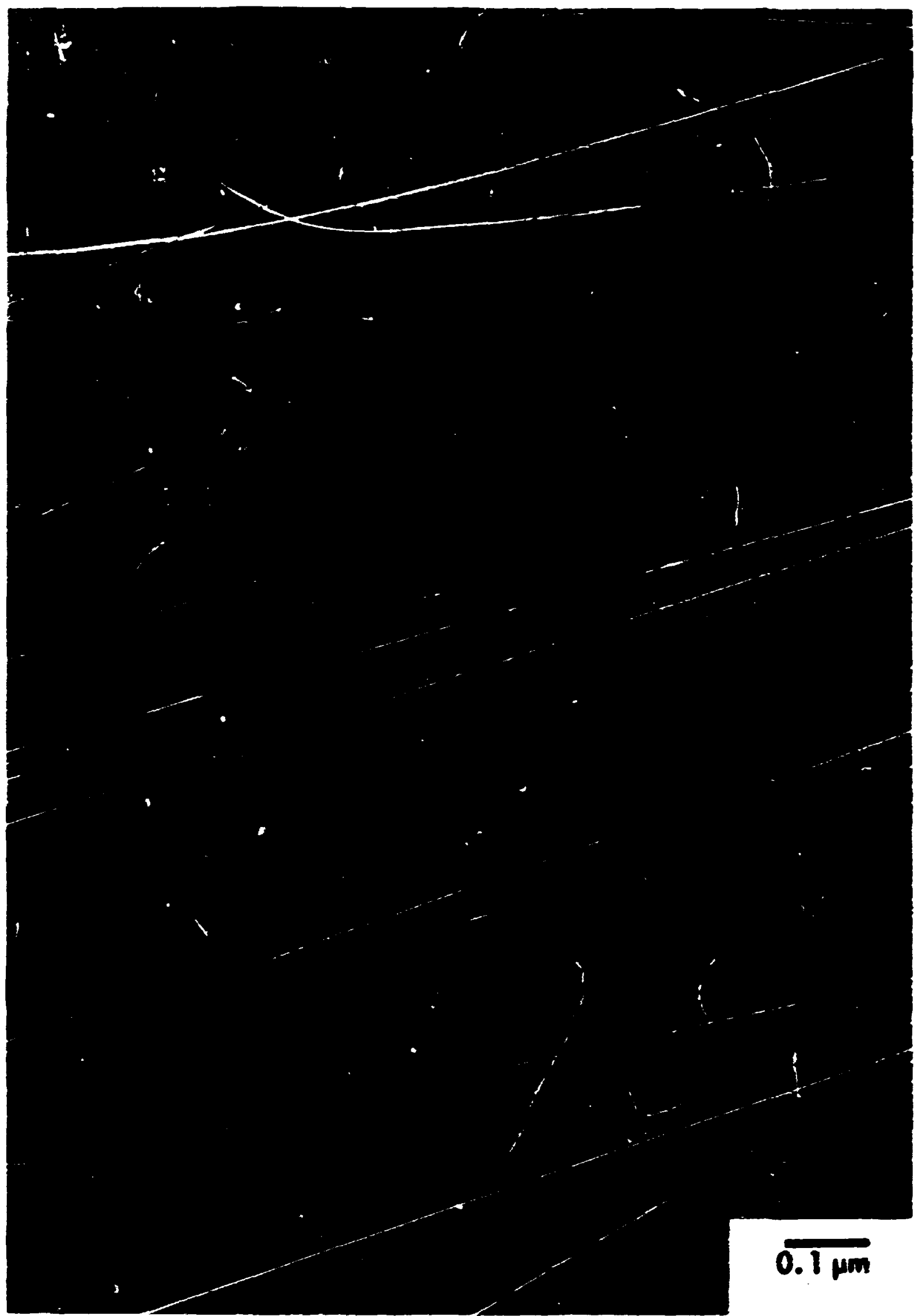

Figure 24. Exaplas of the loop and dislocation structures ioserved after irradiation to $2 \times 10^{21}$ neutrons/ $\mathrm{cm}^{2}(\mathrm{~B}>0.1 \mathrm{HeV}$ ) at $460-470^{\circ} \mathrm{C}$.

A. Dislocsicion line-precipitate structure. B. Ircegular shaped defect exhibiting contrast simliar to faulted disiocation $100 p$. C. Regular raulted dislocation 100p. 


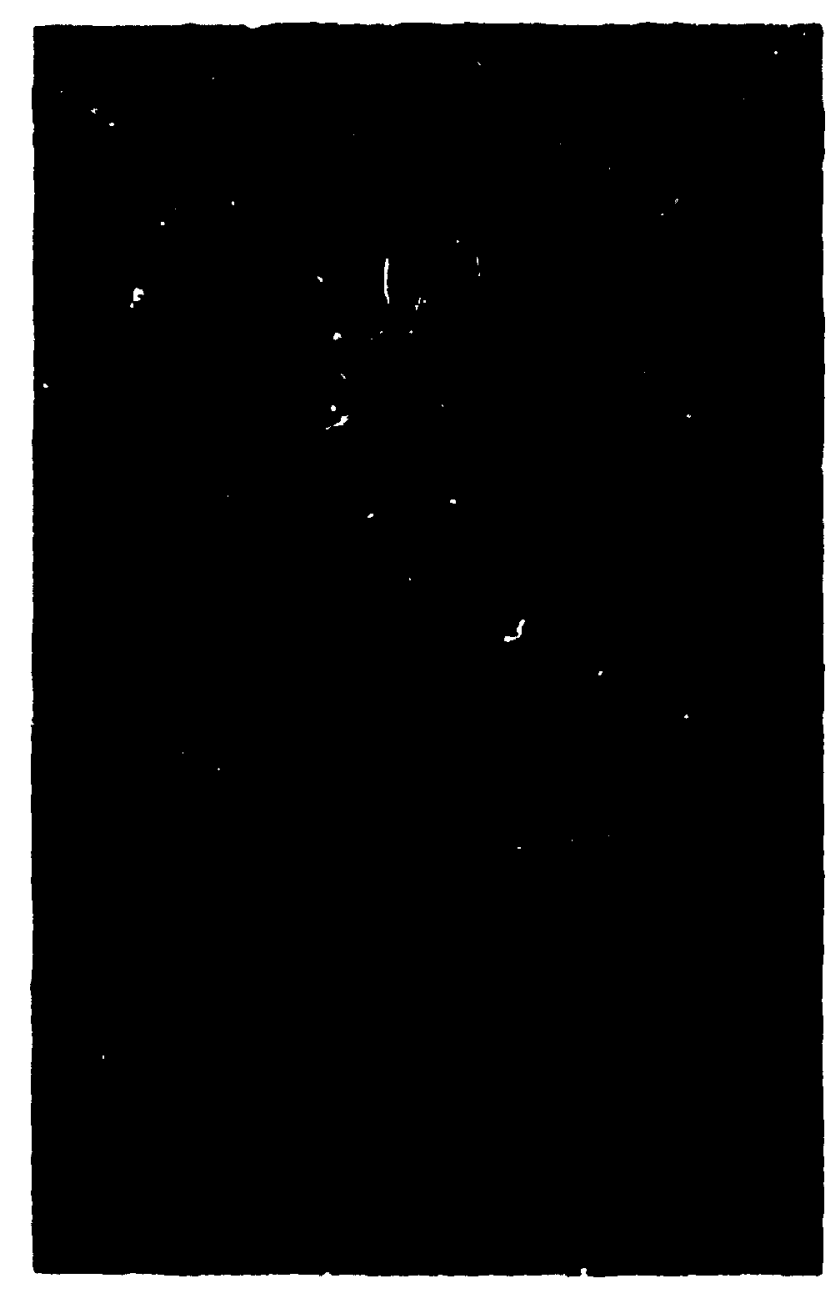

(a) $3.3 \times 10^{21}$ neutrens $/ \mathrm{cm}^{2}$ $(E>0.1 \mathrm{MeV})$

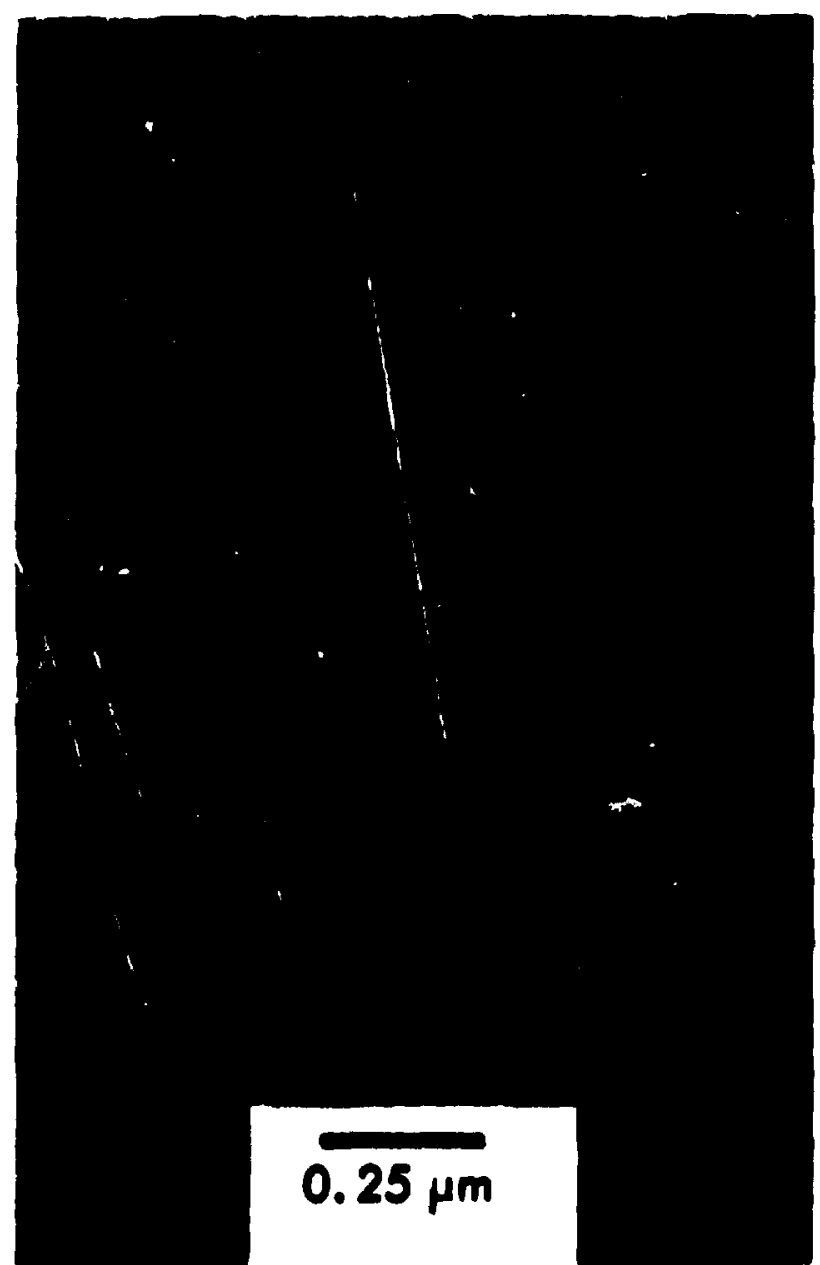

(b) $8.8 \times 10^{21}$ neutrons $/ \mathrm{cm}^{2}$ $(E>0.1 \mathrm{MeV})$

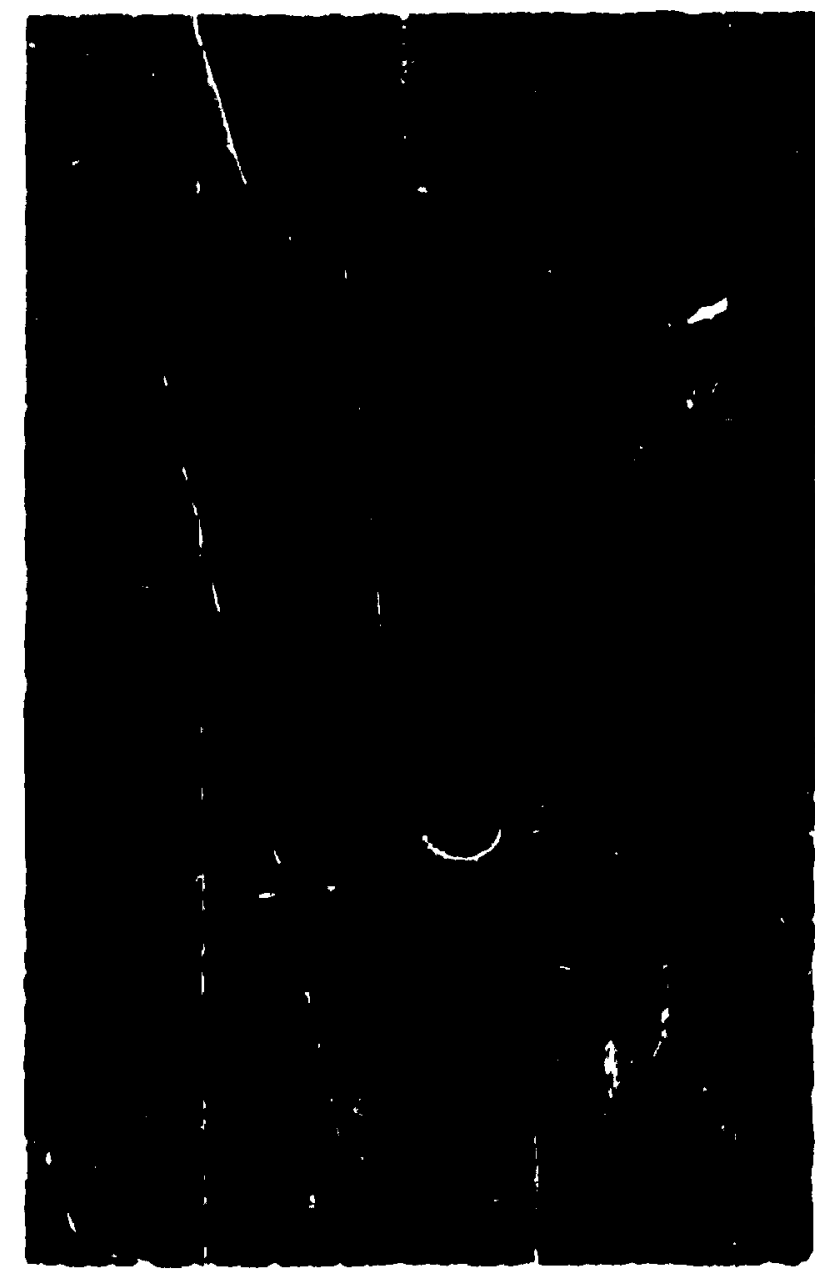

(c) $2.1 \times 10^{22}$ neutrons $/ \mathrm{cm}^{2}$ ( $\mathrm{E}>0.1 \mathrm{MeV})$

Figure 25. Effect of fast neutron fluence on the loop atructure in type 304 stalnlese steel irradiated at $460-470^{\circ} \mathrm{C}$. 
The nature of the dislocation loops, whether they were forned by the precipitation of vacancies or interstitials, was deternined in a specimen wist sh had been irradiated at $460^{\circ} \mathrm{C}$ to $2.8 \times 10^{21}$ neutrons $/ \mathrm{c}^{2}$ $(E>0.1 \mathrm{MV})$. The technique was suggested by Stiegler (70) and was a modification of the wethod usea by Mazey et al. (74) and Edmondson and Williansos (75). The technique is based on geonetrical argunents describing the contrast around a dislocation. Figure 26 is a schamatic representation of the distortion present in the vicinity of ac edge dislocation. Let $\theta$ be the angle between the incident beas $\left(I_{0}\right)$ and an undistorted lattice plane. If $\theta>\theta_{B}$ where $\theta_{B}$ is the Brags angie, and $\bar{s}>0$ (where $\bar{s}$ is the vector which brings the reciprocal lattice point into coincidence with the reflecting sphere) a clockurise rotation of the lattice at " $A$ " reduces the angle of incidence to $\theta_{B}$ and diffraction will occur in the vicintty of "A." Thus, In Figure 26 the inage of the dislocation appears to the right of the actual dislocation position. Note that at "B" the rotation of the lattics causes $\theta$ to deriace from, rather than approach, $\theta_{B} \cdot$ Conversely, if $\theta>\theta_{B}$ and the sign of $\overline{8}$ is reversed, the image of the dislocation appears on the right side of the dfolocation. When the dislocation is of opposite sign the rotations are oppcsite and for the same $\overline{8}, \bar{b}$, and $\overline{8}$ the dislocation inage will appear on the opposite side of the dislocation to that just described.

The case of an interstitial dislocation loop inclined to the plane of the foll is illustrated in Figure 27. In this case $\theta>\theta_{B}$, and the clockrise rotation of the lattice planes at points $A$ and $B$ brings the lattice at these points into a diffracting position, and 


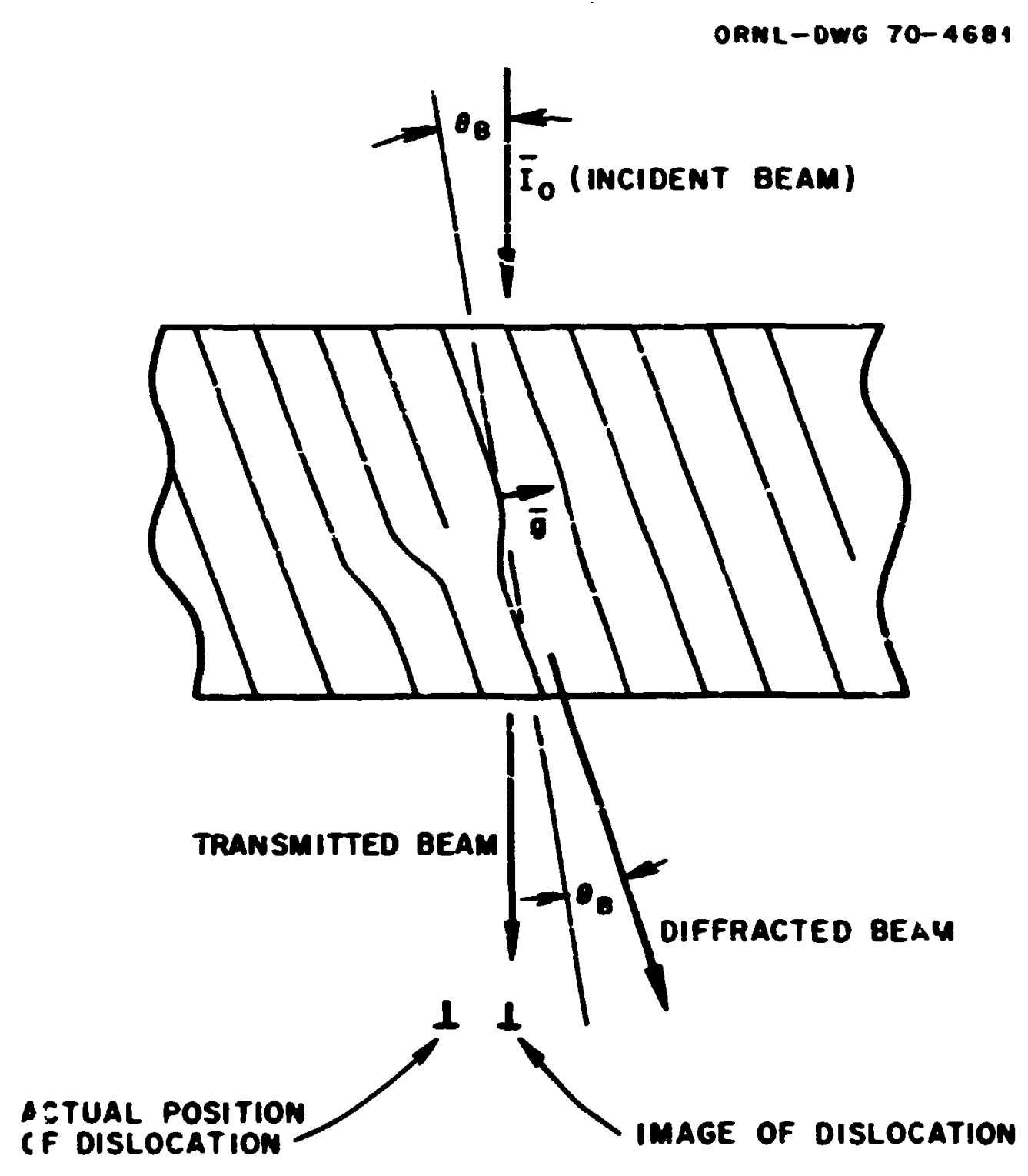

Figure 26. Geometric representation of the origin of diffraction contrast from an edge dislocation. 


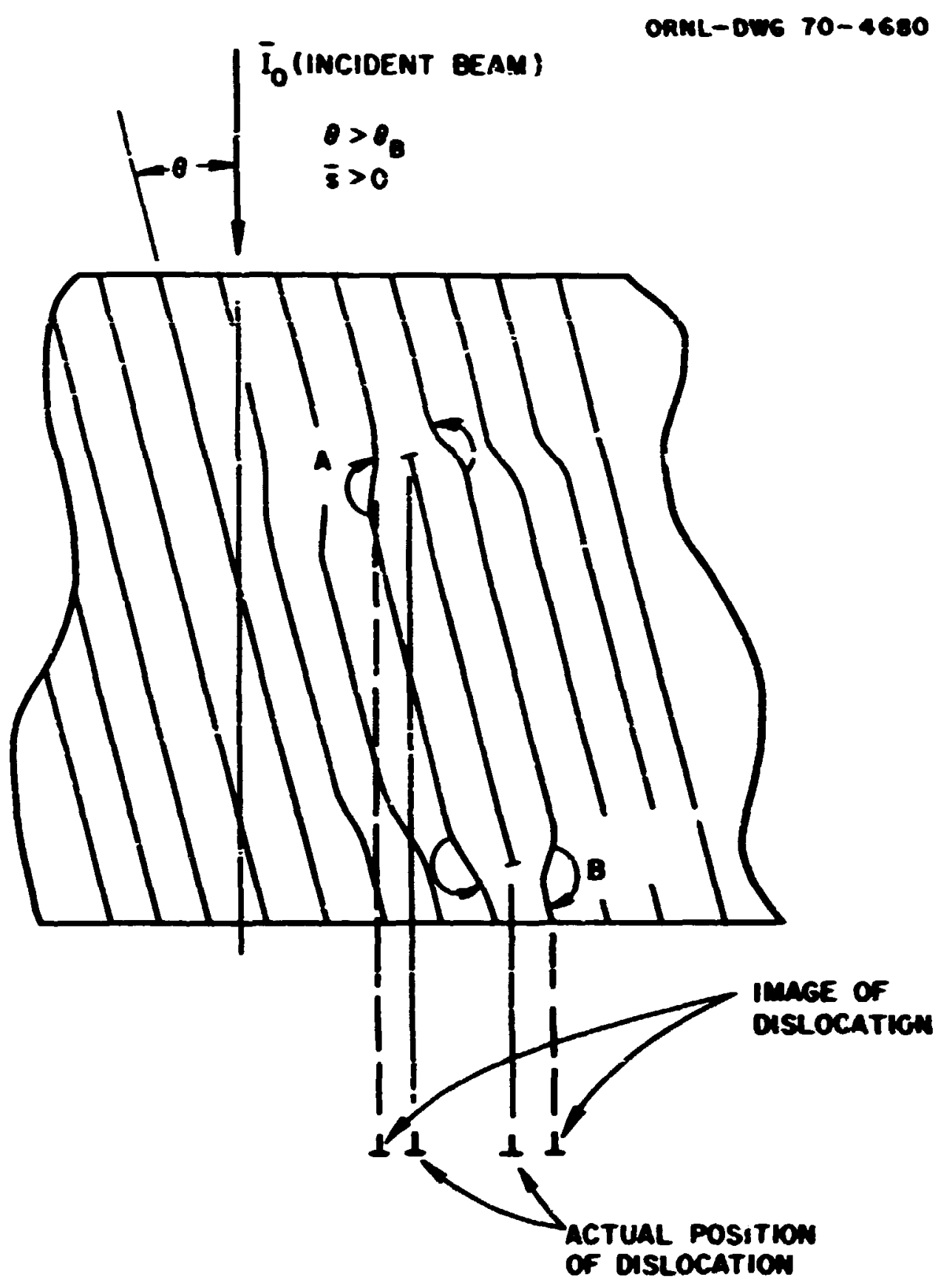

Figure 27. Geonetric representation of the linge produced by an interstitial dislocation loop.

The angle $\theta$ of the incident besm relative to the set of latticu planes being considered is greater than $E_{B}$, the Brags Angle. The cinckwre rotations of the lattice at $A$ and $B$ reduce $\theta$ to give an inage. For this condition the image if outside the sctual dislocation. 
produces a dislocation inage. For these conuitions the image is on the outside of the dislocation loop. If the loop were a vacancy $100 p(\overline{8}$ and $\bar{s}$ unchanged) the image would be on the inside of the dislocation. If in Figure 27 the sign of $\bar{g}$ were reversed the image would appear on the inside of the dislocation.

In order to deternine whether a dislocation loop is a vacancy loop or an interstitial loop it is necessary to know the inclination of the loop with respect to the surface of the foil, the direction of $\bar{b}$ (which for a loop having a stacking fault in an fcc lattice is a (111) direction), the diffraction conditions, $\bar{g}$, and the sign of $\bar{s}$ (i.e., $\theta$ $\left.>\theta_{B}, \bar{s}>0 ; \theta>\theta_{B}, \bar{s}>0\right)$. Since the position of the dislocation Image depends on $\bar{g}, \bar{b}$, and $\bar{s}$, if we keep $\bar{b}$ and $\bar{s}$ constant and change the sign of $\bar{g}$ the position of the inge will change from the inside to the outside of the actual location.

Figure 28 shows dislocation loops in a speciven irradiated at $460-470^{\circ} \mathrm{C}$ to $2.8 \times 10^{21}$ neutrons $/ \mathrm{cm}^{2}$ (E $>0.1 \mathrm{MeV}$ ) with both plus and minus $\overline{8}$ vectors operating ( $\overline{8}$ is positive in both cases). The loops wich exhibit stacing fault fringes in Figure 28a appear larger in Figure 280 indicating that when $\bar{g}$ was changed from plus to winus the dislocation iage shifted from inside to outside of the dislocation. Steronicroscopy was used to deternine the inclination of the loops to the surface of the foil. The behavior was that expected from interstitial dislocation 10ops. Note that in Figure 28, the defect labled A 18 an unfauited dislocation loop. A sall fraction of the total 


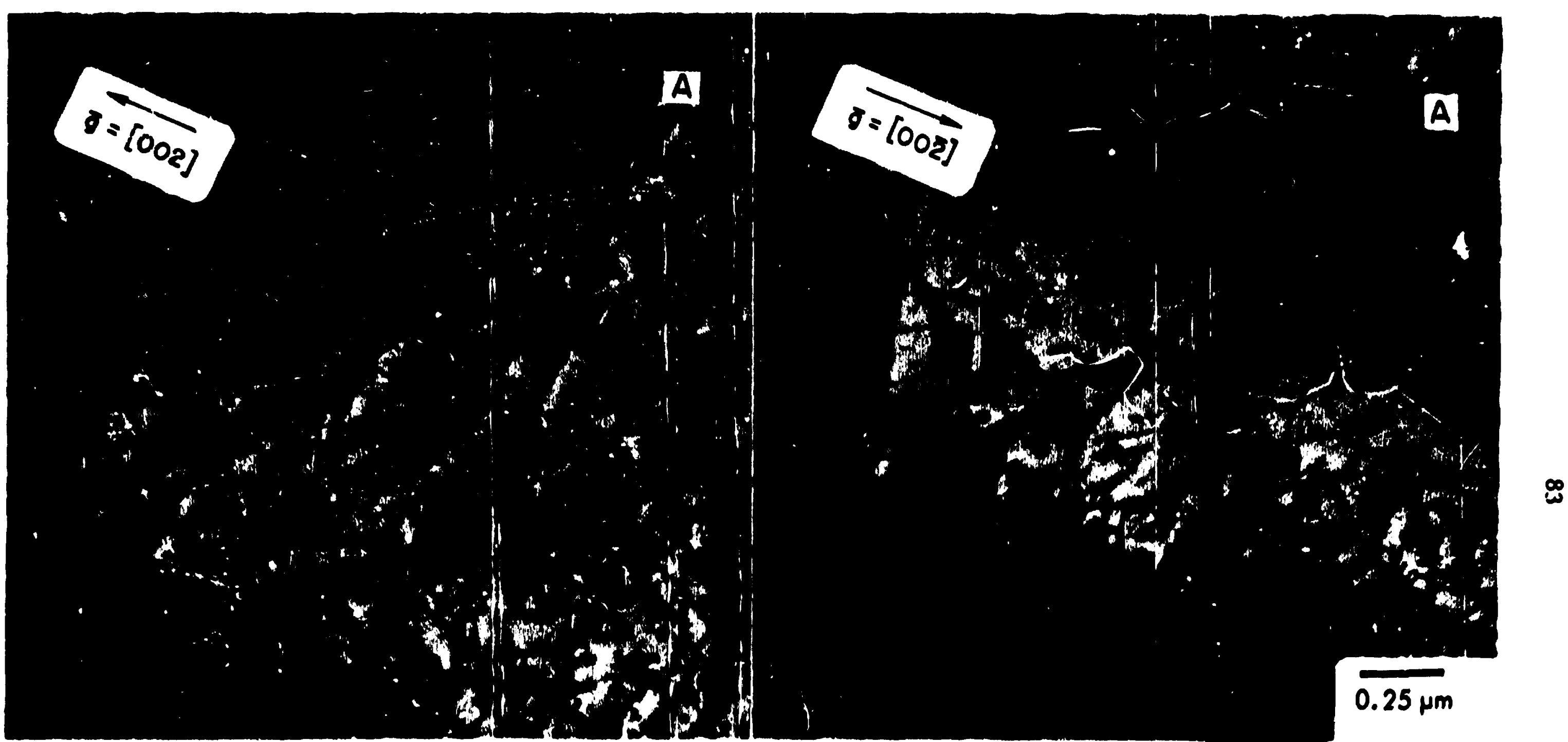

Figure 28. Dialoration loope w1th 002 and $00 \overline{2}$ diffraction vectorw operating.

Note that the loops which exhlb1t otacking fault fringes when the diffraction vector 10 002 become larger and no longer exhiblt these fringee when the diffraction vector 1o changed to 002 . Th1s behavior would be expected from interetitial dielocation loops. 
nuber of loops were observed to be of this type at this irradiation temperature.

F1gures 20 throigh 25 (pages 70,71, 73, 74, 77, and 78) show that the effect of increasing the irradiation teaperature fron 370 to $470 \mathrm{C}$ at a constant fluence was to increase the loop size and dzcrease the loop density. Quantitative measurement of these parameters was impossible due to the complexty of the structure.

At ar Irradiation temperature of 570-630 C a dislocation network rather than faulted dislocation loops was formed. An electron aicrograph of this dislocation structure in a specimen irradiated at 570-630 C to $3.7 \times 10^{22}$ neutross $/ \mathrm{a}^{2}(\mathrm{E}>0.1 \mathrm{KeV}$ ) is shown in Figure 29. The dislocation line density in this naterial was approxinately $2 \times 10^{10}$ $c / c^{3}$. A few apparently unfaulted dislocation $100 p$ were aiso observed. This transition from a structure of fauled dislocation loops to a network of dislocation ines was a result of the difference in irradiation temperature. In this sane heat of type 304 stainless steel irradiated at tenperatures in the range of $370-470 \mathrm{C}$ the faulted dislocation $300 \mathrm{p}$ otructure was present.

\section{Volds and Swellirg}

At an irradiation temperature of $370-380$ C the lowest fast neutron fluence at which volds were detected was $2.0 \times 10^{2:}$ neutrons $/ \mathrm{cm}^{2}(\mathrm{E}>$ $0.1 \mathrm{HeV}$ ). In this specinen the concentration of visible volds was $8.5 \times 10^{14} \mathrm{volds} / \mathrm{cm}^{3}$. As can be 3 een in Pigure 30 , the volds range in size from the salleat observable (about 50 A dianeter) to approxisately 100 A diameter. exangation of fo:ls in which grown-lin dislocations 


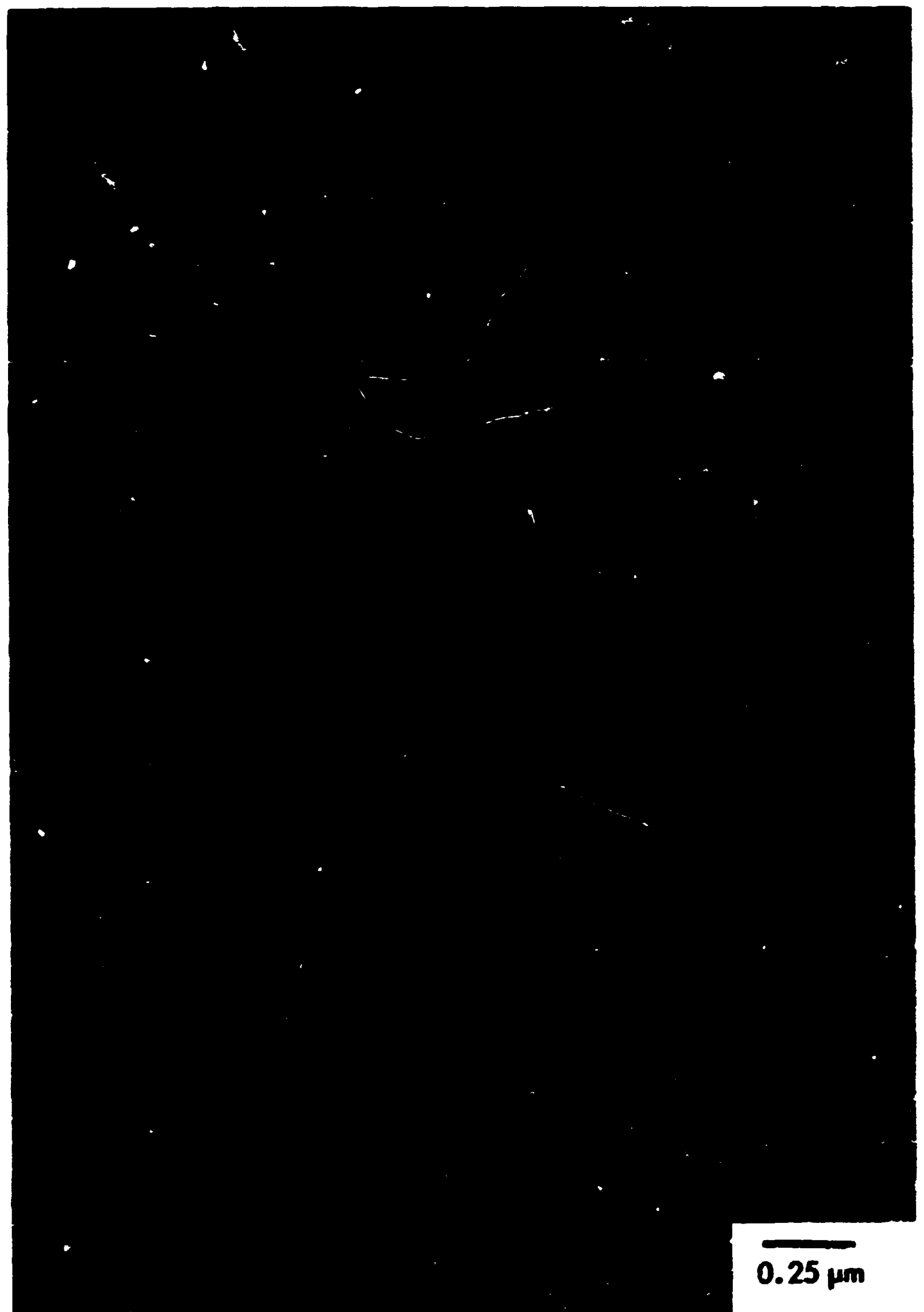

Figure 29. Dislocation netark in type 304 stainless steel Irradiated at $570-630^{\circ} \mathrm{C}$ to $3.7 \times 10^{22}$ neutrons $/ \mathrm{Cm}^{2}$ ( $\mathrm{E}>0.1 \mathrm{HeV}$ ). 


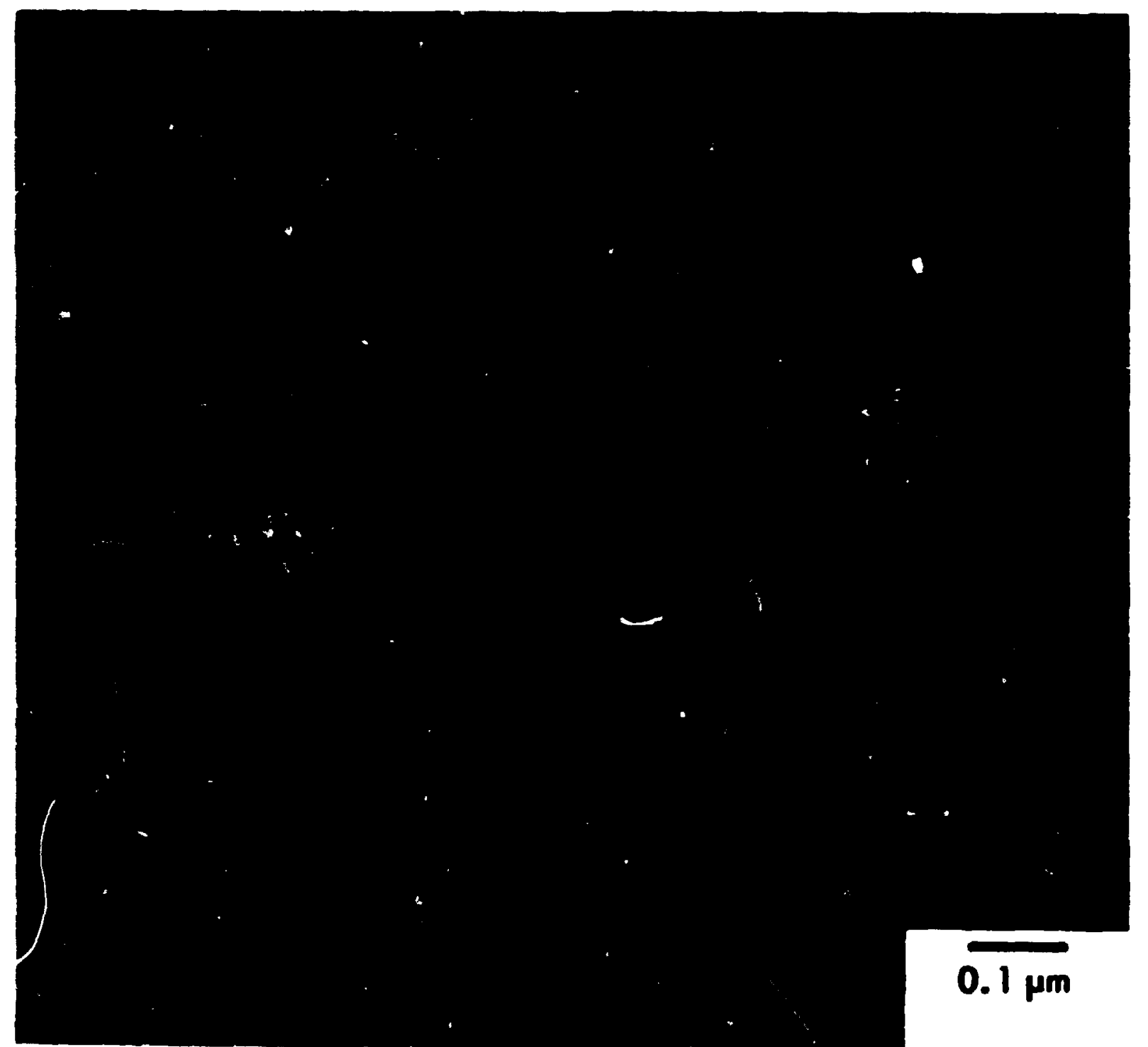

Figure 30. Voids in type 304 stainless teel Irradiated at $370-380^{\circ} \mathrm{C}$ to $2.0 \times 10^{21}$ neutrons $/ \mathrm{cm}^{2}$ (E $\left.>0.1 \mathrm{KeV}\right)$. 
were visible in residual contrast (Figure 30 ) revealed that voids vere of ten liscated on or very close to these dislocations.

The vold size, void shape and vold concentration were strongly dependent on the fast neution fluence. Figure 31 1llustrates the changes in the Irradiation produced voids when the irradiation tenperature vas held constant at $370-380^{\circ} \mathrm{C}$ and the fluence was increased from $4.8 \times 10^{21}$ to $5.0 \times 10^{22}$ neutrons $/ \mathrm{cm}^{2}(\mathrm{E}>0.1 \mathrm{veV})$.

It is readily apparent fron these photonicrographs that a distributior of yoid sizes is present. Secondly, as the fast neutron fluence is increased the void concentration increases. After irradiation to $4.8 \times 10^{21}$ neutrons $/ \mathrm{c}^{2}(E>0.1 \mathrm{HeV})$ and $1.2 \times 10^{22}$ neutrons $/ \mathrm{c}^{2}$ (FIgure $31 a$ and b) several void shapes with'n any one grain can be found. The analler voids appear spherical and the larger volds appear polyhedral. In the case of the polyhedral shsped voids no one forn or shape predominates. After Irradiation to the highest fluence, $5.0 \times 10^{22}$ neutrons/can (E > $0.1 \mathrm{MeV}$ ), many of the larger volds appear to have a common shape (e.g., In Pigure 31c the larger voids project as squares) suggesting that they are approaching some equilibriu shape. Void size distributions were deternined for a total of elght specinens irradiated at $370-380^{\circ} \mathrm{C}$. A typical histograph of the vold size distribution for one of these specimens 18 shown in Figure 32. At this irradiation teaperature the smallest size interval contains the larg'st percentage of voids. All visible volds fall into a narrow size range, having diameters between approximateily 60 and $170 \mathrm{~A}$. The vold size disiributions for the specimens shown in Figure 31 have been plotted in Figure 33. This plot 


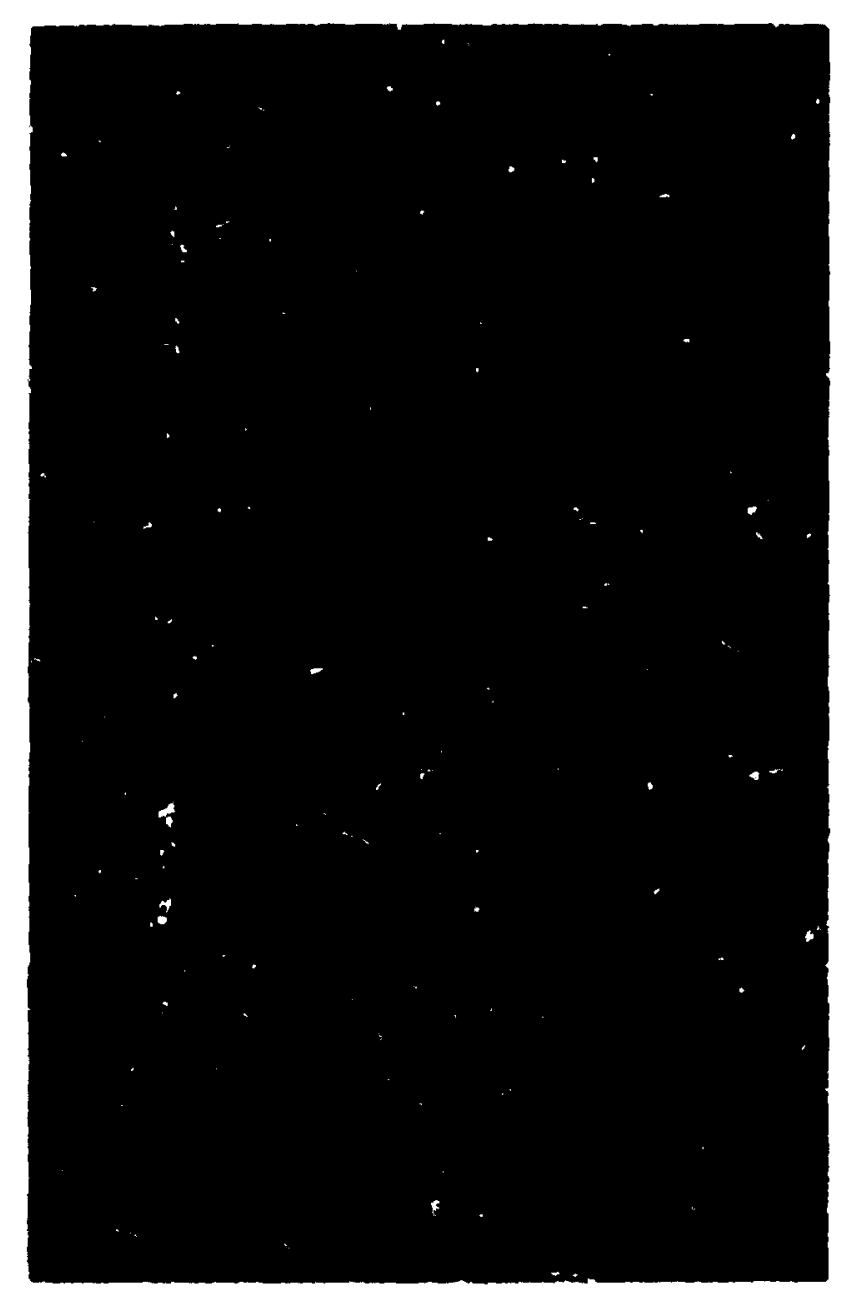

(a) $4.8 \times 10^{21}$ neutrons $/ \mathrm{cm}^{2}$ $(\mathrm{B}>0.1 \mathrm{MaV})$.

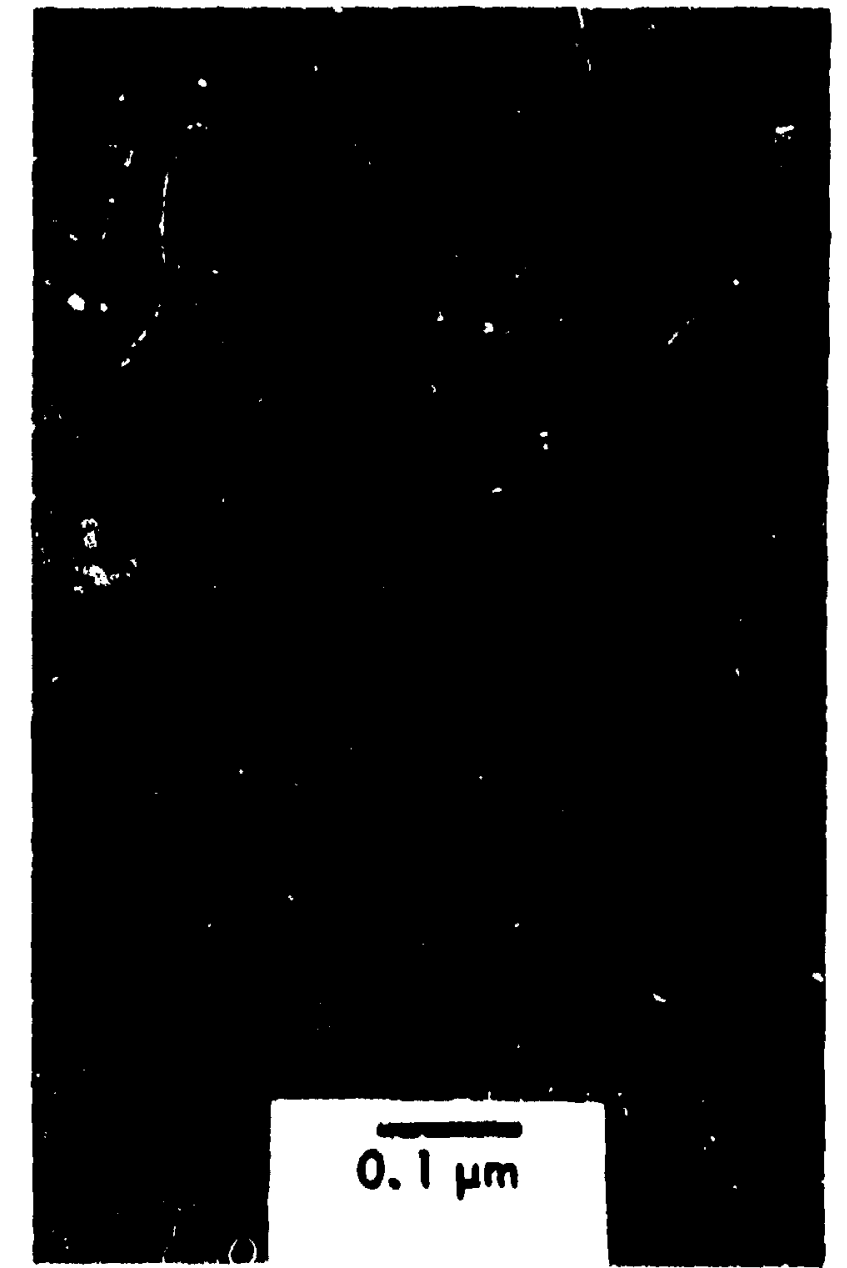

(b) $1.2 \times 10^{22}$ nautrons $/ \mathrm{cm}^{2}$ $(E>0.1 \mathrm{MCH})$.

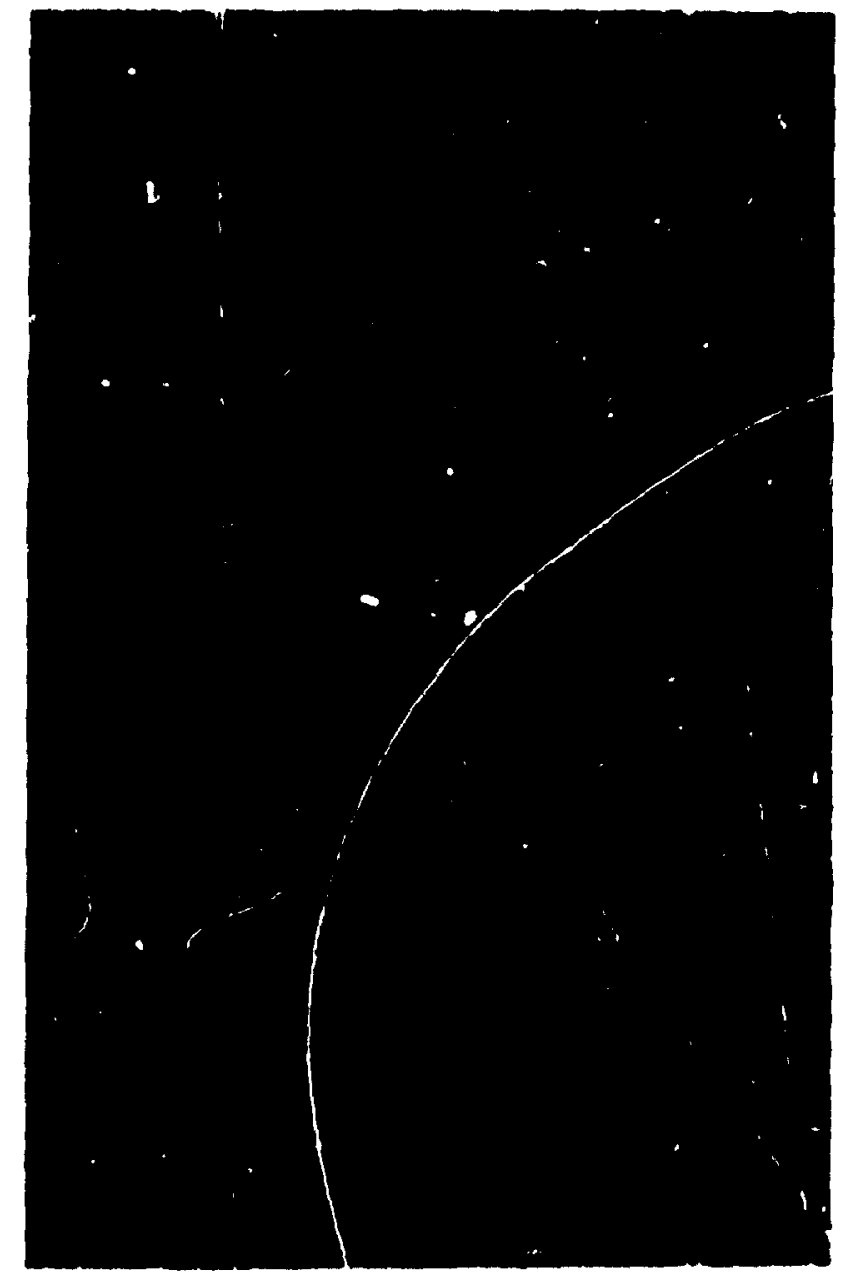

(c) $5.0 \times 10^{22}$ neutrona $/ \mathrm{cm}^{2}$ $(\mathrm{E}>0.1 \mathrm{MaV})$.

P1gure 31. Effect of fast neutron fluence on the vold conceatration and siza dietribution In type 304 stainless steel Irradiated at $370-380^{\circ} \mathrm{C}$. 


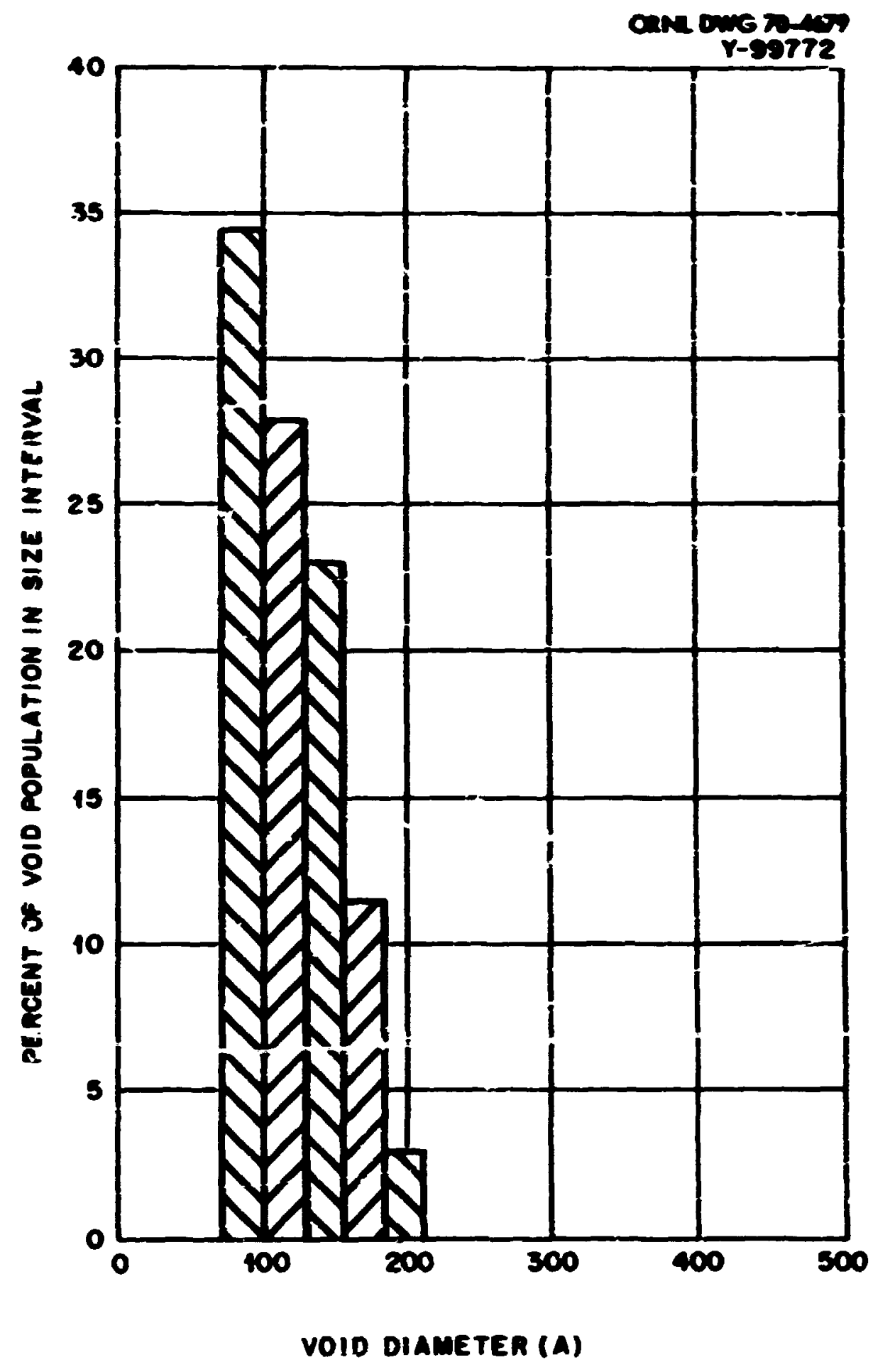

P1gure 32. Mistogran of the vold size distribution in type 304 stainless steel irradiated at $370-380^{\circ} \mathrm{C}$ to $5.0 \times 10^{22}$ neutrons/ca (E > $0.1 \mathrm{HeV}$ ). 


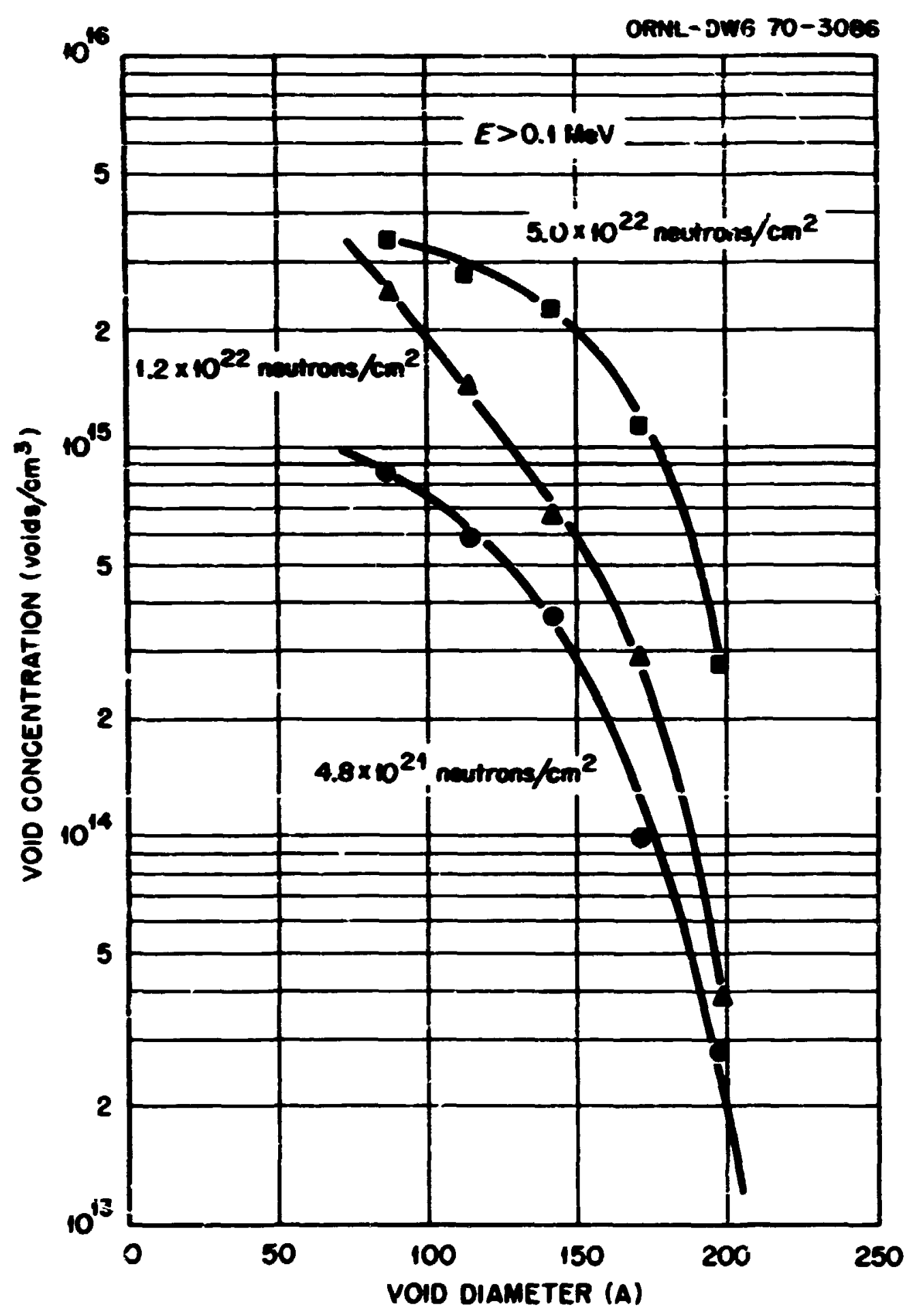

F1gure 33. Effect of fivence on the vold size distribution curve for type 304 stainless steel Irradiated at $370-380^{\circ} \mathrm{C}$. 
shoss the vold concentrition within a size interval as a function of the void dimeter. The points have been plotted at the center of the respective size intervals and smoth curves dran through them. The nost important feature of the distributions is that over a range of fluences from $4.8 \times 10^{21}$ to $5.0 \times 10^{22}$ neutrons $/ \mathrm{cm}^{2}(\mathrm{~B}>0.1 \mathrm{keV})$ the andine void size renains constant at approximately 200 A. After irradiation to $2 \times 10^{21}$ neutrons/ $\mathrm{c}^{2}$ the naxim vold size is saller, being near $100 \mathrm{~A}$. Irradiation at $460-470^{\circ} \mathrm{C}$ to relatively $10 \mathrm{~d}$ fast neutron fluences producei heterogeneous vold distributions sinflar to those observed after a low fluence Irradiation at $370-380^{\circ} \mathrm{C}$. Pigure 34 shows a specinen Irradiated at $460-470^{\circ} \mathrm{C}$ to approxinately $4 \times 10^{21}$ neutrons $/ \mathrm{Cl}^{2}$ (E >0.1 $\mathrm{HeV}$ ). Voids ere assoctated with dislocations, which can be seen in residual contrast. The fact that the voids lie on the dislocations vas confined by stero atcroscopy.

In Instances where the void was associated with line defects the vold shape was vory strongly affected. Figure 35 shows roids 1 ying on very straight dislocations. These volds have a crystallographic appearance in contrast to the votds which do not appear to be associated with dislocations. In geveral there was a teadency for volds 1 ing on dislocations to be elorgated in the direction of the dislocaticn ine.

After the higher fast neutron fluence, the vold concentration was higher and it becane progressively wore difficult to detect inhomgentties in the vold distributions. Pigure 36, however, shows a spectsen Irradiated to $0.74 \times 10^{22}$ neutrons $/ \mathrm{cm}^{2}$ ( $\mathrm{E}>0.1 \mathrm{MeV}$ ) at $460^{\circ} \mathrm{C}$. Several volds are assoclated with the dislocation linesand these volds tend to 


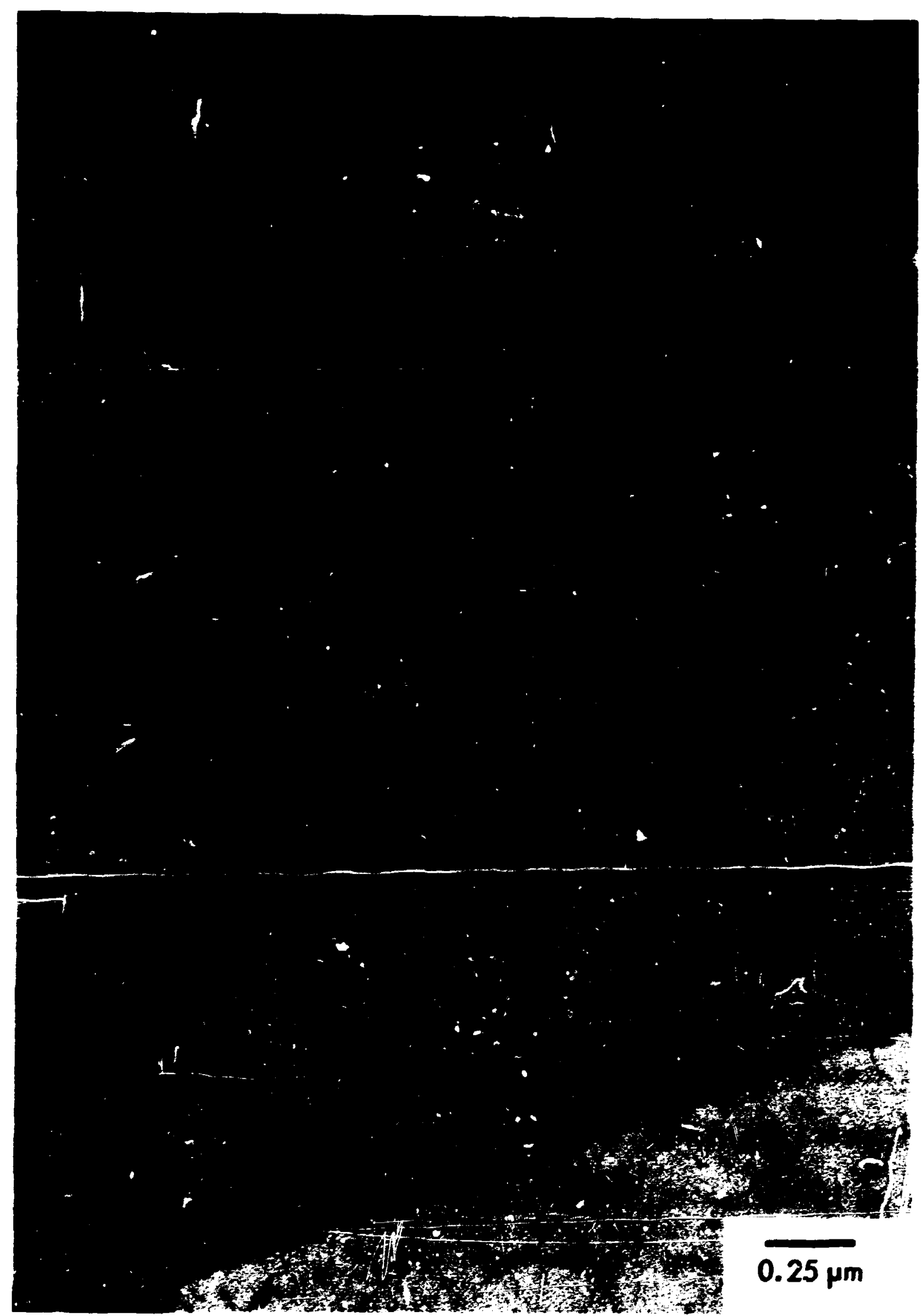

Figure 34. Heterogeneous vold distributions in type 304 stainless steel irradiated at $460-470^{\circ} \mathrm{C}$ to $4 \times 10^{21}$ neutrons $/ \mathrm{cm}^{2}$ (E $\left.>0.1 \mathrm{MeV}\right)$.

$$
\text { Stereo microscopy indicated that the volds lie on dislocation }
$$
11nes. 


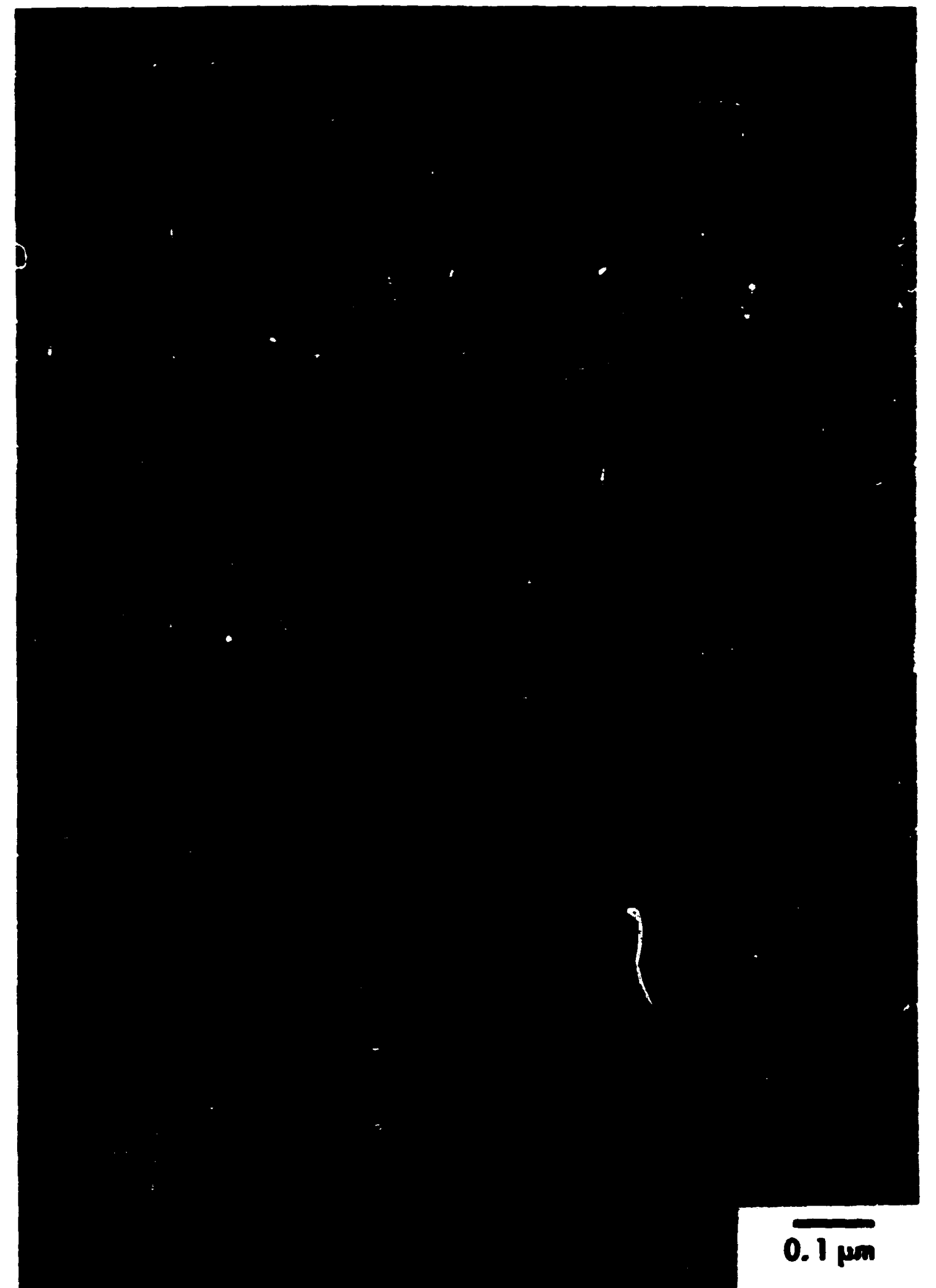

Plgure 35. Asectation of voide with dislocation lines in type 304 stainless steel.

Note the difference in shape of those volds which 11 en the dislocations compared to those which do not. 


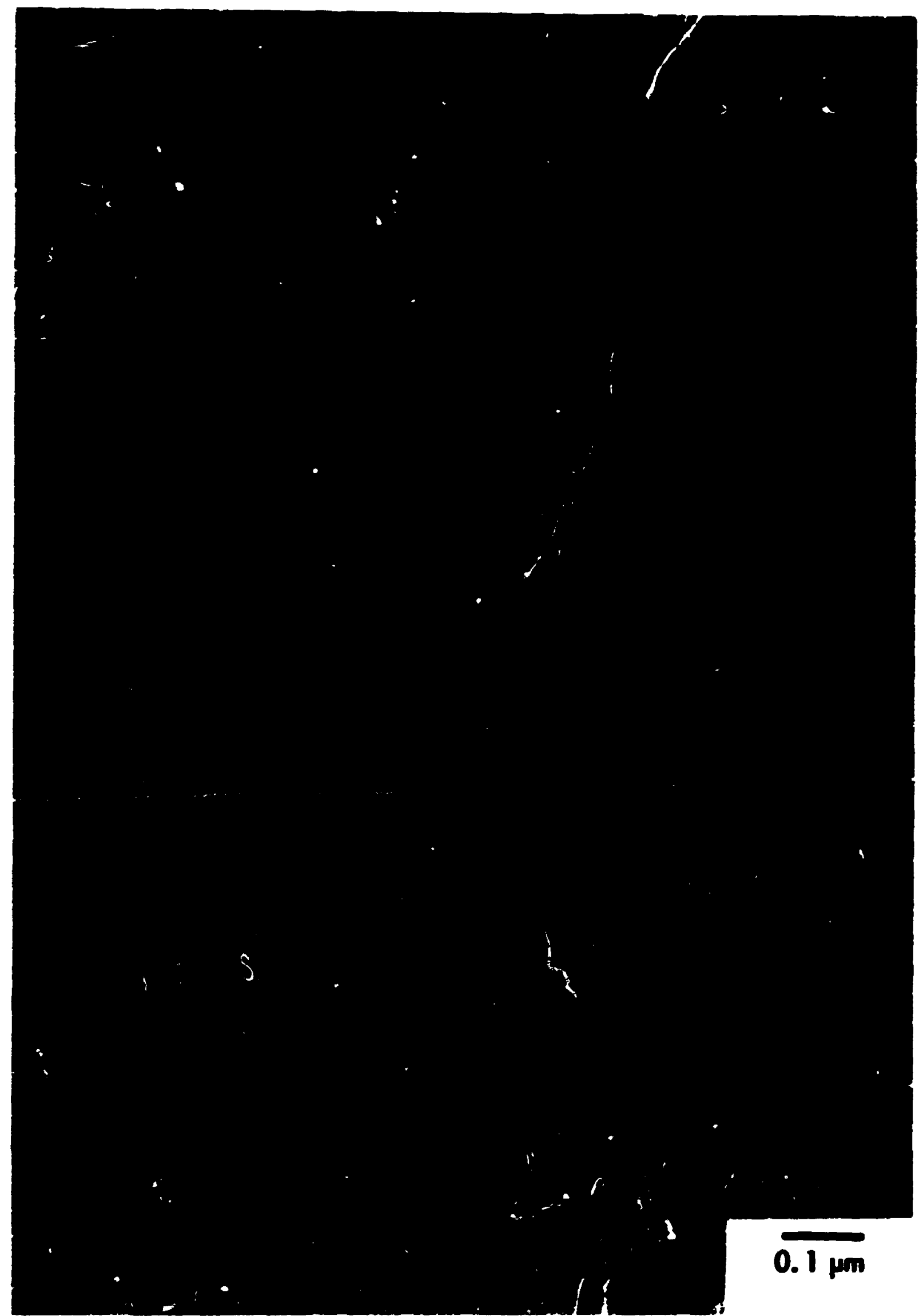

Figure 36. Volds associated with cislocation ines in speciakn Irradiated at $460-470^{\circ} \mathrm{C}$ to $0.74 \times 10^{22}$ rev.crons $/ \mathrm{cm}^{2}$ (E $>0.1 \mathrm{HeV}$ ). 
be elongated in the direction of the line, weres voids in the natrix have wore baffors ahepes ad project a spures or in some canes as circles.

In additon to berecogenteles in the wold distribution with the antrix which ware obeerved ader certaln irradiatloa condition, a secood beterogenty, nevely the lack of wold in a sose adjecent to the

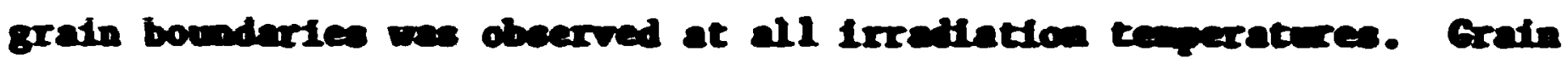

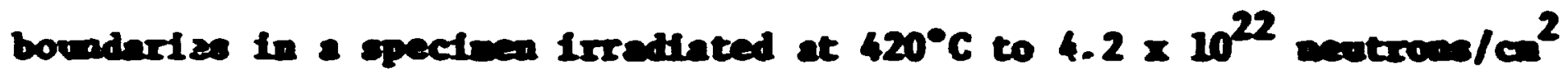
(B > $0.1 \mathrm{KaV}$ ) are shoin in Figure 37.

Plgure 38 show the effect of flonce on the appenrance of the voids in meterial irraliated at $660-470^{\circ} \mathrm{C}$. After irraitation to a civen neutron fluence the void concentration is ach reduced so conared to

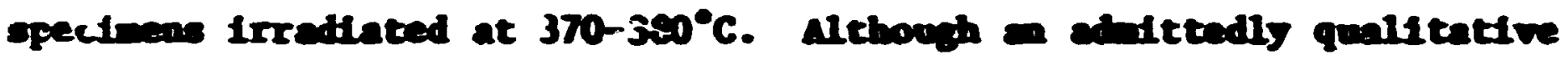

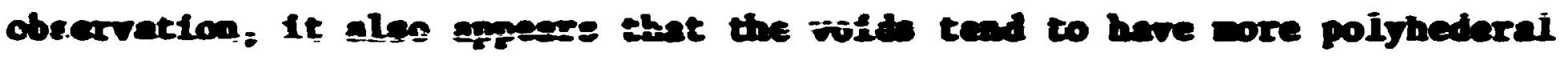
02 cryotalogrephic shapes then at the lower tepperature. Vold alze disnilbution were deternined for ef the apectene irradiated at $460-470^{\circ} \mathrm{C}$. The elongated volds ouch se those present in Figure 34 were not coneldered in deternining the eise distributiose. A typical histogran is shown in F1gure 39. In comparticon to the 10wer Irxadiation temerature (Figure 32, page 89) at $460-470^{\circ} \mathrm{C}$ the range of vold sisen is larger (approxiantely 60 to 300 A dianeter) and the interval containing the largent percentage of the voids is not the salleat size interval. A plot of three vold size distribution curves for specinens irradiated at $460-470^{\circ} \mathrm{C}$ is shown In Yigure 40. As was the case at the lower irredlation tenperature of 


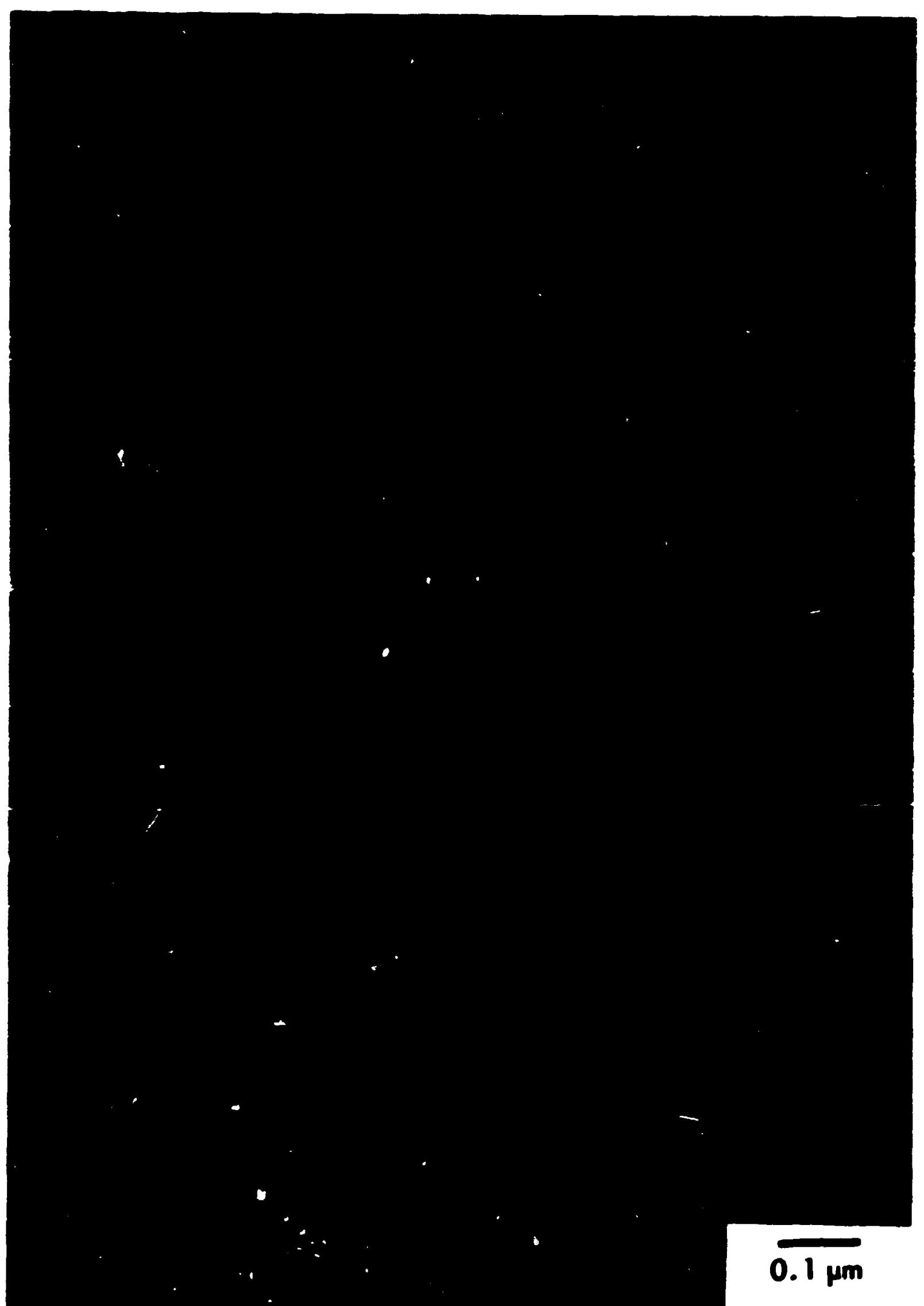

P1gure 37. Type 304 stainless steel irradiated at $420^{\circ} \mathrm{C}$ to $4.2 \times 1022$ neutrons $/ \mathrm{cm}^{2}(\mathrm{E}>0.1 \mathrm{MeV})$.

Note the reglows along grain boundarles are denuded of volds. 


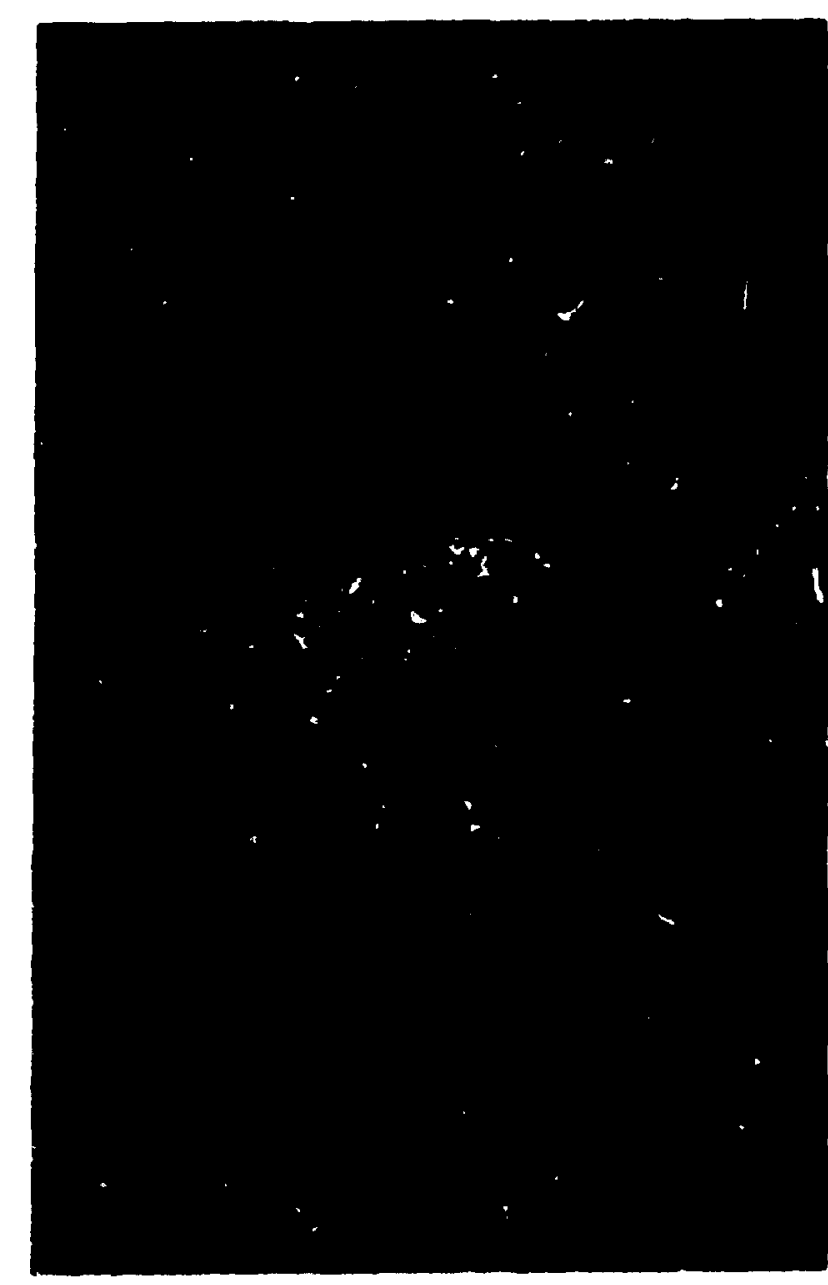

(a) $2.8 \times 10^{21}$ neutrons $/ \mathrm{cm}^{2}$ $(\mathrm{E}>0.1 \mathrm{MeV})$.

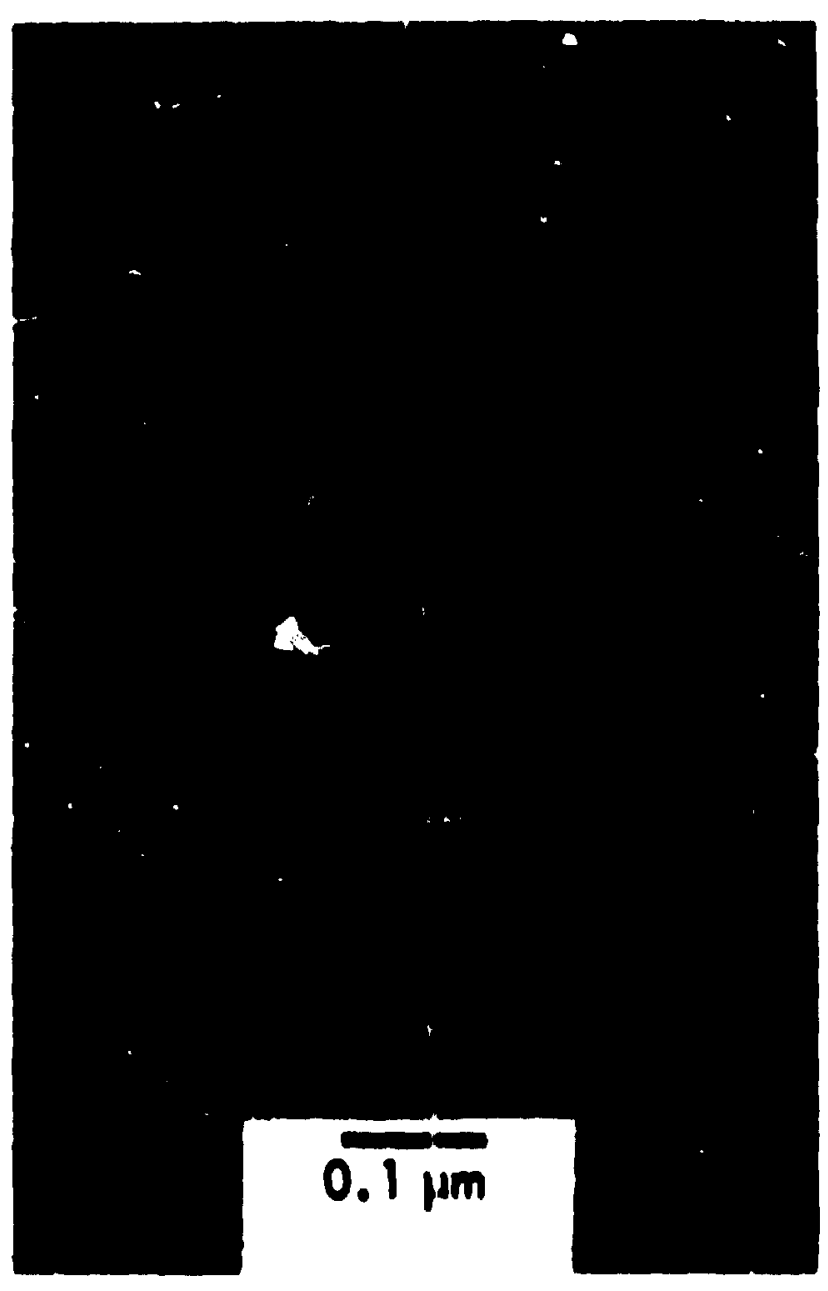

(b) $0.9 \times 10^{22}$ neutrone $/ \mathrm{cm}^{2}$ $(E>0.1 \mathrm{MaV})$.

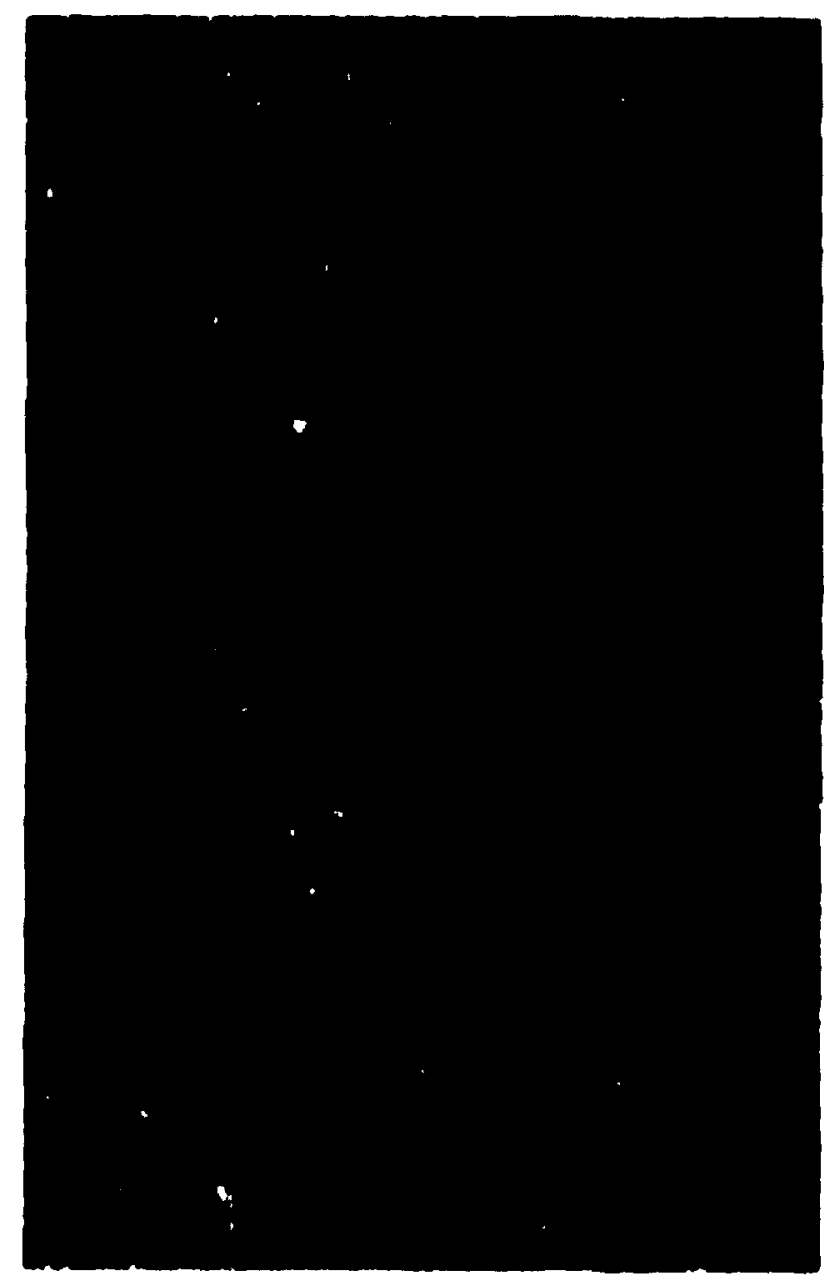

(c) $\therefore 1 \times 10^{22}$ neutrono $/ \mathrm{cm}^{2}$ $(\varepsilon>0.1 \mathrm{MaV})$.

Figure 38. Effect of fast neutron fluence on the shape and concentration of voldo in sype 304 stalr. leee steel 1rradiated at $460-470^{\circ} \mathrm{C}$. 


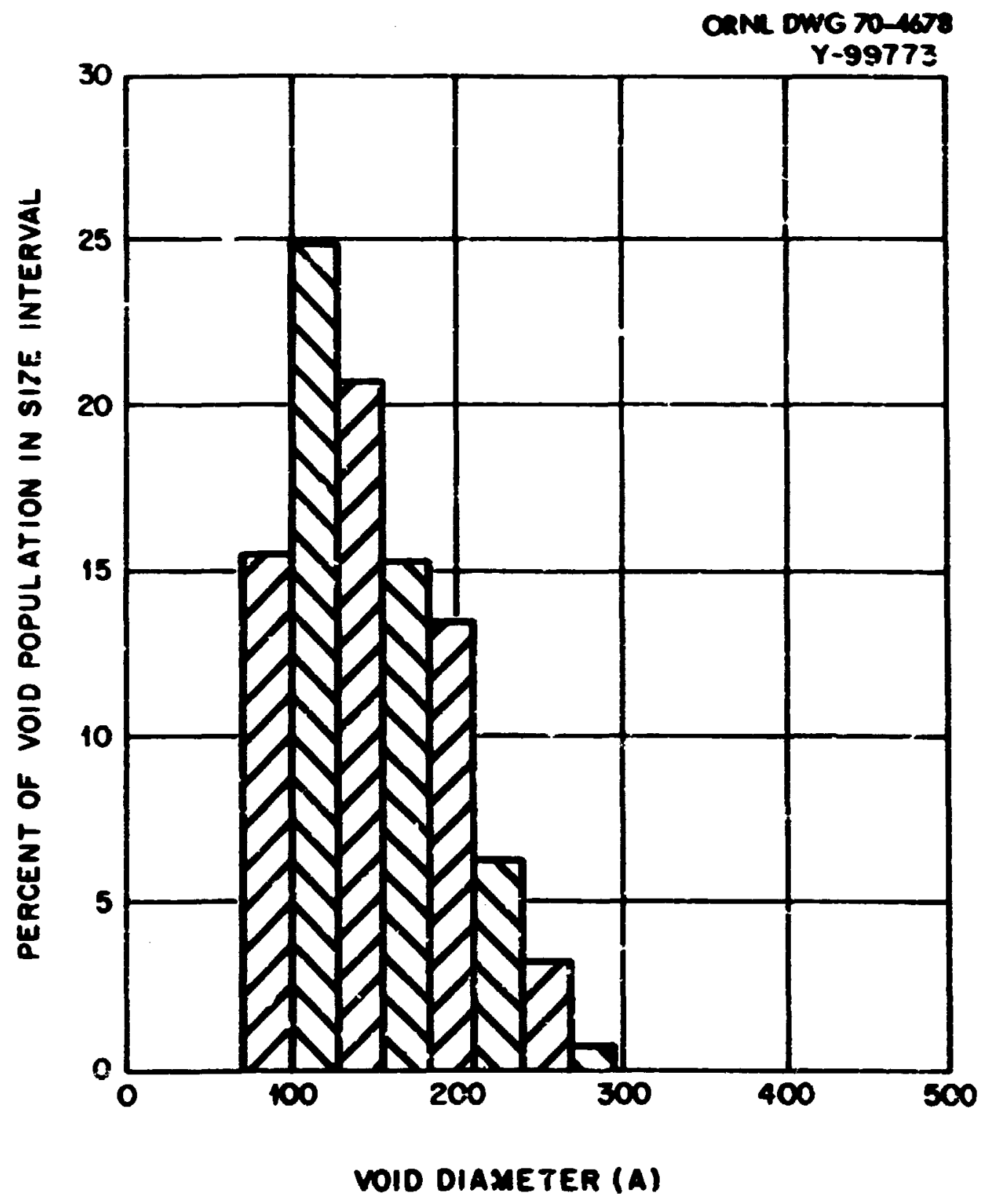

Figure 39. Hiatogran of the vold size distrfbution in type 304 stainless steel irradiated at $400-470^{\circ} \mathrm{C}$ to $2.1 \times 10^{22}$ neutrons/cas $(B>0.1$ HeV $)$. 


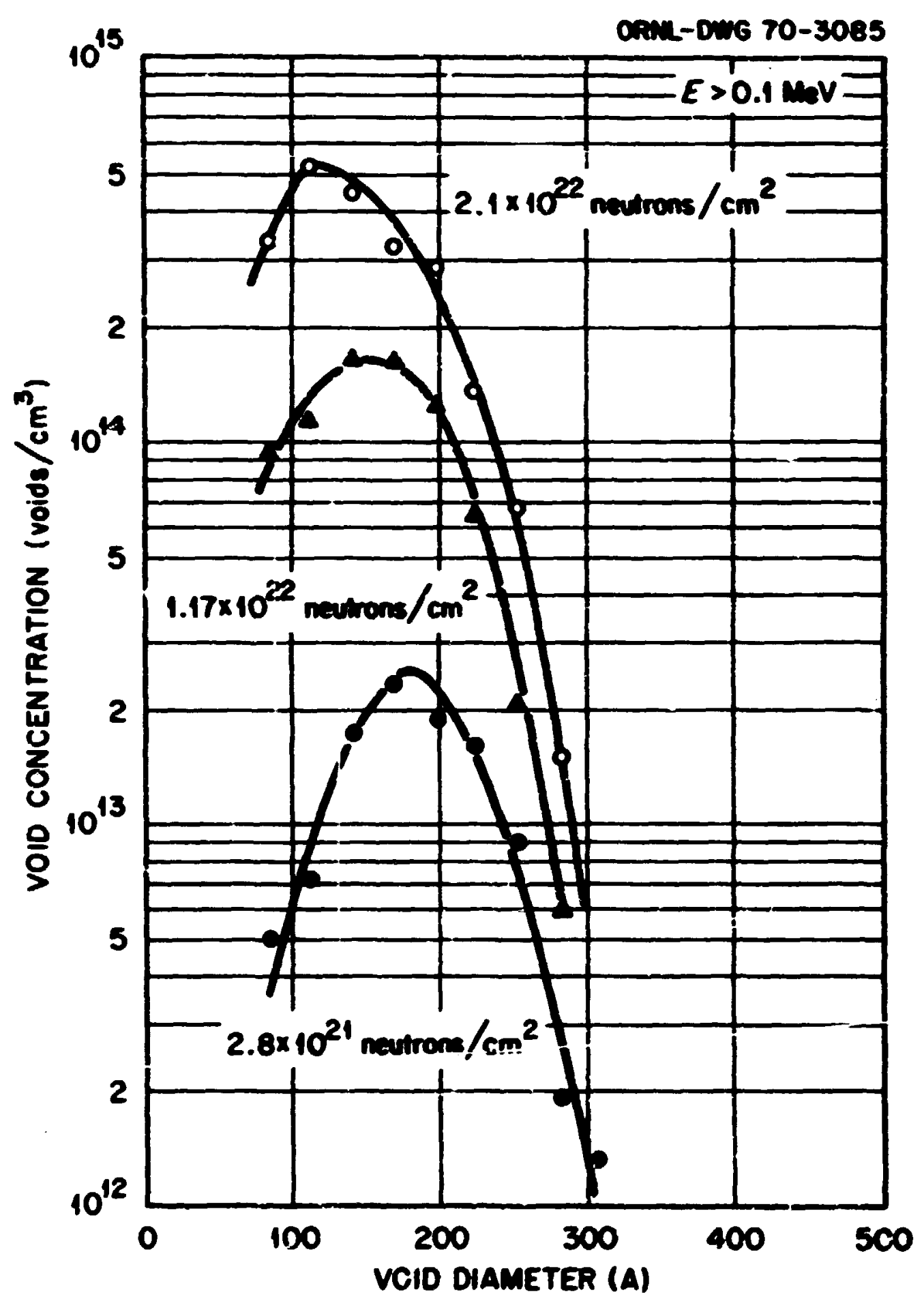

P1gure 40. Effect of fast neutron fluence on the vold e1ze distrivution in type 304 stalnless steel irradiated at $460-470^{\circ} \mathrm{C}$. 


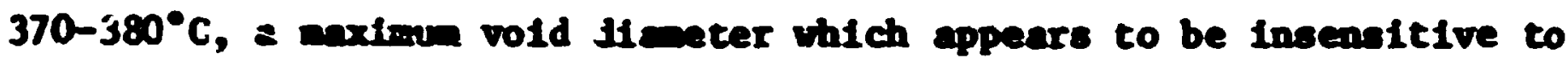
the fast neutron fluence is slso achieved at $460-470^{\circ} \mathrm{C}$.

The effect of irradiation teperature sn the vold structure is 11lustrated In PIgure 41 which shows volds present in specinens irradiated to fluences in the range of $3.75-4.0 \times 10^{22}$ neutrons $/ \mathrm{cm}^{2}(\mathrm{~B}>0.1$ We $V$ at temperatures of $370-380^{\circ} \mathrm{C}, 430-440^{\circ} \mathrm{C}, 570-630^{\circ} \mathrm{C}$, and $770-840^{\circ} \mathrm{C}$.

Several observations relating to the effect of irradiation teaperature were ade. At this fluence, the vold concentration was approxinately the ane in opectnex irradiated at $370-380$ and $430-440^{\circ} \mathrm{C}$ but was eigrificanty lower in the spectmen Irrediated at $570-630^{\circ} \mathrm{C}$. With Increasing Irradiation temperature the volde becem larger and in general eppear to have are unforn polyhederal shapes.

$\Delta$ in the case of spections irradiated to relatively $10 \mathrm{w}$ fluences In the temperature range of $370-470^{\circ} \mathrm{C}$ (see PIgures 30,34 and 35, pages 86, 92 and 93), near1y all the vol's in the spacinen 1xradiated at 570$630^{\circ} \mathrm{C}$ to $3.7 \times 10^{22}$ neutrons $/ \mathrm{cm}^{2}(\mathrm{E}>0.1 \mathrm{keV})$ vere aseoclated with dislocation lines. The dislocitson structure differed inasuch as the lower Irradiation temperature the dislocations were present prior to Irradiation wile at the higher temperature the dislocations were apparently produced by the Irradiation.

The specinen 1 rradiated at $770-840^{\circ} \mathrm{C}$ contained approsinately

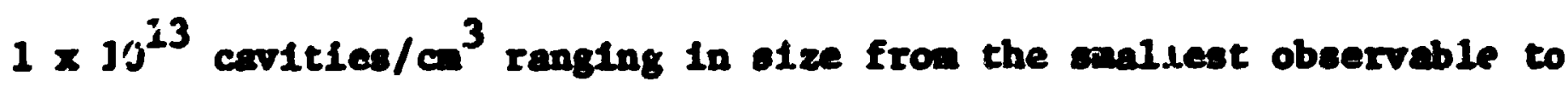
approximately $75 \mathrm{~A}$ dianter. In several instences the cavities were located on large preclpitate particles and also at graln boundaries. Theoe cavities are iliherently different fros the volds which forned 

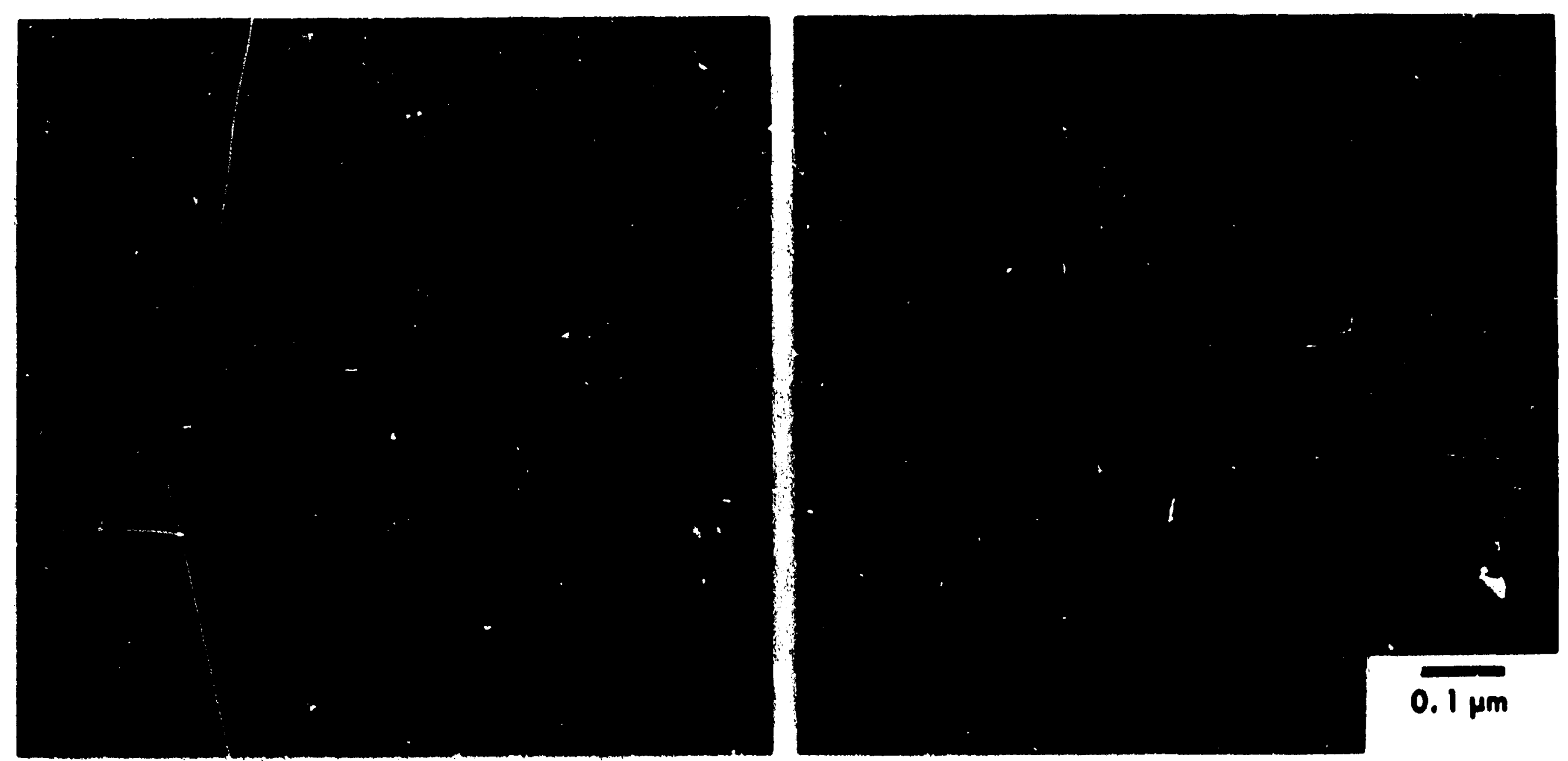

(a) Irrediated at $370-390^{\circ} \mathrm{C}$.

(b) Irrad1ated at $430-440^{\circ} \mathrm{C}$.

I1gure 41. Iffect of 1rrediation temporature on the vold concentration and else in type 304

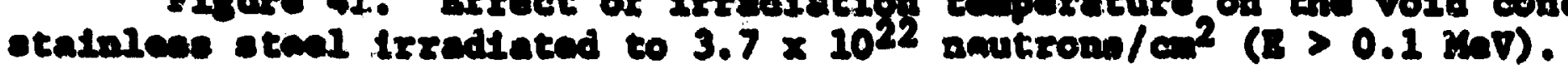

At $770-840^{\circ} \mathrm{C}$ hallum bubblea rathor than volde wero formed. 

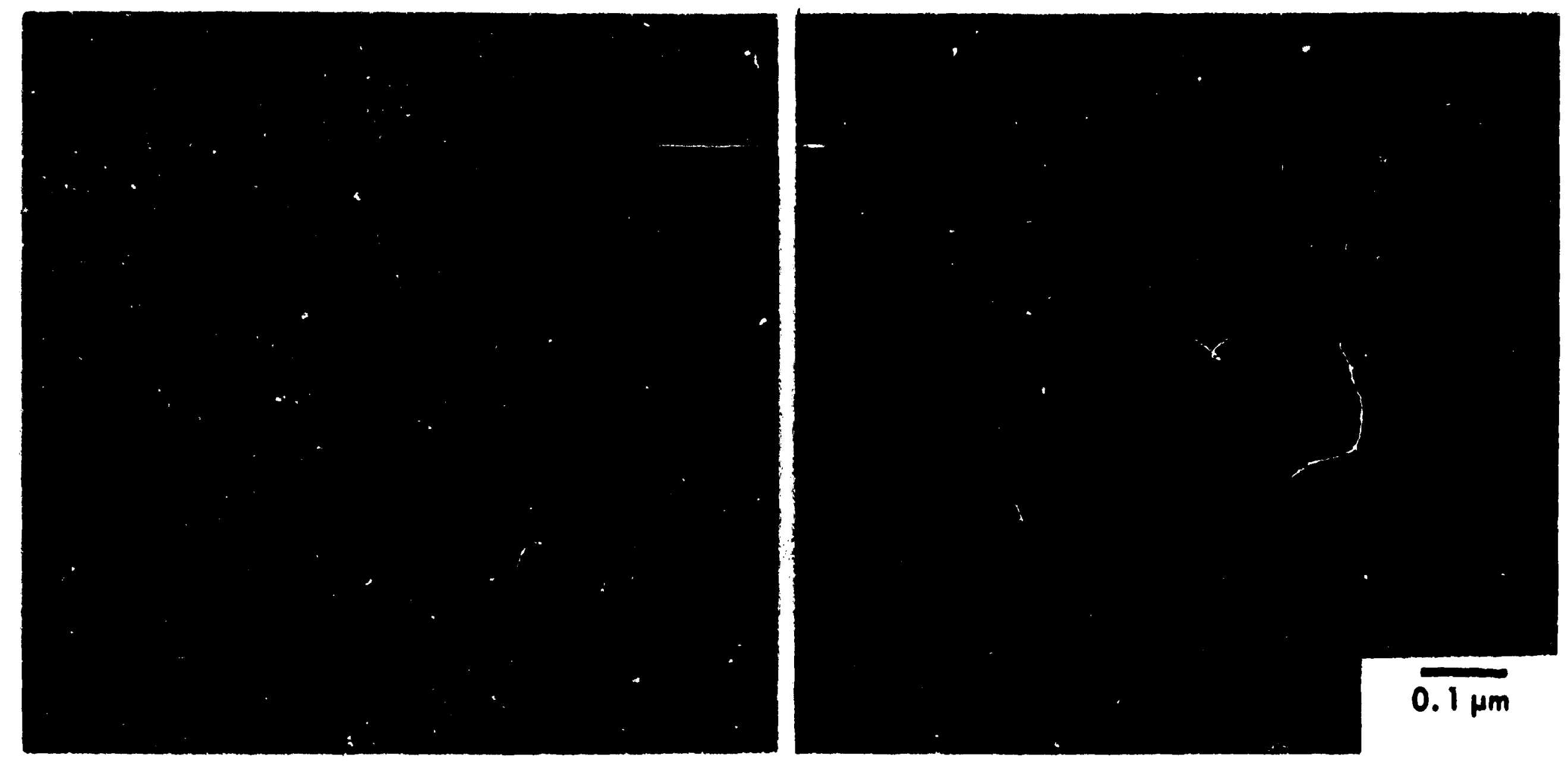

(c) Irradiatad at $570-630^{\circ} \mathrm{C}$.

(d) Irrediated at $770-840^{\circ} \mathrm{C}$.

P1gure 41 (continued) 
at lower temperatures since voids bave never been seen at precipitate particle-ratrix interfaces nor at grain boundaries. In addition, the high temperature cavities were snaller than the woids wich formed at a Iorer Irradiation tesperature. The high temperature cavities thus have the characteristics reported previously for helliw bubble's $(17,18,19,20)$.

The yoid conceutration and void size distribution was deternined for each irradiated specimen. These results are presented as plots of void concentration and aximan void size as a function of fluence for a constant irradiation temerature and as a function of irradiation temperature for a conetant fast neutron fluence.

Pigure 42 shows the vold concentration as a function of the fast neutron fluence for specimens irradiated at $370-380$ and $460-470^{\circ} \mathrm{C}$. At each temperature the vold concentration increased motonically with Increasing fluence. Over the range of fluence for which data is available the vold concentration increased at a faster rate and the concentrations were 10 ver at $460-470^{\circ} \mathrm{C}$ than at $370-380^{\circ} \mathrm{C}$. This wist wean that at still lower fluences ( $1 . e ., 1$ less than $10^{21}$ neutrons/ca ${ }^{2}$ [B $>0.1 \mathrm{MeV}$ ]) the vold concentration was increasing at a faster rate at $370-380^{\circ} \mathrm{C}$ than at $460-470^{\circ} \mathrm{C}$. A least square fit of the data show in Fiure 42 gives a variation of void concentration with fluence (1.e., the value of $B$ in the expression $\left.p_{v}=\Delta(\phi t)^{B}\right)$ of 0.66 at $370-380^{\circ} \mathrm{C}$ and 1.66 at $460-470^{\circ} \mathrm{C}$. Sufficient data were avallable to define the form of the curve of void concentration as a function of irredintion tenperature for a fast neutron fluence of $3.7-4.0 \times 10^{22}$ neutrons/ $\mathrm{cm}^{2}$. Additionsl curves were then constructsd from linited date avasiable at fluences of $5 \times 10^{21}$ 


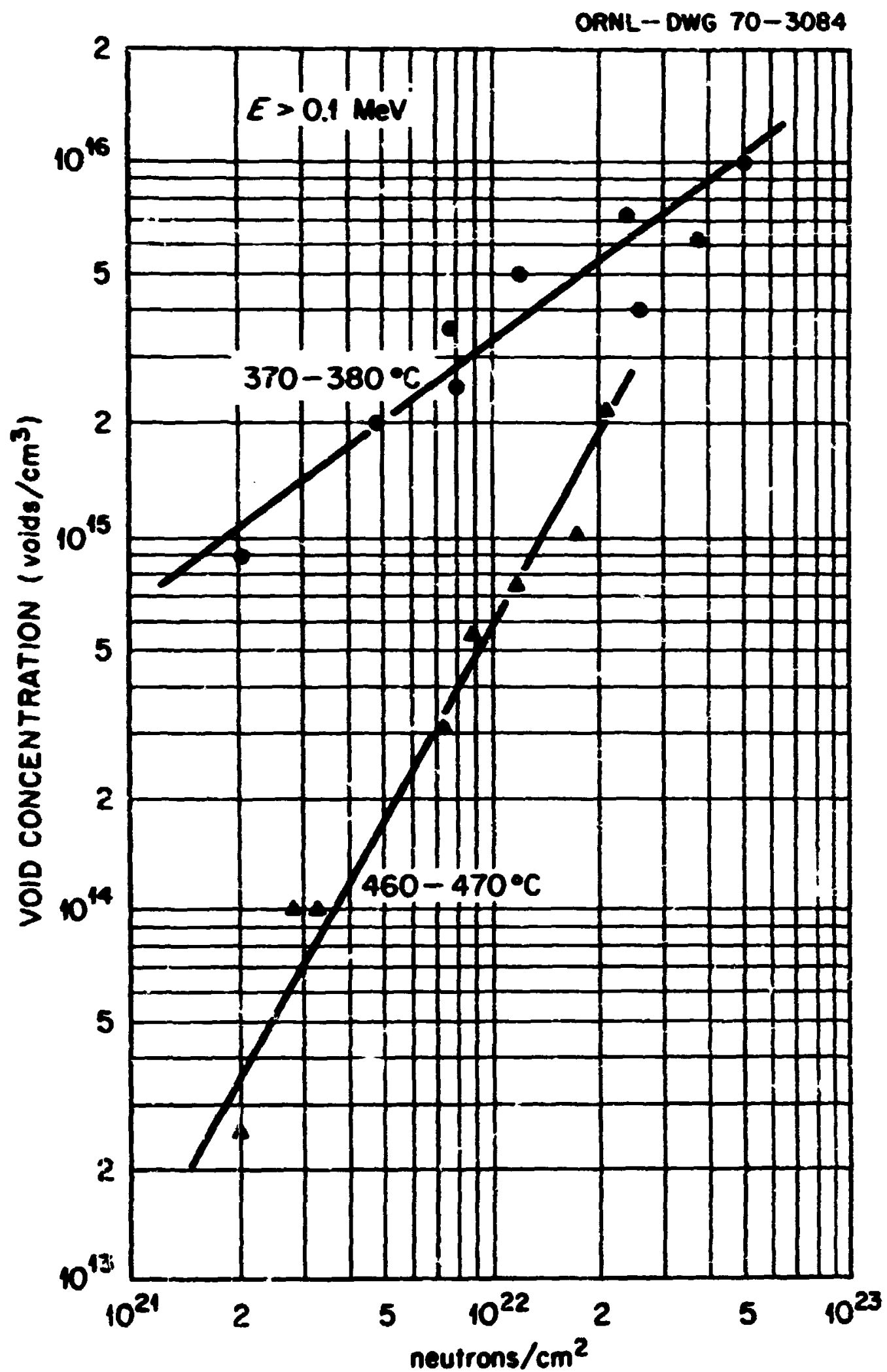

P1gure 42. Varlation of vold concentration with fast neutron fluence in type 304 stainless steel irradiated at $370-380$ and $460-470^{\circ} \mathrm{C}$. 
and $1.2 \times 10^{22}$ neutrons $/ \mathrm{cm}^{2}(\mathrm{~B}>0.1 \mathrm{MeV})$. At each fluence level the vold concentration decreased with increasing irradiation temerature, Figure 43. This decrease in void concentration with increasing temperature occurred nore rapidly at low fluences than at higher fluences. At a fluence of $3.7-4.0 \times 10^{22}$ neutrons/ $\mathrm{cm}^{2}$ the vold concentration is nearly constant at irradiation temperatures betreen 370 and $450^{\circ} \mathrm{C}$.

Several of the exanined specinens had been irradiated to approxiwately the same fast neutron fluence but at fast neutron fluxes which different by as wuch as a factor of six. The vold concentrations for these specimens are listed in Table IV. Within the experimental error associated with these messurements, the vold concentration did not depend on the value of the fast neutron flux. Void size distribution curves were also exanined and did not appear to be Influenced by the flux.

The aaxim vold dianeter 18 plotted as a function of fast neutron fluence for spectmens 12:alluted at $370-380^{\circ} \mathrm{C}$ and $460-470^{\circ} \mathrm{C}$ in Pigure 44 . At $370-380^{\circ} \mathrm{C}$ no volds were observed after irradiation to $1.4 \times 10^{20}$ neutrons/ $\mathrm{cm}^{2}$ ( $\mathrm{E}>0.1 \mathrm{MeV}$ ) and volda having a naxinu dieneter of approxdmately 100 A were observed after Irradiation to $2.0 \times 10^{21}$ neutrono/ ${ }^{2}$ (E > $0.1 \mathrm{MeV})$. Over the range of fluence from $5 \times 10^{21}$ to $5 \times 10^{22}$ neutrons $/ \mathrm{CO}^{2}$ ( $\mathrm{E}>0.1 \mathrm{KeV}$ ) the maximu vo 1 size changed very little, renaining esseritially constant at 200 A dieneter. It thus appears that a vold grows quite rapidly early in its life but that after approxdmatsly $5 \times 10^{21}$ neutrons/ $\mathrm{cm}^{2}$ the growth rate decreases very sharply thus giving an apparent raxioun or liniting vold size. A sinilar argunent can be 


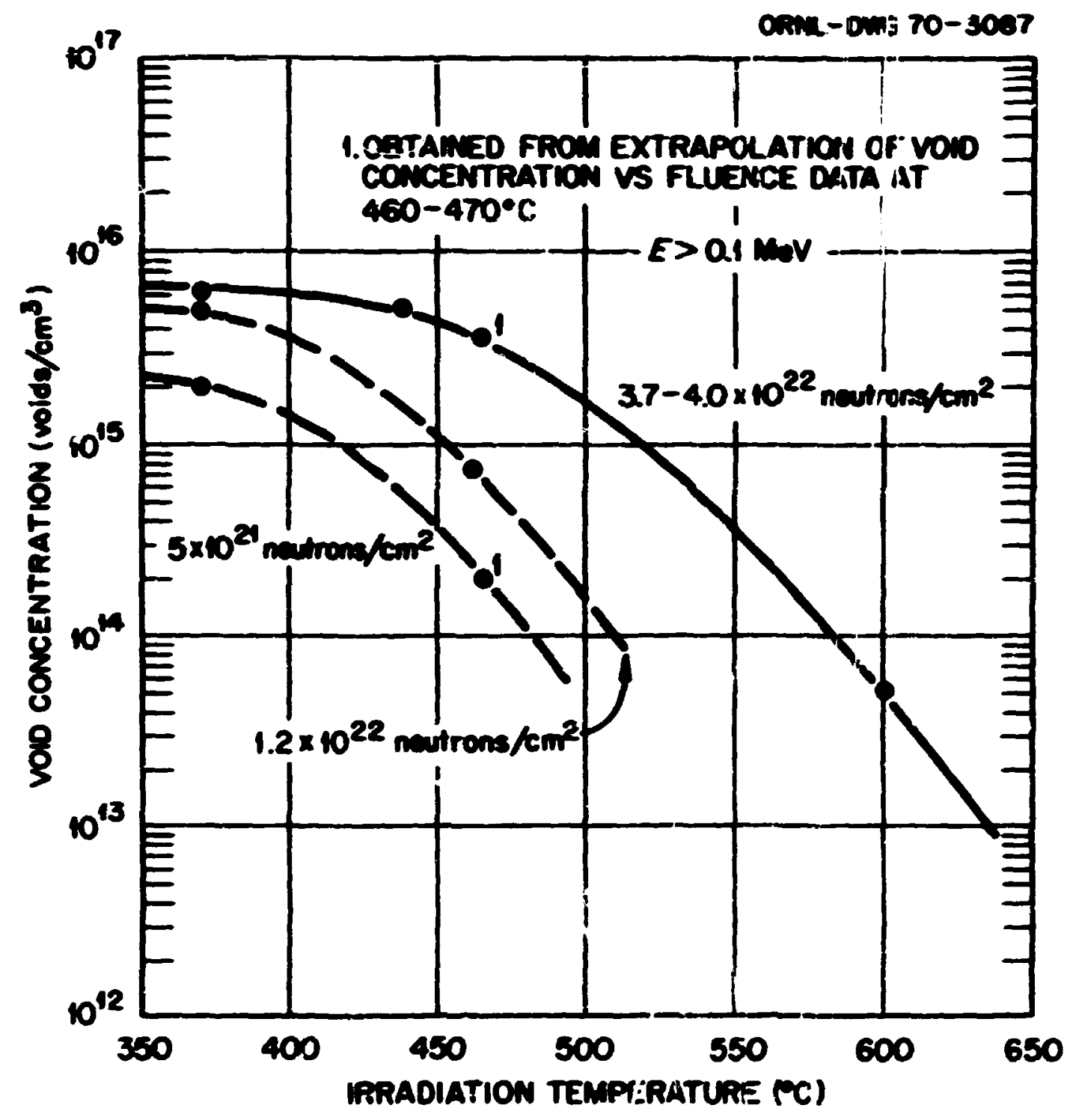

Fgure 43. Pariation of vold coacentration with irradiacion temperature. 
TARIS IV

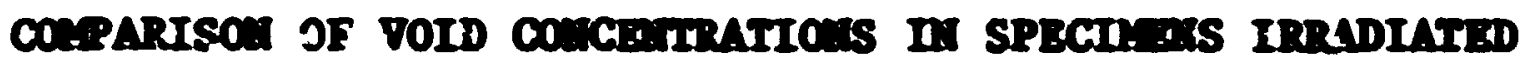

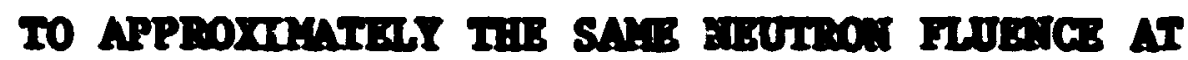

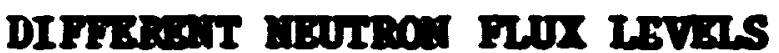

\begin{tabular}{|c|c|c|c|}
\hline $\begin{array}{l}\text { Irradiation } \\
\text { Temperature } \\
{ }^{\circ} \mathrm{C} \\
\end{array}$ & $\begin{array}{l}\text { Beutron } \\
\text { Pluence } \\
\text { Heutrons/cm } 2 \\
\mathrm{~B}>0.1 \mathrm{HeV} \\
\end{array}$ & 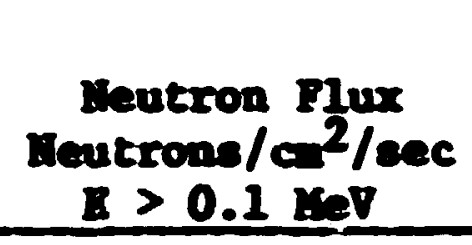 & $\begin{array}{l}\text { Vold } \\
\text { Concentratson } \\
\text { Voide/co }\end{array}$ \\
\hline 370 & $0.80 \times 10^{22}$ & $1.4 \times 10^{15}$ & $2.5 \times 10^{15}$ \\
\hline 370 & $0.76 \times 10^{22}$ & $2.1 \times 10^{14}$ & $3.6 \times 10^{15}$ \\
\hline 472 & $0.9 \times 10^{22}$ & $1.2 \times 10^{15}$ & $4.0 \times 10^{14}$ \\
\hline 465 & $0.9 \times 10^{22}$ & $3.7 \times 10^{14}$ & $5.5 \times 10^{14}$ \\
\hline 465 & $2.3 \times 10^{22}$ & $1.8 \times 10^{15}$ & $9.0 \times 10^{14}$ \\
\hline 462 & $1.2 \times 10^{22}$ & $3.3 \times 10^{14}$ & $7.5 \times 10^{24}$ \\
\hline
\end{tabular}




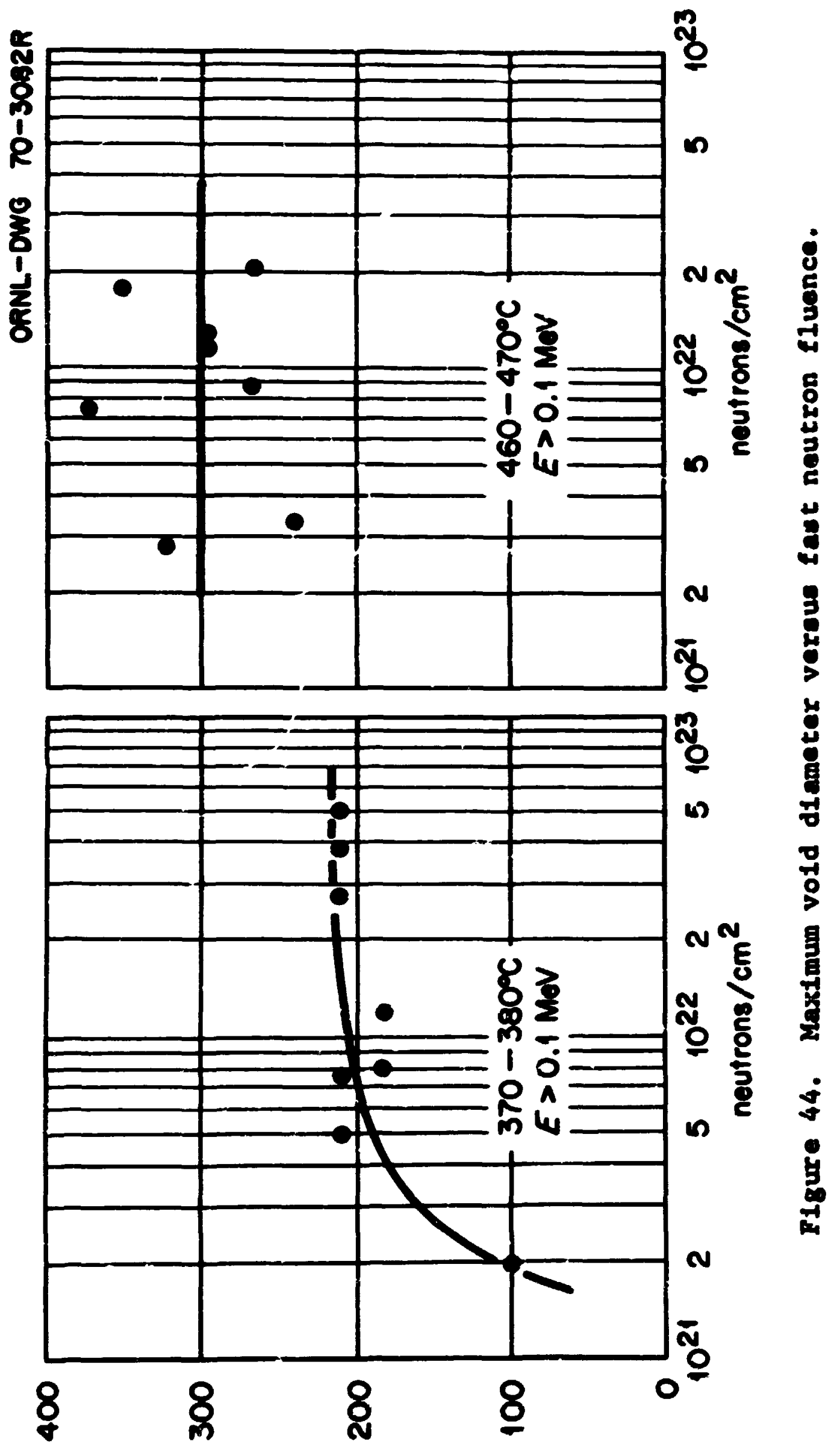

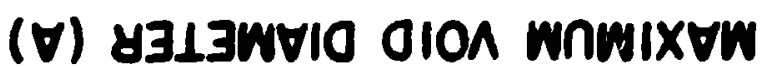


aade for specinens Irradiated at $460-470^{\circ} \mathrm{C}$. However, at the higher temperature the maxirum void size is larger, being approximately $300 \mathrm{~A}$ dianeter. Maximu void diameter as a function of irradiation temperature is shown in Figure 45.

\section{BFPECTS OF HELIOM ON IRRADIATION DAMAGE}

In order to deternine any role of transmutation produced heilum on the Irradiation dange processes, a specinen of type 304 stainless steel was injected with $20 \times 10^{-6}$ aton fraction hellum prior to irradiation at $390^{\circ} \mathrm{C}$ to $7.4 \times 10^{21}$ neutrons/ca ( $>0.1 \mathrm{HeV}$ ) in the BBR-II. The damage structure in this specinen was comared to that in a specimen Irradiated at identical conditions but which did not contaln heliu prior to irradiation.

The pre-irradiation afcrostructure of the specimen containing $20 \times 10^{-6}$ atom fraction hellum showed no evidence of damge which aight have resulted fron the o-particle bombardment.

Figure 46 shows the postirradiation nicrostructure of the specinen which contained no cyclotron infected hellum prior to irradiation. Approximately $2.4 \times 10^{15} \mathrm{volds} / \mathrm{cos}^{3}$ ranging in size from the smallest observable (approximately $40 \mathrm{~A}$ diameter) to a maxtmun of $130 \mathrm{~A}$ dianeter were present. There was a zone approximately $1000 \mathrm{~A}$ wide adjacent to the grain boundaries which was denuded of volds. This sone was also denuded of the 100p structure, Figure 46b. There was some evidence of loop formation immediately adjacent to the grain boundariea. sinilar observations of a sone denuded of dislocation loope near grata 


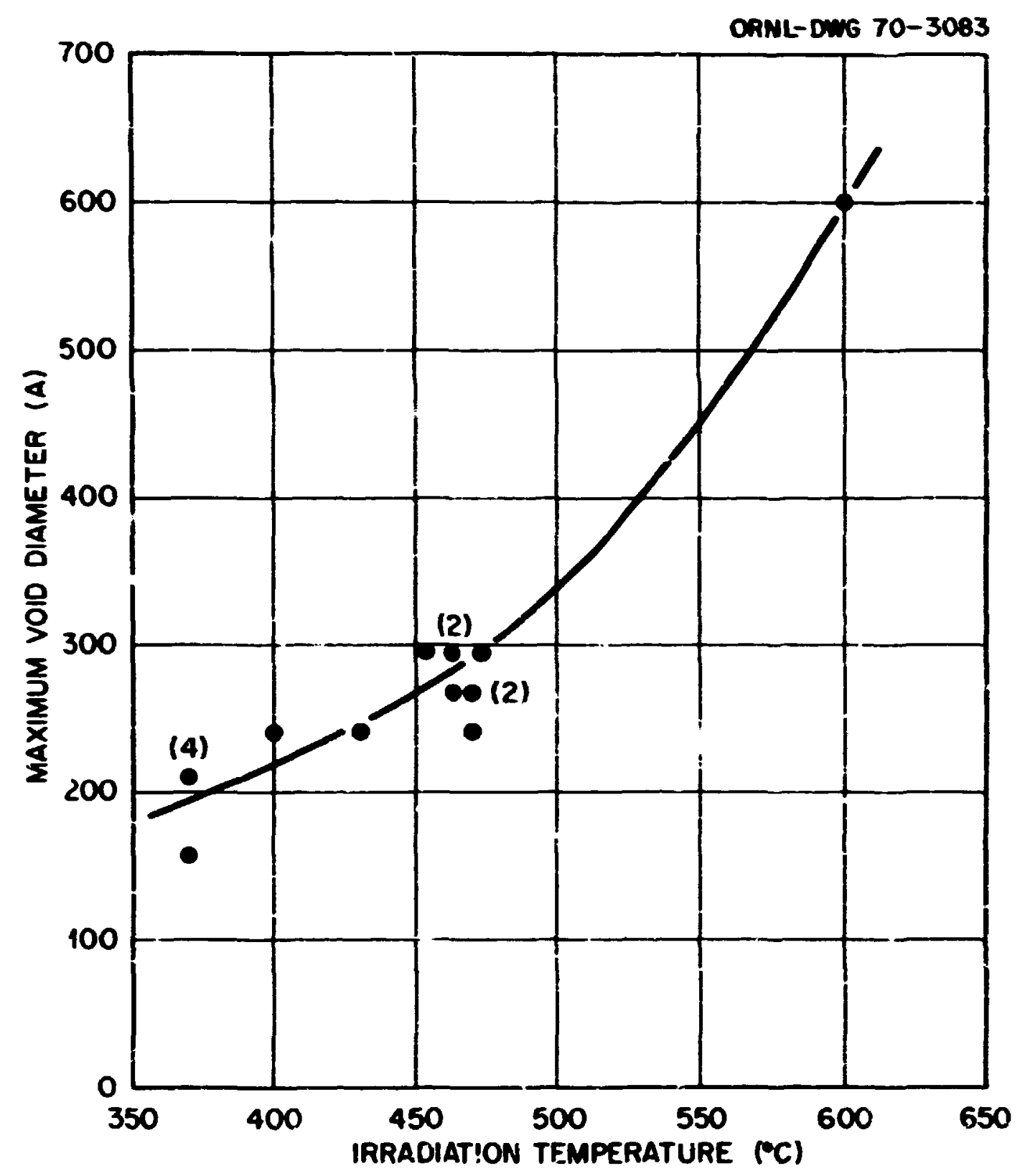

Figure 45. Maximum vold diameter as function of irradiation temperature for specimens irradiated to fast neutron iluences in excess of $1 \times 10^{22}$ neutrons $/ \mathrm{cm}^{2}(\mathrm{E}>0.1 \mathrm{NieV})$. 


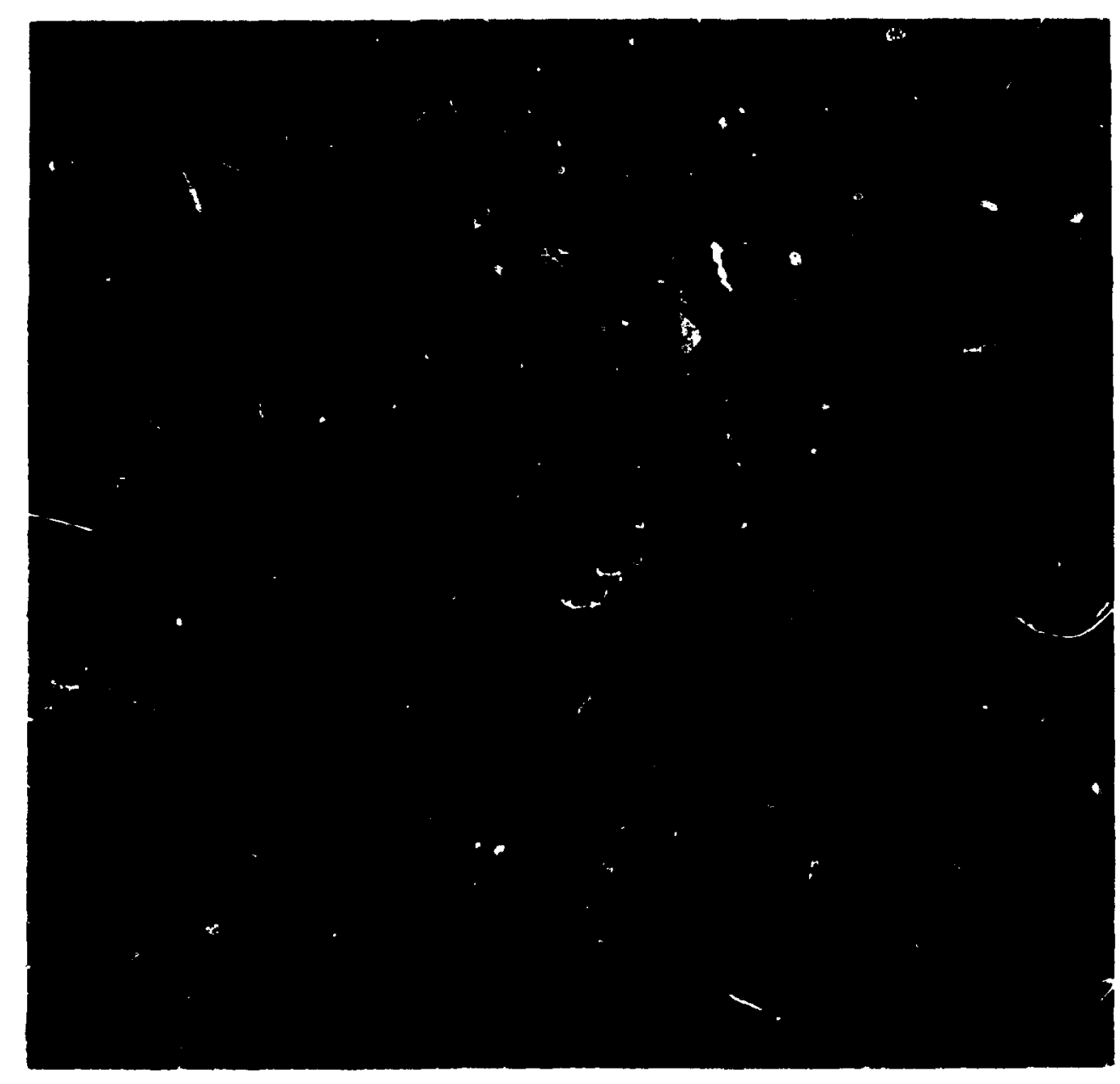

(a) Volds. Note denuded sone adjacent to gratn boundary.

F1gure 40. Microstructure of type 304 stalnless steel 1rradiated at $390^{\circ} \mathrm{C}$ tc $7.6 \times 10^{21}$ neutrons $/ \mathrm{cm}^{2}(\mathrm{z}>0.1 \mathrm{MeV})$.

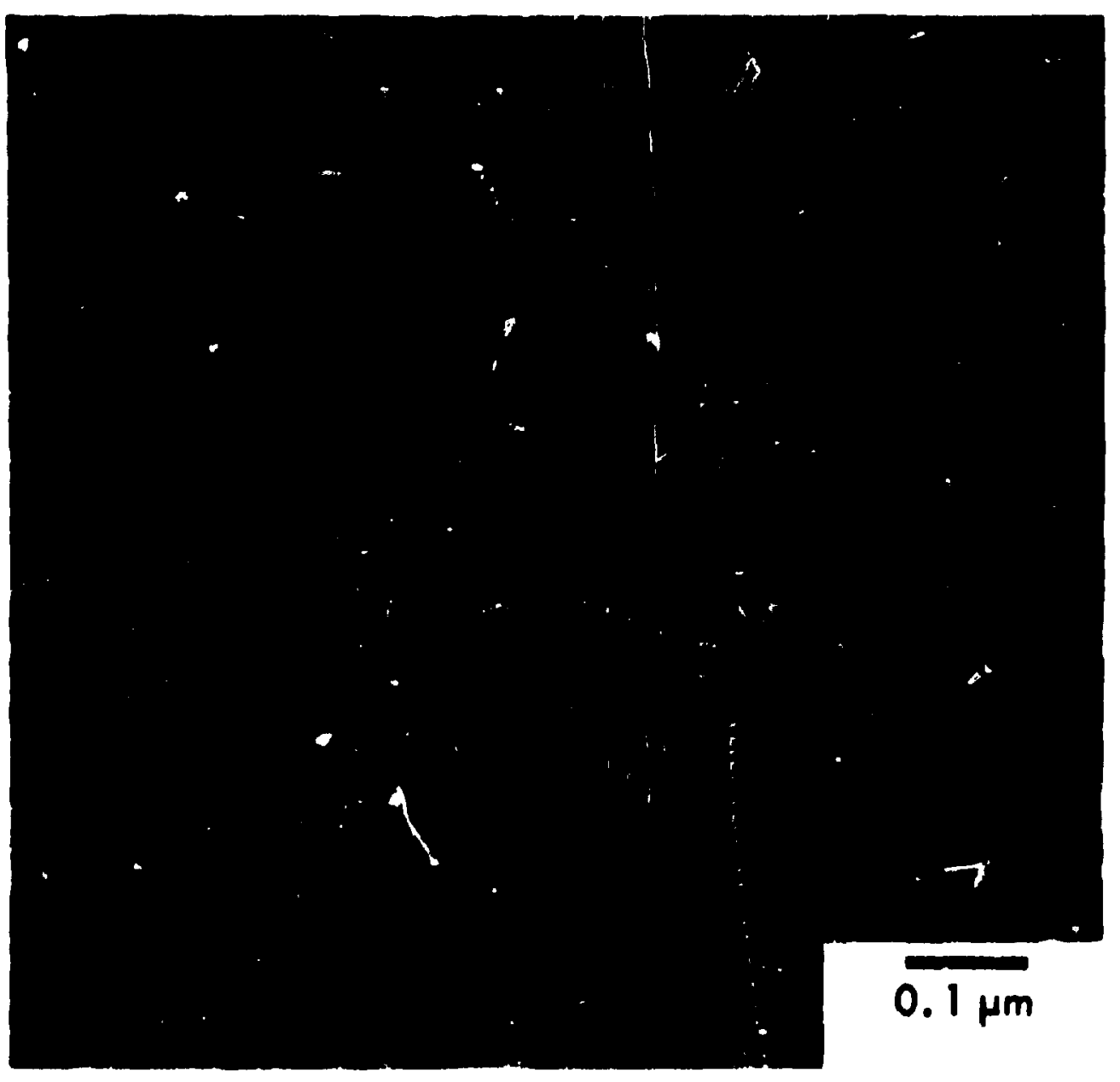

(b) Dislocation 10ops. Note region adjacent to grain boundary which 18 denuded of loops. 
boundaries with intense loop formation at the boundaries have been reported by stiegler and Bloom (53).

The void and loop structure in the specimen which contained $20 \times$

$10^{-6}$ atom fraction helium prior to irradiation is shown in Figure 47. The microstructure is in general mach finer than that of the specimen which contained no helium. The aximun vcid diameter was approximately $60 \mathrm{~A}$ and the concentration of visible voids was $5.2 \times 10^{15}$ voids $\mathrm{cm}^{3}$. Because of the very saall void sizes, it is probable that a large fraction of the total void population probably was not resolved, and thus, the actual void concentration be significantly higher. The zone adjacent to grain boundaries which was denuded of voids was only $10 i j-200$ A wide and loop formation occurred up to the grain boundary. Comarison of Figure $46 \mathrm{~b}$ and Figure $4 \mathrm{~Tb}$ also indicates that the loop diameters were smaller and the concentration higher in the specimen which contained helium prior to irradiation.

\section{TMRERSION DENSITY MEASUREMENTS}

Results of inmersion density measurements on specimens removed from the EBR-II safety rod thimble are listed in Table $V$. The density change was calculated by compari:3on with the density of spectmens removed from the very ends of the thimble where TEM examination showed essentially no vold formation. The reported values are the average of five independent measurements. These density decreases are plotted in Figure 48 as a function of the position of the specimen in the reactor during irradiation. The curve is nearly symetrical but is displaced 

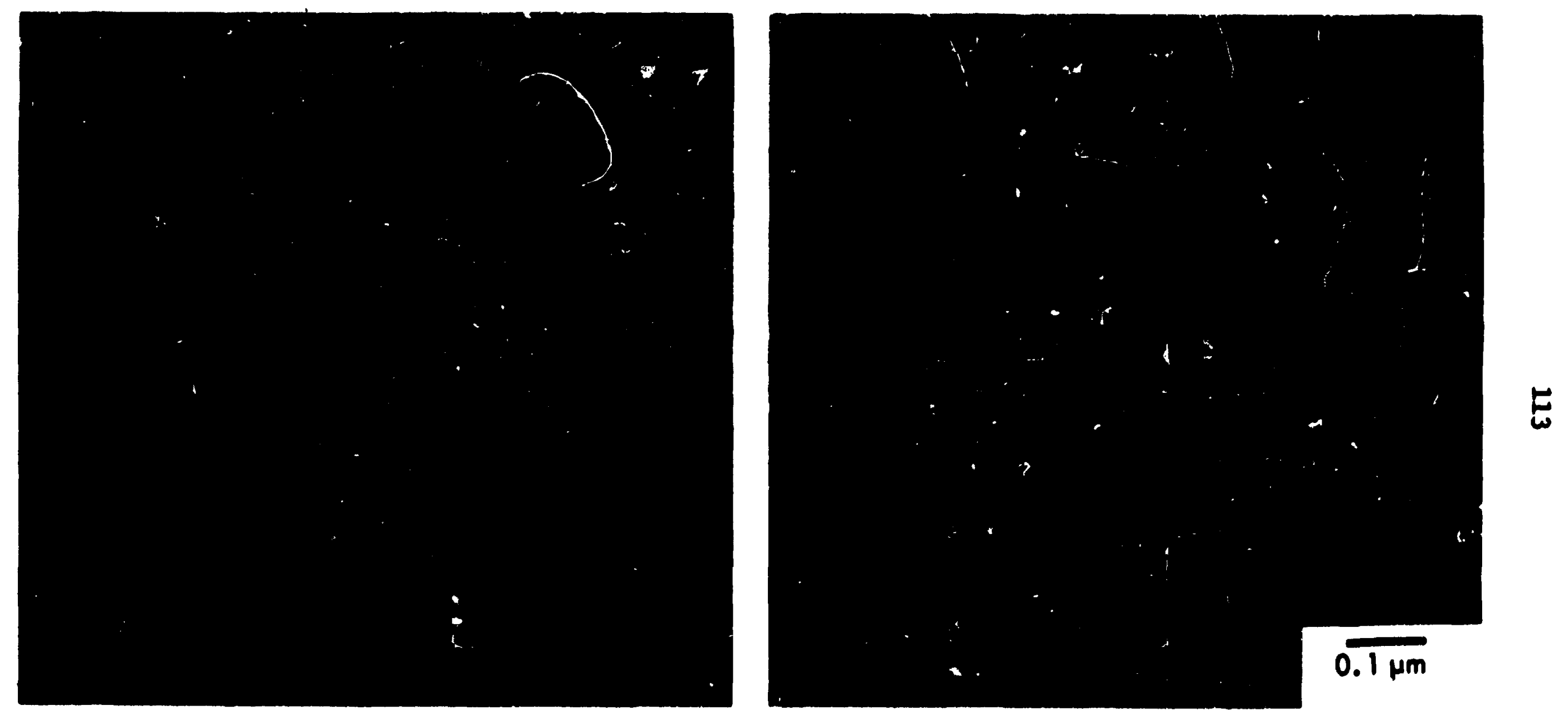

(a) Volde.

(b) D1slocation structure.

F1gure 47. Merostructure of type 304 stainlese steei which contafned $20 \times 10^{-6}$ atom fraction helium prior to 1 rradiation at $390^{\circ} \mathrm{C}$ to $7.6 \times 10^{21}$ nautrons $/ \mathrm{cm}^{2}(\mathrm{E}>0.1 \mathrm{MoV})$. 
TAIJLE V

DENSI'IY CHANGE OF SPECIMENS REMOVED FROM THE EBR-II SAFETY ROD THIMBLE

\begin{tabular}{|c|c|c|c|c|c|}
\hline $\begin{array}{c}\text { Irradiation } \\
\text { Temperature } \\
{ }^{\circ} \mathrm{C}\end{array}$ & $\begin{array}{l}\text { Neutrons } / \mathrm{cm}^{2} \\
E>0.01 \mathrm{MeV}\end{array}$ & $\begin{array}{c}\text { Denolty of Irradiated } \\
\text { Speclmen } 8 \mathrm{~m} / \mathrm{cm}^{3} \\
\rho_{I}\end{array}$ & $\begin{array}{c}\text { Standard } \\
\text { Deviation of } \\
\rho_{I}\end{array}$ & $\begin{array}{l}\text { Densfty } \\
\text { Decrease } \\
\frac{\Delta \rho}{\rho_{0}}(\%)\end{array}$ & $\begin{array}{l}\text { Standard } \\
\text { Deviation } \\
\frac{\Delta p}{\rho_{0}}(x)\end{array}$ \\
\hline $\begin{array}{l}370 \\
370 \\
370 \\
370 \\
370 \\
374 \\
381 \\
393 \\
410 \\
421 \\
432 \\
444 \\
455 \\
462 \\
462 \\
462 \\
462 \\
462\end{array}$ & $\begin{array}{l}3.7 \times 10^{21} \\
5.8 \times 10^{21} \\
9.2 \times 10^{21} \\
1.4 \times 10^{22} \\
3.1 \times 10^{22} \\
4.3 \times 10^{22} \\
5.8 \times 10^{22} \\
5.6 \times 10^{22} \\
6.5 \times 10^{22} \\
5.5 \times 10^{22} \\
4.2 \times 10^{22} \\
2.9 \times 10^{22} \\
2.1 \times 10^{22} \\
1.3 \times 10^{22} \\
9.2 \times 10^{21} \\
5.8 \times 10^{21} \\
3.6 \times 10^{21} \\
2.0 \times 10^{2.1}\end{array}$ & $\begin{array}{l}7.8818 \\
7.8800 \\
7.8673 \\
7.8621 \\
7.8542 \\
7.8399 \\
7.7901 \\
7.7033 \\
7.6349 \\
7.6609 \\
7.7823 \\
7.8282 \\
7.8580 \\
7.8611 \\
7.8748 \\
7.8796 \\
7.8861 \\
7.8867\end{array}$ & $\begin{array}{l}.0214 \\
.0166 \\
.0131 \\
.0160 \\
.0060 \\
.0168 \\
.0766 \\
.0110 \\
.0064 \\
.0214 \\
.0099 \\
.0059 \\
.0115 \\
.0199 \\
.0267 \\
.0219 \\
.0168 \\
.0040\end{array}$ & $\begin{array}{l}0.07 \\
0.10 \\
0.26 \\
0.32 \\
0.42 \\
0.60 \\
1.23 \\
2.34 \\
3.20 \\
2.49 \\
1.33 \\
0.75 \\
0.37 \\
0.34 \\
0.16 \\
0.10 \\
0.02 \\
0.01\end{array}$ & $\begin{array}{l}0.02 \\
0.01 \\
0.02 \\
0.03 \\
0.01 \\
0.04 \\
0.30 \\
0.05 \\
0.04 \\
0.12 \\
0.04 \\
0.01 \\
0.02 \\
0.04 \\
0.03 \\
0.02 \\
<0.01 \\
<0.01\end{array}$ \\
\hline
\end{tabular}




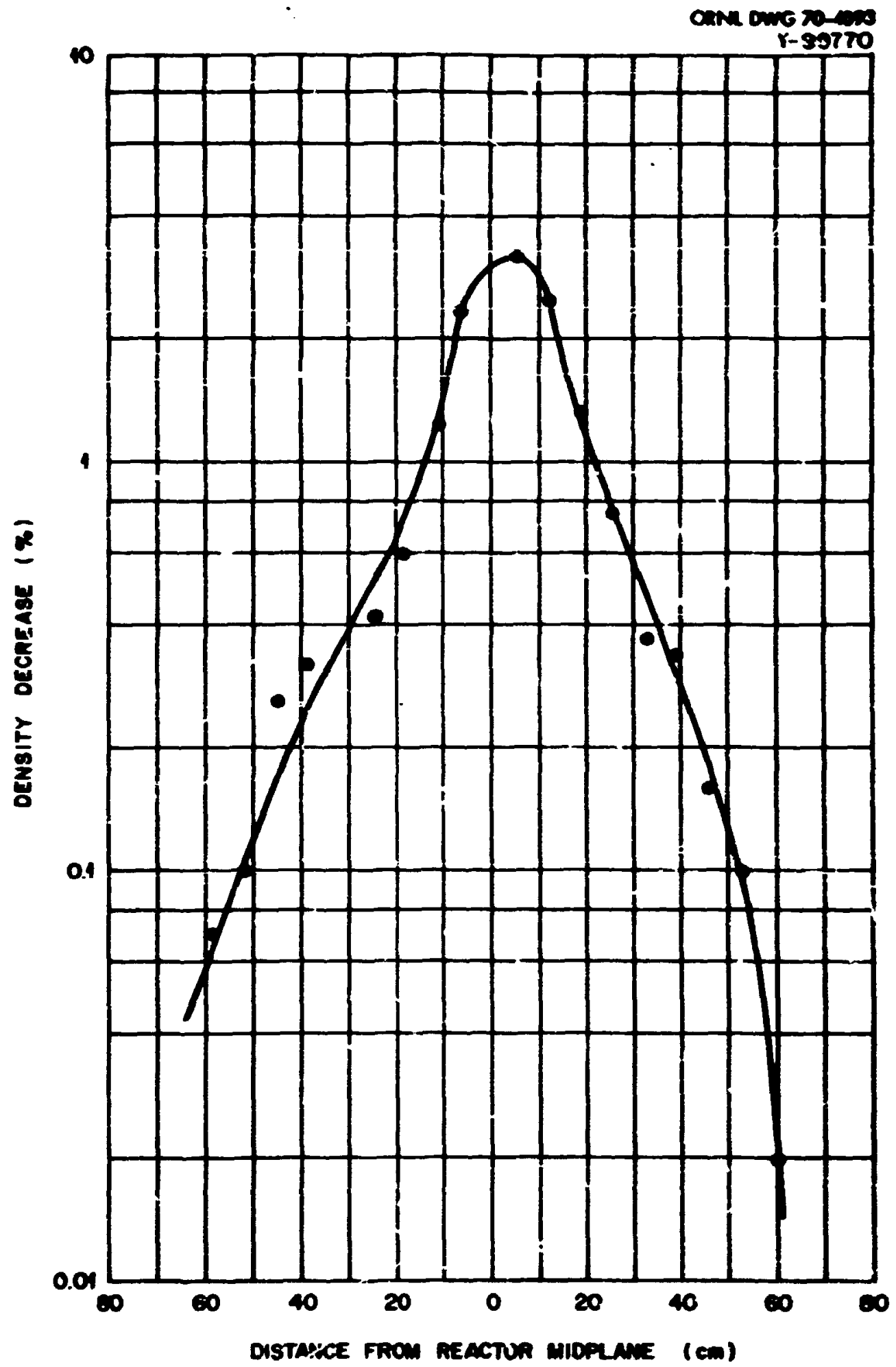

Figure 48. Density decrease as furction of axial distance from reactor midplane for $B B R-I I$ safety rod thimble. 
to a position slightiy above the reactor midplane. This displacenent is due to the fact that the swelling is both fluence and temperature dependent. The swelling increases with increasing fluence (at constant temperature) or with increasing temperature (over the range $370-470^{\circ} \mathrm{C}$ ) at conetant fluence. Since the temperature fincreases from the bottom to the top of the reactor and the neutron flux peaks at approxinately the reactor midplane, the maxinu swelling occurs slightly above the midplane.

The density changes in type 304 and type $304 \mathrm{~L}$ stainless steels Irradiated at $570-630$ and $770-840^{\circ} \mathrm{C}$ to $3.7 \times 10^{22}$ neutrons $/ \mathrm{cm}^{2}$ (E > C.1 MeV) are liated in Table VI.

The density decrease as a function of fluence detormined by inmersion measurements and calculated from the vold concentration and size distribution is shown in Pigures 49 and 50 for irradiation temperatures of $370-380$ and $460-470^{\circ} \mathrm{C}$, respectively. At each temperature, the density decreases measured by the two different techniques are in reasonably good agreement. Data for these two irradiation temperatures were used to determine the fluence dependency $x$, of the density decrease in an expression of the form

$$
\frac{\Delta p}{\phi} \propto(\phi t)^{X} .
$$

The values of $X$ as determined by a least square fit of the data were 0.84 and 1.60 for irradiation temperatures of $370-380$ and $460-470^{\circ} \mathrm{C}$, respectively. These values for the fluence dependency of the density decrease are consistent with the fluence dependency of the vold concentration as given in Figure 42, page 104. It thus appears that the 
TABLE VI

DENSITY AND DENSITY CHANGE IN TYPE 304 STAINLESS STEEL IRRADIATED ${ }^{2}$ IN EBR-II EXPERIMENTAL SUBASSEMBLY X0-34

\begin{tabular}{|c|c|c|c|c|c|}
\hline Macerlal & $\begin{array}{l}\text { Irradiation } \\
\text { Temperature } \\
{ }^{\circ} \mathrm{C}\end{array}$ & $\begin{array}{c}\text { Denelty of Irradiated } \\
\text { Specimen } 8 \mathrm{~m} / \mathrm{cm}^{3} \\
\rho_{I}\end{array}$ & $\begin{array}{c}\text { Standard } \\
\text { Deviation of } \\
\rho_{I}\end{array}$ & $\begin{array}{l}\text { Density } \\
\text { Decrease } \\
\frac{\Delta \rho}{\rho_{0}}(\%)\end{array}$ & $\begin{array}{c}\text { Standard } \\
\text { Deviation of } \\
\frac{\Delta \rho}{\rho_{0}}(z) \\
\end{array}$ \\
\hline $\begin{array}{l}304 \\
\text { Stainles8 } \\
\text { Steelb }\end{array}$ & $\begin{array}{l}570-630 \\
770-840 \\
770-840\end{array}$ & $\begin{array}{l}7.8758 \\
7.8905 \\
7.8916\end{array}$ & $\begin{array}{l}0.0027 \\
0.0026 \\
0.0041\end{array}$ & $\begin{array}{r}0.19 \\
0.01 \\
-0.01\end{array}$ & $\begin{array}{l}<0.01 \\
<0.01 \\
\end{array}$ \\
\hline $\begin{array}{l}304 \mathrm{~L} \\
\text { Stainless } \\
\text { Steel }\end{array}$ & $\begin{array}{l}570-630 \\
570-630\end{array}$ & $\begin{array}{l}7.8674 \\
7.8663\end{array}$ & $\begin{array}{l}0.0037 \\
0.0038\end{array}$ & $\begin{array}{l}0.06 \\
0.07\end{array}$ & $\begin{array}{l}<0.01 \\
<0.01\end{array}$ \\
\hline
\end{tabular}

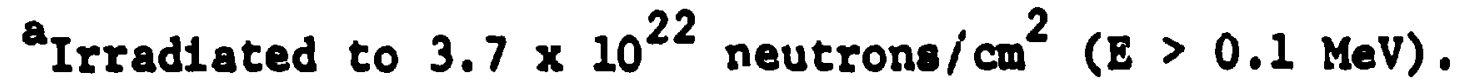

butrradiated density $7.8911 \mathrm{gm} / \mathrm{cm}^{3}$.

Untrradiated density $7.8724 \mathrm{gm} / \mathrm{cm}^{3}$. 


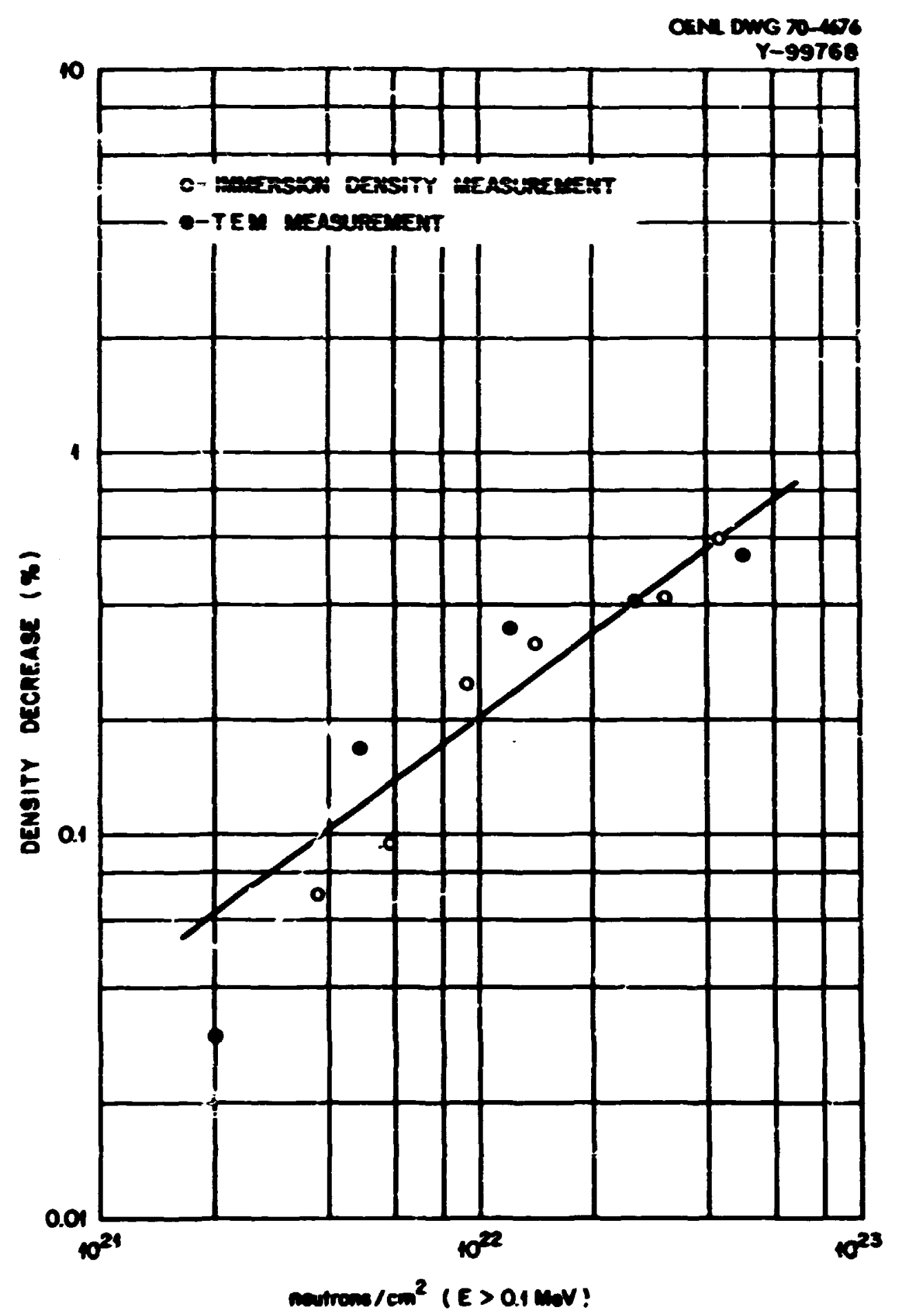

P1gure 19. Density decrease versus fluence for type 304 stain1 ess steel Irradiated at $370-380^{\circ} \mathrm{C}$. 


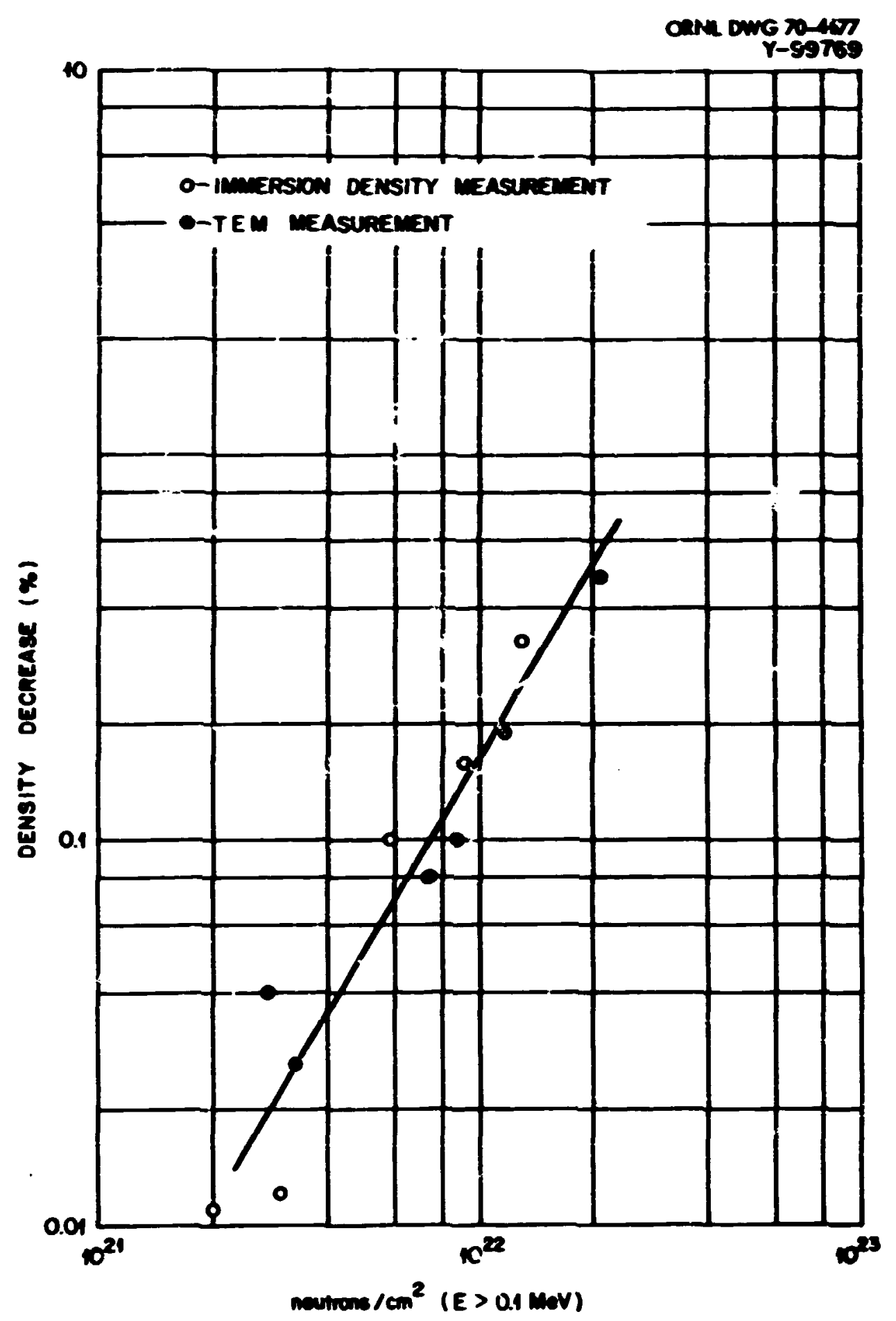

Figure 50. Density decrease versus fluence for type 304 stainless steel Irradiated at $460-470^{\circ} \mathrm{C}$. 
fluence dependency of swelling is not temperature independent as was assumed in the analysis of Claudson et al. (52).

The density change as a function of irradiation temperature was examined by normalizing the data listed in Tables $\nabla$ and VI, pages 113 and 116 , to a fast neutron fluence of $4.0 \times 10^{22}$ neutrons $/ \mathrm{cm}^{2}$ (E > $0.1 \mathrm{MeV})$. This fluence was used because it is approxinately equal to the fluence accumulated by the specinens irradiated at $570-630^{\circ} \mathrm{C}$. Because of the linited data and the uncertainties in the fluence dependency at temperatures other than $370-380$ and $460-470^{\circ} \mathrm{C}$ the data were zormalized to the desired fluence using an assumed fluence dependency of 1. The results, shown in Figure 51, 11lustrate the strong temperature dependency of the density decrease. 


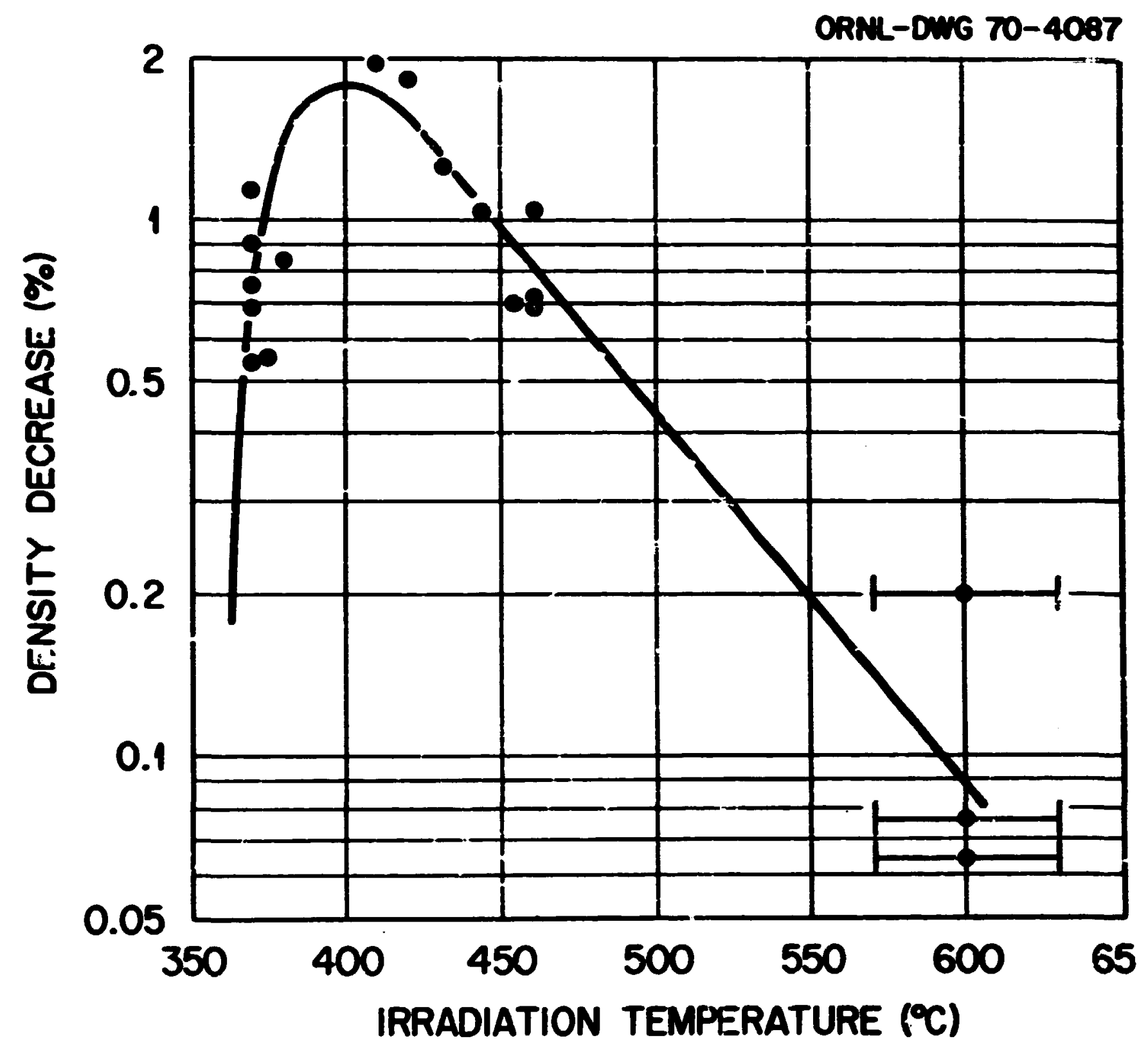

Figure 51. Density decrease versus temperature.

Data are normalized to a fluence of $4 \times 10^{22}$ neutrons $/ \mathrm{cm}^{2}$ $(E>0.1 \mathrm{MeV})$ using $\Delta \rho / \rho \propto(\phi t)^{1.0}$. 
Changes in the microstructure of type 304 stainless steel as a result of fast neutron 1rradiation at temperatures between 370 and $840^{\circ} \mathrm{C}$ to fast neutron fluences to $7 \times 10^{22}$ neutrons $/ \mathrm{cm}^{2}$ ( $\mathrm{E}>0.1 \mathrm{HeV}$ ) have been foilowed by transission electron aicroscopy. The naterials were Irradiated in the BBR-II efther as reactor components or as specimens contained in reactor subasse-blies spectfically designed for naterials Irradiation experiments. The results of the investigation are sumarized and discussed below.

Irradiation Damage at Low Fluences

Ho danage was observed at the lowest fluence at which specinens were examined $\left[1.1 \times 10^{18}\right.$ neutrons $\left./ \mathrm{cm}^{2}(\mathrm{~B}>0.1 \mathrm{MeV})\right]$. After irradiation to $1.4 \times 10^{20}$ neutrons $/ \mathrm{cm}^{2}(\mathrm{~B}>0.1 \mathrm{MeV})$ small defect clubters which appeared as black dots when examined under diffraction contrast conditione (F1gures 17 and 22, pages 55 and 73) were present. Diffraction contrast from these defects was consistent with that expected from three defect types: (1) dislocation 100ps having an a/3 (i11) Burgers' vector, (2) dislocation 100 p having an a/2 (110) Burgers' vector and (3) a spherical or three dimensional cluster rather than a planer defect such as a loop. In excess of $75 \%$ of the defects were dislocation loops having an a/3 (111) Burgers' vector. Stiegler (70) has analyzed the 
ccrissst arlsing from these $100 p$ and has concluded that the: are nosty Interstitial in nature. The three dinensional defects are assuned to be vacancy clusters. As the irradiation tepperature was increased from 384 to $496^{\circ} \mathrm{C}$, the defect cluster concentration decreased contimously. After irradiation to $1.4 \times 10^{20}$ neutrons $/ \mathrm{cm}^{2}(\mathrm{E}>0.1 \mathrm{HeV})$ at $524^{\circ} \mathrm{C}$ no clusters were observed. This observation indicates that there is an Incubation pertod before defect clusters begin to form or that the initial gxouth rate is very slow since damage is observed at fiuences sbove $1.4 \times 10^{20}$ neutrons $/ \mathrm{cm}^{2}$ (B $1 \mathrm{HeV}$ ) at temperatures above $500^{\circ} \mathrm{C}$. Hote, however, that because of the sall volunes which are exanined and the resolution of the aicroscope, approxinately $10^{12}$ defects larger than about $15 \mathrm{~A}$ dianeter would have to be present in order to be detected.

\section{Developent of Dislocation Structure}

As the fast neutron fluence was increased above $1.4 \times 10^{20}$ neutronsi ${ }^{2}$ ( $\mathrm{E}>0.1 \mathrm{HeV}$ ) the dislocation lovg concentration continued to increase and the $100 p 8$ continued to grow. On the basis of fiualitative obsexvations, it appeared that for a constant fluence the loop concentration decreased and the loop dianeter increased the greater the Irradiaticn temperature in the range 370 to $470^{\circ} \mathrm{C}$ (Figures 21 and 25, pages 71 and 78). The appearance of the dislocation loops under various diffraction conditions was consistent with that of interstitial dislocation loops having a/3 (111) Burgers' vector. This type of dislocation is sessile and bounds a stacking fault. At low neutron fluences, before the loop structure became too dense and couplex for observation of the 
individual loops, several different loop forms or shapes were present. The loop distribution was affected by the presence of structural irregularities, such ss dislocations and grain boundaries.

After irrad 2 tion at $370^{\circ} \mathrm{C}$ to relatively 1 ow fluences, the clustering of dislocation loops about dislocation lines (Figure 20, page 70) was evident. This olservation of clustering has been reported by Plercy and Whitton (76) and Stiegler et al. (13), for loops in irradiated aluninum and aluinum alloys. Plercy and Whitton attributed the clustering In deforned areas of the sample to the irradiation-induced vacancies enlarging subetcroscoplc vacancy loops produced by deforeation prior to Irradiation. This mechanisa is unlikely to be operative in the case of stainless steel since the loops are interstitial instead of vacancy in character. However, dislocations alght influence loop nucleation as a result of the segregation of impurities in the vicin'ty of the dislocacton. Segregation of large atons to the tension side of a dislocation and enall atoms to the compression side was initially proposed by Cottrell and Bilby (77). Local variations in composition might reduce the stacking fault energy, making nucleation easier in such reglons. Stiegler and Bloom (53) have reporled that the loop distribution near grain boundaries in type 30\% stainless steel was dependent upon the irraziation temperature. A specimen irradiated at $372^{\circ} \mathrm{C}$ to $0.8 \times 10^{22}$ neutrons $/ \mathrm{cm}^{2}$ (E > $0.1 \mathrm{KeV}$ ) had a grain boundary zone between 750 and 1500 A wide which was deunded of the loop structure whereas heav loop formation occurred immediately adjacent to the boundary. For irradiation at $472^{\circ} \mathrm{C}$ the denuded zone was not observed and loops formed up to a 
grain boundary. Exanination of the grain boundaries revealed that at $372^{\circ} \mathrm{C}$ no grain boundary precipitate vas visible, whereas at $472^{\circ} \mathrm{C}$ precipitates about 1000 A in dianeter were present.

It thus appears that solute or Impurity atom can play a role in interstitial loop nucleation. For stainless steel carbon is probsbly the responsible element. In the case of specimens irradiated at $372^{\circ} \mathrm{C}$, carbon could be segregated to the boundary, giving a locally high concentration at the boundary, a sone depleted is carbon indediately adjar cent to the boundary, and the nominal concentration at regions still further resoved from the boundary. Sinilar $y$ in specimens containing dislocations it is likely that carbon had segregated to the dislocations. In both cases loop formatiou was enhanced in reglons containing excess carbon and in the case of grain boundarles, loop formation was depressed in the sone depleted of carbon. In contrast, when carbon segregates to the boundary and forms carbide prectpitates, such as at $472^{\circ} \mathrm{C}, 100 \mathrm{p}$ formation is not affected.

Also observed at an Irradiation temperature of $460-470^{\circ} \mathrm{C}$ were gall rod-shaped precipitates on dislocations which were present in the material prior to irradiation (FIgure 23, page 74). These precipitate were quite unffornly spaced along the dislocation and nearly always occurred on the same side of the dislocation line. Sinilar structures have been observed by Beckitt and Clark (72) in an austentic stainleas steel which had been solution treated and aged for short periods of time at $700^{\circ} \mathrm{C}$. The precipitates were about the sane size and were uniformly spaced along the dislocsitons. Although not specifically 
mentioned by Beckitt and Clark, some of thejr photonicrographs also suggest that the precipitates initially ford on one side of the dislocation. These investigators identified the precipitates as $\mathrm{M}_{23} \mathrm{C}_{6}$ type carbides. On the basis of the sinilar norphricgies one nay concluie that the precipitates observed in this investigation ay also be $\mathrm{M}_{23} \mathrm{C}_{6}$ type carbides. The occurrence of the precipitates on only one side of a dislocation way be a result cf the stres; field of the dislocation. There was sowe evidence that the growth of the precipitates was influenced by the fast neutron flux and/or fluence. For exaple, the precipitates were significantly larger in a specinen irradiated at a higher flux to a higher fluence but at the same temperature.

As the fast neutron fluence was increased for irradiation temeratures between 370 and $470^{\circ} \mathrm{C}$ the inhomogenities in dislocation loop distributions, irregularly shaped loop structures and dislocation Iine-precipitate structures becane progressively wore difficult to observe due to the increase in density and size of the more regular, faulted, interstitial dislocation loops.

There was a marked change in dislocation structure for specinens irradiated at $570-630^{\circ} \mathrm{C}$ as compared to $470^{\circ} \mathrm{C}$. The faulted dislocation lcops present at the lower temperature were replaced by a network of dislocation lines and a few unfaulted dislocation loops (Figure 29, page 85). The possible reasons for this change in dislocation structure with increasing irradiation temperature can be discussed in terms of the energles associated with faulted and perfect dislocation loops with Burgers' vecturs of $a / 3\langle 11\rangle$ and $a / 2\langle 110\rangle$, respectively. These 
energies vere given in Equations 11 and 12 which represent the elastic strain energy of the dislocation plus the energy assoctated with the stacking fault, if one is present. Using these equations, Friedel (78) shows that in wetals having stacking fault energies $Y$ such that

$$
Y>\frac{G b}{30}
$$

perfect or unfaulted loops are the lower energy configuration for all loop sizes. For wetals with low stacking fault energy where Bquation 38 is not fulfilled, faulted loops are the not statle for sall loop sizes. However, as a faulted loop grows the energy of the stacking fault increases as the square of the loop radius, $\left(B_{l}\right)^{2}$, and the energs of the dislocatf.cn line increases as $\mathrm{B}_{\ell}$. Thus, there is a ioop radive such that for larger radil the perfect dislocation loop is wre stable and for snaller radil the faulted loop 18 wore stable. The loop radius at which this transition occurs is a function of the stacking fault enerso. Indirect evidence (79) obtained frow a study of deformation snd recrystallization textures indicates that austenitic stainless steels behave as if the stacking fault energy increnses as tenerature increases. If the stacking fault energy exceeds the right hand side of Equation 38 the Interstitials should precipitate in perfect or unfaulted 10ope since this would be the lower energy configuration. Alternately, if the atackIng fault energy is lower than that given by the right hand side of Bquation 38, then the Interstitials should inftially precipitate to form faulted 100pa. As these faulted loops grow two factors tend to aske the perfect loop the lower energs configuration. With increaning Irradiation 
temperature the loop concentration decreases and the loops grou to larger sizes and with increasing irradiation temerature the stacking fault energy increases thus increasing the energy of a faulted 1oop. Figure 52 shows the energy of perfect dislocation loops and of faulted dislocation loops as a function of the loop radius calculated from Equations 11 and 12 . In the case of faulted dislocation loops stacking fault energies of $20 \mathrm{ergs} / \mathrm{cm}^{2}$, which is a typical value for stainless steel at 100 temperatures (80), and a higher value of 100 ergs/ $\mathrm{cm}^{2}$ were used. For each of these stacking fault energies there is a 100p radius above which the perfect loop is the wre stahle. This radius decre: with insreasing stacking fault energy. Thus if the loops are Initially faulted their growth will result in the perfect loop eventually becouing the lower energy configuration. The elfination of the stacking fault and conversion of a faulted dislocation loop to a perfect dislocation loop requires the nucleation of two Shockley partial dislocations. The dislocation reaction for the unfaulting of an a/3 [111] loop can be writen:

$$
a / 3[111]+a / 6[\overline{1} \overline{1} \overline{1}]+a / 6[\overline{2} \overline{1} \overline{1}]+a / 2[110]
$$

Since the strain energy of a dislocation is proportional to the square of the Burgers' vector this reaction is energetically favorable (1.e., the left side of Equation 39 is proportionsl to $2 / 3 \mathrm{a}^{2}$ and the right side 18 proportional to $1 / 2 a^{2}$.

Ipohorsk1 and Spring (81) have observer the unfaulting of Interstitial Erank loops in copper. The loops were produced in the electrow 


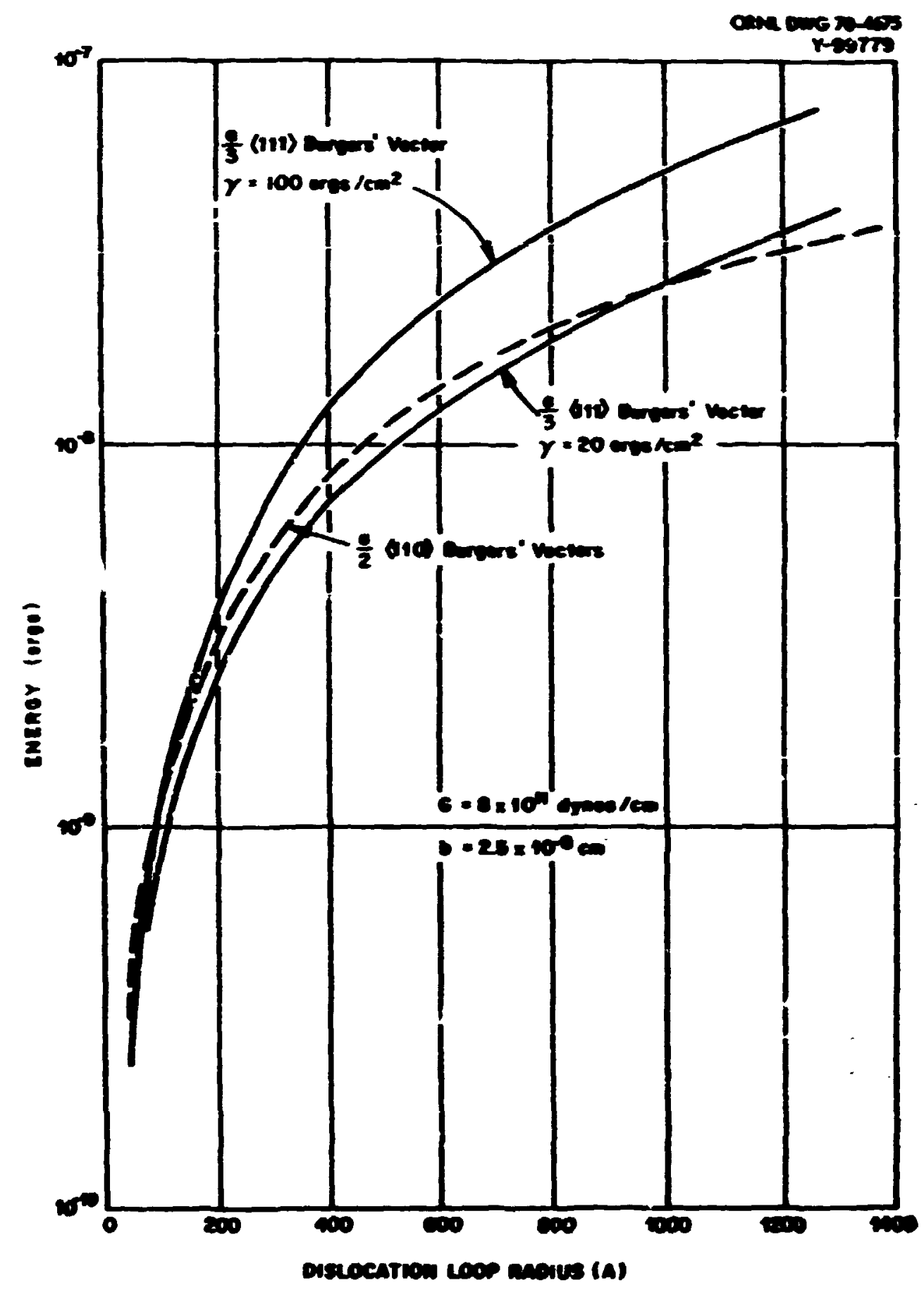

Pigure 52. Bnergs of $a / 3$ (11) and a/2 (110) dislocation loope a a function of $100 p$ radius. 
nicroscope by the electron displacement danage. No details of the unfaulting pechanism were given, however.

\section{Developent of Void Structure}

Voids, ranging in size fron the saallest observable in the electron microscope (approximately 50 A diameter) to several hundred angstroms diaseter were observed at irradiation temperatures between 370 and $570-600^{\circ} \mathrm{C}$. In this report, the tern void has been used to describe a cavity which has an Internal gas pressure significantly less than that required to balance the surface tension. In contrast, a bubble is a cavity containing a gas whose pressure balances or nearly baiances the surface tension.

The characteristics of the poid structure were studied as a function of fast neutron fluence and irradiation teaperature through observations of the vold distributions within the naterial, changes in vold shapes, and through measurement of vold concentration, volit size distributions, and changes in the density of the material.

Several qualitative observations concerning the frradiation produced voids had been reported previously and were confirmed during the course of this investigation. Volds did not form on grain boundaries nor in a region a few hundred angstrons wide on either side of the boundary $(1,2,52,53,54)$. In general the vold volume was orders of magnitude larger than that which could be stabilized by the irradiation produced helium $(1,2,52,53,54)$. For example, the specimen shown in Pigure 37, page 96, had a void concentration of $7.7 \times 10^{15} \mathrm{volds} / \mathrm{cm}^{3}$ (see Appendix F). The mean vold diameter was about 150 A. Assuming 
an Ideal gas, the number of gas atoms $\left(M_{0}\right)$ contained within a cavity having an equilibrium internai pressure is given by

$$
H_{0}=\frac{8 \pi Y R_{v}^{2}}{3 k T}
$$

Osing $R_{v}=1.5 \times 10^{-6} \mathrm{~cm}, Y=1500 \mathrm{ergs} / \mathrm{cm}^{2}$, and $T=700^{\circ} \mathrm{K}$, each void would require $3 \times 10^{5}$ gas at.oms to be at equilibriun. For the total vold concentration, about $2.2 \times 10^{21}$ tellim atoms $/ \mathrm{cn}^{3}$ would be required. The measured helium concentration for this specimen was $12.2 \times 10^{-6}$ atom fraction (82) or about $10^{18}$ helium atoms/ $\mathrm{cm}^{3}$, Esre than three orders of magnitude lesa than that required for eash cavity to contain an equilibriun amount. Previously reported experiments on BBR-II driver fuel cladding (53) have shown that the volds are unstable and can be renoved by postirradiation annealing at sufficiently high temeratures.

A number of results from this investigation elther have not been reported previously or are in substantfal disagreenent with previous results.

Claudson et al. (52) and Stiegler and Bloon (53) have characterIzed voids in stainless steel as being uniformly distributed. In each case the conclusion was based on examination of specimens irradiated to fluences in excess of $1 \times 10^{22}$ neutrons $/ \mathrm{cm}^{2}$ (E $>0.1 \mathrm{MeV}$ ). In this study spectwens Irradiated to lower flvences in the temperature range of $370-470^{\circ} \mathrm{C}$ contained a nonrandom, nonunfform distribution of volds There was a strong tendency for the volds to be located on structural. Irregularities such as dislocations. At higher fluences (within this 
temperature range), the vold density was wch greater and nonuniformities In the void distributions became nore difficult to detect. In the specimens Irradiated to $3.7 \times 10^{22}$ neutrons $/ \mathrm{cm}^{2}$ (E $>0.1 \mathrm{MeV}$ ) at $570-630^{\circ} \mathrm{C}$ the void concentration yas iow and rearly all voids were associatei sith dislocation lines. Nonuniform vold distributions have now been observed In several other irradiated materials: al.uminum by Stiegler et al. (13), nickel by Stiegler and Bloom (46), Iron by Farrell and Foueton (83), vanadium by Wiffen and Stiegler (84). Nonuniform distributions have important implications concerning the mechanism of void nucleation. Classical homogeneous nucleation, nucleation in single displacement spikes and nucleation by miltiple spike overlap would each lead to a random voli distribution. The apparent uniform rold distribution at neutron fluences exceeding approxdmately $1 \times 10^{22}$ neutrons/cn ${ }^{2}(E>0.1$ MeV) at temperatures between 370 and $470^{\circ} \mathrm{C}$ mey be real, implying that other nucleation mechanisms become operative (1.e., mechanisms which would produce uniform distributions), or that the increased void density simply obscures the heterogeneous nature of the distribution. To the author's knowledge the homogenity of the vold distributions at high fast neutron fluences has not been established. At temperatures near $600^{\circ} \mathrm{C}$, even at high fluences, the volds were always associated with structural irregularities.

Vold concentration as a function of fluence for irradiation temperatures of $370-380$ and $460-470^{\circ} \mathrm{C}$ and as a function of temperature fcr various fluences were 11lustrated In FIgures 42 and 43 , respectiveiy, pages 104 and 106. In specimens irradiated to a constant fluence, the 
vold concentration decreased with increasing irradiation teaperature. This latter result disagrees with data of Claudson et al. (\$2), which was reported to show that the void concentration was independent of Irradiation temperature in the range 370 to $470^{\circ} \mathrm{C}$. The results of Claudson et al. were not internally consistent since the density decrease varies by only a small amount between these two irradiation temperatures, yet the volds were significantly larger at the higher irradiation temperature. 'this requires the void concentration to be lower.

Over the range of fluences for which data were obtained, the vold concentration was higher after irradiation at $370-380^{\circ} \mathrm{C}$ than after Irradiation at $460-470^{\circ} \mathrm{C}$, jut was Increasing with fivence at a slower rate at the lower terperature. In order for this situetion to exist there must have been a transient or incubation period before significant void nucleation started. The length of this incubation perioc must have Increased with increasing irsadiation temperaturee. This conclusion is supported by the fact that no danage was observed after irradiation at $524^{\circ} \mathrm{C}$ to $1.4 \times 10^{22}$ neutrons $/ \mathrm{Cm}^{2}$ ( $\mathrm{B}>0.1 \mathrm{HeV}$ ) but voids and loops were observed after a fluence of $3.7 \times 10^{22}$ neutrons/ $\mathrm{cm}^{2}(\mathrm{E}>0.1 \mathrm{KeV})$ at the higher temperature of $570-630^{\circ} \mathrm{C}$.

Seversl. specimens were examined after Irradiation to approximately the sane fluence but at fast nevtron fluxies which were iffferent by as much as a factor of six. Within the acciracy of the experinental determination, there was no effect of flux on the vuid concentration. The only evidence for an effect of the fast seutron flux upon the damage 
structure was found in a comparison of a specimen Irradiated in a flur of $1.9 \times 10^{15}$ neutrons/ $\mathrm{cm}^{2}-\sec$ to $1.4 \times 10^{20}$ natuzuns/cme ( $>0.1 \mathrm{MeV}$ ) with a spectmen Irrart:zeii in a neutron flux of approximately $4 \times 10^{13}$ neutrons/ $\mathrm{c}^{2}$-sec to a fluesce of $5 \times 10^{20}$ neutrons $/ \mathrm{cm}^{2}$. The specimen Irradiated in the higher flux contained defect clusters but the speciesn irradiated in the lower flux did not.

Bariy In ite life a vold apparently grows very rapldly, but after a relatively low neutron fluence (on the order of $5 \times 10^{21}$ neutrossicm 2 (E $>0.1 \mathrm{Kev}$ ), the growth rate ciecreases. This was demonstrated by veanurement of maximin vold dianeter as a function of the fast neutron fluence. These results (Figure 44, page 108)indicated that it $370-380^{\circ} \mathrm{C}$ volds of ine maximu size (approyimately 210 A dianeter) vere observed after Irradiation to approximately $1 \times 10^{22}$ neutrons/ca ${ }^{2}(E>0.1 \mathrm{MeV})$ and that this maximu size did not change even wien the neutron fiuence was increased to $5.0 \times 10^{22}$ neutrons $/ \mathrm{c}^{2}(\mathrm{E}>0.1 \mathrm{MeV})$. Sinilar conclusfons were made for an Irradiation temperature of $460-470^{\circ} \mathrm{C}$ where the data indicatad that the volds grow rapidly early in their life and that the grouth rate then slows narkedly. Linited data indicate that the maximu void size increases sharply with increasing irradiation temperature (Figure 45, page 110).

The conclusion that the volds grow rapidly early in their life, then almost stop growing, was supported by observations of the vold shapes. Stiegler and Bloon (53) reported that the volds produced by Irradiation to fluences near $1 \times 10^{22}$ neutrons $/ \mathrm{cm}^{2}(R>0.1 \mathrm{MeV})$ at temperature above approximately $400^{\circ} \mathrm{C}$ were of ten very irregular in 
shape. At lower temperatures the volds were too small for their shape to be accuratsiy deternined. For higher flinences the voids were nre reguiar in appearance, with the volds in a given grafn often having a cormon shape (PIgur:es 31 and 38, pages 88 and 97).

These observations on vold shapes can be rationalized by an argument sinilar to that used by Stiegler et al. (85) to explain the shape of creep cavities in tungsten. Voids grow by the diffusion of vacancies into then. Barly in the 1ifa of a vold, the vacancies are entering the vold so rapidly that surface diffusion canot anintain the equilibrtir poiyhederal shape and the volds are nearly opherical. Later fir the growth process experimental observation shoved that the fiux of vacancies inco the voids decreases and surface diffusion allows the vold to wre closely approach its equilibriun shape.

Good agreement was obtained between the density decresse measured by imersion techniques and the density decrease calculated from measurements of the vold concentration and the vold size distribution curves. The fluence dependence $(x)$ of the clinsity decrease ieternined by a least square fit of the data in Figures 49 and 50, pages 118 and 119, to Equation 37 was 0.84 and 1.66 for irraciation temeratures of $370-380$ and $460-470^{\circ} \mathrm{C}$, respectively. The variation of the density decrease with fluerre and temerature is not adequately expressed by the single equation (Equation 15) used by Claudson et al. (52).

Irradiation at $777-840^{\circ} \mathrm{C}$ to a fluence of $3.67 \times 10^{22}$ neutrons $/ \mathrm{cm}^{2}$ (E > $0.1 \mathrm{MeV}$ ) did not produce damage in the form of volds and loope. Hellum bubbles, foimed by the prectpitation of the hellum produced by 
$(n, \alpha)$ transmitation reactions were pizesent. These bubbles were iocated along grain boundaries as well as in the matrix. The fact that these cavities were present on grain boundaris was evidence that they contained a gas and were not volds since voids do not for at grain boundaries.

\section{DISCUSSIOA OF RESULIS: NUCLEATION AND} GrOWTH MECHANISYS

Several nechanisus of vold nucleation and growth during fast neutron irradiation have been proposed. The present experimental results will be cospared to the predictions of these models in an attent to establish which wechantse or mechanisms are operative.

There is continuous production and annihilation of both vacancies and interstitials during irradiation, and as a result, the concentration of these defects exceeds the thermal equilibrium concentration at any given instart. The vacancy concentration during irradiation $\left(C_{v}\right)$ is glven by

$$
C_{v}=x_{v 0}=\frac{\alpha \tau}{H},
$$

where

$$
\begin{aligned}
& c_{v}=\text { vacancy concentiation, } \\
& c_{v o}=\text { vacancy concentration at thermal equilibriu, } \\
& \varepsilon=\text { vacancy supersaturation ratio, } \\
& \alpha=\text { vacancy production rate (vacancies } \mathrm{c}^{-3} \mathrm{sec}^{-1} \text { ), } \\
& \tau=\text { averagu vacancy } 11 f e t i n \text { (sec), and } \\
& r=\text { lattice sites } \mathrm{cm}^{-3} .
\end{aligned}
$$


If the vacancy supersaturation during Irradiation is oufficiently large, then homgeneous nucleation of volds by randon fluctuation in the size of vacancy clusters aight occur.

The change in free energy $\left(\Delta G_{v}\right)$ when a vacancy is added to a vold (containing no gas) is given by:

$$
\Delta G_{V}=\frac{2 \eta \Omega}{R_{v}}-k T \ln \frac{C_{v}}{C_{v_{0}}}
$$

where

$$
\begin{aligned}
& R_{\nabla}=\text { vold radius, } \\
& \boldsymbol{\Omega}=\text { atonic volune, and } \\
& \gamma=\text { surface energy. }
\end{aligned}
$$

The critical vold radius, $R_{\nabla}^{*}$, at which size the free enersy change soes through a naximin, $\left(\Delta G_{v}=0\right)$, is related to the vacancy supereaturation $\left(C_{\nabla} / C_{v 0}\right)$ by

$$
R^{*}=\frac{2 \Omega}{k T \ln \frac{C_{v}}{C_{v 0}}}
$$

If the vacancy supersaturation is sufficiently large, vacancy clusters produced in the displacenent spikes will exceed the critical sise and a rold would be nucleated. The temperature, tine and flux dependence for such spike mucleation would not be the sane as for homgeneow nucleation. Spike nucleation will thus be discused separately. 
For vacancy superseturations at wich the critical void size is larger than the maximu cluster size produced in displacenent spikes, bowogeneous nucleation can occur. Under these conditions the nucleation rate, (I), as given by Turnbull and Fisher (86), will be

$$
\dot{I}=R C_{v} \exp \frac{15 \pi \sigma^{3}}{3\left(k T \ln \frac{C_{v}}{C_{v 0}}+\frac{2 \gamma \Omega}{R_{v}^{*}}\right)} \exp -\frac{\Delta G}{k T}
$$

were $R$ is a constant, $C_{v}$ is the vacancy concentration, the first exfonentizl is the concentration of nuclet of the critical size (see Equation 26), and the second exponential is the vacancy woblity, with $\Delta G$ beling the energy of vacingy notion.

It is difficult to relate the homgeneous nucleation rate to the Irradiation paraneters of neutron flux, Irradiation time and Irradiation temperature because of the complexty of the vacancy production and amihilation processes. For example, the vacancy concentration during Irradiation depends on the nubber of vacancies produced per PKA (prinary knock-on atom), the fraction of this total which are anaihilated almot imediately, and the fraction which diffuse through the lattice and are annihilated by recombinution, or absorption at stes such as grown in dislocations, grain boundaries, Irradiation-produced dielocation loops or Irradiation produced volds. Formulation of these quantities involves a large number of unknown paraneters.

There are several qualitative considerations which indicate that homogeneous nucleation of volds does not predontnate. In specinens 
Irradiated at the same temperature, to the sane total fluence, but at fluxes which differed by a factor of $81 x$, no difference in vold conceatration was observed. Increasing the neutron flux at constant terpereture should have increased $C_{v}(54,57)$, and thus, both the pre-exponential and exponential parts of Equation 44 would increase. Integration of this equation over the Irradiation time $\left(t_{1}\right.$ and $t_{2}$ for the spectens irradiated at fiuxes of $\phi_{1}$ and $\phi_{2}$, respectively, where $\phi_{1}=6 \phi_{2}$ and $\phi_{1} t_{1}=\phi_{2} t_{2}$ ) leads to a higher predicted vold concentration in the speciwen Irradiated at the higher flux. The data do not support this nodel.

Bonogeneous nucleation can not explain the heterogeneous vold distributions observed at 10 fluences nor can it explain the observetion that specimens containing heliu prior to irradiation had a larger soncentration of smaller volds than specinens which contained no injected hellu.

If the vacancy supersaturation during irradiation is sufficlenty large a portion of the vacancy clusters produced in the displacenent spikes are larger than the critical size and woid mucleation in the displacement apike occurs. Until the vold concentration begins to saturate, the nucleation rate should then be proportional to the flux and the vold concentration should Increase as $(\phi t)^{1.0}$. The present results show that the roid concentration Increases approxtately as $(\phi t)^{0.8}$ and $(\phi t)^{1.4}$ at temperatures of $370-380$ and $460-470^{\circ} \mathrm{C}$, respectively. At $370-380^{\circ} \mathrm{C}$ eaturation of the vold concentration has probably begun and the fluence dependence is less than unity. Bowever, at $460-470^{\circ} \mathrm{C}$ the fluence dependence of 1.4 1s wigher than that predicted by optke macleatlon. If vold 
nucleation did occur in displacenent spikes the presence of heliu should have no effect on the vold concentration and the vold distribution should be uniform. The predictions of this nodel do not fit the Diservations of the present work.

If a single displacenent spike cannot produce a vacancy cluster of the critical size, then possibly the overlapping of two or more spikes in a short period of tine could. This is essentially the codel proposed by Beeler (56). In this case, the nucleation rate would be proportional to $(\phi)^{x}$ where $x$ is the nuber of spike overlaps necessary to produce a nucleus of the critical size. The vold concentration after a given Irradiation tine would then be proportional to $\phi^{x_{t}}=\phi^{x-1}(\phi t)$. If this nechaniso is operative, the woid concentration after a given Irradiation would depend on the neutron flux in which the specinen was irradiated. Such flux dependence was not observed. As with hovogeneous and single spike nucleation, the void concentrations should be independent of the presence of hellu, and the volds should be homgeneously distributed contrary to the experimental observations.

Other nucleation nechanisins which have been suggested but which are not suppoited by the present experimental results include: nuclestion on sites which exist prior to irradiation; (2) the stabilization of displacement spikes by hellim produced by $(n, a)$ reactions and (3) the nucleation nodel proposed by Harkness and II (54). For mucleation on pre-exdsting sites the vold concentration would be expected to saturate early in the irradiation, Eowever, the vold cracentration continuousiy increases for fluences betreen $2 \times 10^{21}$ and 
$6 \times 10^{22}$ neutrons/ $/ \mathrm{cm}^{2}(\mathrm{~B}>0.1 \mathrm{keV})$. The stabilization of displacenent spikes by hellu atoms would lead to a nucleation rate dependeni on both the hellum concentration $\left(C_{\mathrm{Be}}\right)$ and the displacenent spike concentration. In general, a spectrun of vacancy cluster sizes vould be produced. The nuber of hellim atoms required to stabilize a given cluster would depend upon that particular cluster 612 (more helfum atoms the amaller the cluster). Since the hellum concentration varies approxdmtely as (\$t), and the concentration of displacentent spikes as $\phi$, the nucleation rate (if the clusters were all of the same size and if only one hellin aton per cluster were required) would be approxdately dependent on $\phi^{2} t$ and the vold concentration on $(\phi t)^{2}$, a higher power of the fluence than observed. In addition, this nechanisen should lead to a homogeneovs woid distribution which, as pointed out previously is not observed at low vold concentrations.

The Harkness and LI (54) nodel assunes that vold nucleation occurs in displacement spikes but has the temperature dependence of homgeneovs nuclistion. The wodel contains a mber of paraneters wich are adjusted by fitting the wodel to the total density change which occurs during Irradiation due to both vold pucleation and woid growth. Although the codel predicts density changes reasonably well over the range of temprature and fluence for which data are available, it does not predict any of the ificrostructural observations. This nucleation nechmisn, for exaple, requires a homgeneous void distribution, and the nucleation should be independent of the presence of hellun: neither of which ase obsurved experimentally. The odel predicte that the suclestion rate 
(and thus the vcid concentration) should increase with increasing temperature, reach a maxinum at approximately $425^{\circ} \mathrm{C}$ and then decrease at still higher temperatures: present results indicate that the void concentration decreases nootonically with increasing irradiation temperature. In a recent and revised version of the ndel (87), additional vacancy and interstitial sinks sere assumed and it now predicts that at a given Irradiation temperature the void concentration saturates if a fluence near $1 \times 10^{22}$ neutrons/cm and from that point on nearly all of the density change occurs as a result of void growth: the present results indicate that the vold oncentration continues to increase with increasing fluence and that the void growth rate decreases rapidly as a void grows. Purther, this molel predicts that the void concentration will be strongly dependent on the neutron flux: this was not observed in the present investigation.

On the basis of these arguments, it is concluded that none of the previousiy proposed vold nucleation mechanisus predoninate over a wide range of Irradiation conditions. Hang of the important experimental observations are consistent, however, with the concept that void nucleation occurs through the stabilization of vrid embryo by hellum atoms when the ebryo are below the critical aize for the prevailing vacancy supersaturation given by Fquation 41 . The manner in which heliu could Influence the vold oucleation process can be seen by considering the expression for the change in free energy per unit voluwe when a cavity of radius $R_{v}$, containing sone internal gas pressure $P_{8}$, grows by an anount $d R_{\mathbf{v}}$ : 


$$
\frac{d \Delta G_{v}}{4 \pi R_{v}^{2} d R_{v}}=\frac{2 Y}{R_{v}}-P_{g}-\frac{k T}{\Omega} \ln \frac{C_{v}}{C_{v 0}} .
$$

An internal gas pressure thus decreases the free energy change per unit volune for the addition of a vacancy to a vold enbrys and, for a given vacanc; supersaturation, the critical vold size ls decreased. In a simple case, this mechanisa involves the nucleation and grouth of hellu bubbles. Because of the availability of vacancies, it is reasonable to assure that the internal gas fressure in such bubbles is balanced by the surface energy term. Once the bubble has reached a critical size, given by

$$
R_{v}^{*}=\frac{2 Y}{P_{8}+\frac{k T}{\Omega} \ln \frac{C_{v}}{C_{v 0}}}
$$

it continues to grow due to the driving force provided by the vacancy supersaturation, thus beconing essentially "vold" in nacure rather than a hellum bubble.

If it is assuned that the vacancy supersaturation $\left(C_{v} / C_{v 0}\right)$ decreases as the Irradiation temperature is Increased ( 8.8 has been shown by calculations of Greenwood et al. (57) and Harkness and Lf (87)), several of the important experimental observations can be explained on the basis of hellum stabilization of void erbryo. At the beginning of Irradiation $(t=0)$ the nucleation rate 18 zero since ro hellu is present As Irradiation proceeds, the concentration of heliu Increases approxiastely linearly with fluence. The helium atow wil migrate 
through the lattice eventually colliding with other iselium atoms or being trapped at structural irregularities such as dislocations. Early in the irradiation (i.e., at low fast neutron fluences) the helium concentration will be low and the probability of collision of two helium atows or a single helium atom with a helium bubble of subcritical size w11 be sall. Under these conditions dislocations and other structural irregularities will gather helis anci enhanced diffusion along the dislocation core will assist in the formation of helium bubbles of the critical size. Thus, the first wids would form on dislocations. The tendency for volds which are located on dislocations to be elongated in the direction of the dislocation line could result if growth occurred by a mechanise proposed by Anelinckx et al. (88). The growth of a cavity located on a screw dislocation is envisioned to occur by the precipitation of vacencies along the steps produced at the ends of the cavity due to the displacenent caused by the dislocation. In such a case the steps wil wind into a spiral causing growth primarily along the direction of the dislocation line.

As the Irradiation progresses, the concentration of helium will continue to increase. As the helium diffuses through the lattice it w11 collide with other single hellum atoms or with helium bubbles. Given auficient time, bubbles of the critical size for the existing vacancy supersaturation will be formed. These bubbles could then continue to grow without the addition of hellum. This mechanism gives a nucleation rate-time behavior simllar to that expected due to transient nucleation proposed by Turnbull $(80)$; 1.e., Initially the nucleation 
rate is low because no crifical size nucle:. exist, as critical size nuciel begin to form the nucleation rate increases rapidly to a steady state value. The transient or incubation period prior to the onset of significant Ducleation would increase with increasing irradiation temperature since the lower vacancy supersaturation exisiting at the higher temperature would require larger critical size nuclei and thus longer times would be required for them to form.

1s the irradiation temerature is increased and the vacancy supersacuration decreases nucleation becones progressively wore difficult due to the increased critical size. At $: 70-630^{\circ} \mathrm{C}$ nearly all of the critical nuclel which form are thus on dislocstions or other preferred sites for helium precipitation. At st\$11 higher temperatures $\left(770-840^{\circ} \mathrm{C}\right)$ the vacancy supersaturation is small enough that heliw bubbles saller than 100 A dianeter do sot grow. The hellu stabilization of saall nuclel is consistent with the observation that the vold concentration In specimens which conteined helium prior to Irradiation was wach higher than that present in specimens which ald not contaln hellu.

Saturation of the vold concentration occurs when it becomes wre probable for a newly created helfu atom or for very small hellu bubbles to reach an existing vold as they diffuse through the lattice rather thai meet another gas atom or bubble and form a new stable nucleus.

Claudson et 로. (52) have examined several mechantsms of vold growth, each dependent upon a different set of liniting processes. Thrse mechanisms have time and neutron flux dependence which vary with the processes that control the net rate wit which vacancies are absorbed Into the volds. 
The complicating factor in attenpting to analyze the vold size data in terms of vold growth mechanisas is the observation that a vold, once nucleated, grows very rapidly but after a relatively short perfod of time the growth rate decreases sharply. This phenomenon causes an apparent maximu or limiting vold size which is dependent primarily on the irradiation temperature. The grouth rate as a function of time at low fluences cannot be deternined from the present experinental data and the growth eechanisn cannot be established.

In pure metals the occurrence of a maximun or linfting void size is not observed. Packan (47) and Farrell and King (90) have exanined high purity aluninu in which volds are observed at fluevces as low as $10^{19}$ neutrons $/ \mathrm{cm}^{2}$ (E > $\left.0.1 \mathrm{KeV}\right)$. Stiegler (70) and Bloco (46) have exanined nickel irradiated at fluences of $1.4 \times 10^{20}$ and $1 \times 10^{22}$ neutrons/ $\mathrm{Cm}^{2}(\mathrm{~B}>0.1 \mathrm{MeV})$ at a cenperature of approximately $475^{\circ} \mathrm{C}$. The naximan vold size for these two fluences was 225 and 1500 A respectively. Thus, In nickel the voids continue to grow, eventually resching sizes much larger than those observed in stainless steel irradiated at the same temperature or sane fraction of $T_{w}$. In addition, the vold growth rate In nickel corresponds to that expected from the diffusion-controlled precipitation of vacancies from a supersaturated solution:

$$
R_{v}=\left(2 D_{v} C_{v}\right)^{1 / 2}\left(t-t_{0}\right)^{1 / 2}
$$

whers $\left(t-t_{0}\right)$ is the time the vold has had to grow since nucleation. It is possible that a similar growth process occurs in stainless steel early to the life of a vold. The decreased growth rate appears to be 
peculiar tu stanless steel; or perhaps to alloys, since it is not observed in pure netals. The decreased growth rate does not appear to be due to a decrease in the vacancy supersaturation since void nucleation and growth of voids to the maximum size continues.

Stieglar et al. (91) have suggested that the decreased void growth rate may be caused by the formation of a shell of material around a vold In which the activation energy for vacancy notion is increased above that of the homgeneous alloy. Since a void grows by the net flow of vacancies toward the vold, atoms nust wo in the opposite direction. In an alloy, the region around the void will becone depleted of those components which have the highest diffusivities. This depletion form a shell of material in which the vacancy diffusivity 18 lorer, and for a given vacancy supersaturation the vold growth rate decreases. The concegc of solute segregation in vacancy gradients has been discussed by Anthony (92). For a two component alloy (solute B in solvent A), in which the diffusivity of solute B is lower then that of solvent A, solute enrichnent around vacancy sinks will occur due to the flux of vacancies into the sink. Ruczynski et al. (93) have detected this type of solute segregation in the inftial steges of two-wire sintering of homogeneous alloys of $\mathrm{Cu}-\mathrm{In}$ and $\mathrm{Cu}-\mathrm{Ag}_{\mathrm{g}}$.

In a complex alloy such as stainless steel segregation of those elements having lower diffusivities in the reglons around volds would be expected. Thus as a void grows a shall having a low vacancy diffusivity wil form around the vold and the growth rate will decrease. 
In a pure retal such as aluinum or nickel no solute is present and such segregation cannot occur. Gronth of volds in pure metals would thus continue, being linted only by other rate controlling processes. 
CRAPTER VII

concLOSIOUS

The nature of neutron irradiation damage in type 304 stainless steel has been deduced frea a study of nicrostructure and densicy changes in specinens irradiated in the temperature range $370-800^{\circ} \mathrm{C}$ to neutron fluences of $1 \times 10^{18}$ to $5 \times 10^{22}$ neutrons $/ c^{2}$ ( $\left.\mathrm{E}>0.1 \mathrm{keV}\right)$.

The eajor experimental observations were:

1. Defect clusters, which appear as all black dots when observed by transinission electron aicroscopy, are present in opectinens Irradiated to $1.4 \times 10^{20}$ neutrons $/ \mathrm{cm}^{2}$ (E > $0.1 \mathrm{keV}$ ). The concentration of these clusters decreased in specimens irradiated at progresaively hightr temperatures in the range 370 to $524^{\circ} \mathrm{C}$.

2. Specimens Irradiated in the temperature range 370 to $470^{\circ} \mathrm{C}$ and to neutron fluences in the range $2 \times 10^{21}$ to $5 \times 10^{22}$ neutrons/ca (E > $0.1 \mathrm{MeV}$ ) contafued volds and faulted interstitial dislocation 100ps.

3. After Irradiation at $570-630^{\circ} \mathrm{C}$ to $3.7 \times 10^{22}$ neutrons $/ \mathrm{cm}^{2}$ (E > $0.1 \mathrm{MeV}$ ) the danage structure consisted of a dislocation nework, a few unfaulted dislocation $100 p 8$ and volds.

4. The only danage observed after irradiation at $770-840^{\circ} \mathrm{C}$ to $3.7 \times 10^{22}$ neutrons/ $\mathrm{cm}^{2}$ ( $\mathrm{B}>0.1 \mathrm{keV}$ ) was hellu bubbles which were present both at grain boundaries and within the natrix.

5. After irradiation to lourt flvepces in the temperature range $370-470^{\circ} \mathrm{C}\left(1 . e .,>1 \times 10^{22}\right.$ neutrons $/ \mathrm{cm}^{2}$ ) or to $3.7 \times 10^{22}$ neutrons $/ \mathrm{cm}^{2}$ at $570-630^{\circ} \mathrm{C}$ the danage was nothonogeneous. 
6. For specimens irradiated to a constant neutron fluence the void soncentration decreased wonotonically with increasing irradiation temperature in the range 370 to $630^{\circ} \mathrm{C}$.

7. Heasurement of the maximu vold dianeter as a function of fluence (at constant irradiation temperature) showed that a given void gxors rapidly early in its life (i,e., at sall void sizes). A short tine after its formation the growth rate decreases sharply.

8. The microstructures of specimens which contained cyclotron infected hellim prior to their Irradiation showed heliu to have a pronounced influence on vold formation.

These experinental observations lead to the following ajor conclusions:

1. Void nucleation occurs by the stabilization of niclei by the hellu produced by $(n, \alpha)$ reactions.

2. The change in dislocation structure with increasing irradiation temperature (between 470 and $630^{\circ} \mathrm{C}$ ) is thought to be a result of the increase in stacking fault energy with increasing temperature.

3. The decreased void growth rate can be caused by the buildup of a shell around the void within which the vacancy diffusivity is lower than in a howgeneous alloy of the same average composition.

4. The density change, caused by the buildup of voids, is closely related to the void nucleation rate and has a fluence dependency wh1ch 18 temperature dependent. 


\section{LIST OF REFERENCES}




\section{LIST OF REFEREICES}

1. C. Carthorne and E. J. Fulton, "The Influence of Irradiation Tenperature on the Defect Structures in Stainless Steel," P. 446 in The Hature of Sall Defect Cluster, Vol. 2, Edited by M. J. Makin. Atonic EnergJ Research Establishment, Harwell, Report AERE-R5269, H. H. Stationary Office, London, 1966.

2. C. Carthorn $\geq$ and E. J. Pulton, "Voids in Irradiated Stzinless Steel," Lature 216, 515 (1967).

3. H. F. Whrphy and H. B. Stron, "Tube Burst Tests on Irradiated EBR-II Type 304L Stainless Steel Puel Cladding," Muclear Applications $\stackrel{4}{=} 222$ (1968).

4. F. Seltz, "On the Disordering of Sollds by Action of Fast Massive Particles," Disc. Faraday Soc. 5, 271 (1949).

5. B. T. Kelly, Irradiation Danage to Solids, Perganon Press, Ner York, 1966.

6. G. H. Kinchin and R. S. Pease, "The Displacement of Atoms in Solfds by Radiation," Rept. Progr. Phys. 18, 1 (1955).

7. G. J. Dienes and G. H. Vineyard, Radiation Effects in Sollds, Interscience, Hew York, 1957.

8. F. Seitz and J. Koehler, "Displacenent of Atoms During Irradiation," p. 305 in Solld State Physics, Vol. 2, Acadenic Press, Mer York, 1956.

9. J. R. Beeler, Jr., "Computer Studies of Neutron Irradiation and Annealing in Finite BCC Iron Specimens," p. 86 in Plow and Practure of Metals and Alloys in Muclear Enviroments, ASTH-STP-380, Am. Soc. Testing Vits., Philadelphia, Pa. (1965).

10. J. R. Beeler, Jr., "Pacancy and Interstitial Cluster Production in Neutron-Irradiation a-Iron," J. Applied Phys1c8, 37 (8), 3000 (1966).

11. J. A. Brinbanan, "On the Nature of Radiation Danage in Metals," J. Appl. Phys. 25, 961 (1954).

12. A. Seeger, "The Hature of Radlation Damage in Metals," p. 101 in Radiat1on Danage In Solids, Vo1. 1, Internatioual Atonic Bnergy Agency, Vienna, 1962 . 
13. .. O. Stiegler, K. Farre11, C. K. H. Dubose, and R. T. King, "High Fluence Heutron-Irradiation Dange in Aluninu," p. 215 in Radiation Danase in Reactor Katerials, Vol. 2, International Atonic Bnergo Agency, vienna, 1969.

14. H. E. Browaing and C. E. Miller, Jr., "Calculated Radiation-Induced Chapges in Thernocouple Conposition," p. 271 in Teperature, Its reasurement and Control in Science and Industry. Fol. 3, Reinhold, Rev York, 1962.

15. A. E. Cottrell, "Effects of Meutron Irradiation on Metals and Alloys," ket. Rev. 1, 479 (1956).

16. B. Pussell and I. J. Hastings, ".. Prelininary Investigation of Beliu Gas Precipitation in Irradiated Copper-Doron Allojs," J. Pucl. Mat1. 17, 30 (1965).

17. D. R. Harries, Meutron Irradiation Bhrittlenent of Amstenitic Stainless Steels and Hickel Base Allojs," J. Erit. Bucl. Bners: Soc. 5. 74 (1966).

18. E. E. Bloo and J. R. Weir, "Developent of Austenitsc Stainless Steels with Inproved Resistance to Elevated Temperature Irradiattion Dibrittlement," p. 261 in Irradiation Bffecte in Structural Haterials, ASTH-SIP-457, A. Soc. Testing Bits., Fhiladelphia, Pa. (1969).

19. A. F. Rowcliffe, G. J. C. Carpenter, H. F. Herrick and R. B. Mcholson, "An Electron Microscope Investigation of High-Temperature Burittlement of Irradiated Stainless Steels," p. 161 in Bffects of Irradiation on Structural Katerials, ASH-SIP-380, A. Soc. Testing Kats., Philadelphia, Pa. (1967).

20. G. J. C. Carpenter and R. B. Hcholson, "High-Tenperature Bbrittlewent of Het ils by Rare Gases," p. 383 in Radiatior Denage in Reactor Materials, Do1. 2, International Atonic Bnergo Agency, Vienna, 1969.

21. R. S. Barnes, "Bubrittlenent of Stainless Steels and Hickel-Based Allojs at High Temperature Induced by Neutron Irradiation," Nature 206, 1307 (1965).

22. J. R. Weir, Jr., "Radiation Danage at High Temperatures," Sclence 156 (3783) June 30, 1967.

23. H. Alter and C. E. Weber, "The Production of Hydrogen and Hellu in Metals During Neactcr Irradiation," J. Ducl. Materials 16, 68 (1965). 
24. A. DePino, Jr., "Helín Production by $(n, \alpha)$ Reactions in Stainless Steel," Huclear Applications $\underline{=}, 620$ (1967).

25. J. A. S1gler and D. Kuhlnann-W1sdorf, "Calculations on the Mechanical Bnergy of Vacancy Condensation Loops, Stacking Fault Tetrabedra, and Voids," Phys. Stat. Sol. 21, 545 (1967).

26. R. A. Johnson, "Calculations for the Stability of Voids, Stacking Fault Tetrahedra, and Dislocation Loops in Mickel," Phil. Mag. 16, 553 (1967).

27. J. Silcox and P. B. Hirsch, "Dislocation Loops in Neutron Irradiated Copper," Phil. Kag. 4, 1356 (1959).

28. R. S. Barnes and D. J. Masey, "The Hature of Radiation Induced Point

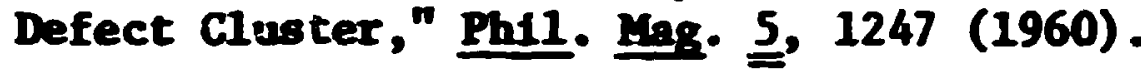

29. H. J. Makin, A. D. Whaphe, and F. J. Mnter, "Dislocation Loops and Hardenisg in Meutron Irradiated Copper," Phil. Mag. 6, 465 (1961).

30. H. J. Wakin, A. D. Whaphan, and F. J. Minter, "The Formation of Dislocation Locps in Copper During Heutron Irradiation," Phil. iag. ㄱ, 285 (1962).

31. T. J. Roppenaal, W. C. T. Yeh, and R. M. J. Cotteri11, "Lattice Defects in Neutron Irradiated Cu Solid Solutions," Phil. Mag. 12, 867 (1965).

32. K. L. Kerkle, "Radiation Induced Point Defect Clusters in Copper fend Gold," Phys. Status Solidi 18, 173 (1966).

33. K. G. McIntyre, "Interstitiai Dislocation Loops in Neutron Irradiated Copper," Phil. Mag. 15, 205 (1967):

34. R. G. McIntyre and L. M. Brown, "Diffraction Contrast from Smali Defect Clusters in irradiated Copper," p. 351 in the Nature of Sall Defect Clusters, Vol. 2, edited by M. J. Makin. Atomic EnergJ Research Bstellishnent, Harwell, Report ABRR-R5269. H. M. Stationary Office, London, 1966.

35. M. Wilkens and M. Bïhle, "Observations of Point Defect Agslomerations In Copper by Heans of Electron Microscopy," p. 365 in the Mature of Seal1 Defect Clusters, Vo1. 2, edited by M. J. Makin. Atowic Bnergy Research Establishment, Harwe11, Report AERE-R5269. H. H. Stationary Office, London, 1966. 
36. G. P. Scheidler, M. J. Makin, F. J. Minter, and W. F. Schilling, "The Effect of Irradiation Temperature on the Formation of Clusters in Neutron Irradiated Copper," p. 405 in The Mature of Sma11 Defect Clusters, Vol. 2, edited by M. J. Makin. Atonic Energy Research Establishment, Harwell, Report ARRB-R5269. H. M. Stationaty Cffice, London, 1966.

37. I. G. Greenfield and H. G. F. Wilsdorf, "Point Defect Clustering in Nickel," Proceedings of the International Conference on crystal Lattice Defects, Journal of the Physical Societ? of Japan 18, Supplement III (1963).

30. F. Be1l, "The Recovery of Cold-Worked and Neutron Irradiated Mickel in Stages III and IV," Acta. Met. 13, 363 (1965).

39. J. L. Brinhall, H. E. Kissinger, and B. Mastel, "Vacancy and Interstitial Clusters in Neutron-Irradiated Nickel," J. Appl. Phys. 37, 3317 (1966).

40. A. Bourrett and D. Dautreppe, "Study of Agglonerated Defects in Irradiated Pure Nickel by Electron Microscopy," Phys. Stat. Sol. 29, 283 (1968).

41. L. D. Hulett, Jr., T. O. Balduin, J. C. Crus, and F. H. Young, Jr., "The Effect of Neutrun Irradiation on Copper Crystals at High Temperatures," J. Appl. Phys. 39, 3945 (1968).

42. J. L. Brimhall and B. Mastel, "Voids in Neutron Irradiatei Pace Centered Cubic Metals," J. Nucl. Matl. 29, 123 (1969).

43. B. Mastel and J. L. Brimhall, "Voids Produced in High Purity Mickel by Neutron Irradiation," J. Nucl. Matl. 28, 115 (1968).

44. J. J. Holmes, "Irradiation Induced Swelling in Mickel Alloys," Trans. Am. Nucl. Soc. 12, 117 (1969).

45. G. L. Kulcinsk1, B. Mastel, and J. L. Brimhall, "Pornation of Veids in Iron During High Temperature Neutron Irradiation," Radiation Effects $\stackrel{2}{=} 57$ (1969).

46. B. B. Bloom and J. 0. Stiegler, "Comparison of Drfect Structures in Nickel and Stainless Steel After Irradiation at Interwediate Temperatures," Trans. Am. Nucl. Soc. 12, 116 (1969).

47. N. J. Packen, Oak R1dge National Laboratory, Oak Ridge, Tenn. Private cominication.

48. H. G. F. W11sdorf and D. Kuhlmann-W1ledori, "Dislocation Behavior In Quenched and Neutron Irradiated Stainjess Steel," J. Mucl. Mat1. $\underline{=}, 178$ (1962). 
49. J. S. Aretjo, J. R, Lor, Jr,, and V. E. Wolff, Radiation Effects on the Hechanical Properties of Microstructure of Iype 304 StainIeed Steel, USAEC Repcrt APED-4552, General Blectric Comany, Vallecitos Atonic Laboratory, Apri1 13, 1964.

50. B. B. Bloon, W. R. Martin, J. O. St1egler, J. R. Weir, "The Effect of Irradiation Tenperature on the Strength and Bicrostructure of Stainless Steel," J. llucl. Katl. 22, 68 (1967).

51. J. J. Holnes, R. E. Robbins, J. L. Brinhall, and B. Mastel, "Elevated Temerature Irradiation Hardening in Austenitic Stainless Steel," Acta Nst. 16, 955 (1968).

52. T. T. Claucos, J. J. Holmes, J. L. Straalsund, and H. R. Brager, "Fast-Reactor Radiation Induced Changes in Cladding and Structural Materials," p. 165 in Radiation Danage in Reactor iaterials, Vol. 2, International Atonic Energy Agency, Vienna, 1969.

53. J. O. Stiegler and E. E. Bloon, "The Effects of Large Fast-Heutron Fluences on the Structure of Stainless Steel," J. Mucl. Matl. 33, 173 (1969).

54. S. D. Harkness and Che-Yu L1, "A Yodel for Vold Fornation in Metals Irradiated in a Fast-Neutroú Environment," p. 189 in Radiation Deare in Reactor yuterials, Vo1. 2, International Atoafc Bnergy Asency, Vienna, 1969 .

55. J. J. Holnes, "Past Reactor Induced Swelling In Austenitic Stainless Stee1," J. Kucl. Yatl. 29, 241 (1969).

56. J. R. Beeler, JZ,, "Computer Experiments to Predict Radiation Effects in Reactor Materials," p. 3 in Radiation Danage in Reactor Haterials, Vol. 2, International Atonic Bnergy Agency, V1ema, 1969.

57. G. W. Greemood, A. J. E. Foreman, and D. E. RAmer, "The Role of Vacancies and Dislocations in the Bucleation and Grouth of Gas Bubbles in Irradiated Fissile Material," J. Nucl. Mat1. 4, 305 (1959).

58. W. A. Johnson and R. F. Mehl, "Reaction Kinetics in Processes of Nucleation and Growth," Irans. AIrE 135, 416 (1939).

59. T. Lauritzen, A. Withop, and U. Wolff, "irelling of Austenitic Stainless Steels Under Fast-Meutron Irradiation at Elevated Teaperatures," Muc1. Engr. and Des1 gn 9, 265 (1969).

60. E. E. Bloon and J. 0. Stiegler, "A Comparison of Irradiation Induced Swelling and Vold Bormation in Two Austenitic Stainless Steels," Accepted for publication in J. Hucl. Mntl. 
61. R. S. Nelsou and D. J. Kazey, "Void Foration In Stainless Steel During Charged-Particle Irradiation at Elevated Teoperatures," p. 157 in Radiation Damage in Reactor Materials, Vol. 2, Internatiozal Atonic Bnergy Agency, Viemna, 1969.

62. R. A. Cushnan, Argonne National Laboratory, Idsho Falls, Idaho. Private conumication.

63. C. R. H. DuBose and C. Jones, "Techniques for the Preparation of Transnission Electron Microscopy Specimens from Tubing," Netellography 2, 31 (1969).

64. J. H. Wood3, A. F. Zulliger, and E. E. Bloon, "Deternination of Nuclear Heating Rates in BBR-II," to be published.

65. R. T. King, "Cyclotron Simulation of Neutron Transmutation Produced Gases in Reactor Cladding and Structural Haterials," paper presented at International Conference on the Use of Oclotrons in Cheistry. Fetallurgy and Blolory, held at Oxford, Bngland, Sept. 1969. To be published in proceedings.

66. C. R. H. Dubose and J. O. Stiegler, Sentautonattc Preparation of Spectimens for Traneission Electron Hicroscopr, Oak Bddge Mational Laboratory Report 0wI-4066, Oak Ridge, Tem., Feb. 1967.

67. R. T. Ratcliffe, "The Measurenent of Swall Density Changes in Sollds," Brit. J. App1. Phys. 16, 1193 (1965).

68. J. L. Kamphouse, R. L. Stuart, and J. Hoteff, Theoretical Spectrur Threshold Detector Data Correlation in Ban-II, General Biectric Colpany, Huclear Systems Progran, Report Gap-720, Cincinnat1, Ohio, Sept., 1969.

69. M. Rühle, "Elestron Mfcroscopy of Swall Defect Clusters in Irradiated Hetals," Phys. Stat. Sol. 19, 263 (1967).

70. J. O. St1egler, Oak Ridge National Laboratory, Oak Ridge, Temn. Private commication.

71. L. R. Singhal and J. W. Martin, "The thucleation and Growth of Widaranstätten $\mathrm{M}_{23} \mathrm{Cu}$ Precipitation in an Austenitle Stafnleas Steel," Acta Yet. 16, 1159 (1968).

72. F. R. Beckitt and B. R. C1ark, "The Shape and Kechenten of Formtion of $\mathrm{H}_{23} \mathrm{C}_{6}$ Carbide in Austenite," Acte Het. 15, 113 (1967).

73. H. R. Brager and H. B. Kissinger, "Irradiation-Induced Precipitation in Type 316 Stainless Steel," Irans. … Hucl. Soc. 12 (1), 118 (1969). 
74. D. J. Hasey, A. Bowle, and R. S. Barnes, "On interstitial Dislocation Loops in Aluinu Bombarded vith Alpha-Particles," Phil. Mag. I, 1861 (1962).

75. B. Bdronson and G. R. H111amoon, "On the Deternination of the Lature of Dislocation Loops," Phil. Hag. 9, 277 (1964).

76. G. R. PlerCy and J. L. Witton, "Investigation of Radiation Danage in Pure Aluinu and Aluninu-17 Hagnesiun Alloy by Tranonission Blectron Microscopy," J. Inst. Hetals 90, 386 (1961).

77. A. H. Cottreil and B. A. BIIby, "Dislocation Theory of Ylelding and Strain 48ing of Iron," Proc. Phys. Soc. 62, 49 (1949).

78. J. Priedel, Dislocations, Pergan Press, Mea York, 1964.

79. H. Hu and S. R. Coodnan, "Cube Texture in Austenttic Stainless Steel," Irans. Het. Soc. A.I.H.B. 227, 1454 (1963).

80. H. G. Vanbueren, Inerfections in Crotals, P. 162, Jorth-Bolland Publishing Company, Ansterdan, 1961 .

81. H. Ipohorskt and H. S. Spring, "Blectron Radiation Dange in a High Voltage Blectron Mitcroscope," Phil. Has. 20, 937 (1969).

82. J. O. Stiegler and E. E. Bloom, Oak Ridge lational Lnberatory, Oak Ridge, Tem. Unpublished data.

83. K. Parrell and J. Houston, "Won-Randonly Distributed Irradiation Voids in Iron," subatted to J. Hecl. Mat1. for publication.

84. F. W. Mffen and J. O. Stiegler, Oak Ridge lational Laboratory, Oak Ridge, Tenn. Private commication.

85. J. O. Stiegler, K. Farrell, B. I. K. Wh, and H. E. HcCoy, Mature of Creep Cavities in Tungsten," Irans. ASA 60, 495 (1967).

86. D. Turnbull and J. C. Floher, "Rate of llucleation in Condensed System," J. Chen. Physe. 17, 71 (1949).

87. S. D. Harkness, J. A. Teak, C. Y. LI, "An Analysis of Past Heutron Effects on Vold Pormation and Creep in Hetelo," to be published.

88. 8. melinckx, W. Maenhout-VanberVorst, and W. Detsgser, "Cavity Formation in Hitrate-Doped Aivail Halldes," Acte yet. I, 8 (1959).

89. D. Turnbull, "Transient Hucleation," Trens. A.I.M.E. 175, 774 (1948).

90. R. Farrell and R. T. King, "supervolds in Irxadiated Muninum," Subntted to Phre. Stat. Sol. for publication. 
91. J. O. Stiegler, B. T. H. Loh, and B. B. Bloce, "The Developent of Concentration Gradients Around Volds in Irradiated Stainleas Steel," To be published.

92. T. R. Anthony, "Sriute Segregation in Vacancy Gradients Generated by Sintering end Temperature Changes," Acte Het. 17. 603 (1969).

93. G. C. Luczynski, G. Matsumur, and B. D. Cullity, "Segregation in Hoingeneous Alloys During Sintering," Acte Ket. 8, 209 (1960).

94. Guide for Irradiation Experiments in Bop-II, Argonne Hational Laboratory, Argone, Illinois, July, 1969 .

95. J. P. Bacce, R. V. Strain, C. L. Hejers, and S. T. Zesler, p. 73 in Argonne Rational Leboratory Reactor Developent Progreas Report. AI-7548, Argome Hational Leboratory, Argome, Illino1s, January, 1969.

96. J. Woteff, University of Cincimati, Cincimati, Chio. Private comminication. 


\section{APPEDIX A}

\section{DESCRIPTIOA OF BXPERTIETTAL BREEDER REACTOR-II}

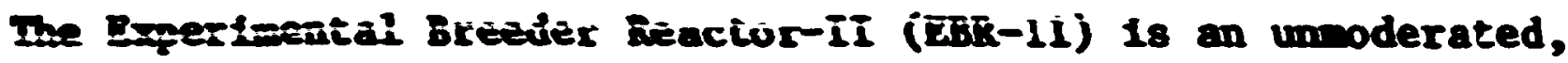
sodiu cooled reactor with a full power design rating of $62.5 \mathrm{kw}$ (th). The reactor assembly consists of 637 subassemblies spaced on a triangular pitch of $2.320 \mathrm{in}$. The present nowinal core loading consists of 77 (total) eariched-uraniun driver and experinental irradiation subassemblies, two safety rods, and 12 control rod subassemblies. The imer blanket contains 36 natural uraniv and experimental subassemblies and the outer blanket contains 510 natural uraniun subassemblies. A typlcal loadicī diagran for the elght inner row of the reactor (the reactor core consists of the imer six rows) is shown in Pigure 53. All of the nate:1als discussed in this report were irradiated in row 2, 3, or 4 of the reactor core. Flux and fluence calculations were based prinarily on the dosinetry and spectrun calculations of Rauphouse et a1. (68), and on Infornation taken from the Guide for Irradiation Experiments In BBR-II (94). The experimentally deternined value of the neutron flux at the Dow 2 addplane $182.1 \times 10^{15}$ neutrons/cm (total) (68). Using this value of flux, and the dosinetry results and spectru calculations of Kamptonuse et al., the neutron flux as a function of axtal distance from the midplane for Row 2 was obtained as shown in P1gure 54. This graph was used to calculate the fluences recelved by specinens irradiated in Subassembly $X-0-34$. For the EBR-II driver fuel cladding (driver fuel element (-179-8r) and the safety rod thimble (safety rod thimble 3-D-1 


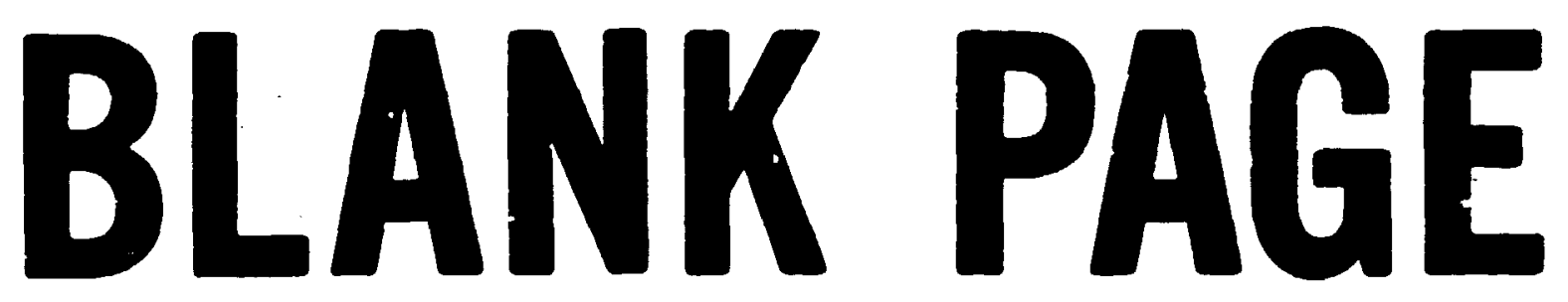




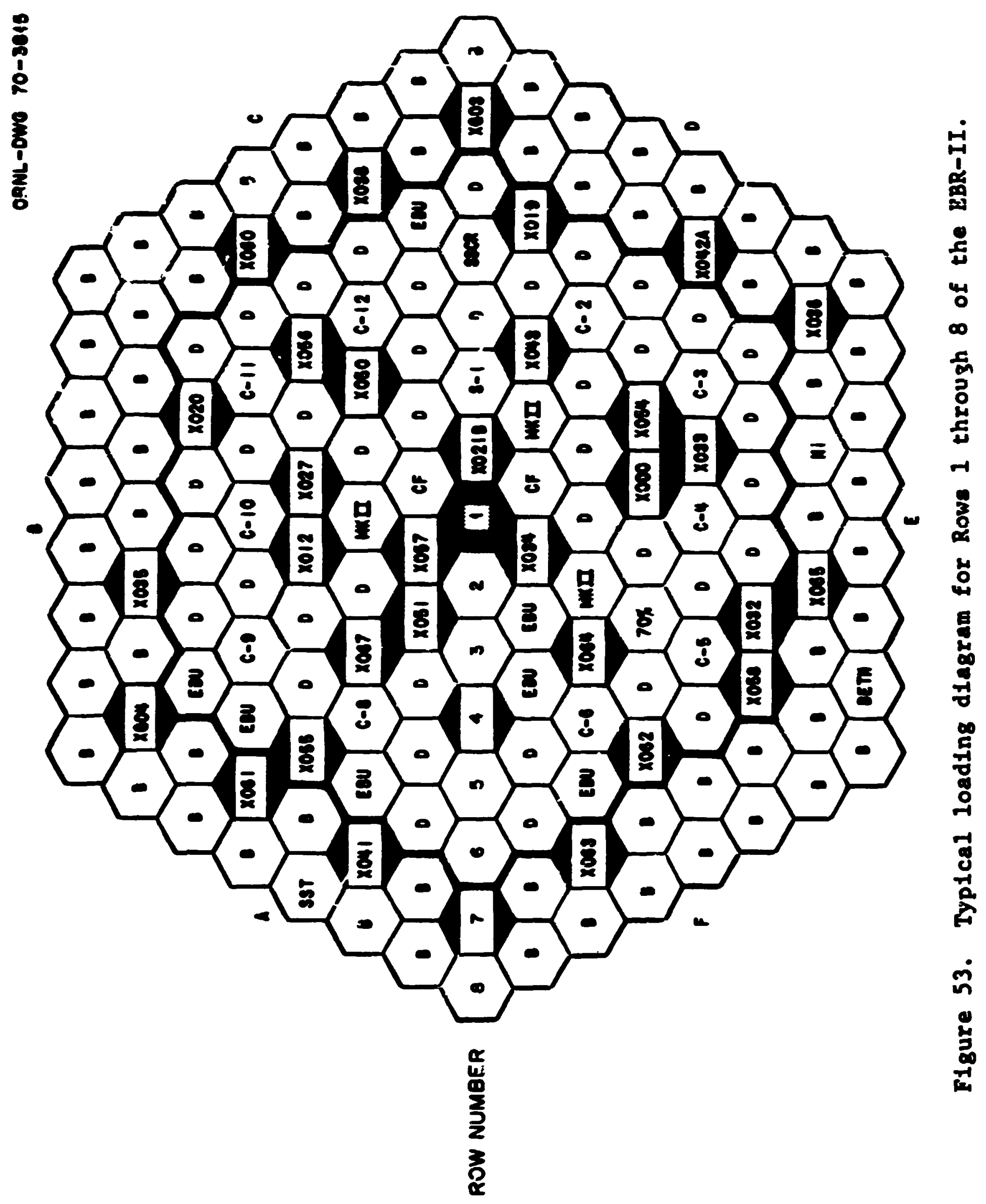




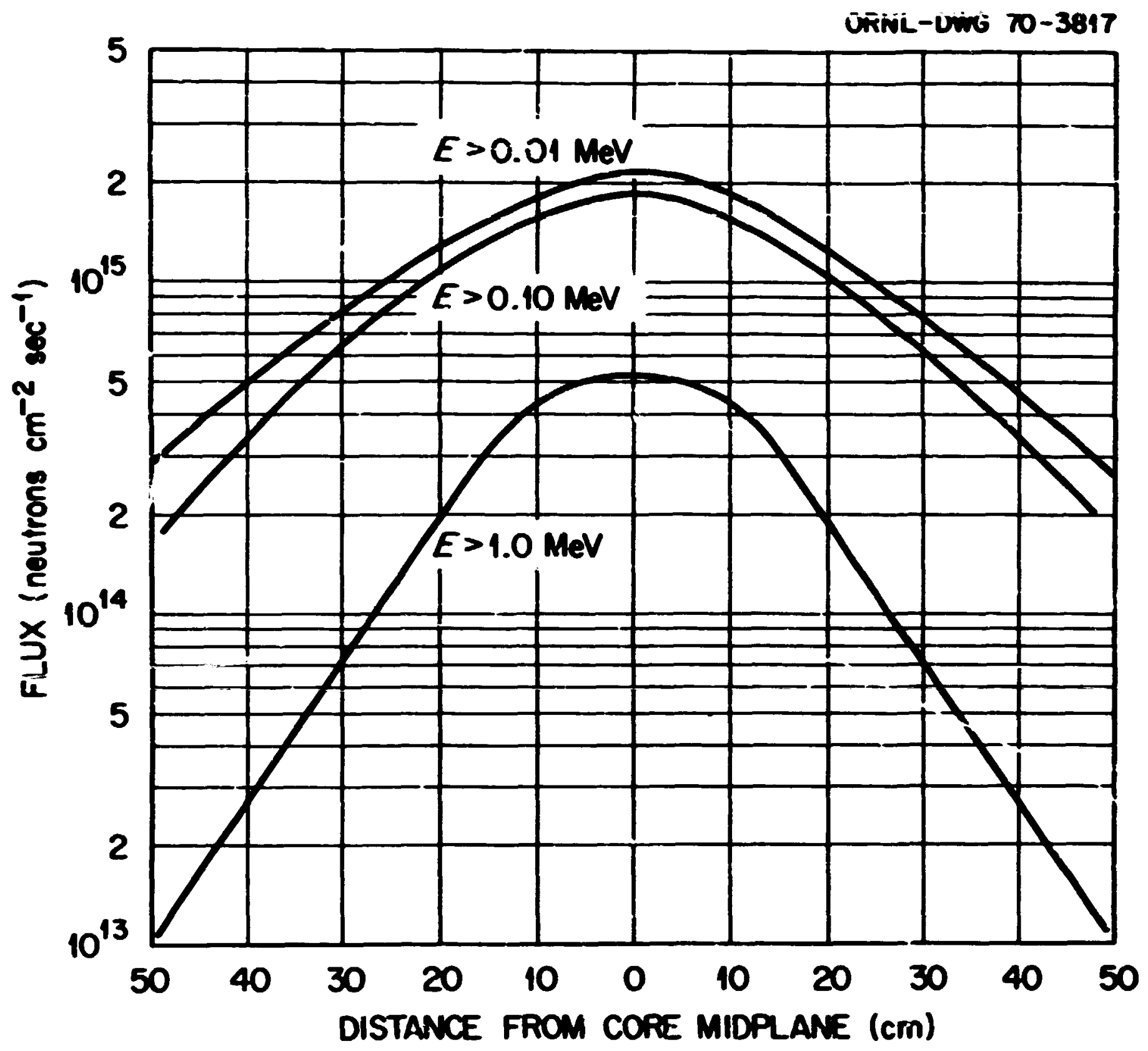

Pigure 54. Heutron flux as a function of distance fron the reactor afdplane in Row 2 of the BBR-II. 
flat C) the flueace at the reactor aidplane was supplied by Argonne National Laboratory $(62,95)$ and the distribution of the neutron fluence as a function of axdal distance from the aidplane was assured to be the sane as shown in Figure 54.

The neutron fluences for the shroud tube which was irradiated in Subassembly ICO5, Bow 4, were calculated by Hoteff (96) and were shown in Pigure 13, page 49. 


\section{APPEIDIX B}

MRASURERTIT OF VOID COACEITRATIOA

The deternination of void concentration was accomplished by measuring the foll thickness by steronicroscopy and then counting the nuber of volds in the save area of the photonicrograph. The vold concentration, $P_{v}$, is then given by:

$$
p_{v}=\frac{N_{v} y^{3}}{\Delta t}
$$

where $M_{v}$ is the number of volds counted in area $A, t$ is the thichess of the foll as deternined from the sterculcrographs, and $H$ is the agnification. The deternination of void concentration is thus subject to the errors involved in measuring $t$ and $M$.

The accuracy of this deternination was estinated by meacuring the void concentration in two different aress of one foll and in one aren of a second foll. These folls were both removed fron the sane axial posttion of the BBR-II shroud tube and thus composition and Irradiation conditions were essentially identical. The foil thickness was deternined at a point in the photonicrograph and the number of volds in $25 \mathrm{~cm}^{2}$ arews near this thickness wessurement was counted.

The results are listed in Table VII. It is apparent that the variation in vold concentration within the sowe grain is sall wa can be seen from the saple standard deviations. A larger variation in vold concentration was observed from one eample to enother. The source of 
TABLE VII

VOID CONCENTRATION DATA FOR FOILS 1 AND 2 OF IRRADIATED SPECIMEAN S-3

\begin{tabular}{|c|c|c|c|c|c|}
\hline $\begin{array}{l}\text { Sample } \\
\text { Number }\end{array}$ & $\begin{array}{c}\text { Poil } \\
\text { Th1 ckneses } \\
\text { A }\end{array}$ & $\begin{array}{l}\text { Number } \\
\text { of Volds } \\
\text { in } 25 \mathrm{~cm}^{2}\end{array}$ & $\begin{array}{c}\text { Vold } \\
\text { Concentration } \\
\text { Volda } / \mathrm{cm}^{3} \\
P_{v}\end{array}$ & $\begin{array}{c}\text { Mean Vold } \\
\text { Concentration } \\
\bar{\Gamma}_{v}\end{array}$ & $\begin{array}{l}\text { Sample } \\
\text { Standard } \\
\text { Deviation }\end{array}$ \\
\hline$S-3-1-A$ & 900 & $\begin{array}{l}174 \\
165 \\
171 \\
168\end{array}$ & $\begin{array}{l}9.78 \times 10^{15} \\
9.28 \times 10^{15} \\
9.62 \times 10^{15} \\
9.45 \times 10^{15}\end{array}$ & $9.53 \times 10^{15}$ & $0.19 \times 10^{15}$ \\
\hline $5-3-1-8$ & 1250 & $\begin{array}{l}165 \\
170 \\
158\end{array}$ & $\begin{array}{l}6.68 \times 10^{15} \\
6.69 \times 10^{15} \\
6.43 \times 10^{15}\end{array}$ & $6.60 \times 10^{15}$ & $0.16 \times 10^{15}$ \\
\hline$s-3-2-A$ & 850 & $\begin{array}{l}116 \\
118 \\
117 \\
113 \\
119\end{array}$ & $\begin{array}{l}6.91 \times 10^{15} \\
7.03 \times 10^{15} \\
6.97 \times 10^{15} \\
6.73 \times 10^{15} \\
7.09 \times 10^{15}\end{array}$ & $6.95 \times 10^{15}$ & $0.12 \times 10^{15}$ \\
\hline
\end{tabular}


this varlation does not appear to be the foll itself since the lergest dj.fference in void concentration was observed in two different areas of the same foil (1.e., sample 5-3-1-A and 5-3-1-B). Measurement of relative vold concentrations in two different grains visible on the sane phozoncrograph exhibited variations of approxdmately the same magnitude as those neasured within a given saple as listed in Table VII. The variation in measured vold concentration thus appears to be due prinarily to errors assoclated with deternination of the foll thickness and aagnification.

The mean void concentration for these three saples was $7.69 \times$ $10^{15} \mathrm{volds} / \mathrm{cm}^{3}$. The standard deviation of the seasurement was $1.3 \times 10^{15}$ volds/ca ${ }^{3}$ (approximately $16 z$ of the mean value). 